
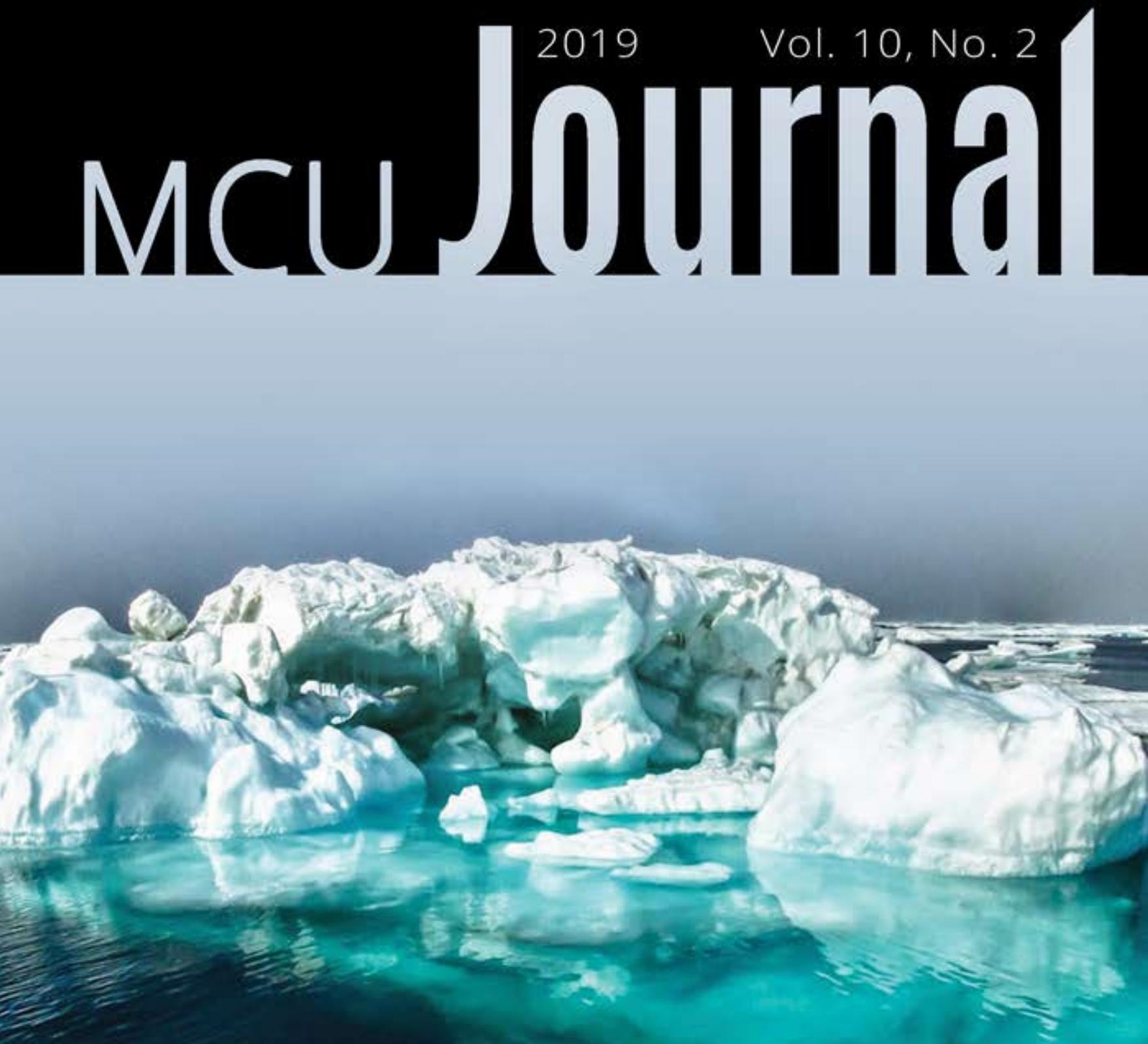

Published by Marine Corps University Press 


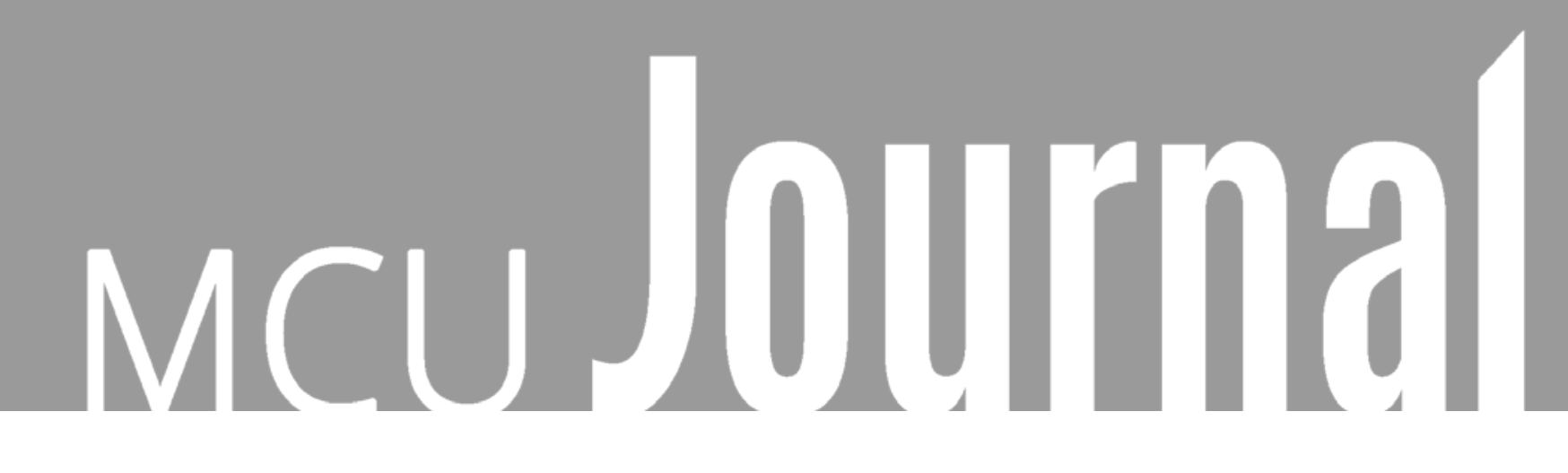

\section{MCUP}

Published by Marine Corps University Press 2044 Broadway Street I Quantico, VA 22134 
MARINE CORPS UNIVERSITY

BGen Jay M. Bargeron, USMC

President

Col Gregory L. Lemons, USMC

Chief of Staff

Dr. Edward T. Nevgloski

Director, Marine Corps History Division and Gray Research Center

Mr. Paul J. Weber

Deputy Director, Marine Corps History

Division and Gray Research Center

\section{EDITORIAL STAFF}

Ms. Angela J. Anderson

Senior Editor

Mr. Jason Gosnell

Managing Editor

Ms. Stephani L. Miller

Manuscript Editor

Mr. Christopher Blaker

Manuscript Editor

EDITORIAL BOARD

Dr. Rebecca Johnson

Vice President, Academic Affairs, MCU

Dr. James H. Joyner Jr.

Associate Professor of Strategic Studies

Command and Staff College, MCU

Dr. Benjamin P. Nickels

Academic Chair for Transnational Threats and Counterterrorism

Africa Center for Strategic Studies, NDU

Dr. Christopher S. Stowe

Professor of Military History and

Head, War Studies Department,

Command and Staff College, MCU

Dr. Paolo Tripodi

Head, Ethics Branch

Lejeune Leadership Institute, MCU

Dr. Christopher D. Yung

Donald Bren Chair of Non-Western

Strategic Thought, MCU

Dr. Earl J. Catagnus

Director, H.R. McMaster Center

for Security Studies,

Valley Forge Military College

Dr. Jordan Malfoy

Digital Historian

Marine Corps History Division, MCU

ADVISORY BOARD

Col Mary H. Reinwald, USMC (Ret)

Editor, Leatherneck Magazine

Col Christopher Woodbridge, USMC (Ret)

Editor, Marine Corps Gazette

Col Jon Sachrison, USMC (Ret)

COO, Marine Corps University Foundation

MCU Journal

(Print) ISSN 2164-4209

(Online) ISSN 2164-4217
Established in 2008, MCU Press recognizes the importance of an open dialogue between scholars, policy makers, analysts, and military leaders and of crossing civilian-military boundaries to advance knowledge and solve problems. To that end, MCUP launched the Marine Corps University Journal (MCU Journal) in 2010 to provide a forum for interdisciplinary discussion of national security and international relations issues and how they have an impact on the Department of Defense, the Department of the Navy, and the U.S. Marine Corps directly and indirectly. The MCU Journal is published biannually, with occasional special issues that highlight key topics of interest.

\section{ARTICLE SUBMISSIONS}

The editors are looking for academic articles in the areas of international relations, geopolitical issues, national security and policy, and cybersecurity. To submit an article or to learn more about our submission guidelines, please email MCU_Press@usmcu.edu.

\section{BOOK REVIEWS}

Send an email with a brief description of your interests to MCU_Press@usmcu.edu.

\section{SUBSCRIPTIONS}

Subscriptions to MCU Journal are free. To join our subscription list or to obtain back issues of the journal, send your mailing address to MCU_Press@usmcu.edu.

\section{ADDRESS CHANGE}

Send address updates to MCU_Press@usmcu.edu to maintain uninterrupted delivery.

\section{INDEXING}

The journal is indexed by EBSCO, ProQuest, OCLC ArticleFirst, Defense Technical Information Center (DTIC), JournalSeek, IBZ Online, British Library System, Lancaster Index to Defense and International Security Literature, and AU Library Index to Military Periodicals.

\section{DISCLAIMER}

The views expressed in the articles and reviews in this journal are solely those of the authors. They do not necessarily reflect the opinions of the organizations for which they work, Marine Corps University, the U.S. Marine Corps, the Department of the Navy, or the U.S. government. When necessary, errata will be published immediately following the book reviews.

The production of this journal and other MCUP products graciously supported by the Marine Corps University Foundation. 
From the Editors

\section{GREAT POWER COMPETION}

Innovation and Historical Continuity

in Great Power Competition

Christopher C. Harmon, PhD

The Amphibious Imperative of the French and Indian War

T. J. Linzy, PhD

The Ottomans, Britain, Sectarianism, and the Sudanese Army: 46 1899-2019

Jack Vahram Kalpakian, PhD

The Expeditionary Implications of a Populist Grand Strategy

60

Bruce I. Gudmundsson, PhD

The American Polar Pivot: Gaining a Comparative Advantage in Great Power Competition

Ryan Burke, PhD; and Major Jahara Matisek, U.S. Air Force, PhD

Defense and Deterrence on NATO's Northern Flank:

Strengthening the U.S. Marine Corps' Role in Europe

Zsofia Budai

A Case for Sino-American Cooperation

Against Climate Change

Kevin Johnston 
Russia's Information Warfare:

Exploring the Cognitive Dimension

Blagovest Tashev, PhD; Lieutenant Colonel Michael Purcell (Ret);

and Major Brian McLaughlin (Ret)

Prescribing an American Grand Strategy for the Era

of Renewed Great Power Competition

Kashish Parpiani

Competing through Cooperation: Leveraging Security

Cooperation to Counter Chinese and Russian Influence in Africa

Captain Daniel De Wit, U.S. Marine Corps Reserve

U.S. Strategic Interests in the Arctic: A Proposed Department of Defense Approach

Major Timothy W. Chess, U.S. Army

\section{REVIEW ESSAYS}

The Weaponization of Information: Social Media, Commercia 185

Search, and the Changing Character of War

Captain Daniel J. Vigeant, U.S. Army

A Riddle Unwrapped: North Korea and the World

Leo J. Daugherty III, PhD

\section{BOOK REVIEWS}

Exceptional America: What Divides Americans from the World and from Each Other by Mugambi Jouet

Reviewed by Tim Lacy, PhD

loutou: Kokusaku ni Honrō Sareta 130 Nen (Iwo Jima: 130 Years at the Mercy of National Policy) by Ishihara Shun Reviewed by Robert D. Eldridge, PhD

American Power \& Liberal Order: A Conservative Internationalist Grand Strategy by Paul D. Miller

Reviewed by Kashish Parpiani

All Measures Short of War: The Contest for the 21st Century and the Future of American Power by Thomas J. Wright Reviewed by Frank X. Kozlowski 
Coercion: The Power to Hurt in International Politics

206

edited by Kelly M. Greenhill and Peter Krause

Reviewed by John Sislin, PhD

Confronting Torture: Essays on the Ethics, Legality, History,

211

and Psychology of Torture Today edited by Scott A. Anderson

and Martha C. Nussbaum

Reviewed by Christopher C. Harmon, PhD

Dare to Lead: Brave Work, Tough Conversations, Whole Hearts

by Brené Brown

Reviewed by Lieutenant Colonel Richard A. McConnell (Ret)

How NATO Adapts: Strategy and Organization in the Atlantic

Alliance since 1950 by Seth A. Johnston

Reviewed by James $\mathrm{H}$. Joyner Jr., PhD

State-Building in Kazakhstan: Continuity and Transformation

of Informal Institutions by Dina Sharipova

Reviewed by Keith D. Dickson, PhD

Strategic Challenges in the Baltic Sea Region: Russia, Deterrence, and Reassurance edited by Ann-Sofie Dahl

Reviewed by James Lockhart, PhD 



\section{From the Editors}

In this issue of $M C U$ Journal, the authors discuss various concepts of power and great power competition. For generations, scholars have debated changes in power and how that evolution could potentially impact the United States, its allies, and those hovering on the edge of greatness in whatever form that may take. The concept of power has taken on many meanings as the character of warfare has adapted to the time- - hard power, soft power, sea power, airpower, space power, great power, combat power, etc. So how do we define such an abstract concept as power? The Department of Defense (DOD) defines combat power as "the total means of destructive and/or disruptive force which a military unit/formation can apply against the opponent at a given time." Clearly, power must be projected; and for our purposes, that means an entity has the "ability ... to apply all or some of its elements of national power-political, economic, informational, or military — to rapidly and effectively deploy and sustain forces in and from multiple dispersed locations to respond to crises, to contribute to deterrence, and to enhance regional stability." 1

We would be remiss in our discussion, of course, to ignore the thoughts of early military theorists. In Carl von Clausewitz's consideration of war, he defined power as "the sum of available means and the strength of the will." Alfred Thayer Mahan would approach the concept of power as the means by which a nation extends its military power onto the seas. Measured in terms of a nation's capacity to use the seas in defiance of rivals and competitors, seapower includes diverse elements, such as combat craft and weapons, auxiliary craft, commercial shipping, bases, and trained personnel. ${ }^{3}$ While these approaches to power rely primarily on military might as you would see with hard power, newer conventions such as soft power focus on international relations, typically involving economic or cultural influence, to achieve the defined goal. ${ }^{4}$ As you will see with this issue of $M C U$ Journal, these are but a few of the many discussions to be had on the larger concepts of power.

For example, great power competition can take many forms and has occurred throughout history, as evidenced by Christopher Harmon's overview 
of great power competition, encompassing such diverse areas as geopolitics, strategic culture, ideologies, and coalitions and alliances. The great power competition between Carthage and Rome is but one example of an ancient great power competition presented by Harmon as evidence of the historical struggle between great powers to maintain hegemony and great power status. From historical European great power competition spanning continents, to today's rapidly changing environment of great power competition with new threats and opportunities, it is a constantly evolving conception of what constitutes power in each new age of technological advancement. The great power struggle between France and Great Britain over control of North America is examined in T. J. Linzy's article "The Amphibious Imperative of the French and Indian War." Here, Linzy analyzes the unique strategies that both Britain and France had to employ during the French and Indian War. The ability to adapt to new technologies and strategies is one of the hallmarks of maintaining great power status.

Adaptability is one of the main themes that run throughout these diverse articles on great power competition. In Bruce I. Gudmundsson's article "The Expeditionary Implications of a Populist Grand Strategy," Gudmundsson proposes a realignment in strategic interests due to the rising populism found in many modern nation-states. This would involve an adjustment in missions from changing governments or beliefs of peoples as a reflection of liberal democracy, to an American focus on short interventions that do not attempt to alter the dominant culture of the region.

Technology and information warfare represent other facets of great power competition that constantly change the way nation-states use strategies to expand their influence in the world. Exemplifying this newfound global reach, we assess Russia's meddling in the 2016 U.S. presidential elections as a brand of information warfare. While the Russians have become adept at using this technique in previous conflicts with George and Ukraine, America recognizes its effectiveness through disinformation campaigns in the United States. As Tashev et al. state in the article "Russia's Information Campaign: Exploring the Cognitive Dimension," the "trend is facilitated by the proliferation of technologies and the growing use of the internet and social media." These communication changes amplified the effects of information campaigns - or information warfare as it is commonly called. Technology has enabled unmanned drones to patrol skies continents away from their home country, while cyberattacks can disrupt a country's defense and infrastructure from the safety of an office a world away.

Another newly emerging threat relevant to the changing nature of great power competition is increased competition in the Arctic and Antarctic. This involves an increasingly aggressive Russian posture toward the Arctic, coupled with the effects of climate change and what that entails for navigation routes, 
the location of bases, and extraction of resources in formerly frozen and lifeless landscapes in the poles. The role of climate change in creating new arenas of great power competition is a continuing theme in this issue. Icecaps melting, as discussed in "The American Polar Pivot: Gaining Advantage in Great Power Competition," by Ryan Burke and Jahara Matisek, presents new opportunities for expanding global influence for polar-oriented nations. Russia is rapidly expanding its presence in the Arctic, while the United States races to reopen abandoned Cold War-era Arctic bases or to create new fleets of icebreakers to compete with Russia's expanding fleet. The authors advocate an American polar pivot to counter the emerging Russian threat, particularly with the Russian Federation's construction of new polar bases and the construction of a fleet of icebreakers as well as the Chinese development of its first nuclear-powered icebreaker. They argue that America must pivot its focus to navigate and defend interests in the increasingly militarized Arctic and Antarctic, maintaining that America must be at the forefront of defending new routes of navigation due to melting icecaps.

Great power competition could also foster cooperation against common threats. For example, climate change as an emerging threat to great power status is addressed in depth in Kevin Johnston's article, which advocates cooperation among great powers, specifically China and the United States, to counteract the worldwide effects of climate change. This is especially important for the Department of Defense, as many bases are near areas subject to flooding, coastal erosion, and extreme weather events. Climate change is a global threat that could dramatically shift great power arrangements in ways yet seen in the history of our planet. Aside from the physical and financial damage caused by these increasingly unpredictable extreme weather events that impact national security, the Department of Defense will also need to upgrade its current facilities to withstand damage during these events - at great cost.

A variety of strategies have been adopted by our adversaries to challenge America's role as the world's sole superpower. As Daniel De Witt explains in his article "Competing through Competition: Leveraging Security Competition to Counter Chinese and Russian Influence in Africa," these tactics include China's incentive-based system of buying alliances through infrastructure improvement in countries across the world, while Russia remains content to challenge America and its allies through proxy, frozen conflicts throughout the world, thus destabilizing America and its allies.

America must find its own way in this newly emerging world order of great power competition by adopting innovative solutions to secure global peace and democracy. There are many solutions to some of the emerging threats the United States will face in the future found in this volume of $M C U$ Journal. Some of the solutions offered come from adversaries' adoption of new strategies in the 
face of a changing world. As Sun Tzu once said: "If you know the enemy and know yourself, you need not fear the result of a hundred battles. If you know yourself but not the enemy, for every victory gained you will also suffer a defeat. If you know neither the enemy nor yourself, you will succumb in every battle."5

The remainder of the journal rounds out with a selection of review essays and book reviews that continues our focus on great power competition but also highlights continuing challenges in national security and international relations. The coming year will be busy for the MCU Journal editors as we work to provide issues on a diverse range of topics relevant to the study of militaries and defense. The upcoming Spring 2020 issue offers a diverse presentation of innovation and the changing character warfare, particularly plans and theories for future warfare, the potential or planned advances in technology, how the Services envision or plan for it, and key nation-states' future war strategies. We look forward to hearing your thoughts on these topics and to your future participation. Join the conversation on the MC UPress Facebook and MC_U Press Twitter pages or communicate with us via email at MCU_Press@usmcu.edu.

\section{Notes}

1. Department of Defense Dictionary of Military and Associated Terms (Washington, DC: Department of Defense, 2019).

2. Carl von Clausewitz, On War, ed. Michael Howard and Peter Paret (Princeton, NJ: Princeton University Press, 1976), chapter 1.

3. Capt A. T. Mahan, Influence of Sea Power upon History, 1660-1783 (Boston, MA: Little, Brown, 1890).

4. Colin S. Gray, Hard Power and Soft Power: The Utility of Military Force as an Instrument of Policy in the 21st Century (Carlisle, PA: Strategic Studies Institute, U.S. Army War College, 2011); and Joseph S. Nye Jr., "Soft Power," Foreign Policy, no. 80 (Autumn 1990), 153-71, https://doi.org/10.2307/1148580.

5. Sun Tzu, The Art of War, trans. Lionel Giles (New York: Cosimo Classics), 11. 


\title{
Innovation and Historical Continuity in Great Power Competition
}

\author{
Christopher C. Harmon, PhD
}

\begin{abstract}
Even in this age of remarkable changes, the character of warfare and the continuities of geography and politics are weighty and instructive. Politicians and strategists often relearn the most fundamental lessons about these continuities. It is thus no surprise that the current security establishment in China is infatuated with the writings of Alfred Thayer Mahan, the American naval power theorist who died in 1914 .
\end{abstract}

Keywords: patterns, strategy, geography, nature of warfare, character of warfare, naval, China

con

n 2005, years before the Pentagon would declare this an era of great power competition, two experts on maritime power published a remarkable article in the journal Comparative Strategy. It declared in effect that Chinese strategists have become obsessed with Alfred Thayer Mahan. ${ }^{1}$ Those authors, Toshi Yoshihara and James Holmes, then released a lengthy study, Red Star over the Pacific, that evidenced widespread enthusiasm in top security circles in the People's Republic of China (PRC) for a seapower theorist the Communists had long criticized, the American "imperialist” A. T. Mahan, whose line of important books appeared in the years before World War I. ${ }^{2}$ In their second edition in 2018, Holmes and Yoshihara held to their position. This reaching Chinese

Christopher C. Harmon holds the Bren Chair of Great Power Competition with the Marine Corps University and its foundation. He taught strategy and policy at the U.S. Naval War College, worked for a member of the House Armed Services Committee, served as lead author or editor of six books, and has written for the geopolitics journal Orbis. For reviews of the manuscript, the author is grateful to Charles Robert Harmon and to Sara Wood and Ian Brown of Marine Corps University's Brute Krulak Center for Innovation and Creativity. 
interest in the American historical figure Mahan is very sensible, given what China is today and what it wishes to become.

New interest in one theorist may be read as part of an ongoing flood of data on China's economic expansion, growing foreign commerce, and warship construction. Certainly, China has been transitioning from a continental power to a new self-understanding as a mixed power with expansive maritime interests. And this Chinese appreciation for Mahan's work is also a reminder-which is needed on occasion amid our hyper-technological world — of the many things that do not change about security and war. Military history, wisdom about politics, and patterns in strategies may age, to be sure, but that which is old may well be more valuable than ever. Yet, another line of thought is sparked by the news of the Chinese study of old American military theories: the United States should be more deeply in thought on these matters of great power rivalry. How well does the United States know its own classics?

A. T. Mahan was no celebrated author among his American compatriots initially, as he began to publish profound books and essays. He became a celebrity in England, where people had studied seapower longer and more seriously than the Americans had. He was famous "over there" first, and the United States soon saw why. Paradoxically, today it is Americans that may need a reminder of how power is created and defended. Washington should waste no time resenting the skill the Chinese government is showing in quietly acquiring anchorages, resource bases, and communications sites abroad. Some such business is legal, and most of it is simply smart. ${ }^{3}$ For the United States, the challenge is to outthink and outperform this increasingly confident rival.

In that spirit, no member of our Senate or staffer-officer in our Department of Defense can think they are wasting the few hours or days given over to a book by Mahan. In a notable turn of events, we could say that for public servants living in Washington, DC, rereading Mahan and "looking outward" may qualify these days as "opposition research."

This article argues, in a line A. T. Mahan might appreciate, that the nature of warfare is unchanging and that:

Essential works of theory may come into renewed validity.

Patterns in strategy are not numerous and thus have a way of coming back in some form or another. ${ }^{4}$

Grand strategy — and military strategies — involve both art and science, and as such must be studied and practiced.

On this, world history is a storehouse of intellectual wealth.

Geography sets fundamental boundaries that must be understood and used well. 
All of the above are among the fundamentals that each new age neglects, reconsiders, or confronts. They are always there, no matter if the year is 1910 or 2020. As the United States asks what is new in this epoch of great power competition, Americans would do well to grapple closely with the fundamentals and not be too distracted by the newest weapon, the strangest event, or the most recent experiment in space.

\section{Geography and Strategic Culture}

Like human nature, geography is a foundation for fresh thinking about national needs and strategic options. Mahan's book The Problem of Asia was published in 1900, but it thinks through some of the same questions that would face Secretary of State Hillary Clinton and President Barack H. Obama when they indicated a "rebalance" toward Asia. ${ }^{5}$ The weight of population, the extent of territory for Russia and China, the promise of commercial markets, and the prospects of threats from Asia all were of close interest to our seminal theorist of seapower. Mahan lobbied for, and almost lived long enough to see, a completed Panama Canal. The new canal significantly enhanced access to Asian markets, improved the geographical position of the United States, and opened new possibilities in American defense planning.

In world history, the rare cases of slicing through an isthmus to alter something as immutable as geography can make a difference in war. Crises punctuated the years leading into 1914, but Germany's top admiral, Alfred von Tirpitz, did not want to begin a war until Germany had completed the widening of the Kiel Canal, allowing its High Seas Fleet to pass more safely between the North and Baltic Seas at any convenient time. ${ }^{6}$ This emphasized the importance of geography in national defense. Mahan had already seen that in peace (not only war), national strategy would be beautifully served by the opening of a Central American canal. Today, of course, he would grind his teeth at how the United States chose to give up control thereof.

Now, as Merchant Marine expert Larry Cosgriff observes, China has been slowly accumulating judicious purchases and long-term leases on both oceanfronts served by the Panama Canal. ${ }^{7}$ The business interests and permanent installations mean intelligence collection. They also facilitate a great increase in the kinds of trade that serve a mercantile economy, such as China. Trade power can pay for military power, as Mahan taught, and the mainland Chinese have moved quickly and smoothly along those two parallel paths. These acquisitions in the canal zone are a local illustration, within our hemisphere, of Beijing's world-spanning effort to cinch together a belt of roads, trading posts, and harbors. 


\section{Geopolitics}

Geopolitics and strategic culture are phenomena closely related to the hard lines of physical geography. The first had its birth with thinkers about land and power, such as England's Halford J. Mackinder and with Germans in the nineteenth-century school of "world politics." In the post-1918 era (when Germans would have done best to advance their genius for science, music, and liberal arts), a newer school of geopolitics led by Dr. Karl Haushofer of Bavaria pointed ahead to Germanic expansion. The "place in the sun" demanded at the dawn of the twentieth century and leading directly into the First World War of 1914-18 was again demanded by voices much louder and cruder than Professor Haushofer's. ${ }^{8}$ Ruinously associated with two world wars and unspeakable genocide, the term geopolitics almost vanished from use except as a kind of slur for most people in the decade after 1945.

But reality did not recede. And with time, a new and calm school of thoughtful academics have again come to the study of geopolitics and the proper use of it within other security studies. Colin S. Gray of the United Kingdom; the late Cold War scholar Harold W. Rood; and the younger American student of both, Professor C. Dale Walton, are among those to mix new ideas with old to produce things worthy of the strategist. ${ }^{9}$

\section{Strategic Culture}

Strategic culture is a newer term and a kinder enterprise. Some find it a gentler way to talk about geopolitics, and others see it as opening up war studies to useful ancillaries such as anthropology, psychology, sociology, and other concepts currently favored in graduate schools, such as studies in women, peace, and security. Those taking the pathway of strategic culture usually carry little with them of the work of the earliest geopoliticians, but they may offer much about power politics and how countries choose war or perform once in a war. At its worst, strategic culture is a maddeningly elusive phrase and part of an argument that certain outlooks on violence or approaches to security are attached to a given group (e.g., American Confederate generals in the Civil War, Han Chinese officialdom, or Pakistan's powerful bureaucrats in the Inter-Services Intelligence). Most advocates for the phrase keep their observations general, lest they sound simplistic or even racist, yet that makes them imprecise. They also drift in one direction: a China expert may write about three or four continuities as being expressions of a strong strategic culture, but this never seems to answer an obvious question. How is that one society, within little more than half a century, had its armies controlled by four men of wildly different outlooks? Consider a Qing emperor indebted to Confucius; democratic reformer Sun Yat Sen; the Marxist-Leninist atheist Mao Tse Tung with his highly original protracted war theory (which Sun Tzu would have condemned); and then the near-anti-Maoist 
Deng Xiaoping, who produced another kind of military revolution. Can any declared strategic culture in China encompass all of these variations?

Perhaps a strategic culture advocate would rejoin that some important continuities can indeed help us understand the China of 2019. Mao praised much that could be found in the ancient book The Art of War by Sun Tzu, and both these Chinese authors matter as much as ever. Additionally, there are current official Chinese publications on defense that show many historical allusions and deceased strategists' names, Western as well as Eastern-doubtless with good reason. Our drive to understand a rival's strategic culture is a worthy one, a natural part of the assessment process intelligence experts, general staff officers, and social scientists are rightly taught to perform.

Innovations, more so than continuities, are also visible in the ancient rivalries. When Rome made war on the empire of Carthage, the latter's power prevailed over most of the Mediterranean Sea. In the Second Punic War, Hannibal invaded Italy proper. But it was the special insight of the Roman general Fabius (Quintus Fabius Maximus Verrucosus in full) to see that: (a) Hannibal could become bewildered if his Roman opponents declined to meet him, month after month, in possible battles on their own home ground, and (b) that the Roman administrative system across Italy was stable and steady enough to take a pummeling by an invader and survive without breaking. Hannibal, undefeated, broke off and returned to Carthage-only to be beaten on his home ground by another Roman general, Scipio Africanus, whose legions arrived via the sea. The Punic Wars thus witnessed major Roman innovations in strategy and saw dramatic enhancement of the range of Roman abilities. This Italian land power came onto the sea not just in moving legions but in fighting great naval battles. The rivals' third war confirmed the ruination of Carthage, its loss of both land and seapower, and the ascendancy of a Roman empire. ${ }^{10}$

\section{Ideologies}

Ideology is often more explicit, more plainspoken, and sometimes more brutal than are our modern ideas of strategic culture. The French Revolution of the late eighteenth century was internationalist in its character and arguably dictated that violence would be exported to conservative autocratic zones of Europe beyond the borders of France. ${ }^{11}$ Napoleon Bonaparte's special and devious ability was to inherit a mass popular movement and to despotically direct political and social powers into transnational advances and conquest. Other internationalist ideologies followed-anarchism and Leninism-which also came with certain tendencies: a global vision, ideological agents abroad, and readiness for fighting abroad.

Nationalism is no less important. There is almost no way to understand the German Third Reich-in expansiveness, in depredations against non- 
Germanic populations, or in its Axis alliance with Italy-unless one comes to grips with the ideology of National Socialism. Adolf Hitler understood his school of thought to be a revolutionary ideology, not just another normal political formation. He knew, as did many professional officers in Austria and Germany, that this new mid-twentieth-century program of thought and action directed by the National Socialist German Workers' Party and glorifying force had constituent parts that defied a thousand years of German culture, even as they also built on martial strengths garnered in the three wars of Bismarck from 1862 to 1870 .

\section{Coalitions}

Battle studies have immense value, especially for the education of military officers. Such investigations and dramas may teach and also dazzle: focus on the great captain Napoleon's battles shaped much of the Western world's military education for an eon. But maturing officers and other students of strategic matters come to take as much interest in coalitions. The Third German Reich was destroyed by 1945 in the same way as the First French Empire in 1815-by massive coalitions. Otto von Bismarck, whose wars helped define the intervening era, understood that power may be intoxicating but that it also yields counteraction by neighbors, near or far. An opposing coalition (a balancer against the would-be hegemon, to use the term of political science), may not really cohere for years, as against Napoleon. Or, it may come together with swiftness, as with the U.S.-UK alliance formed in 1940 and 1941, even before the attack on Pearl Harbor, Hawaii. When great coalitions do form, all earlier balancing of powers may become obsolete. By the time World War II ended, only a handful of states in the world had not taken a side. This successful Allied grand strategy was crucial. By contrast, Hitler appeared brilliant in 1936 or 1939 only to break with consuls of common sense by making war on two fronts - just as he broke with history's lessons against marching upon Moscow. Faring badly, he doubled the gamble and went to war with all the world.

Not many enemies make such blunders. Some in command consider well the lessons of past coalition wars. As a rising state, China explicitly takes notice that the unipolar world of 1990 has been vanishing. China thinks of its pre-nineteenth century greatness as the true norm, vis-à-vis any period of American preeminence in the Pacific. The disquieting skills of China in the twenty-first century go beyond technical successes in copying advanced Russian and American weapons or building more supercomputers than any other state. Americans disturbed with how China acquires U.S. laboratory research results should pay as much attention to how China is buying or borrowing our allies. Fortunately, Vietnam is still wary and remembers the PRC invading in 1979. Australians were not swayed by a visit of three PRC warships in Sydney Harbor 
in June 2019. But the Republic of the Philippines has been dislodged from its former coalitions, disoriented in ways to be noticed by students of Sun Tzu. Manila is adrift, and the shift is toward Beijing at the expense of seven decades of formal alliance with the United States. This has happened at the same historical moment when a Permanent Court of Arbitration agreed with Manila's lawyers that China is wrongfully encroaching on Filipino maritime rights. ${ }^{12}$ It is also happening when whole sectors of Filipino opinion makers worry about foreign narcotics, most of it from China or the product of precursors from China. Washington and Manila must account for the shadow over their alliance, and legislators should be suggesting what the two capitols could be doing.

Other regional actors, such as Thailand and Malaysia, could suffer the same fate of seeking out new coalitions. Will they become like Burma, which is cleaved in tribal and political parts by low-intensity conflicts, perpetrated in some respects by China, and seemingly without good leadership? ${ }^{13}$ Such tendencies could be surmounted if America improved its alliances, but few believe the United States is doing so. Gratitude is due to Japan, a superb ally and a powerful security partner. Yet, consider how one U.S. president bulldozed Japan into joining the Trans-Pacific Partnership and then the next made the United States defect from that same trade agreement. ${ }^{14}$ This is indicative of the uncertainty that may lead some allies to reconsider how reliable the United States is. Meanwhile, two U.S. security allies, Japan and South Korea, quarrel and have decided to not renew an important partnership in the exchange of military information. ${ }^{15}$

\section{Regional Alliances and Arrangements}

The study of geopolitics helps account for such changes in alliances and also the rise of new regional arrangements and regional alliances. As America wore uncomfortably — and could not keep — the cloak of unipolar hegemony, big powers such as Russia and China may create new problems for themselves as they push outward assertively, breaking political and geographical barriers. In this vision, President Vladimir Putin's investments in Venezuela at the moment may garner him some prestige, but Russia does not need anything Venezuela produces, including oil, that it could not already enjoy—if at slightly higher prices. China's bullying of small democracies may attain short-term gains but lose out in the long run. If these small nation-states are supported well by the United States and others, they may rally against Beijing or other international great power rivals, as Vietnam already has against Beijing.

Other causes will yield new alliances, and Washington must move with the opportunities instead of watching opportunities lost. There is no reason to accept a "tripolar world" of great powers if the accepted troika is Russia, China, and the United States; this excludes approximately 200 more countries, which 
may not wish to see Moscow and Beijing pushing for more global influence. The "balancing" that fascinates observers may be as assured as any other continuity of international relations. One should welcome the slowly strengthening role of the African Union in peacekeeping missions attending to African hot spots. A much stronger and more partisan Association of Southeast Asian Nations (ASEAN) is sadly unlikely yet would be welcomed by democracies everywhere, and one might say the same of the Organization of American States (OAS). Fortunately, the North Atlantic Treaty Organization (NATO) is the globe's leading example of longevity for an active alliance, a significant achievement that inspires envy in many national capitals. Russia and China may have taken account of the expansion of NATO when they formed their new Shanghai Cooperation Organization in 2001 (then consisting of six states). A tendency toward new or refreshed regional alliances may also be encouraged by the new authoritarians so often in the world press. Abdel Fattah el-Sisi of Egypt, Viktor Orban of Hungary, and Recep T. Erdogan of Turkey offer examples of leaders who have their own views and can choose a third way. Just as Vladimir Putin and $\mathrm{Xi}$ Jinping are now friendly to each other at summits, leaders of medium-size powers may find or forge new regional or transnational relations to offset larger trends that disturb them, such as great power acquisitiveness or commercial domination.

\section{New Forms of Power}

The above fundamentals remain, even as students of great power rivalry identify industrial and technical revolutions that at times open new windows into military opportunities or cause strategic shifts. At the same time, the complexity of judgments about what kinds of power are important have been increasing. Our earliest chronicles of war emphasize land power, including the genius of commanders such as Julius Caesar of Rome and Alexander the Great of Macedonia; these accounts will never lose power to teach. Such men did not just win battles - they used those battles to implement sweeping political changes on the face of the Earth to create empires where there had been smaller states and cities. Mahan and his gifted English counterpart Julian Corbett became the late nineteenth century seapower theorists and, in effect, advisors to senators, ministers, and kings. The Influence of Sea Power upon History was translated into German and placed on every German warship before $1914 .{ }^{16}$ Industry and logistics have their own domains in war and security. Failings in those paired aspects of power have cost nations wars. In this realm, it is clear that states must perform thoughtfully and thoroughly during peacetime; if they wait until war starts, it is too late. Logistics and martial industry are central to why grand strategy is as important as campaign or battle strategies.

Airpower has emerged proudly in the past hundred years. Italian theorist 
Giulio Douhet is thought to have overstated the case for bombing in the preWorld War II era but others with more balanced hopes for aerial weaponry have seen remarkable successes. The People's Liberation Army (PLA) colonels who wrote Unrestricted Warfare in 1999 showed the closest interest in the Coalition's swift 1991 victory over Iraq; the authors were simply agape at the results. ${ }^{17} \mathrm{Few}$ readers noticed how they heaped praise on the military helicopter as a new king of battle-one of many indicators of the changes flitting across the old face of war.

The militarization of space was emerging as a question late in the United States-USSR rivalry, with published discussion of satellite killers, space-based lasers, as well as the launching of spy and reconnaissance satellites by both countries. Russia and China today are adapting to this new realm, prompting the White House to create a Space Force. There is the new and emerging threat of using cyber powers against adversaries. Massive well-planned attacks have offset computer systems, industry, and civic infrastructure in Georgia, Iran, Ukraine, and other countries. It is obvious that this new realm must be addressed when a state as small as the rogue North Korea can stun an American corporation and is purportedly behind the massive WannaCry attack, and when another as small as Estonia has determinedly made itself a master of cyber defense, much to the advantage of NATO.

Any astute observer cannot ignore soft power. To the well-known forms of "prestige" or "good will" are now added all manner of subtleties, from influencing foreign populations' elections as Russia has been doing, to shaping a (relatively new) public diplomacy apparatus within the U.S. Department of State as the Americans have tried. There are good reasons for the smiles of China's president Xi Jinping on various global stages in these past few years. The calm grins reflect his country's increasing influence, and they also reflect satisfaction taken in the ambitious plans, expensive investments, immense labors, and patient outreach that lie behind those Chinese gains below the level of open conflict. China has successfully combined soft power and economics in enterprises abroad.

Thus, the duo of PLA colonels (Liang and Xiangsui) have argued that warfare is now "unrestricted" in three main ways. First, the diameter of the mouth of one's cannons is less likely than ever to be decisive. We see a relatively new cluster of means of competing, fighting, or both. These include trade wars, currency manipulation, international terrorism, and information warfare. The two authors assert that, really, there is nothing that cannot be a weapon of war. Second, what will be most novel are unusual combinations of these tools by the civilians and military officers making war. Before, one had to study the remarkable skill and timing of Robert E. Lee's combined cavalry with infantry on a given field; now, a government is likely to strike with an electromagnetic pulse 
(EMP) and a disabling blow to several satellites in concert with an amphibious landing, etc., all within the first hours of conflict. We have not even mentioned nuclear weapons, which, intriguingly, the book Unrestricted Warfare touches on only in the category of less likely to be used. ${ }^{18}$ China is among the many powers that has nuclear weapons. Rivals to China, Russia, and other regimes will find a continued need of their own deterrent forces.

\section{Future Wars}

To peer into the future as one would "through a glass and darkly" is a task as worthy as it is difficult. One set of results, in such an inquiry, might come as "alternative futures." The first of those may well be akin to Unrestricted Warfare, which deserves a closer analysis. Coauthor Qiao Liang graduated into the flag ranks and still serves; coauthor Wang Xiangsui is now with a Chinese think tank. Their book seems too original and compelling to be dismissed as some kind of deception aimed at geopolitical rivals. It is a worthy prompt to our own thinking within the space granted by peacetime to work on questions of grand strategy, military strategy, and procurement. This vision, if we may adumbrate it here, pays no heed to known rules of warfare or international law. It speaks of "increased global disorder"-also the concern of the 2018 U.S. National Defense Strategy — not as something to be worried over and resisted but as a natural condition, almost to be embraced. It anticipates semi-chaos and the timely maneuvers of clever states within such disorder. And should real war come, the two authors seem to anticipate speedy, devastating conclusions without saying so directly. The whole concept is a direct challenge to our age-old "just war" views and Westphalian ideas of a hard difference between war and peace and our surety that when war comes it is only a loathsome interval to be managed victoriously so as to return to peace and order.

Perennial low-intensity conflict, a sort of expected violence short of outright organized war, is a related but differing alternative future for the world. In this vision, elements such as organized crime, insurgency, and terrorism erode the power and legal sovereignty of established states. All states, large and small, are affected. It is the Philippines, nowhere near to collapse but plagued by Islamic State fighters, Moro gunmen, old resentments, and the Maoist New People's Army, which just reached 50 years of age. It is a once-promising Myanmar that, despite efforts by a few noble democrats, cannot drag itself out of ethnic violence and into the twenty-first century. Visits there by President Obama and Secretary of State Clinton are forgotten, while military authorities mix their old authoritarianism with new Buddhist revivalism to encourage violence against the Burmese Muslim minority. India, a stunning success story, is dogged by fighting in the North Eastern Region and Maoists in the central eastern "red belt." In this universe, great powers may not wish to risk all in a major conven- 
tional war. Instead they compete, harbor their powers, and carry on proxy wars in borderlands or the cockpit of the Middle East or Afghanistan, while adhering to unwritten rules about nonescalation with major rivals. Private armies and mercenaries may attain unusual power in such a world. ${ }^{19}$ There is a grinding, gritty realism about this vision, but it overlooks two dangers. One is that a substate group can arm itself with a weapon of mass destruction. If a terrorist attack on New York's Manhattan led to major international conflict in the fall of 2001, could not something as world altering occur in 2021 if any great capitol were voided for years to come by a biological weapon? The second danger is that widespread anarchism and chaos lead directly to dictatorships who allege they can clean it up.

A third alternative view is that major state war is highly possible and even probable. Winston Churchill's magisterial six-volume history of World War I has an early passage evoking images of British statesmen floating, as if on a gentle sea cruise, through a calm, palmy world, unable to imagine a globe that is not dominated by the queen's reach. Here was a fine time of unparalleled wealth, a large middle class in the West, telegraph-enhanced communications, and growing trade, travel, and literacy linking different peoples in ways almost unforeseen. War seemed impossible to politicians who missed multiple opportunities to prevent world war. Churchill concluded his long, rosy description of how globalization in his day seemed to banish all nightmares, but then he added a sentence of eight short words: "It would be a pity to be wrong." ${ }^{20}$ August 1914 staggered states and burned the reigning popular consciousness. Some say the world never did recover; others say it did, only to have a second world war dwarf the first.

This worldview in which major war must be considered likely utterly rejects The New Rules of War by Sean McFate as decisively as it rejected the 1990 model by Martin van Creveld with the (errant) title The Transformation of War. ${ }^{21}$ Real war has not vanished. Real wars with tanks, aircraft, battleships, and armored amphibious vehicles were fought and won by powerful belligerents such as the United States in Iraq in 1991 and 2003. And the United States has needed masses of equipment and very large professional forces to make important local wars in Vietnam, Panama, Grenada, and Bosnia. China and Pakistan have both battled India since 1947, and now all three countries have nuclear weapons and at times mutually loathe one another. Crime bosses, intifadas, and al-Qaeda terrorists remain with us yet have not replaced state governments in this world. If Yugoslavia can disintegrate into a theater war of civilizations, one may also see future situations where a coalition of well-organized outside "Clausewitzean" state powers storm into a fracturing nation-state to restore order. If Middle Eastern states such as Syria and Iraq can seem to disintegrate under the Islamic State's revolution, then again the system of states has struck back and 
reasserted sovereignty. Following the collapse of the Soviet Union, Moscow has not merely reorganized and tightened its Russian Federation; it is thrusting itself back into the affairs of adjoining nation-states in a fashion many in the Kremlin formerly practiced adeptly. ${ }^{22}$ Today's "gray zone activity" is no more a geopolitical novelty than it was in the 1980s, another era when many members of Congress, executives, and parliaments were grappling with such things. For example, anti-Communist insurgencies and proxy wars of the 1980s were often responses to the earlier Communist wars and subversions sponsored by Moscow and Beijing, which plagued the decades after 1945.

\section{Conclusion}

Decisive and wise leaders may work through, for, or against these trends in international affairs. No one is the master of the United States, and while our choices are sometimes bewildering, they are ours to make. Fate ordains neither global war nor slippage of U.S. power. But good politicians have much to do. Good military leaders, skilled in both the science and art of war, have their own say in the high councils and their own leadership to perform. It is the recommendation of the author that history, prudence, and patterns in past strategies all suggest something important (and occasionally brutal to those who neglect it): despite the swirl of changes always buffeting the world, there are fundamentals and continuities that never vanish and always demand renewed attention. This is the nature of warfare that Clausewitz described so well as against something he also understood and experienced: the varied "character" of a given war that is so visible, present, and demanding.

\section{Notes}

1. James R. Holmes and Toshi Yoshihara, "The Influence of Mahan upon China's Maritime Strategy," Comparative Strategy 24, no. 1 (2005): 23-51, https://doi.org/10.1080 101495930590929663. Consider pp. 24-25: "Mahan's influence on Chinese strategic thought was palpable, for instance, at a symposium on 'sea-lane security' held in Beijing in the spring of 2004. Scholar after scholar quoted Mahan at the symposium, attesting to his influence. And, almost without exception, they quoted the most bellicose-sounding of Mahan's precepts." The author's own studies in translated Chinese sources can confirm such interest, as in an official 2013 reference to that "outstanding" treatise by A. T. Mahan, The Influence of Sea Power upon History, 1660-1783 (Boston, MA: Little, Brown, 1890). As someone who began in the late 1980s to collect all of A. T. Mahan's books, the author recommends (to today's reader interested in China) not just his 1890 study and its introductory essays and six "elements of sea power" but also A. T. Mahan, The Problem of Asia and Its Effect upon International Policies (Boston, MA: Little Brown, 1900).

2. Toshi Yoshihara and James R. Holmes, Red Star over the Pacific: China's Rise and the Challenge to U.S. Maritime Strategy (Annapolis: Naval Institute Press, 2010), and the revised $2 \mathrm{~d}$ edition, 2018. On Mahan, see especially pp. 16-18 of the first edition of Red Star.

3. These sentences refer to long-term leases, Chinese foreign aid in maritime matters, etc.; they do not refer to intellectual property theft or that fiction the "9-Dash Line." 
The latter is a Chinese maritime claim reaching eastward to all but capture the South China Sea, leaving mere littorals for the Philippines, Brunei, Malaysia, and Vietnam. Formalized by the PRC in a 1951 assertion, it is not deemed credible by outsiders and was recently rejected by a world court of arbitration.

4. A few such patterns were explored in the author's chapter "On Strategic Thinking: Patterns in Modern History," in Statecraft and Power: Essays in Honor of Harold W. Rood, ed. Christopher C. Harmon and David Tucker (Lanham, MD: University Press of America, 1994), 55-86. Others who have written better on this theme of strategic "patterns" include Williamson Murray and Eliot A. Cohen. See, for example, the latter's fine essay on "The Historical Mind and Military Strategy," Orbis 49, no. 4 (Fall 2005), https://doi.org/10.1016/j.orbis.2005.07.002.

5. White House, "FACT SHEET: Advancing the Rebalance to Asia and the Pacific," press release, 16 November 2015.

6. There is a related comment in memoirs of Sir Sydney R. Fremantle. The deputy chief of naval staff of Great Britain noted that "the strategical advantages possessed by the enemy in the existence of the Kiel Canal, which enabled him to move his Battle Fleet at will ... to the North Sea or the Baltic." Quoted by Paul M. Kennedy, The Rise and Fall of British Naval Mastery (London: Ashfield Press, 1987), 257.

7. Larry Cosgriff (Merchant Marine expert), interview with author, Washington, DC, 3 June 2019. According to Cosgriff, "The largest projects China has undertaken in Panama for their own account are marine terminal concessions on both ends of the canal. Hutchison Whampoa built and operates container terminals at both ends of the canal under long-term concessions with the Government of Panama ... China is building a bridge across the canal FOR the Government of Panama, but will not have any ownership of same. . . Huawei actually operates one of its largest distribution centers from inside the Colón Free Trade Zone. Finally, China was also contracted to build a large passenger cruise terminal on Perico Island off Panama [but the status is unclear]."

8. In a 1901 speech, the ambitious young Kaiser Wilhelm II spoke of how Germany had conquered for itself "a place in the sun" and went on to make clear that he aspired for that nation's place to be enlarged. The phrase thus appears in many histories, for example, Fritz Fischer, Germany's Aims in the First World War, trans. (New York: W. W. Norton, 1967). In the late 1920s and early 1930s, Professor Karl Haushofer was known as a well-educated officer of dignity, according to Charles Robert Harmon, an American historian who later studied papers and diaries at the family home near Munich. This was forgotten — and became almost irrelevant—given the unmistakable linkage of some of Haushofer's geopolitical ideas to fascist aggression and the taking of "living space." See Derwent Whittlesey, "Haushofer: The Geopoliticians," in Makers of Modern Strategy: Military Thought from Machiavelli to Hitler, ed. Edward Meade Earle, with Craig Gordon A. and Gilbert Felix (Princeton, NJ: Princeton University Press, 1943), chap. 16.

9. Dr. Gray and Dr. Rood have each lectured at Marine Corps University. Dr. Walton is the author of several books, including Geopolitics and the Great Powers in the Twentyfirst Century: Multipolarity and the Revolution in Strategic Perspective (New York: Routledge, 2007).

10. Mahan devoted a short preface to the Roman-Carthaginian contest; see The Influence of Sea Power upon History.

11. Among those who would indeed argue the point are Steven T. Ross, who deprecates the idea that this revolution was "exported" by the French. Steven T. Ross, European Diplomatic History, 1789-1815: France Against Europe (Malabar, FL: Robert E. Krieger, 1969). The author was able to confirm the professor's view, some 20 years after his book appeared, when both served on the strategy faculty of the Naval War College.

12. Thomas A. Mensah et al., In the Matter of the South China Sea Arbitration before an Arbitral Tribunal Constitute under Annex VII to the1982 United Nations Convention on the Law of the Sea between the Republic of the Philippines and the People's Republic of China, PCA Case No. 2013-19 (The Hague, Netherlands: Permanent Court of Arbitration, 2016). 
13. Bertil Lintner, "Myanmar's Wa Hold the Key to War and Peace," Asia Times (Hong Kong), 6 September 2019.

14. Don Lee, "Trump's Withdrawal from TPP Trade Deal Is Hurting U.S. Exports to Japan," Los Angeles (CA) Times, 25 April 2019.

15. Cheng Xiaohe, "Demise of GSOMIA Deals a Blow to U.S. Indo-Pacific Strategy," Global Times (Beijing), 1 September 2019.

16. Holger H. Herwig, "Luxury" Fleet: The Imperial German Navy, 1888-1918 (London: Ashfield Press, 1987), 20, 40.

17. Qiao Liang and Wang Xiangsui, Unrestricted Warfare, trans. and published as the Pan American Edition, with introduction by Al Santoli (Dehradun, India: Natraj Publishers, 2007).

18. Liang and Xiangsui, Unrestricted Warfare, 44, 123.

19. See, for example, the chapters "There Is No Such Thing as War or Peace-Both Coexist, Always" and "Mercenaries Will Return," in Sean McFate, The New Rules of War: Victory in the Age of Durable Disorder (New York: William Morrow, 2019).

20. Apart from those eight words, these sentences are the author's paraphrase of passages in Winston S. Churchill, The World Crisis, vol. 1, 1911-1914, 3d ed. (London: Thornton Butterworth, 1924), 49. Now neglected, even by historians, this six-volume work written after the First World War is, among other things, an important treatment of geopolitics and great power rivalries.

21. McFate, The New Rules of War; and Martin van Creveld, The Transformation of War: The Most Radical Reinterpretation of Armed Conflict Since Clausewitz (New York: Free Press, 1991). In the late twentieth century, there was much valuable conversation in security studies about whether war's very nature had been "transformed," especially due to increased power of substate groups, and the influence of terrorism. The present author rejects that view. With Christopher Bassford and many others, the author tends to the view of Carl von Clausewitz that while the character of wars (or even a given war) may well vary, there is below a fundamental nature of war that is unchanging and must therefore be deeply appreciated. Perhaps our focus, now in the early twenty-first century, on "great powers" underscores this wisdom of Clausewitz.

22. It is valuable to look back at the article by Kevin D. Smith, "The Soviet Re-Union," Strategic Review (Fall 1995): 71-75. The article drew little attention, and even the journal has lapsed, yet both were excellent. 


\title{
The Amphibious Imperative of the French and Indian War
}

\author{
T. J. Linzy, PhD
}

\begin{abstract}
In the French and Indian War, Britain's arrogance in land warfare in North America resulted in two years of near constant defeat and devastation to its forces and colonial residents. However, through an open-minded analysis of the situation, Britain improved its planning, logistics, diplomacy, tactics, operations, and strategy to make the most of its naval superiority. In a war where agile, irregular, and amphibious warfare were required to win, Britain adapted and won. Their processes and actions provide a classic study for modern-day joint operations leaders to examine.
\end{abstract}

Keywords: amphibious operations, Roger's Rangers, light infantry, British Royal Navy, French and Indian War, Seven Years' War

\section{The Pertinence of History to Strategy}

s strategy studies professor Colin S. Gray has pointed out, there is a
delicate relationship between historians and strategists. Although most
will not dismiss history outright, many modern strategists think that
history is too specific, and twenty-first century warfare too complex and dy-
namic, to derive much from it. ${ }^{1}$ However, both Gray and the equally eminent
naval historian professor emeritus Geoffrey Till have made the point forcefully
that history case studies are thinking aids for the preparation of strategy, not
prescriptive blueprints. In other words, the study of history is a mental exercise

T. J. Linzy is a former cavalry scout with the U.S. 2d Cavalry, business owner, and U.S. Air Force historian. Linzy holds a master's in the history of warfare and a doctorate in war studies. His opinions are his own and do not represent the U.S. Air Force or the U.S. Army's $2 \mathrm{~d}$ Cavalry Regiment. 
for the well-rounded strategist, not a how-to or how-not-to manual. Geoffrey Till's often-quoted advice is worth mentioning again:

The chief utility of history for the analysis of present and future lies in its ability, not to point out lessons, but to isolate things that need thinking about. ... History provides insights and questions, not answers. $^{2}$

The long history of the British Empire provides a wide range of situations across the globe to study, especially in naval and amphibious operations. As each course of action is studied and categorized, an exception can be found. As each exception is studied, deeper appreciation of the decisions is obtained. Again, the goal is not to find a shortcut but to understand the decisions, courses of action, and outcomes better. This practice provides insights and better sources of inquiry. This article focuses on the French and Indian War at the beginning of the British Empire as a case study to examine the plentiful amphibious operations at the tactical, operational, and strategic level, comparing and contrasting the choices made by Britain and France in North America. ${ }^{3}$ Specifically, it focuses on how Britain advanced from a naval power that could transport troops trained for warfare on the European continent around the world to a true joint operation superpower that could conduct a range of land operations amphibiously at will.

\section{Background to Conflict}

By the mid-1750s in Europe, diplomatic and royal machinations had led to a reversal of old allies. Prussia and Britain aligned against Austria and France contra their alignment in the previous War of Austrian Succession, which occurred from 1740-48. ${ }^{4}$ Only France and Britain remained traditional enemies. Further, Russia, Spain, and Saxony aligned with France, while Britain's Hanoverian king George II protected Hanover and smaller German protectorates with Prussia. These alliances would dictate what would happen on the continent, but the overseas war would be primarily between the two strongest actors-Britain and France. ${ }^{5}$

From the late seventeenth century to the midpoint of the eighteenth, Britain and France had fought wars in North America that were generally extensions of European conflicts. Most of these wars began in Europe with the North American conflicts being ancillary to the main European theater. The fighting in North America was also primarily between colonial forces and their native allies. However, the war that became the global Seven Years' War-known as the French and Indian War in North America-was precipitated largely by North American issues and conflict. Previously, North American land claims had, for the most part, remained distinctly separate, with the Spanish in the south and 
southwest, the English on the eastern coast, and the French in the northern lakes and interior river valleys. However, around 1750, the English began to aggressively explore and claim areas in western Pennsylvania and Virginia near the Forks of the Ohio River. The forks were a confluence of two major rivers- the Monongahela and Allegheny Rivers - that formed the Ohio River.

The French had operated in the area using the soft power of trade with as little impingement on the indigenous way of life as possible. Few French settlers entered the area, preferring to stay near the Saint Lawrence River settlements. The interior was traversed by French frontier traders, coureur de bois, which sometimes intermarried with the Native Americans and adopted their lifestyle. As Richard White stated, the French government, traders, and trappers often sought a middle ground with the Native Americans by employing a light footprint model of colonialism. The various tribes of the Ohio region managed a largely peaceful coexistence with the French, because they were not entering the Ohio region in large numbers and did not try to acquire massive plots of land for agriculture or speculation. ${ }^{6}$ This was not what the English had in mind. The French had a population of only 60,000 people in North America, while the British had 2 million. The British colonies were continuing to receive settlers from Europe who wanted land. The aggressive use of the soil on the East Coast also meant that some of the oldest plantations were exhausted from overuse. The British model entailed trading with the Native Americans as well, but the English traders were followed by settlers who came en masse and wanted land for cattle and farming. Some of the land on the East Coast had been obtained legally from the Native Americans, but other situations involved fraud, theft, and manipulation. As the English enticed eastern Ohio Country tribes with trade, tribes that had been aligned with the French leaned more toward the British. Fearing loss of influence, the French began to exercise more control over the area. Then tensions began to rise. ${ }^{7}$

In late 1753, Major George Washington of the Virginia militia was sent by the Virginia lieutenant governor Robert Dinwiddie to meet the French commander of the Ohio Country to claim the area for Virginia. The mission failed, as Washington was told politely but firmly that the French had no intention of leaving the area. Dinwiddie was not deterred. In 1754, Dinwiddie again sent Washington to the Forks of the Ohio with a military force to secure the area. The French had constructed forts and portages at key points along the major rivers and lakes in the Ohio Country. This gave them a movement and logistical advantage over the British, who had to traverse dense forests and the Appalachian Mountains to reach the forks. Before Washington could reach the forks, he came into contact with a French party who claimed they were on a diplomatic mission, but Washington attacked before the French message could be received. In the following altercation, a wounded French lieutenant was killed 
by one of Washington's indigenous allies. Washington found out the hard way that his objectives and the objectives of his Native American allies were not exactly the same. Fearing his force would be overcome by a follow-on French force, Washington retreated to an impromptu fort and awaited the French response. A larger French force did come and enveloped the poorly constructed fort. Washington surrendered under what he thought were generous but normal terms written in French, only to find out later that he had admitted to assassinating the French diplomatic envoy. Thus, brewing tensions in Europe were further enflamed by actions in North America. Along with the reversed alliances in Europe, this war would reverse the history of where European wars would start. ${ }^{8}$

At this stage, the British forces were woefully underprepared for military confrontations in North America. Although less populated than the British colonies, New France did have considerable regular forces in their Troupes de la Marines (French Marine regulars in New France) who had significant experience in the wilderness of the Ohio Country and far more indigenous allies. The Troupes de la Marines were formidable fighters in European-style warfare as well as irregular warfare as practiced by the Ohio Country tribes. Washington's ill-trained militia and volunteers were no match in training or experience. Britain would need to improve its capabilities in North America if it was going to compete with the French.

\section{The War Begins}

When word of Washington's failure made its way to London, the British leadership felt they could not let the French insistence on retaining the Ohio Country stand. The British decided to send the experienced British Army major general Edward Braddock to take command of the military effort in North America. Braddock arrived in early 1755 with two understrength British Army regiments from Ireland. Upon arriving, Braddock managed to upset everyone he came into contact with due to his arrogance. Having had no experience in North America, Braddock developed an ambitious but complicated plan to subdue French influence in North America.

Braddock's strategic plan was to cut off French resupply by taking key points along the Saint Lawrence River while simultaneously taking the Forks of the Ohio forcefully with a main column that he would lead personally. His would be an overland route through wilderness with a huge logistical train. The other three would be amphibious campaigns in one form or another. One would have a small unit leader at its head and move to meet one of Europe's best French generals along the Lac du Saint Sacrament (later named Lake George) and the Lake Champlain corridor to secure the prominent French Fort St. Frederic (Crown Point). Another, led by the governor of Massachusetts, would 
attack along Lake Ontario to secure Fort Niagara and control the Great Lakes supply chain. The final campaign would conduct a seaborne landing to secure French forts in Nova Scotia. The three amphibious operations were designed to cut off the Ohio backcountry from further French support. ${ }^{9}$

Had this strategic plan included the advantages of professional leadership in each campaign, reliable allies, knowledge of the wilderness, and solid infrastructure, it might have succeeded. However, none of the above had been prepared, trained, or executed at this scale by the British before. The British had great strengths in naval superiority over the French, but had decided to focus primarily on areas where the French had the greatest strengths. Poor leadership and an arrogant ignorance of the difficulties of supplying large forces in the North American interior hobbled the British effort from the beginning. Colonel Robert Monckton's expedition up the Bay of Fundy to take the French forts in Nova Scotia was the one campaign where British naval strength was brought to bear and that mission was a success. General Braddock's march on the Forks of the Ohio failed due to his inability to draw in native allies, a huge pack train, and, finally, undue haste. The remaining two amphibious operations along rivers and lakes were beset with political squabbling, logistical problems, and the loss of the allied Iroquois after disastrous Iroquois losses on both sides at the Battle of Lake George on 8 September $1755 .{ }^{10}$

Although each of the four campaigns would be conducted successfully later in the war, the British simply were not ready to execute the kind of missions required to support their correct strategic analysis in 1755. The French, on the other hand, very successfully played to their strengths early in the war, but feared that British naval superiority would hobble them by cutting them off from sea communications with France.

Following the debacle of the 1755 British campaigning season, the British colonists' frontier settlements were extremely vulnerable. The only thing stopping French forces from pushing east and suing for peace was the fact that a huge chunk of their force had expended itself at the Battle of Lake George, including the capture of senior French general Jean Armand, Baron von Dieskau. The New France governor general Pierre de Rigaud Vaudreuil de Cavagnial and his Troupes de la Marines officer brother, Francois-Pierre de Rigaud de Vaudreuil (often referred to simply as "Rigaud" to distinguish the two brothers), were both North American born and bred. They supported the indigenous way of war and released their native allies, with and without French accompaniment, to terrorize the British colonies' frontier. From the winter of 1756 to 1757 , the British frontier was pushed back to within 200 miles of the Atlantic Ocean. The French wanted to create a buffer to protect their vulnerable line of supply from Canada to Louisiana. They thought that if they thoroughly demoralized those on the frontier, they could focus on keeping their native allies happy long 
enough for French forces in Europe and at sea to mitigate the British numerical advantage in North America and at sea. ${ }^{11}$

In 1756, the French and the British sent new leaders to North America. France sent an experienced general named Louis-Joseph de Montcalm-Grozon. Montcalm was well respected in Europe and would be a serious challenge to British plans. However, Montcalm was not in agreement with Governor General Vaudreuil on how to prosecute the war, especially on the topic of unleashing native allies on the frontier. Vaudreuil held the political and military power in 1756 and into 1757, but Montcalm would not take the situation sitting down. The British sent General John Campbell, the Fourth Earl of Loudoun. From the beginning, much like Braddock, Loudoun managed to estrange virtually all of the royal governors and legislatures of the colonies by being imperious about what the colonies owed him as the British military commander and how they would be treated in the British military establishment. Loudoun's tenure produced no significant victories. The strategy on both sides would remain largely the same, but with infighting causing different results. ${ }^{12}$

The war in Europe began during this period and the military and diplomatic maneuvers there preoccupied both Britain and France. However, Montcalm did manage to take Fort Oswego on Lake Ontario in 1756, allowing France to retain its interior communication lines and putting pressure on the colony of New York from the west. He had prepared for taking Oswego by sending a raiding party of Troupes de la Marine and natives to sever the supply line at a key portage along the Mohawk River Valley. He also solidified his hold on the northern New York frontier by capturing Fort William Henry at the base of Lake George. Both of these fort actions were classic siege maneuvers marred by atrocities, as defined by European customs at least. After the British surrenders at Forts Oswego and William Henry, Montcalm's native allies pillaged and murdered many of the survivors. These actions would cause Montcalm to double his resolve to confront Vaudreuil on the wisdom of using the natives in warfare between two European powers. Montcalm thought that the defense of New France would be best accomplished by holding the line of French possessions using traditional European tactics of defense. As a traditional European officer, Montcalm abhorred the atrocities that he had little power to contain as long as Vaudreuil supported the use of natives in French operations. Vaudreuil, steeped in the native cultures and practices, saw the need for their indigenous allies as a necessary evil, because France could not fight Britain in the standard way due to their rival's superior navy and manpower advantages. Vaudreuil believed that if France lost the offensive initiative, it would be only a matter of time before Britain shut down its warmaking capability via the Saint Lawrence River. Objectives and means had rarely been so at odds in Europe for the French, but the conundrum was an old one in North America. ${ }^{13}$ 
For all their problems, mainly caused by Loudoun and the reticent colonial governments, the British Army was not totally complacent during this time. The younger officers in the British regiments, by necessity, experimented with frontier tactics, equipment, and formations. The British leadership also listened to the well-respected indian agent, William Johnson, on how to engage with the natives to secure their support, if not accepting all of their cultural norms in battle. British Ranger units, led by men such as Robert Rogers, operated in the French and native ways to attack isolated French units and French allied native villages in the northeast. Adopting the ranging way of war led to many improvements but also came with the downside of the irregular warfare tactics, such as killing prisoners because they slowed movements. Combat in the wilderness was proving costly to the European sense of honorable warfare. ${ }^{14}$

However, for all the logistical and tactical improvements in North America by the end of 1757, the war came at a low point for Britain. William Pitt was appointed as the secretary for the Southern Department and the de facto war leader in mid-1757 in a desperate effort to change Britain's fortunes in the war. By the end of 1757, the military situation for Britain, not to mention the London political situation for Pitt, was dire. Pitt and his council of war were highly motivated to leave nothing to chance. As for the Royal Navy and the British Army leadership, the stakes were very high indeed. In March 1757, Royal Navy admiral John Byng had been executed by a Marine firing squad on the quarterdeck of the HMS Monarch (1747) after being convicted in a court-martial for not being aggressive enough against the French in the Mediterranean in 1756 at the Battle of Minorca. The French philosopher, Voltaire, was waggishly quoted as saying, "In this country [Britain], it is thought good to kill an admiral from time to time to give courage to the others." 15 There was little laughing and few disagreements from the political class in Britain and the British officer class took notice. After the debacle at the raid on Rochefort, France, in September 1757, British Army major general John Mordaunt was tried in a December court-martial for his inaction in landing and pressing an amphibious attack. Colonel James Wolfe had been present at Rochefort and was critical of Mordaunt's hesitancy. The Royal Navy commander, Admiral Edward Hawke, was also critical of Mordaunt's lack of action. Mordaunt would later be acquitted, but the confusion about who was responsible for the various stages of the amphibious operations, as well as leaving decisions to councils of war to the last second, were seen as having contributed to the failure at Rochefort. ${ }^{16}$

Britain's naval prowess meant that the British Army was accustomed to being transported by the Royal Navy. However, it took the failed amphibious operation at Rochefort for the two services to reexamine the coordination, communication, and operational procedures required between naval, marine, and army units in seaborne amphibious assaults to change the situation in North 
America. Colonel James Wolfe, a Pitt favorite, had learned much from Rochefort that would be applied later at Louisbourg and Quebec. During the winter of 1757-58, Pitt, First Lord of the Admiralty George Anson; and commander in chief of the forces, Field Marshal John Ligonier, focused on British Army and Royal Navy strategic coordination. The three examined British history, lessons learned, and expert testimony on amphibious operations. Britain may have had some bickering between the navy and the army at sea and in the field, but the London leadership was adamant that the strategic superiority of the Royal Navy had to be married with the British Army to make the most of the nation's strengths. ${ }^{17}$

What emerged was a British military that was still strategically strong at sea, but also was developing new capabilities on land and refining their amphibious capabilities. The interplay of the strategic concepts with operational procedures pored over in London by the British leadership were strikingly modern. In the current lexicon, they would be considered the very definition of "joint" operations. The higher levels of leadership were taking the situation seriously and adapting operational planning to meet specific strategic goals. What remained to see was whether that would translate to the tactical level where so much could go wrong even when the strategy and planning had been strong. ${ }^{18}$

In addition to their seaborne amphibious capabilities, Britain added their improved amphibious knowledge to their newfound light infantry tactics to create effective amphibious operations along the key rivers and lakes that would form their future offensive corridors. This combined effort included detailed planning, increased reconnaissance, nimble logistical trains, and local diplomacy with natives and colonists. The combination of the North American way of war with the Atlantic way of war bore innovative fruit for Britain that would serve them well for the next 50 years. Lighter equipment, looser but still controlled formations, and more nimble organizations allowed for faster action to seize opportunities as they presented themselves. ${ }^{19}$ The ability to mass firepower and act decisively with unity of effort, then as it is now, is the essence of joint amphibious warfare. Combined with the threat of cutting off French support from Europe, the British were assembling the capabilities that, combined with political and leadership changes in 1757 , would set them on a path to conquer New France.

In addition to planning strategic objectives, Pitt, Anson, and Ligonier were deeply involved in assigning the leadership to the specific campaigns. Anson and Ligonier were not averse to skipping over older, more experienced officers in their respective services for younger, more enterprising officers. They assigned Major General James Abercromby as military head in North America, who might have been the exception to the previous statement, but he had strong support from the king. 
In any case, the plan was not much different from Loudoun's, but the key was in the preparation in London and the execution by more junior officers. Ligonier chose Brigadier General John Forbes and Major General Jeffrey Amherst for specific and separate campaigns to achieve while Abercromby would focus on the main thrust with the well-respected acting Brigadier General George Augustus Howe, acting as his deputy. Abercromby would attack Fort Carillon (later named Ticonderoga), where Montcalm had secured the Lakes Champlain and George corridor. Amherst's task was to complete the capture of Nova Scotia by taking the seaside fortress of Louisbourg. Forbes got the unenviable job of taking Fort Duquesne at the Forks of the Ohio. Forbes would be cutting a new road to the forks again and had both Braddock's and Washington's failures to avoid. However, the support infrastructure would be better this time, and he promised himself to be patient in the task.

Lord Loudoun's one major accomplishment was setting up a robust logistical system to support the obvious campaign lines. Along with the enhanced logistical capabilities came improved intelligence and movement security provided by Rangers and British regulars using newly adopted (by the British) woodcraft and irregular warfare techniques. Finally, Pitt removed the leadership regulations and funding issues that had so annoyed the colonial governments. The result was a surge of militia and recruits into the British regiments for use in the three campaigns. Along with the stronger footing of the land forces, Britain retained its naval superiority. The Royal Navy increased the number of ships and sailors under sail and committed a huge effort to seal off French ports and the Mediterranean. The result for New France was severe shortages of everything, including food. The Royal Navy and the British Army had developed a close working relationship and it would deliver huge benefits in $1758 .{ }^{20}$

As the 1758 campaign season opened in North America, the Englandlaunched portion of the Royal Navy campaign, led by Admiral Edward Boscawen, fought adverse weather conditions crossing the North Atlantic, so progress was slow. However, a sizable chunk of the Louisbourg expedition's troops and supplies, led by Captain Alexander Colville, Lord Colville of Culross, had been harbored in Halifax during an icy and miserable winter. He sent scouting ships to Louisbourg to set up watch in February 1758. A small French squadron arrived with some supplies to great fanfare at Louisbourg, though little was to follow, and this shipment was not nearly enough to sustain Louisbourg from the siege that was to come. Rear Admiral Sir Charles Hardy, as the vanguard of Boscawen's force, arrived in mid-March and took command of the Halifax force and began intercepting French ships headed for Louisbourg. Some French ships made it through to shore up New France, but bad weather, disease, and Hardy's harassment took a heavy toll. ${ }^{21}$

A complicating factor for the land forces was that they were coming from 
nearly every point around the British Atlantic, including Scottish Highlanders, Irish regulars, troops formally stationed in Hanover, English regiments, Royal Americans, and garrisoned troops in Nova Scotia. American Rangers were present, including companies from Rogers' Rangers, but led by his brother, James Rogers, because Robert Rogers was personally requested by Abercromby to assist with the Ticonderoga campaign. ${ }^{22}$ These troops had never trained together as amphibious forces, so Boscawen took the lead when he arrived off of Halifax on 9 May 1758. Boscawen formed a joint staff and set them to formulating the command and control, organization, and plans to deliver this motley force onshore in an orderly fashion. Boscawen had attended many of the strategic sessions with Pitt, Anson, and Ligonier in London and had more experience in land warfare than most Royal Navy officers, having begun his career as an engineer, so his understanding of the mammoth task in front of them pressed on him. With less than a month to land at Louisbourg, the amount of tactical planning and training that needed to occur was immense. Most British amphibious doctrine that would prevail for 50 years was developed off the coast of Halifax in May 1758. Force organization, signaling, synchronization, command handover, supply, disembarkation, flat boat management, artillery support-among many other concerns_-were all planned and coordinated in that month. ${ }^{23}$

Colonel Wolfe led the training of the troops on shore in the hilly terrain around Halifax with the focus on regaining unit integrity and command control once onshore. They also trained on siege techniques that were common in Europe, but rarely experienced in North America. Rangers, light infantry, and grenadiers were organized to land first and secure the landing zones, flanks, and routes off the beach. The concept of operation was to use these unique troops to secure a foothold, so the regular infantry could deploy quickly and provide a mass of firepower very early in the assault. The scale of the endeavor is impressive in the annals of military history. Historian Hugh Boscawen, a direct descendant of Admiral Boscawen, stated,

Fourteen regiments, artillery, and rangers-two-thirds of the British regulars in America - and the fleet were transformed into a cohesive expeditionary force in eighteen days in Halifax in May $1758 .^{24}$

On 28 May 1758, Admiral Boscawen's force departed Halifax with Amherst's force trained by Boscawen and Amherst's junior officers, including Wolfe. The entire operation had been planned and rehearsed without Amherst. Amherst's ship met Boscawen's fleet on the day it left Halifax. On the voyage up to Louisbourg, Amherst was thoroughly briefed and brought up to speed. Amherst was generally accepting of the plans he would have to execute, but did simplify some of the more complex plans onshore that James Wolfe had 
instituted. This did not please Wolfe, but he complied. The bulk of the fleet anchored around Louisbourg on 2 June 1758. Anxious to press the attack, Amherst sent reconnaissance landings to the proposed landing sites. Not everyone was happy with the landing sites, but local informants arrived to better brief the fleet and army. By 5 June, Amherst was ready to deploy but was forestalled by bad weather and fog that continued through 7 June. ${ }^{25}$

On the morning of 8 June 1758, after a little bit of dithering, but not enough to stop the operation, Amherst sent Wolfe and the lead units ashore. At the chosen landing site, French guns opened up on the landing forces with withering effect. Seeing the devastation, Wolfe called off the attack. However, several junior officers, including some of Robert's Rangers, broke off from the flotilla and rowed for a small but hidden part of the beach. With the luck that comes to forces prepared and led by confident officers, they found a sheltered cove to land. It was very small but was masked from the French positions. Wolfe waved the rest of his initial landing forces forward to the cove. After landing, Wolfe was able to turn the French flank and avoid a full-frontal assault on the originally chosen beach. The main force followed and secured the full beach within an hour. Boscawen's men supplied the land forces fully within four hours. Amherst landed and took charge of the force on land and set up a standard siege, beginning the methodical steps to reduce the fortress. The British also soon destroyed several French naval vessels that had stayed to support the fortress. With the landings secured and supplied, the reduction of Louisbourg was a mere formality of siege work during the next six weeks. The French finally capitulated on 27 July 1758. Although the siege followed European protocol, the massacre after Fort William Henry in 1757 led Amherst to deny the honors of war to the surrendered fortress. The French were taken prisoner and the Micmac and Abenaki warriors present were chased down and killed by Rangers from Massachusetts. ${ }^{26}$

At Fort Carillon (Ticonderoga), Abercromby had not been so lucky. Abercromby had approached the French fort carefully and landed south of the fort, but lost his highly respected second in command, Lord Howe, in an early skirmish. Abercromby hesitated a day and Montcalm took full advantage to reinforce his position with trenches and an abatis. ${ }^{27}$ An artillery barrage would have broken holes in the abatis and turned the splinters into thousands of tiny spears near the French line, but weak intelligence led Abercromby to attempt a full-frontal attack on the well-prepared French positions. The attack failed on 8 July 1758 with 2,500 British killed or wounded. Montcalm had lost 750 from a smaller force but was feeling vindicated in not using as many natives as before, therefore having better control and not experiencing atrocities. The battle had been fought in the traditional European manner, but Abercromby had choices that would have saved many of his men and driven the French farther north. 
Nothing more can be said to explain the battle. It was simply poorly led by a British general, again. ${ }^{28}$

Abercromby was very worried that Pitt would fire him immediately with the news of Fort Carillon. Pitt had little time to prove his radical and costly plan and would not tolerate weak leaders. Abercromby decided to launch a long sought but delayed plan to attack Fort Frontenac at the head of the Saint Lawrence into Lake Ontario. Frontenac was the linchpin of all of the lower forts in supplying the natives and French forces. Lieutenant Colonel John Bradstreet would lead the mixed force of 3,100 regulars, militia, and Iroquois that Sir William Johnson had recruited. Abercromby was not sure of the bold plan but knew that he needed to take action. He had not heard of Amherst's success at Louisburg yet and was very concerned for his job. Bradstreet had been a critical player in Loudoun's logistical buildup and was sure he could lead the mission to success by keeping the details secret until the last second and being bold in his execution, avoiding leakage to the French local natives.

On 12 August 1758, his batteau (canoes of Canadian design) and whaleboat force headed for Oswego along creeks, rivers, and Lake Oneida. At Fort Oswego, they turned north onto the open Lake Ontario to Fort Frontenac. Upon arrival, he landed on a small island and immediately conducted a reconnaissance of the fort and found it lightly defended. The garrison was full of supplies and was completely surprised by his arrival on the beach below the fort. On 28 August 1758, Bradstreet took Frontenac after a light defense by the small French force. He had no desire to take prisoners, so he let them free with personal possessions and a promise from the French commander to release an equal amount of British prisoners on his honor. Bradstreet's force loaded up their boats with booty and destroyed what they could not carry. In the span of 24 hours, one of France's most important supply forts had been reduced to ashes. Bradstreet had not lost a single man in the amphibious raid. Although not anywhere near the size of the Louisbourg amphibious operation, Bradstreet knew frontier logistics, picked people who trusted him, and knew how to keep the element of surprise from being compromised-three critical components of an amphibious operation. ${ }^{29}$

In Pennsylvania, Forbes was hacking his way through the wilderness throughout the summer of 1758 on his way to claim the French Fort Duquesne at the Forks of the Ohio. The Ohio native tribes such as the Shawnee, Delaware, and Mingo were still supporting the French but noticed the change in the strategic situation. French trade goods were becoming scarce and no fresh French troops were arriving due to the British naval superiority. The Ohio tribes made tentative approaches to Forbes along his way. Since July, 700 Cherokee from the southern colonies were already in attendance due to their need for colonial aid in their fights with the Creek and the Choctaw in the South. A severely ill 
Forbes eventually made it to Fort Duquesne at the Forks of the Ohio on 25 November 1758 only to find that the French had destroyed it and left. His methodical campaign while building relations with the Ohio tribes had paid off, and he had succeeded in taking the Forks of the Ohio where Washington and Braddock had failed. Other than river crossings, there had been no amphibious operations in Forbes's column, but the lessons of alliance building, planning, and logistical professionalism had paid off for the British. ${ }^{30}$

As 1758 closed out, the British had seemingly turned the tide of the war by capturing Louisburg, destroying Fort Frontenac, and securing the Forks of the Ohio. Abercromby had been a failure, but even after the defense of Fort Carillon, Montcalm had decided to move north to a stronger position. The Royal Navy was stronger than ever. The British Army had improved greatly since Braddock's defeat, but the improvement was not evenly spread yet. Relations with the Ohio tribes were better, Rangers were improving intelligence and movement security, and the critical coordination for large-scale amphibious operations had been developed, practiced, and executed in adverse conditions with great success.

As 1759 dawned, Pitt realized that Abercromby was not the man for the job of closing down the war in North America. Amherst was named his successor and Abercromby was sent back to Britain with a face-saving promotion to lieutenant general. After the great successes of 1758, including his own at Louisbourg, Amherst was eager to take advantage of the situation in 1759 and put together a plan to force the capitulation of New France. Forbes died from his illness in early 1759 but wrote stridently to Amherst to take his lessons about dealing with the tribes. Amherst learned much in 1758, but Forbes's prescient letters were not part of his education. Amherst was as arrogant as Braddock or Loudoun but took command when the strategic calculations of the tribes were changing. Wolfe chafed under Amherst's command and had gone back to Britain to lobby for the mission to take Quebec in 1759. Bradstreet was promoted to colonel but relegated back to his role as chief logistician for Amherst's army. ${ }^{31}$

During the winter of 1758-59, Pitt instructed Amherst to conduct an aggressive campaign season to end French power in North America. Amherst would lead the push up the New York lakes corridor to silence the twin threats of Forts St. Frederic (Crown Point) and Carillon (Ticonderoga). Major General James Wolfe, in an independent command, would deliver the assault on Quebec with 7,000 troops on 49 ships plus landing craft. To continue the chokehold on the French upriver forts, Fort Niagara would be secured. It was an ambitious plan that played to Britain's strengths and New France's weaknesses, but it would not be easy to root out a foe who knew the ground as well as the French knew the North American interior. The British also sought more native 
assistance, but their main accomplishment in this area was convincing the tribes around the eastern Great Lakes not to openly support the French. ${ }^{32}$

The massacres and general mayhem along the frontier that the tribes had caused with their French allies from 1755 to 1757 were still fresh in the minds of the British commanders. Both Amherst and Wolfe had shown little mercy when taking Louisbourg. They had given their Rangers free rein to wreak havoc on the neighboring settlements. By 1759, the British were in no mood to show the honors of war to an enemy who had treated them so carelessly from 1755 to 1757. Almost as a side project in the 1759 campaign, but one that was intended to send a message, Amherst unleashed his Rangers, led by Robert Rogers, to raid the Abenaki village of St. Francis between Montreal and Quebec. Using 17 whaleboats to cover most of the distance in miserable conditions, Rogers led his force to destroy the Abenaki base. The results of this raid were as horrific as anything that had happened to date, with the entire village being set fire and many casualties of the elderly, women, and children. The French had found and destroyed Rogers's camouflaged whaleboats during the raid, so the Rangers had a near disastrous exfiltration march back to friendly lines. By 1759, the British forces had fully adapted to North American frontier warfare, for better or worse. $^{33}$

Farther west, the Niagara campaign led by Indian Agent William Johnson had managed to keep most of the French allied tribes out of the fight. The British had moved from Fort Oswego along the shore of Lake Ontario and laid siege to Fort Niagara in early July but had to contend with a French relief force from the abandoned Fort Duquesne in the south. Johnson's Iroquois allies played a decisive role in the July 1759 battle at La Belle Famille, south of Niagara, by keeping the French-allied Iroquois out of the fight. With no further relief in sight, the French commander at Niagara surrendered on 25 July 1759. The loss of Fort Niagara was the final nail in the coffin for the French influence in the Ohio Valley. The British now controlled Lake Ontario with its supply chain to the interior. The Royal Navy controlled access to the Saint Lawrence from the sea from Louisbourg. By the fall of 1759, New France effectively existed only from Quebec to Montreal. The French faced the hard realization that many of the tribes they had relied on in the past were no longer at their service. However, if the British thought they had neutralized the native threat by separating the French from their indigenous allies, they would soon be disabused of this idea. The tribes of the Great Lakes realized that their old strategy of playing one European ally off the other would no longer be sufficient to maintain their independence. However, the British problems with the natives in 1763 were not yet to be realized in $1759 .{ }^{34}$

With the noose tightening on New France, General Montcalm pulled his French troops in close at Quebec, Trois-Rivieres, and Montreal to make a last 
stand. The French government had promised him more troops if he could hold out until the spring of 1760 . Whether this would have happened is debatable, as the French government was torn between fighting on the seas and in the colonies and doubling down on their land strength in Europe. This was the age-old strategic peer-power question of fighting to one's strengths or minimizing one's weaknesses. From 1755 to 1757 , the French had thought that their greatest weakness of a smaller population in North America could be mitigated with the help of the Great Lakes native tribes and a superior tradition of wilderness warfare. However, the British managed to improve their skills in wilderness warfare, amphibious operations, and native diplomacy in 1757-58. What the French had not been able to deal with was the Royal Navy's command of the sea. Meanwhile, the British had managed to improve their weakness in land power in Europe by allying with Frederick II, king of Prussia, in 1756. British money and limited troops with Prussia's military superiority held France and Austria at bay. With the holding of Hanover and its Prussian alliance, the British were able to deliver a greater volume of troops and supplies by sea to North America and deny that ability to France. ${ }^{35}$

However, if General Wolfe could not take Quebec, the great British gamble might not have come to the resounding victory that it did. Throughout the summer, Amherst worried about the Quebec campaign led by Wolfe. By late July, he had hoped that Wolfe had taken Quebec, or at least laid siege to it, but no such word had come. Instead, word of atrocities being committed by Wolfe's troops in the communities around Quebec filtered down. Wolfe could not entice Montcalm to a fight, so he had resorted to terrorizing the area around Quebec in a desperate bid to get Montcalm out of the fortress at Quebec. Newly inspired by the great success of Louisbourg, Wolfe conducted a near continuous set of amphibious operations along the Saint Lawrence around Quebec to harry the French. With each amphibious deployment, the British became better at it, but none could lure Montcalm from the fortress Quebec. The heavily defended city seemed nearly impregnable if its defenders stayed close. However, the Royal Navy were reconnoitering the river channels and testing the French batteries of Quebec, which provided cover for other operations and much-needed intelligence about the river itself. By late July 1759, the lack of information from Wolfe and the slipping away of the summer campaign season made Amherst more tentative in approaching Montreal for fear of meeting a large French force that might have been freed if Wolfe had been defeated. Unbeknownst to him yet, Fort Niagara had been taken by William Johnson and Wolfe was making plans for a make or break amphibious operation near Quebec. ${ }^{36}$

Had Amherst realized Wolfe's true situation in July and August 1759, he would have had even more misgivings. Wolfe had lost much of the command support of his brigadier generals in executing the village terror operations. They 
had honorable reputations in Europe to uphold and the nature of the warfare around Quebec was nasty. Additionally, Wolfe had fallen gravely ill and feverish, likely from kidney stones and rheumatism irritated by stress. With steep cliffs, artillery command of the river, and seemingly no suitable amphibious landing locations, the area around fortress Quebec was more challenging than Duquesne, Frontenac, Louisbourg, or Niagara. As for troops at Quebec, the French effectively outnumbered the British two to one. As the summer ebbed away, Wolfe became desperate. Would his legacy be death in the field from a weak constitution and dishonor from war crimes? The French remained hopeful that they could hold out until the winter, when the British advantages would be mitigated and the French advantages improved by the Canadian winter. By late August, Wolfe knew his chances of decisively engaging Montcalm were slipping away. He decided on an incredibly risky plan of landing upriver from Quebec on a small shingle beach named L'Anse au Foulon at the base of steep cliffs. He risked all for a final roll of the dice. Had he failed, it would have been one of the great disasters of British military history. Luckily, his boldness paid off. ${ }^{37}$

The Royal Navy had used its time around Quebec wisely and had sound intelligence of the channels, coves, and shoals of the Saint Lawrence. The naval force was commanded by Vice Admiral Sir Charles Saunders on the Saint Lawrence and the landing forces were led by Captain James Chads. Future Royal Navy legends such as James Cook amassed an enormous amount of knowledge about the tides, moonrises, currents, and peculiarities of the river in overnight reconnaissance missions. ${ }^{38}$ Through practice, training, and routine planning, the British were unrivaled in their tactical and operational prowess in amphibious operations. During the night of 12-13 September 1759, they had anchored at Cap Rouge, nearly 10 miles above their chosen landing point. The French troops on land led by Montcalm acolyte, Louis-Antoine de Bougainville, kept an overwatch. ${ }^{39}$ The British conducted a diversionary maneuver farther downriver near the northeast side of Quebec where they had attempted an amphibious assault previously. With the French fooled by the anchorage upstream and the diversion downstream, the British boarded shallow draft boats that had been designed and delivered rapidly after the Rochefort debacle. They rode the ebbing tide and landed near L'Anse au Foulon, although the swift tide had taken the lead elements too far down. ${ }^{40}$ Shortly thereafter, not finding the wagon path that had been reconnoitered earlier, the British light infantry scaled the bluffs and destroyed a small, surprised French detachment behind an abatis, facing down the path, near the top. The top of the bluff was at the western tip of a mile-wide plateau known as the Plains of Abraham, only two miles from Quebec. ${ }^{41}$ The British had used all of their hard-won knowledge about amphibious operations from Rochefort and Louisbourg to deliver an incredibly difficult operation in the early hour darkness. 
Overnight, Montcalm still thought the northeastern diversion was the main landing force and the Plains of Abraham force was the diversion. Bougainville's overwatch force near Cap Rouge feared the worst when morning came and they saw the British fleet and all of their landing craft sailing downriver to the landing site. Once Montcalm saw the situation for what it was, he had little time to decide what to do. Wolfe spared no time in getting the rest of his force to the plateau and deployed across the width of it. He posted Rangers and natives in the woods along the flank and began sniping at the forming French defenses. Montcalm decided to deploy the majority of his forces and face Wolfe immediately. Although Montcalm held a numerical advantage, much of his force was militia and allied tribes. These troops had been spectacular on the frontier, but this would be a traditional European engagement that would require discipline and precise maneuvers. These advantages belonged to Wolfe, whose force was almost entirely comprised of British regulars. Montcalm, fearing Wolfe's force would continue to grow, decided to advance to contact. The disorder in the French ranks began to show immediately with an uneven line and undisciplined movements. The British held fast and fired volleys in strict discipline. The British fire was far better controlled and more deadly. As French discipline broke down completely, the British fixed bayonets and charged forward and chased the French force back to the walls of Quebec. The two sides had lost an almost identical amount of men. Although Wolfe and Montcalm were dead, the British commanders pressed the advantage and reinvigorated the siege. Quebec surrendered on 17 September 1759. Wolfe's great gamble had succeeded. ${ }^{42}$

Having knowledge of the British success at Fort Niagara in August, but not knowing the outcome of Wolfe's actions and his death at Quebec until 18 October 1759, Amherst had hesitated in the late summer and not advanced on Montreal, consolidating at Crown Point. The French forces had already retreated and reorganized at Montreal during the winter of 1759-60. Given the situation in Niagara and Quebec, Amherst could be pleased with the progress, but all was not well. A Cherokee uprising in the South was underway where the British had few troops stationed. More worrisome were rumors that the Seneca, and tribes allied with them on the British southwestern flank, were making noise about resisting British rule of their homelands. Although 1759 had become the "miraculous year" for the British with victories against the French around the world, the French still held an important part of Canada and were well prepared to defend it. If the French could rally their erstwhile native allies, the British could be in for another difficult period. ${ }^{43}$

However, also unknown to Amherst late in 1759, another British victory would seal the French defeat in North America. At Quiberon Bay, off the Brittany coast, the last French operational squadron in the Atlantic was destroyed by the Royal Navy. The defenders of Montreal would have little to no reinforce- 
ments in 1760. As the 1760 campaigning season began, Amherst dispatched a force to the Cherokee homelands to ruthlessly quell the Cherokee rebellion and secure the rear. The fighting with the Cherokee would drag on for more than a year, but it was never a serious threat to Amherst's plan for Montreal. The force with which the Cherokee war was handled may have given the Seneca and the other Great Lakes tribes pause in their consideration of an uprising as well. Therefore, with his rear and flanks secure, Amherst focused on Montreal and the remaining French forces. In the winter of 1760, the French had counterattacked Quebec, but had failed to take it. When the news of Quiberon Bay arrived and they realized that the spring would not bring supplies and reinforcements from France, they fell back to Montreal to await the inevitable British assault. Amherst's plan was to use the rivers to attack from the east, west, and south. Although, these were not large-scale amphibious assaults like Wolfe's in 1759 , they were amphibious operations in support of the three prongs. Working methodically but successfully to convince the French-allied tribes to abandon the French, it took him the entire 1760 campaign season to move three columns on Montreal. However, by early September, Amherst had obtained the French surrender and New France effectively ceased to exist. ${ }^{44}$

Although the Seven Years' War would continue in a near stalemate in Europe through 1760, Britain had won North America from its primary rival. Additionally, the Royal Navy's dominance at sea meant North America, the Caribbean (1761-62), and India (1757-61) were no longer commercial and strategic assets to the French. ${ }^{45}$

The Spanish had entered the war with the French in early 1762. In early June 1762, the British would conduct another textbook amphibious assault against the Spanish at Havana, Cuba. Royal Navy vice admiral Sir George Pocock; British Army lieutenant general George Keppel, the Earle of Albermarle; and Commodore Honorable Augustus Keppel conducted a near flawless amphibious assault that built on the experience of the great operations at Louisbourg and Quebec. The coordination of naval gunfire in support of the landings was especially notable. However, Albermarle would be slow to finish the job once on land and Britain lost an enormous number of troops due to disease. ${ }^{46} \mathrm{How}-$ ever, the tide of the war was firmly in Britain's favor at this point. By late 1762, the French and Spanish were negotiating peace. The Treaty of Paris in 1763 was a resounding victory for the British and secured the First British Empire. ${ }^{47}$

However, not all was well in North America. It had taken the British longer than they liked to put down the Cherokee uprising. The Great Lakes tribes noticed that Britain was sending troops back to Europe and would not be able to conduct the large-scale operations in the interior as they had a few years earlier. Diplomacy with the tribes was still very difficult for the British leadership. By 1763, the Great Lakes area was engulfed in war again as a confederacy of tribes 
attacked undermanned British forts on the frontier. Pontiac's War was a direct consequence of the French and Indian War and its aims. The British managed to end that war, but with concessions that would enrage the British-American colonists. Another fire, though long smoldering, had been lit in North America. France had to lick their wounds, but the French Navy would reemerge to bedevil the British in the American Revolutionary War a mere 15 years later. The French Army would hound the British, and everyone else, all over Europe 25 years later. The British and French rivalry would continue for another century. ${ }^{48}$

\section{Conclusion}

Britain's strength at sea was not always a foregone conclusion. France did rebuild its navy after the French and Indian War and use it to a much greater effect during the American Revolutionary War. However, Britain's insistence on linking the Royal Navy to its core strategy in the French and Indian War, while also improving in other areas, was decisive. Although not continual, this concept of land and naval coordination was so important to Britain that a century and a half later British statesman Sir Edward Grey would say, "The British Army should be a projectile to be fired by the British Navy." ${ }^{99}$ The strategic battle between France and Britain followed a familiar pattern of great powers deciding whether to reinforce strengths or minimize weaknesses, depending on their opponents, allies, and situations. An important but mundane point has to be made to ensure that we do not go too far into the weeds; British colonists in North America outnumbered their French counterparts 33:1 and had better geography to supply and support themselves. However, that fact was also true at the beginning of the war when New France drubbed British and colonial forces regularly.

Although amphibious operations were ubiquitous, both sides used them in different ways. France generally used small-scale riverine and lake amphibious operations to deliver combat power, often made up of irregular forces. Britain also learned to conduct these smaller-scale amphibious operations with light troops. However, Britain was far more effective in using large-scale lake, riverine, and seaborne amphibious operations to land large quantities of troops at strategic locations. The decisive difference in North America was the British Army's willingness to improve itself and learn from its earlier mistakes. Almost from a standing start, they grew and, in some cases, mastered frontier warfare. The same can be said for the rising competence in logistical concerns in the wilderness and in amphibious operations. Their competence in frontier war and logistics combined with their willingness to use the Royal Navy's professionalism in amphibious operations meant Britain was able to create and sustain an incredibly flexible force. In modern terminology, Britain became a truly joint force by mastering strategic operational planning, utilizing mass in support of 
strategic objectives, and enforcing the terms of unity of effort between naval and land forces. From 1758 onward, Britain was able to deliver decisive combat power to almost any point on the globe. The Bay of Fundy, Louisbourg, Frontenac, Fort Duquesne, and Quebec campaigns were turning points at each stage of the French and Indian War. Without them and the combined force amphibious operations that enabled them, the war in North America probably could not have been won. ${ }^{50}$

\section{Notes}

1. Colin S. Gray, "History for Strategists: British Seapower as a Relevant Past," in Seapower: Theory and Practice, ed. Geoffrey Till (Portland, OR: Frank Cass, 1994), 7-11.

2. Geoffrey Till et al., Maritime Strategy and the Nuclear Age (London: Palgrave Macmillan, 1982), 224-25, https://doi.org/10.1007/978-1-349-17464-5.

3. Gray, "History for Strategists," 20-22.

4. King George's War is the name given to operations in North America.

5. Fred Anderson, Crucible of War: The Seven Years' War and the Fate of Empire in British North America, 1754-1766 (London: Faber and Faber, 2000), 124-32.

6. Richard White, The Middle Ground: Indians, Empires, and Republics in the Great Lakes Region, 1650-1815 (Cambridge, UK: Cambridge University Press, 1991), 50-93.

7. Howard H. Peckham, The Colonial Wars: 1689-1762 (Chicago: University of Chicago Press, 1964), 120-38.

8. David A. Clary, George Washington's First War: His Early Military Adventures (New York: Simon \& Shuster, 2011), 44-90.

9. Anderson, Crucible of War, 86-93.

10. William M. Fowler Jr., Empires at War: The French and Indian War and the Struggle for North America, 1754-1763 (New York: Walker, 2006), 77-86.

11. Francis Jennings, Empire of Fortune: Crowns, Colonies \& Tribes in the Seven Years War in America (New York: W. W. Norton, 1988), 160-63.

12. Peckham, The Colonial Wars, 156-60.

13. Anderson, Crucible of War, 238-39; and Ian K. Steele, Warpaths: Invasions of North America (New York: Oxford University Press, 1994), 197-206.

14. John Grenier, The First Way of War: American War Making on the Frontier, 1607-1814 (Cambridge, UK: Cambridge University Press, 2008), 115-45.

15. Voltaire, Candide (New York: Boni \& Liveright, 1918).

16. David Syrett, "The Methodology of British Amphibious Operations during the Seven Years and American Wars," Mariner's Mirror 58, no. 3 (1972): 269-80, https:// doi.org/10.1080/00253359.1972.10658666; and N. A. M. Rodger, The Command of the Ocean: A Naval History of Britain, 1649-1815 (London: Penguin Books, 2006), 264-72.

17. Hugh Boscawen, The Capture of Louisbourg, 1758 (Norman: University of Oklahoma Press, 2011), 51-57.

18. Maj Matthew J. Cahill, USA, An Unassailable Advantage: The British Use of Principles of Joint Operations from 1758-1762 (Fort Leavenworth, KS: Army Command and General Staff College, 2016), 10-15.

19. Anderson, Crucible of War, 387-90.

20. Walter L. Dorn, Competition for Empire: 1740-1763 (New York: Harper \& Row, 1965), 346-50; and Anderson, Crucible of War, 232-36.

21. Boscawen, Capture of Louisbourg, 102-17.

22. Burt Garfield Loescher, The History of Rogers' Rangers (San Mateo, CA: Genesis, 1969), 27-28.

23. Cahill, An Unassailable Advantage, 17-19.

24. Boscawen, Capture of Louisbourg, 150.

25. Boscawen, Capture of Louisbourg, 152-63. 
26. Sir Julian Stafford Corbett, England in the Seven Years' War: A Study in Combined Strategy, vol. I (London: Longmans, Green, 1918), 305-22; Fowler, Empires at War, 167-72; and Boscawen, Capture of Louisbourg, 163-70.

27. The term abatis refers to an obstacle or barricade of trees with bent or sharpened branches directed toward an enemy or a barbed wire entanglement used as an obstacle or barricade against an enemy.

28. Jennings, Empire of Fortune, 363-64.

29. John Bradstreet, An Impartial Account of Lieut. Col. Bradstreet's Expedition to Fort Frontenac: To Which are Added a Few Reflections on the Conduct of that Enterprize, and the Advantages Resulting from Its Success (London: T. Wilcox, W. Owen, M. Cooper, and Mr. Cooke, 1759), 1-45; and Jennings, Empire of Fortune, 364-67.

30. Matthew C. Ward, Breaking the Backcountry: The Seven Years'War in Virginia and Pennsylvania, 1754-1765 (Pittsburgh, PA: University of Pittsburgh Press, 2003), 157-85.

31. Anderson, Crucible of War, 307-11.

32. Anderson, Crucible of War, 317-24

33. John F. Ross, War on the Run: The Epic Story of Robert Rogers and the Conquest of America's First Frontier (New York: Bantam Books, 2011), 235-52; and Grenier, The First Way of War, 138-40.

34. David Dixon, Never Come to Peace Again: Pontiac's Uprising and the Fate of the British Empire in North America (Norman: University of Oklahoma Press, 2005), 52-72; and Fowler, Empires at War, 195-96.

35. Dorn, Competition for Empire, 357-62.

36. Simon Foster, Hit the Beach!: Amphibious Warfare from the Plains of Abraham to San Carlos Water (London: Arms and Armour Press, 1995), 11-21; and Anderson, Crucible of War, 348-52.

37. Peter D. MacLeod, Northern Armageddon: The Battle of the Plains of Abraham and the Making of the American Revolution (New York: Vintage Books, 2017), 19-36, 125-37; and Anderson, Crucible of War, 344-52.

38. Syrett, "Methodology of British Amphibious Operations," 270-72; and Foster, Hit the Beach!, 16-20.

39. Louis-Antoine de Bouganville, Adventure in the Wilderness: The American Journals of Louis Antoine de Bougainville, 1756-1760, ed. and trans. Edward Pierce Hamilton (Norman: University of Oklahoma Press, 1964).

40. Syrett, "Methodology of British Amphibious Operations," 273; and MacLeod, Northern Armageddon, 24.

41. Fred Anderson, The War that Made America: A Short History of the French and Indian War (London: Penguin Books, 2005), 198-202.

42. Corbett, England in the Seven Years' War, vol. I, 459-70; MacLeod, Northern Armageddon, 138-60; Foster, Hit the Beach!, 17-20; and Anderson, The War that Made America, 202-6

43. Fowler, Empires at War, 195-97.

44. Julian S. Corbett, England in the Seven Years' War: A Study in Combined Strategy, vol. II (London: Longmans, Green, 1907), 105-88; Bougainville, Adventure in the Wilderness, 325-26; and Anderson, Crucible of War, 387-409

45. Corbett, England in the Seven Years' War, vol. II, 119-40.

46. David Syrett, "The British Landing at Havana: An Example of an Eighteenth-Century Combined Operation," Mariner's Mirror 55, no. 3 (1969): 325-31, https://doi.org/1 0.1080/00253359.1969.10659492; and Cahill, An Unassailable Advantage, 29-35.

47. Dorn, Competition for Empire, 357-69.

48. Dixon, Never Come to Peace Again, 244-75; and Jennings, Empire of Fortune, 438-46.

49. Adm John Arbuthnot Fisher, Baron, Memories (London: Hodder and Stoughton, 1919), 18.

50. Richard Harding, Seapower and Naval Warfare, 1650-1830 (Abingdon, UK: Taylor \& Francis Group, 1999); Foster, Hit the Beach!, 16; and Cahill, An Unassailable Advantage, 35-39. 


\title{
The Ottomans, Britain, Sectarianism, and the Sudanese Army 1899-2019
}

\author{
Jack Vahram Kalpakian, PhD
}

\begin{abstract}
Using a historical and a partially institutional approach, this article examines the relationships between religious politics and imperialism in the formation of organized military forces in Sudan. It examines the policy of using paramilitary forces, as well as its ideological sources. The article argues that the Popular Defence Forces and other paramilitaries are a threat to the regular Sudanese Army. The article also addresses some of the human rights issues in (North) Sudan and concludes with thoughts concerning its ongoing revolution.
\end{abstract}

Keywords: Sudan, Egypt, Sudanese Armed Forces, Popular Defence Forces, British Empire, Ottoman Empire, religious politics

\section{Introduction}

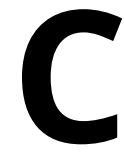

urrently undergoing extreme political turbulence and a revolution, $\mathrm{Su}$ dan is a deeply troubled state. The ongoing Sudanese revolution represents a methodological challenge to this work, which the author hopes can be addressed through an examination of history. The united Sudan was once the largest state in Africa and had a population in excess of 40 million at the time of its partition in 2011. Since its independence on 1 January 1956, united Sudan was engaged in civil wars for all but 9 years of its 55 -year existence. Sudan gave up its monopoly on violence to private militias and forces

Jack Vahram Kalpakian holds a doctorate in international studies from Old Dominion University, Norfolk, VA. He specializes in security issues, water, and the Middle East/North Africa as well as East Africa. Since August 2001, Kalpakian has been teaching at Al Akhawayn University in Ifrane, a Moroccan university following the American tertiary education pattern. Originally from Sudan, Kalpakian is a native speaker of Arabic. 
that have their own methods and objectives. Specifically, the origins of the decline can be traced back to the decisions of the Sudanese military to take over power in 1958 and to pursue politics of forced Arabization and Islamization. These two policies were part of Sudan's attempt at creating a unified national identity independent of Britain and at the same time acceptable to Britishinfluenced Egypt. They were implemented shortly after independence in part as a response to the Torit mutiny, heralding the First Sudan Civil War. Curiously, these were not policies that came as a result of votes in an elected parliament but rather as edicts from a military dictator emerging from an army rooted in Ottoman military tradition.

The Sudanese Army remains one of the least-studied institutions in international affairs, and aside from a short piece on demobilization, disarmament, and reintegration, there are no recent articles on the Sudanese Army on digital academic libraries for journals and monographs or other scholarly research databases. ${ }^{1}$ The focus here is on its decline, but there is more to the Sudanese Army than mere decline. First, we must consider its historical context, which spans from the army's creation in the nineteenth century to its loss of the monopoly of legal violence to paramilitary forces in the late twentieth century. Critical within this discussion is the role of General Ibrahim Abboud's regime, a key transitional period during decolonization, in creating a permanent sense of crisis between the country's Arab and Muslim communities on the one hand and non-Muslim and non-Arab peoples on the other. Second, we must explore the history and operations of the Popular Defence Forces (PDF) and other progovernment paramilitaries to properly frame the erosion of the Sudanese state. This article will conclude with some thoughts concerning the reversal of the erosion of the Sudanese state and how such a reversal might be realized.

This article is not an effort to enter the debates concerning fourth generation warfare, the revolution in military affairs, or some of the other discussions that have dominated security and military studies in Western capitals during the last 20 years. It is also not an attempt to enter into debates concerning the role of today's Turkey in Sudan or about the origins of the various pro-regime militias. The focus here is the Sudanese Army and how its loss of the monopoly on violence has damaged it and the state. Suffice it to say that many of these discussions were shaped by the rather sudden Western introduction to Middle Eastern violent extremism after the 11 September 2001 attacks. Cold War strategies, such as the perceived need to use religious conservatives against leftists in the region, permitted extremist ideologies to expand. Methodologically, this article uses history by comparing two points of time: one related to the 1958 Abboud coup and the other related to the formation of the PDF. The country changed dramatically due to these two events and, in many ways, these choices sealed the fate of a united Sudan. The two successor states are locked in 
what appears to be a near permanent war with their respective lesser-integrated regions.

\section{The Sudanese Defence Forces: An Anglo-Egyptian Creation with Ottoman Roots}

The Ottoman Empire's Khedivate of Egypt conquered the independent states of Sennar, Metamma, Dongola, and eventually Darfur between 1825 and 1879, creating a united satellite state it called "the land of the blacks"-Sudan. Ottoman laws continue to inform life in Sudan to this day. In particular, its legacy affects customs surrounding religious community membership and what one is permitted or forbidden to do outside of any given particular religious community. ${ }^{2}$ As such, it is important to emphasize that the Sudanese Army's ultimate origins are found not in the 1925 organization of the separate Sudan Defence Force, but in the Sudanese battalions of the Egyptian Ottoman Khedival Army. ${ }^{3}$

The British establishment of the Sudan Defence Force within the British Army simply meant the transfer of Sudanese units in the Egyptian Army into a British structure, with both an autonomous identity and a "native" uniform pattern. The Ottoman nature of the force is further underlined not only with the continuation of the use of the Turkish ranks but also with the force's continued reliance on Egyptian officers. Before 1914, Sudanese soldiers owed their ultimate allegiance to the sultan of the Ottoman Empire, like their Egyptian colleagues; consequently, the Sudanese Army's roots are thoroughly Ottoman. It is important to address the significance of the Ottoman legacy. After all, the modern Turkish Army shares these same roots and was for decades a secularist, modernist force deeply invested in its alliances with the West. However, readers should use caution when examining the implications of the word Ottoman and its meaning. Historically, and with a few notable exceptions, the armed forces of the Ottoman Empire reflected a single religious confession and were legitimated on the basis of religion. These Ottoman traditions were practiced in both Egypt and Sudan. There, the military service was called al jihadiya-conscription and volunteer military service were seen as a fulfillment of a religious duty by young men. So strong was the affiliation between religion and military that the Egyptian soldiers would forcefully conscript southern Sudanese animists into their ranks and convert them to Islam. ${ }^{4}$ It was into this sort of military that General Abboud began his military career.

\section{Toward a Separate Sudanese Force}

The status of Sudan and of its military forces was peripheral, as long as the British and Ottoman Empires were at peace and in a de facto alliance. The real trouble came with the relationship between Egypt, an autonomous dominion within the Ottoman Empire, and the British Empire. For all intents and pur- 
poses, the British Empire controlled Egypt between 1882 and 1892, but it did so without a formal takeover of the country. Britain ruled Egypt and was allied with the Ottoman Empire as a legacy of the Crimean War (1853-56). Consequently, the divergence between de facto and de jure colonial rule could be papered over until the Ottomans went to war on the side of Germany in 1914. As a result, the British Empire formally took over Egypt and made it into a protectorate, then an independent sultanate, and finally an independent kingdom under its former vice regal dynasty. Anomalously, Sudan was a dependent state under joint British and Egyptian (and thereby formally Ottoman) sovereignty. Sudan was a dependency of a dependency-Egypt - as well as a dependency of the British Empire. ${ }^{5}$ Therefore, it was logical that its military forces should fit into a structure separate from those of the Egyptian Army. The change in Egypt's status ultimately informed the status of Sudanese military forces. Nevertheless, a more pressing reason to separate the Sudanese units in the Egyptian Army was the revolt of the White Flag League in 1919. The revolt was led by a southern Sudanese lieutenant in the Egyptian Army, Lieutenant Ali Abd alLatif. The revolt reflected a unique form of Nile Valley nationalism that hastened British plans to separate Sudanese forces. Ibrahim Abboud had been commissioned as a lieutenant in the Egyptian Army the previous year, meaning that he was contemporaneous with Lieutenant Abd al-Latif. Despite his rebellious colleagues, Abboud remained a reliably pro-British officer until his 1958 coup. ${ }^{6}$

\section{From Establishment to Independence}

The new Sudan Defence Force emerged as a 4,000-man unit in 1925, bolstered with both British and Sudanese-Egyptian officers. The disappearance of Ottoman Egypt, the Egyptian decision not to treat Sudan as a series of regular Egyptian provinces, the White Flag League revolt, and finally the presence of a dual sovereign made it necessary to have a separate Sudanese military with formal allegiance to the Egyptian sovereign but integrated within the British Army. During World War II, the Sudanese Defence Force proved a useful ally in the British East African campaign against Italy, which controlled Eritrea and occupied Ethiopia. Sudan shouldered the costs of its own war against Italy in East Africa and was able to make compensatory gifts to Britain for the intervention of the Royal Air Force against the Italian Air Force in Eritrea and Ethiopia. ${ }^{7}$ After the war, the position of the British Empire had significantly declined and inevitable change was awaiting the country. The next steps in Sudan's history were made more complex by the unusual presence of two external sovereigns sharing the territory of what had, since 1899 , amounted to a vassal state.

In line with the preexisting British policy of co-opting Muslim elites, there was no attempt to seriously alter the nature of the Sudan Defence Forces during 
the 30 years between 1925 and the Torit mutiny in 1955. Britain sought to prevent the use of Islam as a tool against it by co-opting Muslim Sufi leaders. These Sufi leaders included the descendants of the Mahdi, whose Ansar Sufi movement formed the basis of the Umma (National) Party. ${ }^{8}$

It also sought to establish Islam as the religion of Sudan as early as 1901 . There was a policy of treating the south, with its animist population, differently. Christian churches were allowed to operate there but not in the north. While Sudan had Christians and animists in its population, it was to become a Muslim state. The second British governor general of Anglo-Egyptian Sudan, Sir Frances Reginald Wingate, established a Muslim religious scholars board to advise him:

This Board constitutes an advisory board to which Government is able to refer questions of a religious nature. . . . The Board has been appointed with the object of enabling Government to deal with these religious questions, as, ostensibly, the approved agents of orthodox Mohammedanism, rather than as a Government acting on its own initiative. The attitude of Government towards the religion of the Country is visibly strengthened in being supported in its measures by the highest orthodox religious opinions in the land. ${ }^{?}$

Far from marginalizing Islam in Sudan, the British Empire enshrined it at the center of the state. The Sudan Defence Forces were inevitably also affected, with Egyptian and Sudanese Islamic clerics functioning in them as well. But, Britain's time in the Nile Valley was very limited. In 1952, Egypt experienced a coup that brought a clique of Arab nationalist officers into power. Led by Gamal Abd al-Nasser, the officers eroded Egypt's alliances with Britain. This put the Sudanese leadership in a crisis. Clearly the British, Egyptian, and Sudanese visions for the future of the country were contradictory. To complicate matters further, the southern Sudanese feared that the departure of the British would mean the integration of the country into Egypt and the handover of command to northern Sudanese officers. ${ }^{10}$ Subsequently, the southern troops of the Sudan Defence Force mutinied in Torit in 1955 against the transitional Azhari government. $^{11}$

\section{Decolonization: Egypt versus Britain}

Sudanese independence came as a result of deep coordination between Britain, represented by Governor General Sir Alexander Knox Helm, and the incoming Sudanese government led by Chief Minister Ismail al-Azhari. The laws governing Anglo-Egyptian Sudan gave the elected chief minister the powers of the governor general in the latter's absence. Helm took a vacation and told al-Azhari to unilaterally declare independence on 1 January 1956, with the assurances 
of British recognition. Most British troops had left Sudan in November 1955, and Helm had partially suppressed the Torit mutiny by issuing pardons to mutineers. However, not all mutineers accepted the pardon, and so the insurgency continued after independence.

Furthermore, the coordination between al-Azhari and Helm effectively excluded Nasser, who retaliated by continuing his policy of intervention and attempts to subject Sudanese interests to those of Egypt. A central concern for Nasser was the allocation of Nile waters along lines that favored Egypt. Using a combination of economic sanctions and support for sympathizers in Sudan itself, Nasser destabilized Sudanese politics and undermined al-Azhari, who was replaced by Abdullah Khalil. ${ }^{12}$ The Sudanese government found itself in a stalemate. The traditional method that pre-independence elites had used to secure their own interests as well as the country's was to try and reverse the colonialists' game of divide and rule. They would do this by exploiting the preexisting divisions between Egypt and Britain. In the ensuing crisis, the Sudanese military conducted its first entry into politics by overthrowing the elected government and placing General Abboud into power. ${ }^{13}$

\section{Making Religion the Focus of the First Civil War}

Abboud's approach to the civil war subtly altered the nature of the Sudanese state in unanticipated ways that may have directly led to the partition of the country. For Abboud, the civil war with the Southern rebels did not have a territorial or national dimension. He gave the conflict a religious and an ethnic dimension. If we consider the relatively peaceful and heterogeneous makeup of Ottoman Sudan, homogeneity was not a necessity. Abboud isolated and excluded southern troops and officials, including those who were loyal to a united Sudan. He also tried to break ties with the southern elite and the southern populations by attempting to impose Islam. He did this through a policy of Christian missionary expulsion and forced Islamization. For example, southern students were forced to formally convert if they wished to receive public education. These measures intensified the civil war and backfired terribly. Instead of converting the south's traditional religionists and Christians to Islam, Abboud's policies ironically strengthened the Roman Catholic Church, which subsequently became a locus of southern resistance to his policies. ${ }^{14}$

Lieutenant [sic] General Ibrahim Abboud became the first Sudanese leader to conceive and implement programs of Islamization and Arabization in the Southern Sudan. . . . But the various Southern Sudanese ethnic groups continued to resist conversion to Islam, and by the time the Abboud administration ended in October 1964, only a small number of Southern Sudanese people had converted to Islam. ${ }^{15}$ 
The mutiny and the ensuing civil war have become objects of academic dispute, particularly in terms of the importance of religion, but this article will not enter those discussions. In many ways, the forced Islamization policies of the late Ottoman Empire and Abboud's policies in the south betray a striking kinship. The idea that the state should reflect Islam and that non-Muslims are not full citizens and thereby not entitled to equal treatment is a late Ottoman idea that finds no clear precedent in previous Islamic states, including the Ottoman Empire itself before the Hamidian era. General Abboud was overthrown by a popular uprising in 1964 . However, the civil war that he fomented lasted for another eight years and claimed about half a million lives. In 1972, Gaafar Mohamed el-Nimeiri's regime signed the Addis Ababa Agreement and ended the conflict for a period.

\section{The Popular Defence Forces}

Government precedents for the Popular Defence Forces include the colonial-era Gideons and Gazelle Forces, as well as the armed sections of the Umma National Party, the political arm of the Mahdist Ansar Sufi movement, which generally reflected a conservative-nationalist and democratic orientation. These antecedents can rightly be called partisan forces. Traditionally, partisans were irregular forces dependent on regular armies for support, arms, and training. These forces have been used extensively, particularly by poorer states and actors throughout world history. The German Landwehr, the Confederate and Union rangers, and tribal levies of various states are all examples of such a precedent. Under normal circumstances, these irregular forces do not threaten the structure of the state. Partisans, while not as professional and extensively trained as the regular forces, are embedded in the political and military chains of command of the state. They typically reflect the state's policies and are subject to its military justice and accountability systems. The Sudanese Popular Defence Forces, however, fed the erosion of Sudanese state power, as exemplified in the career of a former commander, Sheikh Musa Hilal. To understand how this transpired, this section discusses the formation of the PDF, their training, involvement in human rights violations, and transformation into an opposing force to the very government they were formed to protect.

\section{Giving Away the Monopoly on Violence: Establishing the Popular Defence Forces}

The immediate antecedents of the PDF in Sudan were tribal militias recruited by Sudan's Umma National Party government during the mid-1980s. These partisan forces were used as part of the war effort against the Sudan People's Liberation Army (SPLA) in areas where northern and southern populations were intermixed (e.g., South Kordofan). The regular Sudanese Armed Forces (SAF) 
regarded them with suspicion and argued against the government's support of these forces. A central theme of this article is that their concerns proved to be correct in the long term:

On 20 February 1989 SAF commander-in-chief General Fathi Ahmed Ali, issued an ultimatum signed by 150 senior officers that called on the government to give greater support to the regular armed forces. . . . The so-called Popular Defence Forces bill, recommended by the committee, was proposed to the Constituent Assembly but resoundingly rejected. ${ }^{16}$

After the June 1989 coup, the new government set aside the institutional objections of the military. The deeply ideological new regime was composed largely of junior officers led by a brigadier general, Omar al-Bashir. The new government supported the idea of the PDF, and by November of the same year, the Sudanese parliament adopted the Popular Defence Forces Act. The legislation came at the recommendation of the Revolutionary Command Council for National Salvation, which remains the name of Bashir's government. The act formally established the tribal militias within Sudanese law. ${ }^{17}$ Pro-government tribal and party militias were then merged into the Popular Defence Forces and naturally brought their particular local agendas into the force. ${ }^{18}$

\section{Training}

The current government slowly imposed the ideology of Sudan's branch of the Muslim Brotherhood, then called the National Islamic Front (NIF), into all aspects of the government. The NIF elite, led by Bashir and the late Hassan al-Turabi, would extend this ideology into the PDF after purging the older military elites. In contrast to the old guard in the military who preferred negotiated outcomes, the NIF preferred a military solution followed by the forced Islamization of the country's Christians and animists. Given that the Sudanese Muslim Brotherhood used anti-Western narratives in Arabic throughout its history in its appeals to the Sudanese public, Bashir and al-Turabi could not openly align Sudan with Western powers.

Their takeover also occurred before the collapse of the Soviet Union, so it was not possible to turn to the Eastern Bloc, due to the ideological distance related to the state atheism of Eastern Bloc Communist countries. Therefore, the new regime was limited in its allies to fellow Islamic states. These states included Iran, who helped its new partners in Sudan with paramilitary force training. Iranian cooperation and training began in December 1991, following a state visit by the Islamic Republic of Iran's president, Ali Akbar Hashemi Rafsanjani. Iranian Islamic Revolutionary Guard Corps (Pasdarn) training camps were set up in north Sudan, and all Sudanese males resident in the country older than 
age 16 became eligible for service. Although military service remained voluntary, the state used the Iranian model developed in the war against Iraq, wherein mosques and television programs promoted self-sacrifice through military service. $^{19}$

\section{Human Rights Violations}

With many of its units originating from tribal formations, the Popular Defence Forces became quickly embroiled in Sudan's interethnic and intertribal conflicts. They violated human rights on a vast scale in the early years of the PDF. The violence was most extreme in the Nuba Mountains region and the Darfur region. Those targeted included non-Arab tribes, and in the case of the Nuba Mountains, the local Christian community

In addition to the burning of villages and the disappearance of civilians, a large-scale plan of forcible relocation was implemented by the government. Tens of thousands of Nuba are now scattered in small camps all over northern Kordofan. Many other thousands were taken hundreds of miles from home and abandoned. The scale of the killings and relocations reached the level of genocide. In October 1993, First Lieutenant Khalid Abdel Karim Salih, who was in charge of security in Kordofan and was a personal bodyguard to the governor of Kordofan (who is also his brother) from May 1992 to February 1993, made a statement in a press conference in Bern, Switzerland. He announced that, during a seven-month period, the army and the PDF had killed 60,000-70,000 Nuba. He stressed that these ethnic-cleansing operations made no distinction between Muslims and Christians. Churches and mosques, missionary centers, and Quranic schools were all shelled indiscriminately. ${ }^{20}$

The violence in the Nuba Mountains took an unusual turn. In traditional Islamic thinking, it is unfathomable for a Muslim government to shell and destroy mosques. However, the NIF government was no traditionalist Islamic government. In its own narrative, the rejection of its authority was tantamount to apostasy, and in its conception of Islam, that was a crime deserving of severe punishment. Mosques in the Nuba Mountains jihad were desecrated by government troops, who covered them with graffiti, instructing Muslims to come and pray in the government garrisons, destroying zakat (tithe) grain, and tearing up copies of the Qur'an. ${ }^{21}$

The government's "equal" treatment of Muslims and Christians in the Nuba Mountains was in line with its ideology. It was neither Westphalian nor a reflection of military needs. If Sudan's problems had a colonial origin at all, they more closely fit late Ottoman imperialism rather than any other colonialism. A similar pattern quickly emerged in Darfur:

In late September, a U.S. official reported that 574 villages had been

destroyed and another 157 damaged since mid-2003. Satellite images 
show many areas in Darfur burned out or abandoned. The majority of the attacks have occurred in villages where the rebels did not have an armed presence; Khartoum's strategy seems to be to punish the rebels' presumed base of support-civilians_-so as to prevent future rebel recruitment. ${ }^{22}$

A sad debate emerged about the events in Darfur, and its focus was the applicability of the term genocide to the problem. Unfortunately, the presence of African Union-United Nations Hybrid Operation in Darfur (UNAMID) troops and International Criminal Court (ICC) warrants against the suspected authors of the massacres did not help end the crisis. The 2006 Darfur Peace Agreement and the vote on whether the region would be composed of one or several states within Sudan did not end the crisis either. The very same militias that supported the government during the war in the south against the SPLA and later against the uprising in Darfur created a domain independent of government control in central Darfur.

\section{Musa Hilal}

The Sudan Liberation Movement and Army, led by Suliman Arcua Minnawi, was one of the signatories of the 2006 Darfur Peace Agreement. As part of the transition, he was appointed a special assistant to the president in Sudan. That appointment, and its associated benefits, may have led the government's own supporters to look at rebellion as a means to gaining money and wealth. In late 2013 and early 2014, Musa Hilal, a leader in Darfur's pro-government Arab militias, formed his own political movement, the Sudanese Awakening Revolutionary Council (SARC). Hilal, who is accused of being a war criminal, argued that the Sudanese government is failing to meet its promises to supporters. Through its spokesman, Ahmed M. Babiker, SARC placed the blame on the government for Darfur's ills and argued that it is seeking "a civic and democratic order under the rule of law." ${ }^{23}$

Hilal's discourse correlated with his new role as an independent actor. In particular, he adopted the narrative of the Darfur rebels, specifically the Justice and Equality Movement, which shares some Islamist roots with him. His openness toward working with the secular Sudan Revolutionary Front (SRF) was also a major shift. His troops clashed with militias that remained under the government's direct command and his overall stance caused confusion among the Darfurian armed opposition, who had fought his forces during the war in Darfur. ${ }^{24} \mathrm{He}$ argued that he would like to see Darfur Arabs and non-Arabs reconcile and the SARC aims to speak for all the ethnic and tribal communities of the region. ${ }^{25}$ By January 2017, the government accused Hilal of rebellion. It endorsed the United Nation's assessment that Hilal and his armed group are 
looting Darfur's gold ores and smuggling gold. Hilal's group had charged artisan prospectors a per-bag fee for ore mined and had benefited from the withdrawal of the regular Sudanese Army from the Jebel Amir area to consolidate direct control over the gold-rich region. The Sudanese Army troops withdrew after Hilal's groups began skirmishes with them. Hilal controlled about 400 gold mines. ${ }^{26}$ Despite the clear collusion of some officials in moving Hilal's gold to the United Arab Emirates through the airport in Khartoum, along with the Central Bank of Sudan's money laundering, then-Minister of Interior Ismat Abdel Rahman Zein al-Abdin spoke against Hilal and his group. He accused Hilal of using foreign forces to undermine government authority in Darfur and called for military intervention against him. ${ }^{27}$ In November 2017, the Sudanese government moved against Hilal. He was taken into custody, but some of his followers were released in June 2018. ${ }^{28}$

\section{The Army and the Militias}

Given the historical record discussed above, the Sudanese Army was fully aware of the dangers that the paramilitaries posed to its role in the state and tried, as an institution, to prevent their legalization. Nevertheless, political and ideological considerations triumphed at the expense of institutional legitimacy, minority identities, and traditional Sudanese expressions of Islam. During the First Sudanese Civil War (1955-72) before and after Abboud, the fighting was conducted by regular Sudanese troops on both sides. Even the rebels were mutineers from the SDF. The situation remained much the same until the formation of tribal, pro-Umma National Party units that eventually became the Popular Defence Force with the advent of the Second Sudanese Civil War (1983-2004). These new forces were not military and were not subject to the regulations that govern the SAF. In addition to the Popular Defence Forces, a variety of affiliated tribal and ideological militias appeared on the government's side. On the various rebels' sides, the forces simultaneously became more diverse; they were no longer composed of the original mutineer units. The war was characterized with the appearance of hitherto unseen formation in independent Sudan's military of northern Muslim rebel paramilitary forces, the SRF, which was drawn largely but not exclusively from non-Arab communities in Darfur, southern Kordofan, and the southern Blue Nile Province. The SRF lacks direct origins in the regular military and is unusual in terms of being a Muslim force that espouses secularism.

Despite the importance of sectarianism, much of the religious fervor that accompanied the Sudanese civil wars was staged and not sincere. For example, the "celebrations" of martyrdom that the PDF held for their deceased members at homes of their next of kin were outside Sudanese Arab and Muslim cultural funerary traditions and helped bring about the marginalization of the force. 
While it may have been permissible for Musa Hilal to lead his tribal forces against other tribes and ethnic communities in acts of self-defense or existential wars for water access during droughts, it was unthinkable that the AbbalaHilal's tribal confederation-would have endorsed seizure of townships and gold mines for the purpose of Hilal's personal enrichment. The case of Musa Hilal should serve as a warning to any country considering handing out weapons to militia forces.

\section{Conclusion: Implications for Revolutionary Sudan}

Convenient policies of arming paramilitary forces, tribal and otherwise, helped contain the SPLA, but the long-term cost to Sudan was realized by SARC and its activities. Worse yet, the slow erosion of the Sudanese state is creating space for external actors keen to use Sudan as a base for their own wars against enemies, both real and imagined. If Sudan is to avoid the fate of Somalia and Mali, the state apparatus must reassert itself. To do so, the militias must disappear as soon as possible and the state army must again become the sole legitimate instrument of violence within its societies. While it remains to be seen whether such a refounding is possible, Sudan needs to evaluate the relationship between the state and religion. The events in Darfur and the troubles caused by Musa Hilal strongly suggest that religious homogeneity, when imposed by the state or achieved through partition, is unlikely to solve the fundamental problem of nation building. Ironically, a professional, all-national army may be a better foundation for nation building than outdated Ottoman ideas of exclusivity and reserving the military for a single religious community.

The present revolutionary movement in the current rump state of "Northern" Sudan is backed by a diverse array of social forces. A rump state is the remnant of a much larger state. The revolutionaries targeted the headquarters of the Sudanese military because they understood that the power of the Bashir/ Muslim Brotherhood regime rests in its control of the military. The removal of Bashir by the military does not solve some of the problems the revolutionaries are facing. First, there is a dilemma concerning religion and the state. Broadly speaking, the revolutionaries are demanding what they name a civil state, which in practical terms implies a separation of religion and the state in a Sudanese context. In essence, they are demanding the reversal of a policy instituted by General Wingate decades ago. Second, they face a dilemma concerning the military's monopoly on legal violence as required by the civil state; the current military is Islamist not only due to Wingate and Abboud but also due to its takeover by the Muslim Brotherhood, along with nearly all civic, economic, and political structures in the country in 1989. Finally, the Sudanese revolutionaries would not have been able to dethrone Bashir without the army. The National Congress Party, an offshoot of the Sudanese Muslim Brotherhood, 
controlled the internal security apparatus and had independent militias as well. Without the military, the revolution would not have displaced Bashir. However, the military embodies values at odds with those demanded by the revolutionaries. The recent crackdown embodied that division, and it remains a serious problem facing the revolutionaries, the army, and the country as a whole.

\section{Notes}

1. Mathew LeRiche, "Sudan, 1972-1983," in New Armies from Old: Merging Competing Militaries after Civil Wars, ed. Roy Licklider (Washington, DC: Georgetown University Press, 2014).

2. Erik Jan Zürcher, "The Ottoman Conscription System, 1844-1914," International Review of Social History 43, no. 3 (December 1998): 437-49, https://doi.org/10.1017 /S0020859098000248.

3. Ahmed El Awad Mohammed, "Militarism in the Sudan: The Colonial Experience," Sudan Notes and Records, no. 61 (1980): 15-26.

4. Yusuf Fadl Hasan, "Some Aspects of the Arab Slave Trade from the Sudan 7th-19th Century," Sudan Notes and Records, no. 58 (1977): 85-106.

5. Helen Chapin Metz, ed., Sudan: A Country Study (Washington, DC: GPO for the Library of Congress, 1991). See, in particular, the chapter "The Anglo-Egyptian Condominium, 1899-1955."

6. Yunan Labib Rizk, "The Sudan Defence Force," Al-Ahram Weekly On-line, no. 520 (February 2001).

7. K. D. D. Henderson, "The Sudan and the Abyssinian Campaign," African Affairs 42, no. 166 (1943): 12-20, https://doi.org/10.1093/oxfordjournals.afraf.a093324.

8. John O. Voll, "The British, The British, The 'Ulamâ', and Popular Islam in the Early Anglo-Egyptian Sudan," International Journal of Middle of East Studies 2, no. 3 (July 1971): 212-18, https://doi.org/10.1017/S0020743800001100.

9. Reginald Wingate as cited by Voll, "The British, the 'Ulamâ', and Popular Islam in the Early Anglo-Egyptian Sudan," 215.

10. Edgar O'Ballance, The Secret War in the Sudan: 1955-1977 (London: Faber and Faber, 1977), 41.

11. Anthony Nutting, Nasser (New York: E. P. Dutton, 1972), 110-13.

12. Jack Kalpakian, Identity, Conflict and Cooperation in International River Systems (Aldershot, UK: Ashgate, 2004), 60-63.

13. Nutting, Nasser, 284-87.

14. Scopas S. Poggo, "General Ibrahim Abboud's Military Administration in the Sudan, 1958-1964: Implementation of the Programs of Islamization and Arabization in the Southern Sudan," Northeast African Studies (New Series) 9, no. 1 (2002): https://doi.org /10.1353/nas.2007.0002.

15. Poggo, "General Ibrahim Abboud's Military Administration in the Sudan," 71.

16. Jago Salmon, A Paramilitary Revolution: The Popular Defence Forces (Geneva, Switzerland: Small Arms Survey, Graduate Institute of International Studies, 2007), 13.

17. Report on Fact-Finding Mission to Cairo, Khartoum and Nairobi: Human Rights Situation, Military Service, and Entry and Embarkation Procedures in Sudan (Copenhagen: Danish Immigration Service, 2001).

18. Behind the Red Line: Political Repression in Sudan (New York: Human Rights Watch, 1996), 274-75.

19. Salmon, A Paramilitary Revolution, 17-19.

20. Mohamed Suliman, "The Nuba Mountains of Sudan: Resource Access, Violent Conflict, and Identity," in Cultivating Peace: Conflict and Collaboration in Natural Resource Management, ed. David Buckles (Ottawa, Canada: International Development Research Centre and World Bank, 1999), 215.

21. Alex de Waal and A. H. Abdel Salam, "Islamism, State Power and Jihad in Sudan," in 
Islamism and Its Enemies in the Horn of Africa, ed. Alex de Waal (Bloomington: Indiana University Press, 2004), 73.

22. Scott Straus, "Darfur and the Genocide Debate," Foreign Affairs 84, no. 1 (2005): 126, https://doi.org/10.2307/20034212.

23. "Janjaweed Leader Defects from NCP, Establishes New Political Movement," Sudan Tribune, 5 January 2014.

24. “Musa Hilal's 'Awakening': Khartoum's Worst Nightmare?," Sudan Tribune, 22 April 2015.

25. "Ex-Janjaweed Leader Calls for Reconciliation in Darfur," Sudan Tribune, 21 July 2016.

26. Letter Dated 4 December 2015 from the Panel of Experts on the Sudan Established Pursuant to Resolution 1591 (2005) Addressed to the Chair of the Security Council Committee Established Pursuant to Resolution 1591 (2005) Concerning the Sudan (New York: United Nations Security Council, 2016), 39-45.

27. "Minister Calls for Military Intervention in N. Darfur Gold Mines," Sudan Tribune, 5 January 2017.

28. "Sudan Releases 20 Partisans of Darfur Tribal Leader Musa Hilal," Sudan Tribune, 12 June 2018. 


\title{
The Expeditionary Implications of a Populist Grand Strategy
}

\author{
Bruce I. Gudmundsson, PhD
}

\begin{abstract}
The rise of a new form of populism challenges the assumptions underlying the grand strategy of the United States and thus the types of activities that the operating forces of the United States Marine Corps may be called on to perform.
\end{abstract}

Keywords: populism, grand strategy, clash of civilizations, migration

$F$ or the world as a whole, the years between 1947 and 2017 were times of enormous change. In those seven decades, the population of the planet trebled, and, at the same time, grew much richer, much better connected, and, in terms of heritage, allegiance, and culture, far less European. The same is not true of the 70 years that preceded 1947. Outside of a handful of highly developed countries, all but one of which were chiefly inhabited by people of European descent, the experience of people living in 1947 differed little from that of people who were alive in 1877 . For the operating forces of the Marine Corps, the experience of the last 14 decades has been the exact opposite of that of the vast majority of human beings. That is to say, all of the great metamorphoses experienced by Marines on active service during the course of the past 140 years had either been completed or, at the very least, were well underway before the passage of the National Security Act that gave the Marine Corps its current form. ${ }^{1}$

Bruce I. Gudmundsson, who retired from the Marine Corps Reserve in 1997, currently serves as an advisor to the Marine Corps Tactics and Operations Group (MCTOG). In his free time, he maintains The Military Instructor (teachusmc.blogspot.com), a family of websites devoted to the use of decision games, podcasts, and other innovative methods in military education and training. 
One cause of the curious pattern of change of the past 140 years has been the timing of technological transformation. Between 1877 and 1947, inventions of immediate interest to Marines, those associated with delivery of cargo, people, projectiles, and messages, appeared with reliable rapidity. Between 1947 and the present, nearly all of the items of equipment introduced into the inventory of Marine operating forces have been improved versions of the devices that they replaced. Thus, while a Marine of 1877 would have stared in amazement at the weapons and equipment fielded in 1947, a Marine of the latter year would easily recognize much of the ordnance presently in use and most means of locomotion. Moreover, if they were in the habit of reading magazines such as Popular Mechanics, they would have quickly made sense of such exceptions to this rule, such as the Bell Boeing V-22 Osprey and antitank guided missiles, the direct antecedents of technologies that already existed, albeit as prototypes. ${ }^{2}$

Another contributor to the slow evolution of Marine Corps' operating forces between the end of the Second World War and the present day has been the absence of any significant alteration to the grand strategy of the United States. That is to say, whatever their position on the political spectrum, the vast majority of Americans, and nearly all those in positions of national influence, have acted in ways consistent with the presumption that the paramount purpose of the foreign and defense policies of the United States ought to be the protection, proliferation, and perfection of liberal democracy throughout the world. ${ }^{3}$ Indeed, so powerful was this "liberal universalism" that, on occasions when American politicians found it necessary to make alliances with illiberal regimes or support the overthrow of democratically elected governments, such measures were invariably defended on the grounds that they would, in the long term, serve the eventual triumph of political, economic, and social systems similar to our own. ${ }^{4}$

All of the essential elements of liberal universalism can be found in the penultimate paragraph of the best-known work one of its most famous avatars, Francis Fukuyama. Writing at the end of the Cold War, Fukuyama made use of an unmistakably American metaphor, that of a nineteenth-century wagon train:

Rather than a thousand shoots blossoming into as many different flowering plants, mankind will come to seem like a long wagon train strung out along a road. Some wagons will be pulling into town sharply and crisply, while others will be bivouacked back in the desert, or else stuck in ruts in the final pass over the mountains. . . The wagons are all similar to one another: while they are painted different colors and are constructed of varied materials, each has four wheels and is drawn by horses, while inside sits a family hoping and praying that the journey will be a safe one. The apparent differences in the situations of the wag- 
ons will not be seen as reflecting permanent and necessary differences between people riding in the wagons, but simply a product of their different positions along the road. ${ }^{5}$

One contributor to the crumbling of the long-standing American consensus in favor of liberal universalism has been the painfully obvious failure of the Herculean project to plant liberal democracies in various parts of the Muslim world. Another is the growing influence, in academic and intellectual circles, of systems of thought, whether postmodern or antimodern, that reject the philosophical underpinnings of liberal universalism. ${ }^{6} \mathrm{~A}$ third reason for the decline of American faith in the ubiquitous utility, all-inclusive applicability, and eventual triumph of liberal democracy is the growing popularity among politically active people in the United States of a new kind of populism.

Also known as "populist nationalism," "national populism," and "the new nationalism," the populism of the twenty-first century rests on the premise that the paramount purpose of a state is the preservation of a particular people. ${ }^{7}$ In some countries, such as Poland and Hungary, the identity of the people in question stems from a common ethnic heritage. In others, such as France and the United States, the definitive population of a country owes its existence to what might be called civic ethnogenesis. That is, membership in such a people has more to do with commitment to a particular set of institutions and ideals than biological descent from the creators of those things. ${ }^{8}$

Proponents of populism imagine a "people," however formed, as a profoundly persistent phenomenon, "a partnership not only between those who are living, but between those who are living, those who are dead, and those who are to be born."' Because of this, they assign a great deal of value to the transmission of traditions from one generation to another, the preservation of patrimony, and the avoidance of any measure, however tempting in the short term, that places the long-term well-being of the people at risk. This perspective also preserves populists from the temptation to engage in enterprises aimed at altering the fundamental features of societies other than their own. ${ }^{10}$

Present-day populists are often described, by friend and foe, as "nationalists." While there is a great deal of truth in this designation, the conservative character of populism causes its champions to differ from the nationalists of earlier eras in one important respect. In the two centuries between the French Revolution and the end of the Cold War, nationalists often sought to increase the possessions, populations, and prestige of the states built around their nations, even if it meant the incorporation of substantial numbers of foreigners into their respective realms. In sharp contrast to these nationalists, the populists of the past four decades have often proved willing, and sometimes even eager, 
to sacrifice size, whether of territory or population, on the altar of common descent.

To a large degree, the great change in the preferences of nationalists stems from a number of broad developments in the world at large. On a planet in which war between states is both less frequent and much more capital-intensive than it used to be, the independence of a people is much less dependent on the ability to put large numbers of soldiers into the field. At a time in which talent, capital, and goods move among states with an unprecedented degree of freedom, a smaller state can be as economically viable as a larger one. In particular places, the power of these global developments has been increased by local events. For example, the forced transfers of a population that took place at the end of the Second World War did much to increase the degree of ethnic homogeneity in the populations of Poland and Hungary, while the breakup of Czechoslovakia and Yugoslavia replaced multinational, polyglot polities with states that were, at once, substantially smaller and far more homogeneous. ${ }^{11}$

The high value that populists place on homogeneity correlates strongly with deeply held beliefs in the uniqueness of national cultures, the specificity of national situations, and the degree to which practices, policies, and predilections reflect the peculiar experience of particular peoples. This, in turn, leads easily to profound pessimism about the prospects of projects aimed at transplanting political institutions from one country to another. Thus, for example, populists can be expected to reject, as inevitably futile, efforts to build liberal democracies on the wreckage of endogenous dictatorships. Such efforts, they tell us, may result in regimes that are better or worse than the ones that they replaced, but cannot lead to situations in which the people who make up these governments replace the values, habits, and assumptions of their respective countries with those of an alien nation.

The embrace of the uniqueness of national cultures does not, however, prevent populists from acknowledging, appreciating, and, indeed, celebrating the existence of communities larger than nation-states. On the contrary, the rejection of the one-size-fits-all universalism inherent in so many competing philosophies often leads populists to a belief that the world is divided into distinct global civilizations, each of which is separated from the others by considerable chasms of purpose, presumption, and practice. We thus find populists in Europe, the Americas, and the Antipodes making frequent mention of the membership of their respective nations in a common civilization, that of the West. Similarly, populists in Turkey, Indonesia, and Malaysia, such as Turkish president Recip T. Erdogan, see no inherent contradiction between their service as champions of the definitive nationalities of their respective states and their enthusiasm for the well-being, expansion, and ultimate triumph of Islam. ${ }^{12}$ 
To date, no Anglophone populist has proposed a taxonomy of global civilizations as complete as the one made famous by Samuel P. Huntington. ${ }^{13}$ Nonetheless, populists writing in English agree on three important points. First, they believe that the differences that distinguish Islam from the West are much greater than those that distinguish the component peoples, states, and movements of those two polycentric civilizations from one another. Second, they view China as an entity that is, at once, both a civilization and a state. Third, they see Russia as a special case, a place in which the hybrid character of the dominant culture makes possible both closer ties to the Western world and the embrace of alternate identities. ${ }^{14}$

There will, in all likelihood, be times when enthusiasm for the well-being of a multinational civilization will run afoul of the powerfully parochial propensities of populism. Nonetheless, the correlation between populism and a strong sense of civilizational solidarity is so strong that, even in nations as large as the United States, there is little danger of isolationism. Rather, if the opinions of prominent populists are any guide, it is far more likely that a populist United States will find itself serving as the hegemon of an informal alliance of Western states. Thus, while the Marines of a populist America will spend far less time in places inhabited by non-Western peoples, they may spend more time along the frontiers that separate the territory and waters of the West from parts of our planet that belong to other civilizations.

Of the three aforementioned propositions, the one that promises to effect the greatest alteration in the grand strategy of the United States, and thus the employment of America's Marines, is the idea of the persistent differences that distinguish the common culture of the West from that of Islam. To those who accept this precept, no amount of nation building will change the fundamental character of the peoples, polities, and practices of the Muslim world. Rather, the best that America can do when engaging entities that belong to this civilization is to provide them with incentives to refrain from doing us harm. This means that, on the rare occasions when Marines go ashore in such places, their visits will be brief and their purposes punitive. When, in the course of doing this, Marines happen to topple a government, they will do so with the expectation that any regime might follow will have much more in common with its predecessor than it does with any of its counterparts in the West.

The punitive expeditions sent into Muslim lands by a populist American government would bear a strong resemblance to the first campaign that U.S. Marines conducted in the Islamic world. In 1805, when First Lieutenant Presley Neville O'Bannon and his seven Marines crossed the Sahara, captured the fortress of Derna, and imposed peace in Tripoli, they did so to inflict pain on the prince who ruled there, to convince him to release American hostages, and to ensure that neither he nor any of his successors engaged in any future acts of 
piracy against vessels flying the Stars and Stripes. While this operation involved alliances with local leaders, one of whom sought to deprive the aforementioned monarch of his throne, any change of rulers that might have resulted from the operation would have been entirely incidental. ${ }^{15}$

In and of themselves, retributive raids will require few changes in the organization, armament, or training of the operating forces of the U.S. Marine Corps. Rather, the range of Marine Air-Ground Task Forces (MAGTFs) that the Corps has been employing since the 1960s possess both the capabilities and the mentality associated with the successful conduct of punitive expeditions. The same, however, cannot be said for the other sorts of missions that are likely to arise in a world in which a populist American government engages Islam as a global civilization - those that will ask Marines to deal with the phenomenon of Muslim migration.

Viewed through a populist lens, the movement of large numbers of people from one country to another poses a threat as great as many kinds of military operations. Similarly, those who stress the differences among global civilizations often point to the phenomenon of "migration jihad" as a means by which Islam can expand its influence, its population, and, ultimately, the territory under its control. ${ }^{16}$ Because of this, a populist government of the United States will, in all likelihood, undertake operations designed to prevent seaborne migrants from moving inland and facilitate their rapid repatriation. One can, for example, imagine a situation in which vessels containing Muslim migrants attempt to discharge their passengers on an American beach. In such a scenario, the Department of Homeland Security might ask the Department of Defense for help in establishing a cordon around the landing beach, setting up camps to house the migrants, and keeping the peace in those temporary settlements. While the military organizations best suited for this work would be military police units of the United States Army and Army National Guard, there might well be situations in which, for reasons of time, distance, and availability, the Pentagon will call on the Marine Corps to provide this sort of aid to the civil power.

One can also imagine situations in which Marines assist with the repatriation of people who, merely by remaining in the places where they were born, find themselves on the wrong side of a civilizational divide. Such situations, which might result from changes in borders, the movements of other peoples, or the demographic decline of the groups in question, might cause a populist government of the United States to attempt to help the people in question find a safe haven in the Western world. While such service would be more congenial to the Marines involved than the duties associated with the expulsion of unwelcome guests, it would require similar capabilities. To put things another way, in a world in which the United States embraces a populist grand strategy and, as a result, follows the logic of the "clash of civilizations," Marines may well find 
themselves establishing temporary cordons around large groups of civilians, protecting them from a variety of hostile parties, and ensuring they are able to reach their intended destinations.

In addition to providing security, Marines conducting these large-scale "noncombatant evacuation operations" would also be called on to fill gaps in the services provided by more specialized organizations. While any attempt to provide a definitive list of such work is necessarily doomed to failure, Marines can reasonably expect to be called on to assist with the movement of people and supplies, participate in information operations, and cooperate with people from a wide variety of occupational, organizational, and civilizational backgrounds. In other words, in addition to a set of skills peculiar to the management of migration, repatriation operations will require the same sort of polyvalence that has long been associated with success in complex emergencies.

Reduced to its essence, the way that a populist America engages Islam will be shaped by the absence of a central authority strong enough to compel sustained cooperation within that civilization. Thus, while various actors from the Muslim world will seek to conquer new territories, respond to threats posed by outsiders of various kinds, and avenge wrongs — both real and imagined — inflicted upon their coreligionists, they will not be able to do so in a coordinated fashion. When dealing with Islam, the United States, and, by extension, its Marines, will be faced with a chaotic series of autonomous outbursts of energy, enthusiasm, and enterprise.

The same is not true for the way that a populist United States will have to deal with China. Where the solidarity of Islam is largely a matter of the heart, that of Chinese civilization is founded, framed, and buttressed by an extraordinary degree of political cohesion. ${ }^{17}$ Whenever Marines interact with people acting on behalf of China, they will be engaging China as a whole. This, in turn, means that whenever Marines confront their Chinese counterparts, they will be obliged to weigh the risk of escalation against the price of backing down.

The ideal way to prepare for the challenge of high-stakes, small-scale standoffs with China is the provision of a great deal of vicarious experience in the resolution of crises of this sort. The cost of mistakes, however, will be such that many senior leaders will attempt to exercise close supervision over any American forces that come close to clashing with their Chinese counterparts. Indeed, the prospect of such confrontations will lead some to propose the replacement of the traditional Marine Corps approach to command with a form of restrictive control. Fortunately, the experience of encounters with the chaotic champions of Islam will provide lots of ammunition for Marines who will argue that this sort of micromanagement is the "exception that proves the rule" of such practices as the promotion of initiative and leading from the front. ${ }^{18}$ 
In dealing with both China and Islam, a populist United States will rely on Russia to guard much of the border that separates the West from the territory of those two civilizations. At the same time, America will have to take measures to ensure that the military capabilities needed to fulfill this task will not be used in ways that threaten the well-being of the unambiguously Western states of Eastern Europe. For American politicians, this policy will require the clear, consistent, and persistent explanation of the definitive dualism of the place of Russia within Western civilization. For Marines, support for such a policy will take the form of frequent "show the flag" visits to European nations located along the western border of Russia.

There is, of course, far more to the world than Russia, Islam, and China. A populist America will have to devise policies for dealing with India, Africa, and Latin America, as well as places such as the Antipodes and the "Southern Cone" of South America that might be described as "exclaves of Western civilization." An attempt to predict such policies, however, is beyond the purposes of this article. Indeed, even if all of the predictions made in the course of the preceding pages prove false, and the grand strategy of the United States takes a form different from the one described, people interested in the operations of landing forces will, from time to time, want to ponder the relationship between the way that Americans make sense of the world and the things that they ask their Marines to do.

\section{Notes}

1. The National Security Act of 1947, Pub. L. No. 253 (1947) laid out an organizational framework for those agencies of the United States government that are chiefly concerned with defense, intelligence, or foreign policy.

2. For brief descriptions of experiments with tilt-rotor aircraft in the years before 1947, see Martin D. Maisel et al., The History of the XV-15 Tilt Rotor Research Aircraft: From Concept to Flight (Washington, DC: NASA History Division, National Aeronautics and Space Administration, 2000), 6-8. For an accessible description of early antitank guided missiles, see John Weeks, Men Against Tanks: A History of Anti-Tank Warfare (New York: Mason Charter, 1975), 152-69.

3. For a brief and highly sympathetic description of liberal universalism, see Francis Fukuyama, "The End of History?," National Interest, no. 16 (Summer 1989): 3-18.

4. For the classic expression of the argument that the promotion of liberal democracy in the long term sometimes required short-term cooperation with forces that were neither liberal nor democratic, see Jeane J. Kirkpatrick, "Dictatorships and Double Standards," Commentary 68, no. 5 (November 1979): 34-45.

5. Francis Fukuyama, The End of History and the Last Man (New York: Free Press, 1992), 338-39.

6. For an examination of the fragmentation of liberal universalism, see Paul Edward Gottfried, Multiculturalism and the Politics of Guilt: Toward a Secular Theocracy (Columbia: University of Missouri Press, 2004).

7. For competing definitions of populism, see Roger Eatwell and Matthew Goodwin, National Populism: The Revolt Against Liberal Democracy (London: Penguin, 2018), 44-57, 78; Stephen R. Turley, The New Nationalism: How the Populist Right is Defeat- 
ing Globalism and Awakening a New Political Order (Newark, DE: Turley Talks, 2018), 10-19; and Francis Fukuyama, "The Rise of Populist Nationalism," in The Future of Politics (Zürich: Credit Suisse, 2018), 7-13.

8. For an overview of the large role played by immigrants in the French population and the process of assimilation, see Cicely Watson, "Recent Developments in French Immigration Policy," Population Studies: A Journal of Demography 6, no. 1 (July 1952): 3-38, https://doi.org/10.1080/00324728.1952.10415552. For the broader process of building civic nationalism, see Eugen Weber, Peasants into Frenchmen: The Modernization of Rural France, 1870-1914 (Stanford, CA: Stanford University Press, 1976).

9. Edmund Burke, Reflections on the Revolution in France (London: J. Dodsley, 1790), $143-44$.

10. For a brief taxonomy of populism that distinguishes between populism and demagoguery, see Victor Davis Hanson, “The Good Populism," New Criterione 36, no. 10 (June 2018): 4.

11. For a brief account of the forced population transfers that took place in Eastern Europe at the end of the Second World War, see Joseph B. Schechtman, "Postwar Population Transfers in Europe: A Survey," Review of Politics 15, no. 2 (1953): 151-78, https:// doi.org/10.1017/S0034670500008081. For descriptions of the movements that took place at the end of the Cold War, see, among others, Jean-Paul Sardon, "Demographic Change in the Balkans since the End of the 1980s," Population: An English Selection 13, no. 2 (2001): 49-70; and Milica Z. Bookman, "War and Peace: The Divergent Breakups of Yugoslavia and Czechoslovakia," Journal of Peace Research 31, no. 2 (1994): 175-87, https://doi.org/10.1177/0022343394031002005.

12. For a biography of President Erdogan that places his career within the larger context of Turkish politics, see Soner Cagaptay, The New Sultan: Erdogan and the Crisis of Modern Turkey (London: I. B. Tauris, 2017).

13. For a précis of this taxonomy, see Samuel P. Huntington, "The Clash of Civilizations," Foreign Affairs 72, no. 3 (Summer 1993): 22-49. For a book-length treatment, see Samuel P. Huntington, The Clash of Civilizations and the Remaking of World Order (New York: Simon and Schuster, 1996).

14. For a recent discussion of global civilizations from a populist point of view, see Ernesto Henrique Fraga Araújo, "Trump e o Ocidente" [Trump and the West], Cadernos de Politica Exterior [Foreign Policy Notebooks], Year III, Number 6 (Second Semester 2017): 323-58. For the three articles that introduced the "clash of cultures" thesis to populists in the English-speaking world, see William S. Lind, "Western Reunion: Our Coming Alliance with Russia?," Policy Review, no. 49 (Summer 1989): 18-21; William S. Lind, "North-South Relations: Returning to a World of Cultures in Conflict," Current World Leaders 35, no. 6 (December 1992): 1073-80; and William S. Lind, "Defending Western Culture," Foreign Policy, no. 84 (Autumn 1991): 40-50, https:// doi.org/10.2307/1148780.

15. For an account that looks at this operation from the point of view of the ruler of Tripoli, see Seaton Dearden, A Nest of Corsairs: The Fighting Karamanlis of Tripoli (London: John Murray, 1976). For American perspectives, see, among others, Addison Beecher Colvin Whipple, To the Shores of Tripoli: The Birth of the U.S. Navy and Marines (New York: William Morrow, 1991); Joseph Wheelan, Jefferson's War: America's First War on Terror, 1801-1805 (New York: Carroll and Graf, 2003); Joshua E. London, Victory in Tripoli: How America's War with the Barbary Pirates Established the U.S. Navy and Shaped a Nation (Hoboken, NJ: John Wiley and Sons, 2005); and Richard Zacks, The Pirate Coast: Thomas Jefferson, the First Marines, and the Secret Mission of 1805 (New York: Hyperion, 2005).

16. For a celebration of "migration jihad," see Murtadda Mutahhari, Immigration and Jihad (London: Dar Al-Hadi Publications, 2003). For a much less favorable view, see Ann Corcoran, Refugee Resettlement and the Hijra to America (Washington, DC: Center for Security Policy, 2015).

17. For a discussion of whether China is a state that happens to own a civilization or "a civ- 
ilization pretending to be a state," see Lucian W. Pye, "China: Erratic State, Frustrated Society," Foreign Affairs 69, no. 4 (Fall 1990): 58.

18. For a sophisticated discussion of the relationship between different approaches to command and the situations in which forces find themselves, see Martin Samuels, Piercing the Fog of War: The Theory and Practice of Command in the British and German Armies, 1918-1940 (Warwick, UK: Helion, 2019), 1-47. 


\title{
The American Polar Pivot Gaining a Comparative Advantage in Great Power Competition
}

\author{
Ryan Burke, PhD; and \\ Major Jahara Matisek, U.S. Air Force, PhD
}

\begin{abstract}
This article demonstrates the rationale for the U.S. military to pivot its concentration toward defending the global commons in the polar regions of the Arctic and Antarctic. By defining the geopolitical significance of the polar regions, this article identifies actions the United States must take to strengthen current alliances and create new ones, while emphasizing investments in robust military assets to operate in the harsh polar environment conditions with extremely cold and long winters. This article concludes with recommendations on how U.S. military forces and basing should be integrated into a grand strategy to ensure that China and Russia cannot exert their control and influence over the polar regions of the Arctic and Antarctic.
\end{abstract}

Keywords: great power competition, polar warfare, Arctic alliances, Antarctic alliances, cold-weather military operations, Marine expeditionary units (MEUs)

I

$\mathrm{n}$ the frigid Arctic waters off the coast of Norway, Russian-trained whales are harassing local fishing boats. The Russians have reinvigorated their Cold War-era marine mammal training program as a part of their broader shift

Dr. Ryan Burke is an associate professor in the Department of Military and Strategic Studies at the U.S. Air Force Academy and a nonresident fellow with the Modern War Institute at West Point. He previously served as a Marine Corps officer and as a private consultant to the DOD in the Pentagon and with the Marine Corps Combat Development Command. Maj Jahara Matisek, $\mathrm{PhD}$, is an assistant professor in the Department of Military and Strategic Studies at the U.S. Air Force Academy and a nonresident fellow with the Modern War Institute at West Point. Maj Matisek is a mobility pilot with more than 3,000 hours of flight time and will be deploying to Afghanistan to fly the E-11 Battlefield Airborne Communications Node or BACN. 
toward polar region emphasis. ${ }^{1}$ The Chinese, not to be outdone, have built their first nuclear-powered icebreaker, deployed a squadron of polar-capable aircraft, and have sent an armada of fishing boats to Antarctica to exploit vast untapped and unprotected biological resources (e.g., fish, krill, etc.). ${ }^{2}$ Meanwhile, the United States remains distracted by combat operations throughout the Middle East and Africa. In addition, the United States is attempting a strategic rebalance back to the Asia-Pacific region as a result of Chinese expansionism, coupled with North Korean aggression. With this, the Indo-Pacific Command (INDOPACOM) area of responsibility (AOR) logically follows as the next great power struggle taking shape. Similarly, hostile behavior by Russia throughout the European AOR has forced the United States to redeploy forces back to the region.

With current strategic rebalancing focused on countering great power adversaries such as China and Russia, the United States has-mistakenly-emphasized the specific geographic regions near these nations as the renewed focus of military operations. In doing so, the United States continues to overlook Russian and Chinese actions in other regions of influence, missing strategic opportunities to influence and control the Antarctic and Arctic regions; this could be a potentially devastating strategic error decades in the making. An American pivot to these regions is needed. This pivot includes a militarization of assets and capabilities (and alliances) intended to contain, constrict, compete, and contest the evolving Russian and Chinese expansion, which threatens global commerce. The Arctic and Antarctica are the most overlooked arenas of twenty-first century great power competition.

Actions by China and Russia present emerging strategic problems to how the United States balances its military force structure in each AOR. This new era of near-peer competition in two different AORs compels the Department of Defense (DOD) to make the Global War on Terrorism (GWOT) a tertiary concern in an attempt to have the necessary military personnel to counter aggressive postures by China and Russia. As indicated in the Donald J. Trump administration's National Security Strategy (NSS), "China and Russia want to shape a world antithetical to U.S. values and interests" in an attempt to "challenge American power, influence, and interests ... to erode American security and prosperity." 3 Moreover, before retiring, Secretary of Defense James N. Mattis explicitly identified China and Russia as "revisionist powers" that are trying "to create a world consistent with their authoritarian models." ${ }^{4}$ Flowing from such logic, the 2018 National Defense Strategy (NDS) views China and Russia as strategic competitors requiring a renewed American military focus on lethality, strengthened alliances (and making new partners), and reforming the DOD for the right balance of performance and affordability. ${ }^{5}$ Despite such intense focus on China and Russia, it is superficially bent on their respective regions. Current 
American strategic visions overlook what China and Russia are doing outside of American defined AORs: the regions of the Arctic and Antarctica. Such a strategic omission is highly salient; neither region is explicitly identified as an area needing focus in the NSS or NDS. ${ }^{6}$ Even more telling, while the Russians continue their military buildup in the Arctic, as of April 2019, the post of the special U.S. representative for the Arctic is vacant in the Trump administration. ${ }^{7}$

Numerous European and Asian counties share similar diplomatic, military, and economic interests and seek enhanced security partnerships with the United States. The Indo-Pacific rebalance-as it is referred-intends to "strengthen, enhance, and broaden alliances" in this vital AOR. ${ }^{8}$ Relevant as it may be, though, we contend that Asia and Europe are not the most pressing concerns for U.S. global security interests today. Whereas the United States has established diplomatic, military, and economic interests and infrastructure throughout Europe and Asia from which it can exert influence, the Arctic and Antarctic regions (specifically the Arctic Circle) remain conspicuously bare in terms of equivalent infrastructure-or even demonstrated U.S. interest relative to other regions. This is a strategic failure that, absent increased military focus, will keep the United States woefully behind China and Russia in these regions. These near-peer states seek influence and control in this vibrant geographic region due to resources and new shipping lanes. While the United States and its allies have invested somewhat into each region, they must explicitly demonstrate resolve to control maritime trade routes, guarantee freedom of navigation, respect the rule of law, and commit hard and soft power approaches in the protection of them against revisionist states, such as Russia and China. In short, the United States needs to strategically rebalance toward the polar regions. The American polar pivot is needed for the maintenance of American hegemony in the twentyfirst century and beyond. Such logic falls in line with American antecedents of guarding global maritime commons, which have supported American trade and economic liberalism in global affairs.

This article serves as a call for American action to execute the polar pivot: reorienting U.S. military power and strategy toward the polar regions. It echoes the sentiment of the first American strategic thinking on this topic, Navy Rear Admiral R. H. Cruzen, who identified the necessity of military leaders needing to make "thoughtful consideration of the problems of polar warfare" in a 1948 lecture to the U.S. Navy War College. ${ }^{10}$ Given the rise of bellicose activities by China and Russia, a new form of great power competition is rapidly emerging in the Northern and Southern Poles. The United States and its allies lag behind in terms of policy, coordination, and military capability, as Russia and China began their own form of a polar pivot and military buildup in 2007 and 2017, respectively. ${ }^{11}$

There are tremendous resources present in each polar region; China and 
Russia have displayed substantial intent to exploit them. ${ }^{12}$ Moreover, as the Arctic Circle is expected to see further reductions in ice pack, this will expand existing shipping lanes—notably the Northeast Passage (NEP) and its western twin, the Northwest Passage (NWP) — potentially creating widely viable direct routes, such as the Transpolar Sea Route (TSR) bisecting the center of the Arctic Circle. China and Russia seem poised to control the NEP and NWP, which would be a significant challenge to American control of sea lanes and the global commons. Antarctica faces a similar accelerated melt off of marine ice that will open up new areas for resource extraction, which were once too expensive to access and exploit. ${ }^{13}$

A new gold rush is on for the "Cold Gold" polar resources that will shape and influence the twenty-first century of great power competition. ${ }^{14}$ This article contends that this new polar threat environment requires a robust military buildup by the United States and its allies to properly counteract hostile actions by China and Russia. Finally, this article concludes with recommendations on how Marine expeditionary units (MEUs) and other rotational force deployments should be redistributed and where new alliances might be forged to give the United States a competitive advantage in the polar regions to ensure American hegemony through the protection of global commons.

\section{Geography Matters: The Poles versus Everything Else}

In March 2019, the DOD Joint Staff solicited expert analysis from a targeted group of academics and practitioners seeking answers to the most pressing military questions of the so-called twenty-first century great power competition. ${ }^{15}$ One such question that flows from the NSS and NDS is particularly important: How can the United States best prepare itself for an evolving global conflict with the likes of China and/or Russia? Another question posed by the Joint Staff inquired about the character of global conflict and competition during the next 10 years. In answering these questions, we posit that the future of strategically significant great power competition will not happen in the South China Sea or Eastern Europe as so many prominent scholars predict, but rather it will be a fight over the spoils in the polar regions. ${ }^{16}$

Moreover, while the United States continues to emphasize twenty-first century technological innovations and weapons development over building alliances and expanded burden sharing, Russia and China are well ahead of the United States in securing their stake in the Arctic's vast energy resources and vital commerce lanes. Already, China has inked a deal with Russia for its so-called Polar Silk Road, while Russia is maneuvering and rebalancing itself to reach the estimated U.S. \$35 trillion worth of untapped oil and natural gas - not to mention other unknown amounts of precious minerals - in the thawing Arctic. ${ }^{17}$ Each nation is taking numerous steps to attain a robust position of power 
in the Arctic and Antarctic as a means of counterbalancing American primacy elsewhere. The twenty-first century great power competition will not be won by technology alone; it will instead be won by those nations possessing the right balance of modern platforms, basing infrastructure from which to station troops and employ weapon systems and maintaining strong alliances.

One of the leading challenges in the way of realizing the necessity of the polar pivot is the continued and vocal advocacy of weapons modernization. If these great power competition questions were presented to defense hawks, some answers would no doubt emphasize the so-called Revolution in Military Affairs (RMA) concept. RMA implies that evolving technology will change the nature and character of warfare, and that those military powers possessing the most advanced technology will prevail in future military conflicts of the twenty-first century. ${ }^{18}$ While possession of superior technology almost certainly provides advanced military capability, superior technology alone does not win wars. The American efforts in Vietnam, Iraq, and Afghanistan to date are archetypical examples of such technology-driven efforts where superior military force enabled by superior technology was insufficient to combat insurgents and terrorists intent on resisting American occupation and Western influence. This is not to say that technology is irrelevant or that it will not aid in military victory. It is to say, rather, that reliance on superior technology alone-and the resulting perception of competitive military advantage stemming from such superior technology - is ill-founded and, frankly, ignorant.

The technology trend that so many defense advocates stand behind in search of the next silver bullet in weapon system technology development is not the only fad that will drive future change in global competition and conflict. Those lacking superior technology tend to be more adaptable and creative; even the most technologically advanced militaries in the world find themselves, at times, vulnerable to relatively primitive-yet successful — attacks. To utilize modern technology, militaries require, at the very least, bases and infrastructure from which to employ it. The nature and character of future conflict will be influenced equally by geography and technology. Global expansionism via military infrastructure, while discredited as unnecessary by strategy of restraint advocates, enables continued influence in strategically vital areas of geographic interest. ${ }^{19}$ In this way, military powers with the greatest global influence, regardless of their technology, will be most likely to shape global competition and the resulting conflict far into the twenty-first century.

The Chinese effort to expand territorial claims in the South China Sea and East China Sea are ongoing. ${ }^{20}$ With control_or at least geographic influence-of such critical waters to the global economy, Chinese land and power grab efforts in these areas should come as no surprise to those familiar with the international security landscape. For the Chinese, as with the Russians, the 
Arctic may be the next region in their sights for continued global economic influence.

Anthropogenic climate changes have objectively altered polar landscapes in the twenty-first century, making these regions some of the most strategically important areas on the planet for both influence and control. ${ }^{21}$ In particular, the Arctic Circle provides a direct avenue of approach for military powers with the capability to exploit dwindling sea ice obstructions and to traverse what was once considered an impassable region of the world. Melting sea ice combined with improving icebreaker capabilities allows some polar capable countries (i.e., those with access and technological abilities) progressively greater access to more of the Arctic Circle. This is one area, however, where Russia has the comparative technological and numerical advantage for tactical polar operations.

The most capable U.S. heavy polar icebreaker-the USCG Polar Star (WAGB 10) - is capable of navigating ice up to six feet thick at continuous speeds of three knots. ${ }^{22}$ This U.S. icebreaker can navigate $159,426 \mathrm{~km}^{2}$ of the $271,304 \mathrm{~km}^{2}$ winter time ice totals in the Arctic, or approximately 59 percent of the winter ice coverage. The United States has one such heavy operational icebreaker in its inventory. Russian icebreakers, in contrast, are capable of navigating ice up to 13 feet thick; more than double that of the most advanced U.S. icebreaker. ${ }^{23}$ Russia maintains more than 40 icebreakers and has another 11 under production. ${ }^{24}$ This capability gives Russia access to $269,958 \mathrm{~km}^{2}$ of Arctic winter ice, or 99 percent, far surpassing current U.S. accessibility. With 99 percent of winter ice coverage available, Russia enjoys exclusive access to the NWP and NEP, each with potential oil and gas reserves. Not to be left out, China built a nuclear-powered icebreaker in 2018 and created an Antarctic flying squadron to support operations at the South Pole. ${ }^{25}$ American capabilities to project power in the polar regions are severely lacking. With only one operational icebreaker, current budgetary plans are in place to acquire six operational icebreakers by 2023 — assuming defense budget hawks will permit this polar pivot. $^{26}$

The direct approach via the TSR (and other potential yet unrealized routes) is one of many such motivations for Arctic expansion. More importantly, controlling territory in the Arctic may yield tremendous economic benefits via oil and liquid natural gas extraction and the possible presence of other valuable minerals. ${ }^{27}$ With 15-20 percent of its gross domestic product (GDP) reliant on Arctic resources, Russian claims to this region are both an economic and military imperative. ${ }^{28}$ In addition to Russian interests in the region, China expressed interest in the poles via a white paper policy document released by their State Council Information Office. It emphasized protection of the environment, pursuit of scientific research, and support of multinational governance in the region. ${ }^{29}$ Since 1980 , the Arctic Sea ice coverage has steadily 
declined at a rate of 12.8 percent per decade. ${ }^{30}$ This steady decline in sea ice and expanding navigable waters underscores the developing opportunity for ambitious nations.

Russian interest in the Arctic Circle is multifaceted, given the country's northern border is immediately adjacent to the Arctic Circle. With Russia's apparent interest, or at least signaling, in reunifying territories of the old Soviet Union, a northern flanking approach via expanded military presence in the Arctic Circle may enable surrounding regional influence on the Scandinavian nations first and the Baltic states by extension. This is entirely possible given that, besides geographic advantage, Russia maintains a robust number of military assets in the Arctic Circle, with clear intentions to increase this presence. A 2015 report showed that Russia stationed 19 icebreakers and 34 submarines in the Arctic, paling in comparison to one American icebreaker and no submarines. ${ }^{31}$ From a 2018 estimate on the Russian military presence in the Arctic, there were six Russian bases, each equipped with the highly effective long-range S-400 Triumph air defense systems, and 40 icebreakers. ${ }^{32}$ More worrisome is that the Canadian Press reports that Russia is developing 11 additional icebreakers, and it has deployed more resources and created new infrastructure in the Arctic, including 4 new Russian brigade combat teams, 14 new operational airfields, and 16 deepwater ports. ${ }^{33}$

Complicating matters is the lack of law governing international waterways. Currently, the United Nations Convention on the Law of the Sea (UNCLOS) is the only document governing maritime conduct in international waters. Russia twice petitioned UNCLOS - in 2001 and again in 2015-to grant them extended territorial waters in the Arctic. ${ }^{34}$ UNCLOS has yet to grant such an extension, but this is a strong indication of continued Russian interest in establishing an enforceable territorial boundary in the Arctic. The problem with UNCLOS is that it is not an authoritative treaty, and there are few enforceable deterrents that could dissuade Russia or China from complying with UNCLOS parameters if their procedural requests are denied. In other words, the Arctic is ripe for military expansion. With a lack of American emphasis on the polar regions and with no robust military presence or capability to operate there, this emerging problem requires a drastic reorientation of U.S. strategic priorities and capabilities to confront the emerging Russo-Sino polar alliance.

\section{The Polar Pivot-Defined}

With the polar environments in the Arctic and Antarctica changing, the United States must prepare to defend these protected regions from any nation that may exploit them in violation of international law (e.g., Exclusive Economic Zones [EEZs], etc.). Crucial shipping lanes (e.g., NEP, NWP, Africa's Cape of Good Hope, etc.) and an abundance of natural resources make the polar regions in- 
creasingly valuable, especially as oceanic temperatures melt sea ice and glaciers. The rising geopolitical importance of the polar regions must be considered (and mentioned) in the U.S. 2018 National Military Strategy (NMS) and in future iterations of the NSS and NDS. The DOD's 2019 Arctic Strategy identifies the Arctic as an "avenue for expanded great power competition and aggression." ${ }^{35}$ While an updated Arctic strategy is a welcomed effort, this should be reoriented or updated to include a comprehensive polar strategy that includes the Antarctic region that, while not geographically close to America, has similar geopolitical ramifications. This is indicated by China's similar distance from Antarctica, but its willingness to invest resources and operate in Antarctica. ${ }^{36}$

Russia continues to push the boundaries of what is deemed acceptable, especially against the Arctic Circle neighbors of Canada, Greenland (an autonomous territory of Denmark), Iceland, Norway, Sweden, and Finland. Around the Antarctic Circle, China poses the greatest threat to South Africa, Australia, New Zealand, Chile, and Argentina. NATO members, Norway especially, are concerned that Russian military activities are creating an "anti-access/area denial 'bubble' that would cover a significant portion of their territory and prevent NATO from coming to its defense." ${ }^{37}$ Similarly, Australia has demonstrated substantial apprehension regarding China's numerous activities and new scientific bases in Antarctica that blur lines of legality in the region. ${ }^{38}$ The Arctic is a coastal body, presenting potential great power competition at the border of the U.S. homeland, and it is therefore understandable that the United States should adopt a formal Arctic strategy. However, these challenges are not reserved to the Arctic alone but rather to the polar regions as a whole. The United States needs to acknowledge a true polar emphasis in these new strategies rather than one that solely focuses on the geographic proximity of the Arctic.

As environmental factors make the polar regions easier to traverse, Russia will continue actions that undermine the rules of the sea as well as other laws regarding EEZs and international waters. Similarly, while China is far from each polar region, 2018 was the first time China had introduced a white paper policy on this issue. This official government document highlighted the importance of melting ice caps facilitating a so-called Polar Silk Road for trade and various ways in which China might economically benefit from resources in each region. ${ }^{39}$ While "fully ice-free summers probably remain a decade or more away," this gives America (and its allies) time to prepare. ${ }^{40}$ This means developing hard power capabilities, such as improved icebreaker ships, creating/training specialized polar-capable troops, and military weapon systems to operate in such harsh climates. Additionally, it will require improving soft power capabilities, such as strengthening alliances and information/media discourses against China and Russia, all while creating legal frameworks so as to avoid the tragedy of the commons dilemma, in which individual nations act in their own self-interest rather 
than for the good of the world as a whole. These courses of action will likely deter illegal and antagonistic actions in the region, while ensuring economic prosperity for those abiding by all laws and norms in each polar region.

Nevertheless, the potential for a hot war over the Arctic (and to a certain extent, the Antarctic) remains. ${ }^{41}$ A U.S. government estimate notes the Arctic region could have about 90 billion barrels of oil, 1,700 trillion cubic feet of natural gas, and 44 billion barrels of liquid natural gas. ${ }^{42}$ The abundant (and untapped) natural resources of the polar regions may incentivize states to begin making territorial claims, including creating new military bases and conducting military exercises as a way of demonstrating control of contested areas, much as Russia has already been doing. ${ }^{43}$ The decrease in ice coverage also opens up new and more efficient maritime routes.

Aggressive and antagonistic actions by China in the South China Sea demonstrate their resolve to control and exploit maritime routes; China will likely act in a similar manner in each polar region, especially with reports that they are investing in military capabilities to operate in each pole. ${ }^{44}$ Because of these threats to free trade, which is a vital U.S. national interest, the United States must engage its national instruments of power vis-à-vis a polar pivot to assert the need for a rules-based authority in each polar region. However, such a grand strategy for the polar regions requires more than words and policy documents; concrete actions are required by the United States and its allies in each region to demonstrate a robust resolve to counter adversarial actions by China and Russia. Whereas the multinational Arctic interest is complicated by environmental as well as geographic factors, the Antarctic region presents a distinctly different series of considerations informing any future polar strategy.

Antarctica hosts three year-round American research stations: McMurdo Station (on Ross Island), Amundsen-Scott South Pole Station (at the geographic South Pole), and Palmer Station (on Anvers Island). These U.S.-funded stations fall under the National Science Foundation (NSF) and serve as multinational research centers with an array of scientists from all over the world. ${ }^{45}$ This is the only established U.S. government infrastructure and there is no form of militarization anywhere on this continent. Besides the American presence, 32 countries maintain about 50 research bases. ${ }^{46}$ Finally, Antarctica serves an indirect military purpose, as many countries have built satellite relays for the purposes of improving navigation precision and secure communications.

The first article of the Antarctic Treaty System (ATS) outlines that military assets are to only be used in Antarctica to assist with scientific research, logistics, and search-and-rescue missions. ${ }^{47}$ While this treaty does not extend to the Arctic, members of the Arctic Council are attempting to define their territorial boundaries according to the ATS and UNCLOS. ${ }^{48}$ Just as territorial boundar- 
ies and treaties can be set, they can also be infringed upon. Already, Chinese involvement in Antarctica is a blurred, gray line between research and military operations, as China builds Antarctic airstrips and modifies/upgrades military aircraft for polar operations. ${ }^{49}$ Continued Chinese militarization in Antarctica cannot be disregarded by the United States as insignificant. The Chinese are intent on globalizing their military influence; Antarctica is no exception. The United States must recognize this reality and consider its commitment to the ATS relative to its strategic priorities. While Antarctica may not rival the Arctic in terms of geographic relevance or economic importance to the United States in terms of great power competition, it is an area of likely exploitation and of great strategic importance to an American rules-based order. The United States should revisit the terms of the ATS and give due consideration to whether continued commitment is warranted given Chinese actions on the continent to develop infrastructure and extract resources.

Military conflict (and/or competition) in the polar regions could significantly impair critical research, impact seafaring trade, and through exploitation, lead to the degradation of both environments. ${ }^{50}$ Any actions-intentional or unintentional_-in each polar region might accelerate current ice cap melt trends, contributing to rising sea levels that submerge and destroy coastal cities, including putting at least 128 U.S. military bases around the world at risk. ${ }^{51}$ Without a doubt, each polar region is a vital national interest of the United States, requiring an active and direct intervention by American political and military leaders. The DOD 2014 Climate Change Adaptation Roadmap reaffirms the rationale of involvement — and the dire risks associated with failing to address the challenges emerging in each polar region. ${ }^{52}$ American and allied direct action in each region is a necessary precondition given the unresolved issues of sovereignty in the Arctic and Antarctic.

\section{The Polar Pivot-Executed}

A necessary precondition for maintenance of American hegemony is to realize that the gains of the proposed polar pivot requires control—or at least influence-over the polar regions. Such reasoning appears to influence the how and why of Chinese and Russian thinking in their attempts to supplant the United States as the hegemon-in the polar regions, at least-justifying their large investments in military assets and infrastructure in each polar region.

Unfortunately, there is too much U.S. emphasis on competing in Asia and Eastern Europe. American deterrence efforts in the South and East China Seas have been largely ineffective to date; China continues expanding its artificial island construction, with the total reclaimed area exceeding 3,200 acres. ${ }^{53}$ American rhetoric has only amounted to veiled threats and toothless policy statements that lack budgeted intent. These statements are irrelevant and ineffective, re- 
gardless of focus, as there have been numerous occasions in which Congress has budgeted for polar capabilities but funds are reallocated for a different priority, such as the border wall along Mexico. ${ }^{54}$ The Arctic situation is a potential multipeer adversarial environment with geographic proximity more concerning to the United States than the situation in the South and East China Seas. To the south, Antarctica is also a multipeer environment with many powers claiming to have discovered the continent-or least expressing imagined claims to its resources. ${ }^{55}$ Both China and Russia seek influence in the polar regions and are decades ahead of the United States in securing their place as regional influencers given their level of polar military capabilities (and provisions to further increase their numerical advantage). This should concern the United States and its allies, compelling real action, as climate change will make it increasingly difficult for America and its allies to respond to polar threats if capabilities do not exist to respond and deter. ${ }^{56}$

If we accept the logic that Chinese actions in the South and East China Seas is a transit of the commons issue and a violation of international law and EEZs, the Arctic is exponentially more important in terms of the global commons because of the plentiful resources and the potential trade routes established by continually melting sea ice. Further, if we operate from the assumption that executing the proposed polar pivot is difficult because the United States is the defender of the commons, then we must extend the same logic to respond to bellicose Chinese obfuscation in the South and East China Seas. The United States continues to define itself as a defender of the global commons and freedom of navigation, supported most recently by expanded military involvement in the INDOPACOM AOR. But the defender of the commons title should not be limited to convenience; rather, should the United States desire to maintain such status and act in its accordance, it must also emphasize the greater threat to global trade in both polar regions. The real question is: Does this polar problem warrant attention and action, and can anything be done about it?

\section{Rebalancing Military Forces for the Polar Regions: Send in the Marines?}

Currently, the American prepositioned global military presence far exceeds that of any other nation. However, despite U.S. force postures influencing diplomatic, military, and economic efforts in a myriad of global hot spots, America sorely lacks geographic influence in the polar regions. Specifically, U.S. military force posture and infrastructure are nearly nonexistent in these regions. For instance, Marine Corps Forces, Pacific, maintains the Marine Rotational Force-Darwin program, deploying about 1,500 Marines on six-month continuous rotations to Darwin, Australia. ${ }^{57}$ While firmly entrenched in the Southern Hemisphere, this rotational force presence is situated on the extreme north central coast of 
Australia, still thousands of miles north of the Antarctic continent, making it rather difficult to influence Antarctic matters from this distance.

Thousands of miles away, smaller contingents of Marines have in recent years participated in European theater training exercises in Poland, Norway, and the Baltic states as part of Exercise Baltic Operations (BALTOPS) and Exercise Saber Strike. ${ }^{5}$ Such rotational force deployment programs should not be limited to these few areas of keen geopolitical U.S. interest. Rotational force programs as the Marines employ them necessitate consideration as a means of executing the proposed polar pivot. Deploying Marines, at the least, to the poles via rotational forces sends a clear message of U.S. commitment to the security and stability of the polar regions to great power adversaries. Additionally, deploying temporary rotational forces such as those in Australia and northern Europe to the polar regions provides the United States a visible yet resourceefficient military power projection platform requiring minimal logistical and infrastructure support relative to more traditional and resource intensive deployment options.

Marine rotational forces, in particular, enjoy the flexibility of seabasing options, in addition to forward operating base locations. A Marine rotational force deployed to either pole may not require established land-based infrastructure to be an effective operational force, provided the availability of alternative amphibious ship platforms to serve as expeditionary seabases patrolling navigable international waters. Weather, high seas, seasonal darkness, and ice coverage may render seabasing via naval vessels impossible in and around the polar regions much of the year, but such rotational deployments remain an option for targeted periods of more tenable conditions and locations in or near the poles. Beyond seabasing in the polar regions, the United States should consider Marine rotational force deployments within the Arctic Circle in northern Alaska to signal American resolve to Russia.

Alaska's territory in the Arctic Circle makes for less than hospitable environments for most military Services requiring the traditional niceties of modern society. However, the Marine Corps' ability — and willingness — to operate independently in "any clime and place" makes it the ideal force for rotational land-based deployments to unpopular but strategically imperative global regions such as the poles. Small inhabited areas on the northern Alaskan coast offer airstrips and minimal grid infrastructure to potentially support rotational military forces in the vicinity. In 2015, the U.S. Coast Guard established temporary forward operating locations near Prudhoe Bay (Deadhorse) and Barrow, Alaska. ${ }^{59}$ These locations can serve as potential locations for temporary Marine rotational forces, provided there is local, state, tribal, and federal government coordination. Failing to establish a forward, sustainable presence in this way leaves the United States further behind the Russians while they employ a similar approach 
on their northern Arctic-facing borders and islands. ${ }^{60}$ Many Russian bases have advanced missile defense systems and surface-to-air missile capabilities.

While Marine rotational forces actively deploy to Australia and/or northern Europe as part of training and readiness efforts, MEUs deploy rotationally around the world and are far more expeditionary than their Darwinian-, Baltic-, and Scandinavian-deployed rotational counterparts. Given the new Arctic strategy's call for an "Arctic deterrent" requiring "expeditionary forces," the MEU deployment option provides yet another potential power-projection option for the United States to consider as it executes the proposed polar pivot. ${ }^{61}$ Of the seven standing MEUs, three are based on the West Coast of the United States; three on the East Coast; and one in Okinawa, Japan. Two or three MEUs — one each from the East and West Coasts, and potentially the Okinawa-based MEU, depending on rotational cycles - are forward deployed at all times, while the remaining MEUs conduct predeployment training workups or reset in dwell from previous deployments. ${ }^{62}$ MEUs possess the multidomain power projection capabilities of a Marine Air-Ground Task Force (MAGTF), complete with an aviation combat element, ground combat element, logistics combat element, and command element. These tailorable, scalable, and expeditionary force packages are uniquely suited to influence military operations from ship to shore in expeditionary and logistically limited environments in the polar regions.

MEU deployments typically follow predictable deployment patterns and trajectories emphasizing threats in Central Command (CENTCOM), Africa Command (AFRICOM), and INDOPACOM. If the polar regions present insurmountable budget and logistics difficulties in establishing static basing infrastructure to assert influence and control, the MEU-centric seabase provides a viable alternative in executing the proposed polar pivot and projecting multidomain combat capability in areas that China and Russia have otherwise enjoyed uncontested access to. Deploying Marines to these inhospitable locations will produce valuable domain awareness and a sustained, albeit rotational, military presence in the polar regions much needed in the evolving landscape. This is not to say that MEUs can access the polar waters without limitation. Rather, redirecting and reorienting established MEU deployments in the vicinity of the polar regions may be required in an effort to compete with, contest, and contain the ongoing Russian and Chinese polar expansion efforts.

Such considerations of alternative MEU deployment areas, provided sufficient capability and seasonal conditions to enter or approach polar waters, is a necessary indication of U.S. interest in securing the polar regions. The United States should continue in this vein, reorienting carrier strike group (CSG) and other surface ship package deployments to the polar regions, much like the deployment of the USS Harry S. Truman (CVN 75) Strike Group 8 into the Arctic Circle in October 2018. ${ }^{63}$ There is some discussion on this front as of late 
2018 under then-Secretary Mattis's “dynamic force employment” concept. Discussions about avoiding unpredictability while integrating newly determined strategic locations are vital to continued global competition. ${ }^{64}$ In this way, the United States should consider reorienting amphibious ready groups, MEU, and CSG deployments to include unannounced rotations through the accessible polar regions. A show of force in this context will augment the ongoing U.S. military exercises in the Arctic, such as ICEX and Arctic Edge. Deploying additional forces committed to training in these harsh conditions may also send a strong message of U.S. commitment to securing the polar regions. Such a message would be significant to influence further action from current and future U.S. allies committed to gaining and maintaining a comparative advantage over China and Russia but require U.S. logistics and support to do so. Moreover, it would provide the experience of operating in a polar environment, which would benefit American military forces in a future deployment to the region.

Finally, some strategic airlift capability exists near Antarctica, as the U.S. Air Force maintains a seasonal summer contingent of Boeing C-17 Globemaster IIIs and Lockheed C-130 Hercules in Christchurch, New Zealand, to resupply McMurdo Station. ${ }^{65}$ In the Arctic, the nearest American military installation is at Thule Air Base, Greenland, but there are no assigned aircraft, as its primary mission is to support the "global network of sensors providing missile warning, space surveillance and space control." ${ }^{66}$ The next closest American base to the Arctic is Eielson Air Force Base, Alaska. Located in central Alaska near Fairbanks, and about 1,700 miles away from the North Pole, it is hardly close enough to intimidate Russia. ${ }^{67}$ Commitments of such visible military force posture via air, land, and maritime domains to strategically vital regions of the world would speak volumes to Russian and Chinese expansionism in the poles. Increased U.S. presence and orientation toward the polar regions is not without potential risk. Such reoriented efforts may lead to currently uncontested and noncompetitive regions evolving into competitive and eventually contested regions. This, in turn, could well lead to a miscalculation, escalation, and eventually confrontation. The United States must account for these possibilities in developing a future polar strategy that increases force posture in the regions. But simply expanding and increasing force postures in the poles is, by itself, insufficient to realize the full effects of the polar pivot. The United States must also consider, as it has elsewhere, the potential benefits of improved alliances and burden sharing for nations with similar interests in the security and navigability of international polar waters for geopolitical reasons.

\section{Polar Military Partners: Alliances and Burden Sharing}

Simply put, the American polar pivot cannot become reality absent the support and engagement of other polar-invested nations. The current political and 
defense budgetary climates are such that the poles are an afterthought in policy making. Despite the U.S. status as a nation that borders the Arctic, Arctic force posturing is relegated in favor of near-term threats instead of long-term strategic problems. Arctic emphasis ebbs and flows; it rises and falls with the changing of administrations. ${ }^{68}$ This is ironic given the billions of dollars spent on foreign military assistance efforts that are thousands of miles removed from U.S. territories. ${ }^{69}$ Meanwhile, Russia currently has missile sites in the Arctic capable of reaching the U.S. homeland, naval vessels that can navigate via Arctic routes uncontested right up to American coastlines, and an electronic warfare system that covers the entirety of the Arctic Circle. ${ }^{70}$ Further complicating matters is the current bifurcation of polar command responsibilities.

The Arctic, for instance, transcends the AORs of U.S. Northern Command (NORTHCOM), European Command (EUCOM), and INDOPACOM. Given its outward orientation toward the homeland defense mission, NORTHCOM advocates for and understands the importance of the Arctic as a militarily relevant region. Other geographic commands focus on the problems within their AORs rather than those emanating from beyond their borders. As such, whether the other commands are (or should be) equally concerned about the Arctic is a matter of debate among defense policy circles.

Antarctica falls within the AORs of the U.S. Southern Command (SOUTHCOM), AFRICOM, and INDOPACOM, and is equally on the periphery of each command's focus. Beyond these concerns, polar orientation must contend with the unique bureaucratic hurdles specific to each region. Indigenous populations in Canada must be consulted during military exercises in their areas and prior to the construction of any basing infrastructure (temporary or permanent). The ATS restricts military operations except for research and safety support functions. And finally, the logistics of polar operations is extraordinarily complex. Everything slows in the cold; construction of infrastructure takes longer and costs more in these harsh and seasonally limiting conditions, particularly when dealing with construction on tundra. Between bifurcated command lines and budgetary, bureaucratic, environmental, and logistic limitations, one can understand why the United States does not have a robust polar strategy in place, but it should nonetheless. For the reasons mentioned, the United States cannot succeed alone in the proposed polar pivot. Such a strategy requires strong alliances and diffused burden-sharing arrangements with other polar-interested nations to be effective.

\section{American Polar Alliances against China and Russia?}

American alliances with polar-interested nations need to expand to ensure continued force posture and future influence in these soon-to-be contested regions. Focusing on alliance building and maintenance first will enable resource 
deployment and diffused burden sharing in the future rather than a mostly U.S.-supported military posture. Given the difficulty of shifting resources toward polar capabilities, American alliances would help partner nations execute a similar polar pivot. Convincing polar allies to shift resources toward polar military capabilities under the guise of newfound or renewed security cooperation with the country would allow the United States to maintain its conventional military edge, while partner militaries would provide a comparable advantage in polar military operations. We have already seen examples of such alliance efforts countering China in the Arctic, with the Pentagon convincing Denmark to fund infrastructure (e.g., airports) in Greenland to prevent Chinese investment and basing there. ${ }^{71}$

With a firmer security cooperation agreement in place, there will presumably be more diffused burden sharing as more nations will determine vital interests in the polar regions and seek to contribute to the situation to ensure their own interests are supported by a growing coalition of cooperative nations. A coalition of such measures will generate the perception of a competitive advantage for participating nations that cannot otherwise compete with the likes of Russia and China in the polar regions and in other domains. With the help of the United States, near-polar states can rise to a formidable level in the era of twenty-first century great power competition.

Building, fostering, and maintaining polar-based alliances is a necessity for future U.S. interests in the Northern and Southern Hemispheres. American adversaries show interest and intent with substantial investment in these regions as China and Russia have extended this into military action. The United States needs to rebalance military and alliance capabilities toward countering the polar postures of Russia and China. Their current combined polar military capability vastly exceeds the United States, its allies, partners, and friendly nations (e.g., Chile, Finland, and South Africa) around the Arctic and Antarctic Circles.

Given Canada's proximity and close relations with the United States, the polar pivot could be actualized through U.S. support of base development and manning at Canadian Forces Station (CFS) Alert, Ellesmere Island, Nunavut, Canada. Given that CFS Alert is a weather and intelligence station, and as Canada's most northern military base, developing it into a robust military installation with barracks, airport, and a deepwater port would send another strong signal to China and Russia about U.S. intentions of countering the polar militarization efforts they are pursuing in the Arctic Circle. ${ }^{72}$ Moreover, it would serve Canada's strategic interests as well, given the vast amounts of resources trapped within the Canadian-Arctic EEZ. ${ }^{73}$

If Russia and China continue to expand their efforts and operate uncontested and unchecked in the polar region, they will soon dominate the region. This could include control of economic trade routes, imposition of passage tolls, and 
restricted access to (and control of) vital and profitable energy resources. One could even envision a scenario where Russia, in asserting uncontested military control, would extract tolls and impose permit requirements to operate in and transit the Arctic. While more difficult to impose such control in Antarctica, China has already demonstrated its desire to exploit fisheries to the maximum extent possible, causing major disruptions to Antarctic food chains. ${ }^{74}$ If Russia and China were to further militarize the Arctic and violate laws and norms there, the United States and allies would need to consider revoking the Svalbard Treaty, which prevents Norway from militarizing this archipelago that is about 600 miles away from the North Pole. ${ }^{75}$ Such an action would enable Norway and other NATO allies to build up a sizable military force and infrastructure on Svalbard, which hosts a population of about 3,000, as a means of deterring future hostilities from China and Russia. It would also require the expulsion of Chinese and Russian intelligence personnel that work on Svalbard, which is considered a critical node for communicating with their respective spy satellites. American efforts should also be pursued with Sweden and Finland, nonaligned countries that are participating in U.S.-NATO Arctic military exercises as "enhanced opportunities partners." 76

Newly expanded trade routes and strategic interest in the Arctic region will fundamentally change global trade and provide advantages to those who control it. This is a race for territorial control and expansion, garnering influence over global trade. Control of the Arctic produces gains for the controlling nationdiplomatic, military, information, and especially economic capital, potentially beyond the scope and capacity of any other region of interest. The polar regions are similar to the South China Sea dispute in that they are controllable to those committed to doing so. If the polar regions come under the control of hostile powers intent on winning the future great power competition, freedom of navigation in international waters will be challenged. Russia and China can and will asymmetrically challenge the United States in an area that will generate a strategic advantage they have sought for decades.

\section{Conclusion: Making the Polar Pivot Stick-Finally}

While some might believe such a polar pivot is overhyped and unnecessary, presidential administrations since Richard M. Nixon have directed the National Security Council to have an Arctic policy. ${ }^{77}$ Unfortunately, very little of this policy has been substantiated through military power to counteract Russia, and now recent Chinese activity, in their efforts to militarize the polar regions toward the objective end of exploiting natural resources and securing commercial shipping lanes. The United States needs a strategic rebalancing effort that extends beyond the current INDOPACOM AOR. As large and sustained com- 
bat operations are reduced in CENTCOM, the American government must consider its geographic presence in the contested polar regions. Reorienting rotational force efforts to expand operations at the poles will deter continued Russian and Chinese military expansion in these geographically critical regions of the world that, until now, few policy makers have truly emphasized as areas of global interest in the future of great power completion and conflict.

A failure to defend U.S. (and ally) interests in the Arctic and Antarctica will have lasting impacts on the environment, free trade, and global security. If the Western status quo remains, the question is not if disagreements over resources and territorial claims will spark conflict in the Arctic and Antarctica, but rather when and how. The polar regions are critical to scientific efforts to reduce the effects of climate change, which could change the face of the world's coastlines, causing irreparable economic damage, even submerging numerous strategically vital military bases and ports around the world..$^{78}$ Losing critical American and allied military infrastructure would greatly reduce U.S. global reach, weakening American military power projection in the twenty-first century.

It is imperative that the United States and allies prepare to defend (and deter) the exploitation of the poles from revisionist states attempting to expand their influence and power. With extreme climates at each pole, the American military must have the right equipment (e.g., icebreaker ships), training (e.g., cold weather military exercises), and strategy (i.e., American political willpower) to diplomatically and militarily fight for each region. Without such resolve, China and Russia will rapidly establish an advantage in each pole. If the West loses its foothold, there will be no leverage in negotiating settlements and treaties that are a win-win for all near-polar countries that seek a rules-based order. Returning to Admiral Cruzen's thoughts on polar operations in 1948: "strategic thinking and our military and naval training" cannot be "confined to the tropic and temperate zones." ${ }^{79}$

\section{Notes}

1. Hannah Ellis-Petersen, "Whale with Harness Could Be Russian Weapon, Say Norwegian Experts," Guardian, 29 April 2019.

2. Rob Curtin et al., Resources in Antarctica: With the World's Dwindling Natural Resources, Is There a Chance for Exploitation in Antarctica? (Christchurch, New Zealand: University of Canterbury, 2004).

3. Donald J. Trump, National Security Strategy of the United States of America (Washington, DC: White House, 2017), 1-2, hereafter NSS.

4. Idrees Ali, "U.S. Military Puts 'Great Power Competition' at Heart of Strategy: Mattis," Reuters, 19 January 2018.

5. James N. Mattis, Summary of the National Defense Strategy: Sharpening the American Military's Competitive Edge (Washington, DC: Department of Defense, 2018).

6. The Arctic is passively mentioned once: "A range of international institutions establishes the rules for how states, businesses, and individuals interact with each other, across land and sea, the Arctic, outer space, and the digital realm." Trump, NSS, 40. 
7. Vladimir Isachenkov, "Russia Revamps Arctic Military Base to Stake Claim on Region," Associated Press, 4 April 2019.

8. "DOD Focus on the Indo-Pacific," U.S. Department of Defense, January 2018, accessed 2 May 2019.

9. Tara Murphy, "Security Challenges in the 21st Century Global Commons," Yale Journal of International Affairs 5, no. 2 (Spring/Summer 2010): 28-43.

10. R. H. Cruzen, "Polar Operations," Naval War College Information Service for Officers 1, no. 4 (1949): 1-15.

11. Caitlyn L. Antrim, "The Next Geographical Pivot: The Russian Arctic in the TwentyFirst Century," Naval War College Review 63, no. 3 (Summer 2010): 15-38; Matthew Bodner, "Russia’s Polar Pivot," Defense News, 11 March 2015; Bryan Clark and Jesse Sloman, Securing the Frontier: Challenges and Solutions for U.S. Polar Maritime Operations (Washington, DC: Center for Strategic and Budgetary Assessments, 2017); and Jane Nakano, "China Launches the Polar Silk Road," Center for Strategic and International Studies, 2 February 2018.

12. Donald L. Gautier et al., "Circum-Arctic Resource Appraisal: Estimates of Undiscovered Oil and Gas North of the Arctic Circle," USGS Fact Sheet 2008-3049, U.S. Geological Survey (2008).

13. R. H. Levy et al., "Antarctic Ice-Sheet Sensitivity to Obliquity Forcing Enhanced through Ocean Connections," Nature Geoscience 12, no. 2 (2019): 132-37, https://doi .org/10.1038/s41561-018-0284-4.

14. Heather A. Conley et al., Arctic Economics in the 21st Century: The Benefits and Costs of Cold (Lanham, MD: Center for Strategic and International Studies, 2013).

15. Strategic Multilayer Assessment (SMA)—Future of Great Power Competition (GPC) \& Conflict, 24 January 2019.

16. For example, most prominent authors do not consider the polar regions in their analysis of great power competition. See John J. Mearsheimer, "The Gathering Storm: China's Challenge to US Power in Asia," Chinese Journal of International Politics 3, no. 4 (Winter 2010): 381-96, https://doi.org/10.1093/cjip/poq016; Dimitar Bechev, Rival Power: Russia in Southeast Europe (New Haven, CT: Yale University Press, 2017); and Thomas Wright, All Measures Short of War: The Contest for the 21st Century and the Future of American Power (New Haven, CT: Yale University Press, 2017).

17. Clay Dillow, "Russia and China Vie to Beat the U.S. in the Trillion-Dollar Race to Control the Arctic," CNBC, 6 February 2018.

18. Elinor C. Sloan, The Revolution in Military Affairs: Implications for Canada and NATO (Montreal, Canada: McGill-Queen's University Press, 2002).

19. Barry R. Posen, Restraint: A New Foundation for U.S. Grand Strategy (Ithaca, NY: Cornell University Press, 2014).

20. Megan Specia and Mikko Takkunen, "South China Sea Photos Suggest a Military Building Spree by Beijing," New York Times, 8 February 2018.

21. James Kraska, ed., Arctic Security in an Age of Climate Change (New York: Cambridge University Press, 2011).

22. Ronald O'Rourke, Coast Guard Polar Security Cutter (Polar Icebreaker) Program: Background and Issues for Congress (Washington, DC: Congressional Research Service, 2019).

23. Camila Domonoske, "Russia Launches World's Biggest, Most Powerful Icebreaker," NPR, 16 June 2016.

24. "Major Icebreakers of the World," United States Coast Guard, Office of Waterways and Ocean Policy, accessed 2 May 2019.

25. Michael Peck, "Why Is China Building a Nuclear-Powered Icebreaker?," The Buzz (blog), National Interest, 14 September 2018; and Shannon Tiezzi, "China to Establish Antarctic Air Squadron in 2016," Diplomat, 17 February 2016.

26. David B. Larter, "US Coast Guard to Release New Heavy Icebreaker RFP," Defense News, 1 March 2018.

27. Jeff Desjardins, "This Infographic Shows How Gigantic the Arctic's Undiscovered Oil Reserves Might Be," Business Insider, 7 April 2016. 
28. David Axe, "Russia Is Sending S-400 Air Defense Systems to the Arctic (and That's Just for Starters)," The Buzz (blog), National Interest, 26 March 2019.

29. China's Arctic Policy: The State Council Information Office of the People's Republic of China (Beijing: State Council Information Office of the People's Republic of China, 2018).

30. W. Meier et al., 2018: Sea Ice Outlook Interim Post-Season Report (Fairbanks, AK: Arctic Research Consortium of the United States, 2018).

31. Sophie des Beauvais, "Map Room: Arctic Militarization," World Policy Journal 32, no. 2 (Summer 2015), https://doi.org/10.1177/0740277515591534.

32. Mark Episkopos, "How Russia Is Getting Ready for War in the Arctic," The Buzz (blog), National Interest, 1 December 2018.

33. Bob Weber, "Russia Is Beefing Up Its Presence at the North Pole—and Canada Has Little to Compare," Canadian Press, 10 February 2019.

34. Partial Revised Submission of the Russian Federation to the Commission on the Limits of the Continental Shelf in Respect of the Continental Shelf of the Russian Federation in the Arctic Ocean: Executive Summary (Moscow: Russian Federation, 2015), 6.

35. Report to Congress: Department of Defense Arctic Strategy (Washington, DC: Office of the Under Secretary of Defense for Policy, Department of Defense, 2019), 5.

36. Nengye Liu, "What Are China's Intentions in Antarctica?," Diplomat, 14 June 2019 .

37. Stephanie Pezard, The New Geopolitics of the Arctic: Russia's and China's Evolving Role in the Region (Santa Monica, CA: Rand, 2018), 3, https://doi.org/10.7249/CT500.

38. Claire Young, "What's China Up to in Antarctica?," Strategist, 20 September 2018.

39. Lu Hui, "Full Text: China’s Arctic Policy," XinhuaNet, 26 January 2018.

40. Marvin Gonzalez, "Paradox of Progress: The Arctic and Antarctica," Office of the Director of National Intelligence, accessed 24 April 2019.

41. The first scholarly indication of possible future hostilities in the Arctic and Antarctic over resources was suggested in 1986, noting that success in such conflict would require specialized military personnel due to the environmental challenges of operating there. John Keegan and Andrew Wheatcroft, Zones of Conflict: An Atlas of Future Wars (New York: Simon \& Schuster, 1986), xiv, 10, 12, 60, 132, 143, 146.

42. Gautier et al., "Circum-Arctic Resource Appraisal."

43. Perry Carter et al., "Russia's 'Smart Power' Foreign Policy and Antarctica," Polar Journal 6, no. 2 (2016): 259-72, https://doi.org/10.1080/2154896X.2016.1257102.

44. Rebecca Pincus, "China’s Polar Strategy: An Emerging Gray Zone?," Diplomat, 7 July 2018.

45. "United States Antarctic Program," National Science Foundation, accessed 24 April 2019.

46. The number of facilities in the Antarctic ebb and flow based on time of season (i.e., many are only open during the summer months), funding, logistics, and ability to maintain infrastructure. Benjamin Elisha Sawe, "Countries with Antarctic Research Stations," World Atlas, 26 November 2018.

47. The Antarctic Treaty, AR-AU-BE-CL-FR-JP-NZ-NO-ZA-USSR-UK-US, 15 October 1959. The treaty went into effect in 1961, and there are now 54 signatories. For the most up to date information on the treaty, see "The Antarctic Treaty," Secretariat of the Antarctic Treaty.

48. Gonzalez, "The Arctic and Antarctica."

49. Anne-Marie Brady, China's Expanding Antarctic Interests: Implications for Australia (Barton, Australia: Australian Strategic Policy Institute, 2017), 13-16; and Pincus, "China’s Polar Strategy."

50. Charles K. Ebinger and Evie Zambetakis, "The Geopolitics of Arctic Melt," International Affairs 85, no. 6 (2009): 1215-32.

51. Erika Spanger-Siegfried et al., The US Military on the Front Lines of Rising Seas: Executive Summary (Cambridge, MA: Union of Concerned Scientists, 2016); and Meghann Myers, "Rising Oceans Threaten to Submerge 128 Military Bases: Report," Navy Times, 29 July 2016. 
52. Department of Defense 2014 Climate Change Adaptation Roadmap (Washington, DC: Department of Defense, 2014); and Tuan N. Pham, "China's Activities in the Polar Regions Cannot Go Unchecked," U.S. Naval Institute Press Proceedings 145, no. 3 (March 2019).

53. "China Island Tracker," Asia Maritime Transparency Initiative, Center for Strategic and International Studies, accessed 25 April 2019.

54. Rafael Bernal, "House Funding Bill Scraps Arctic Icebreaker Program," Hill, 13 December 2018.

55. Leslie Hook and Benedict Mander, "The Fight to Own Antarctica," Financial Times, 24 May 2018.

56. Chad Michael Briggs, "Climate Security, Risk Assessment and Military Planning," International Affairs 88, no. 5 (2012): 1049-64, https://doi.org/10.1111/j.1468-2346 .2012.01118.x.

57. "Marine Rotational Force-Darwin," U.S. Marines Corps (official website), accessed 25 April 2019.

58. "Exercise BALTOPS 2018 Enhancing Interoperability among NATO Allies and Partners in Baltic Region," Navy Live (blog), 11 June 2018; and "Saber Strike 2018," U.S. Army Europe (official website), accessed 25 April 2019.

59. "Coast Guard Stands Up Forward Operating Locations for Arctic Shield 2015," Coast Guard News, 1 July 2015.

60. Mary Ilyushina and Frederik Pleitgen, "Inside the Military Base at the Heart of Putin's Arctic Ambitions," CNN, 5 April 2019.

61. Report to Congress: Department of Defense Arctic Strategy, 8.

62. The term dwell time refers to the time a member of the armed forces or unit spends at the permanent duty station or home port after returning from deployment. Consider that a MEU operates in three cycles: first, predeployment "work ups"; second, actual deployment; and third, the dwell time from the deployment. Dwell is an important component of the deploy-to-dwell calculation that required the DOD to release a new policy increasing the ratio from 1:1 to 2:1 as a result of servicemember fatigue. See Overseas Service: Assignments, Details, and Transfers, Army Regulation 614-30 (Washington, DC: Department of the Army, 2016), 18.

63. "Harry S. Truman Strike Group Enters Arctic Circle, Prepares for NATO Exercise," U.S. Navy (official website), 19 October 2018.

64. Megan Eckstein, "Navy May Deploy Surface Ships to Arctic This Summer as Shipping Lanes Open Up," USNI News, 8 January 2019.

65. It takes a Boeing C-17 Globemaster III approximately five hours and a Lockheed C-130 Hercules about seven hours to fly to McMurdo Station. Italy, South Korea, and New Zealand also stage their logistical airlift support to Antarctic stations from the Christchurch airport. "Gateway to Antarctica," Christchurch Airport (official website), accessed 24 April 2019.

66. "821st Air Base Group," Peterson Air Force Base (official website), accessed 24 April 2019.

67. Under normal operating conditions, it would take a four-ship of Lockheed Martin F-22 Raptors at least three hours to reach the North Pole, requiring in-flight refueling support from several tankers (e.g., Boeing KC-135 Stratotanker, McDonnell Douglas KC-10 Extender, and/or Boeing KC-46 Pegasus).

68. Robert Orttung and Katherine Weingartner, Policy Memo 588, "U.S. Arctic Policymaking under Trump and Obama: Implications for Russia and China," PONARS Eurasia, April 2019.

69. Since 2001, the United States has spent more than $\$ 200$ billion on security assistance just to Afghanistan and Iraq. For detailed info, see "Security Aid Dashboard," Security Assistance Monitor, accessed 16 July 2019.

70. Atle Staalesen, "Russia Says Its Radio-Electronic Shield Now Covers the Arctic," Barents Observer, 21 May 2019.

71. Drew Hinshaw and Jeremy Page, "How the Pentagon Countered China's Designs on Greenland," Wall Street Journal, 10 February 2019. 
72. Alex Brockman, "Life North of 80: Meet the People Living at the Top of the World," CBC News, 3 September 2018.

73. Patrick James, Canada and Conflict: A Hard-Hitting Look at Canadian Security Post9/11, from the Afghanistan War to US Relations and Arctic Sovereignty (New York: Oxford University Press, 2012).

74. Erica Cirino, "Overfishing of Krill Is Disrupting Antarctic Food Chains," Pacific Standard, 30 March 2018.

75. James K. Wither, "Svalbard: NATO's Arctic 'Achilles' Heel'," RUSI Journal 163, no. 5 (2018): 28-37, https://doi.org/10.1080/03071847.2018.1552453.

76. Thomas Nilsen, "Northern Sweden and Finland Play Key Role as NATO Kicks Off Trident Juncture," Barents Observer, 23 October 2018; and "Russia Denies Disrupting GPS Signals during NATO Arctic Exercises," Guardian, 12 November 2018.

77. Orttung and Weingartner, "U.S. Arctic Policymaking under Trump and Obama."

78. Jeff D. Colgan, "Climate Change and the Politics of Military Bases," Global Environmental Politics 18, no. 1 (2018): 33-51, https://doi.org/10.1162/GLEP_a_00443.

79. Cruzen, "Polar Operations," 1. 


\title{
Defense and Deterrence on NATO's Northern Flank Strengthening the U.S. Marine Corps' Role in Europe
}

\section{Zsofia Budai}

\begin{abstract}
Current North Atlantic Treaty Organization (NATO) efforts to address security threats in the alliance's northern flank are insufficient in light of Russia's aggressive actions and military buildup near the European border. The U.S. Marine Corps is uniquely suited to deterrence and defense in this region due to its doctrine, capabilities, and strong historical relationship with Norway. To strengthen the security situation in this key geostrategic area, the Marine Corps should expand its rotational presence in Norway, deploy a rotational force to Iceland, increase its participation in European training and exercises, and maintain high standards of cold weather preparedness.
\end{abstract}

Keywords: Norway, North Atlantic Treaty Organization, NATO, Russia, High North, Arctic, rotational forces, prepositioning program, Marine Rotational Force-Europe, MRF-E, Marine Corps Prepositioning Program-Norway, MCPP-N

$\Delta$

n early October 2018, the 24th Marine Expeditionary Unit (24th MEU), embarked aboard the Iwo Jima Amphibious Ready Group (ARG) and set sail from North Carolina toward Iceland and Norway to take part in Trident

Zsofia Budai joined the Foreign Service, U.S. Department of State, in 2010 after completing a BS in foreign service and an MA in Russian and East European studies at Georgetown University. She has served at the U.S. Embassy Moscow, Russia (2010-12); the U.S. Consulate General in Karachi, Pakistan (2013-14); and the U.S. Mission to NATO in Brussels, Belgium (2015-18), before returning to Moscow for her current assignment. This article was part of the requirements for her master of military studies program at Marine Corps University's Command and Staff College, from which she graduated in June 2019. The views expressed in this article are the author's own and do not represent the official position of the U.S. Department of State. 
Juncture 2018, the largest exercise that the North Atlantic Treaty Organization (NATO) had held in decades. ${ }^{1}$ With approximately 50,000 participants from all 29 NATO members — plus partners Sweden and Finland-Trident Juncture offered a unique opportunity for the alliance to rehearse the defense of its territory on the frigid waters and over the icy terrain that characterizes northern $\mathrm{Eu}$ rope. Since Marines from II Marine Expeditionary Force (II MEF) constituted the bulk of the 14,000 U.S. servicemembers participating in the exercise, the spotlight on them was especially strong: How would America's rapid response force demonstrate its ability to come to the aid of European allies in the event of a crisis? ${ }^{2}$ Despite some weather-related setbacks (in the United States, not Norway), the Marine Corps put in an impressive performance; by sending such a large number of troops, equipment, and vehicles to the exercise, II MEF proved how seriously it would take any aggression directed toward NATO.

The threat of such aggression is very real; the 2018 National Defense Strategy (NDS) identifies Russia and China as the central challengers not just to U.S. prosperity and security but also to the prosperity and security of American allies and partners. ${ }^{3}$ Russia's great power aspirations and disregard for international law and institutions have become abundantly clear since 2014, as has the country's focus on rebuilding its military strength and pursuing a doctrine of what some experts call "new generation warfare" or "hybrid warfare." ${ }^{4}$ In response, the U.S. military has recommitted itself to deterring — and, if necessary, defending against-Russian aggression in Europe, as well as slowly relearning some of the lessons built up in the Cold War but lost during the peace dividend that followed. The European Deterrence Initiative (EDI, formerly called the European Reassurance Initiative) has reflected these priorities by providing additional funding for U.S. rotational units, exercises, infrastructure improvements, and more, with $\$ 6.5$ billion approved for FY2019 and $\$ 5.9$ billion requested for FY2020. ${ }^{5}$

Like the other Services, the Marine Corps has recognized the need to adapt its tactics, techniques, and procedures (TTPs) — and possibly its force posture-in the face of the changing international security environment. As General Robert B. Neller, the 37th Commandant, testified before the Senate in April 2018, "The ascendant threats posed by revisionist powers and rogue states require change - we must become more lethal, resilient and as a consequence, a more capable deterrent." ${ }^{3}$ Heeding this directive, Marine Corps leaders have taken the initial steps to adapt and modernize the force, reevaluating how it can fight and win as part of a Joint Force against a near-peer adversary. ${ }^{7}$ Although the bulk of the Marine Corps' planning efforts have focused on the Indo-Pacific Command (INDOPACOM) area of responsibility, the Service has not neglected the European theater; it has deployed forces to Norway on a rotational basis 
since early 2017 and has increased its participation in various exercises, especially in northern Europe.

Nonetheless, the Marine Corps' efforts in this area are currently insufficient to address Russia's ongoing aggression and increasingly threatening behavior toward the United States and its allies. During the past decade, President Vladimir Putin has rebuilt the Russian military, enabling it to invade and seize parts of two neighboring nations. ${ }^{8}$ He has also demonstrated Russia's ability to meddle in other countries' internal affairs, including in the 2016 U.S. elections. ${ }^{9}$ Although U.S. and NATO leaders have taken substantial steps to reinforce the alliance's eastern flank, especially in the Baltic region, they have not paid enough attention to NATO's relatively unprotected north, which remains quite vulnerable. Strengthening the Marine Corps' presence in and familiarity with this region would significantly strengthen the security situation in Europe, thereby contributing to peace and stability in the entire Euro-Atlantic area.

To establish how and why the Marine Corps is best suited to defense and deterrence in Europe's northern flank as part of the Joint Force and within the NATO framework, it is important to examine the following: the contributions that the Marine Corps has made to European security since the 1970s through today; the security challenges that Russia poses to northern Europe and the possible points of friction; and the unique capabilities that the Marine Corps brings to deterrence and defense in Europe's High North. ${ }^{10}$ By investing in increased Marine Corps personnel and capabilities in this region, the United States would be better positioned to maintain its geostrategic interests in the North Atlantic.

\section{The Marine Corps in Europe: From the 1970s to Today}

The Marine Corps' contribution to planning for the defense of European allies dates back to the 1970s, when the Soviet Union's Cold War military buildup on the Kola Peninsula prompted policy makers within both NATO and the United States to look at options for the reinforcement of northern Europe. By this time, the Soviet Union had amassed much of its military capabilities in the north, including ballistic missile submarines, air defense systems, and two motorized rifle divisions permanently positioned on the Norwegian border. ${ }^{11}$ Western experts warned that NATO's northern flank was vulnerable to Soviet exploitation, and a joint American-Norwegian study group was put together in the late 1970 s to consider U.S. military options for the region. ${ }^{12}$

U.S. Marines had participated in NATO exercises in Norway as far back as 1964, but it was not until the mid-1970s that the 4th Marine Amphibious Brigade (4th MAB) — under the leadership of General Alfred M. Gray Jr., then a one-star-began to train seriously for a potential conflict by deploying 6,000 Marines to exercise in Norway and Denmark. ${ }^{13}$ In 1978, Secretary of Defense 
Harold Brown formally tasked the Department of the Navy with planning for "the rapid reinforcement of Norway with an air-lifted, brigade-sized force" and prepositioned equipment within the country. ${ }^{14}$ Secretary Brown recognized the existential threat the Soviet buildup posed for the entire North Atlantic alliance, and he and his military advisors saw the Marine Corps as the most appropriate Service for deterrence and defense in the Arctic. This was a very different mission for a Corps that had just recently spent a decade fighting insurgents in the jungles of Vietnam, but the lesson was clear: the international security environment had changed, and the Marine Corps would have to take on new responsibilities, to include contributing to NATO's collective defense.

As a result, the United States and Norway signed a memorandum of understanding (MOU) in 1981 that codified the Marine Corps' role in the defense of northern Europe, establishing that it could deploy a brigade if necessary and preposition heavy equipment and supplies "to facilitate the rapid transfer of the MAB in a conventional Alliance reinforcement of Norway." ${ }^{15}$ Its mission would be to defend airfields and provide forces for a naval campaign in the Norwegian Sea, ideally working together with British and Royal Netherlands Marine Corps, who regularly conducted winter training in Norway but had no similar bilateral agreements in place. ${ }^{16}$ During the course of the 1980s, U.S. Marines focused on preparing for this new mission both at home and abroad, devoting considerable resources to maintaining readiness for cold weather operations should conflict arise in the High North. The Marine Corps Mountain Warfare Training Center in California led the efforts to train Marines for winter warfare and outfit them with the right gear; 4th MAB (later called the 4th Marine Expeditionary Brigade or 4th MEB) then put these skills to the test during its frequent exercises in Norway. ${ }^{17}$ Although the Soviet Union collapsed 10 years after the MOU was signed, the Marine Corps had by then demonstrated that it could make a significant contribution to the defense of the NATO alliance by specializing in rapid response to crises and cold weather operations on land and in the littorals. As historian Colonel Joseph H. Alexander (Ret) wrote in 1984, "The Marines actively sought this task [to reinforce Norway] at a time of transition in roles and missions - a time of decreasing amphibious lift and increasing commitment to 'rapid deployment' tasks." 18

Concurrently, the Marine Corps was also working with the Navy to establish a Service component command in Europe. This came to fruition in 1980 with the creation of Headquarters, Fleet Marine Force, Europe, initially located in London and moved to Germany in $1993 .{ }^{19}$ After the end of the Cold War, the command (renamed Marine Forces Europe, or MARFOREUR, in 1994) focused on facilitating counterinsurgency efforts in the Middle East, although Marines were also deployed to Europe in 1999 as part of the NATO bombing campaign and follow-up peacekeeping operations in Kosovo. ${ }^{20}$ Since 
2015, what is now MARFOREUR/AF stands as a two-star command overseeing 1,500 Marines and facilitating engagements throughout the European and African theaters. ${ }^{21}$ Within this area of responsibility (AOR), the Marine Corps maintains the Special Purpose Marine Air-Ground Task Force-Crisis Response-Africa (SPMAGTF-CR-AF) in Spain and the Marine Rotational Force-Europe (MRF-E) in Norway; the Marine Corps ended the Black Sea Rotational Force (BSRF) in Romania in late 2018 after eight years in the region to focus on the High North. ${ }^{22}$

Although the Marine Corps' mission and priorities in Europe have evolved, its relationship with Norway has remained unbroken since the 1970s. Even after the Cold War, the Marine Corps continued to store prepositioned equipment there and maintained plans for the defense of northern Europe, despite questions about whether these measures were necessary since the Soviet threat had disappeared. ${ }^{23}$ The 1981 MOU remained in force until 2005, when it was rewritten to focus exclusively on the prepositioning program, eliminating any specific references to how a brigade (or other unit) would deploy to Norway. ${ }^{24}$ The stated goal of what was then formally christened the Marine Corps Prepositioning Program-Norway (MCPP-N) remained supporting the country's reinforcement; it specified that the host nation would assume responsibilities for equipment security and general maintenance through a cost-sharing agreement. Currently stored in six caves and two storage facilities in the Trøndelag region of central Norway, MCPP-N equipment and supplies can "support the stand-up of one or more MAGTFs conducting low to mid-intensity conflicts," according to the 2015 edition of the Marine Corps' Prepositioning Programs Handbook. ${ }^{25}$

Equally significant was the Marine Corps' decision to deploy a rotational force to Norway, beginning in January 2017 with about 300 Marines (increased to 700 in October 2018). ${ }^{26}$ Then-MARFOREUR/AF commander Major General Niel E. Nelson explained that the deployment had a number of benefits: it strengthened U.S. commitment to European security, it provided fantastic cold weather training opportunities, and it allowed Marines to better mobilize in an emergency - the unstated emergency presumably caused by Russia. Since then, Norwegian and American officials have regularly praised MRF-E as an important initiative for both the Marine Corps and the host nation in an uncertain environment. ${ }^{27}$ "We are very pleased with the rotation of the U.S. Marine Corps in Norway. This strengthens Norway, Norwegian troops, and it strengthens NATO. The security environment is more serious. One consequence is that we must strengthen security in the North Atlantic again," concluded Norwegian minister of defense Frank Bakke-Jensen in July 2018. ${ }^{28}$ Currently, the 700 Marines from II MEF train in two locations during their six-month rotations: Trøndelag (with the Norwegian Home Guard) and Setermoen (with the Norwegian Army). 
Map 1. Marine Corps Prepositioning Program-Norway storage locations

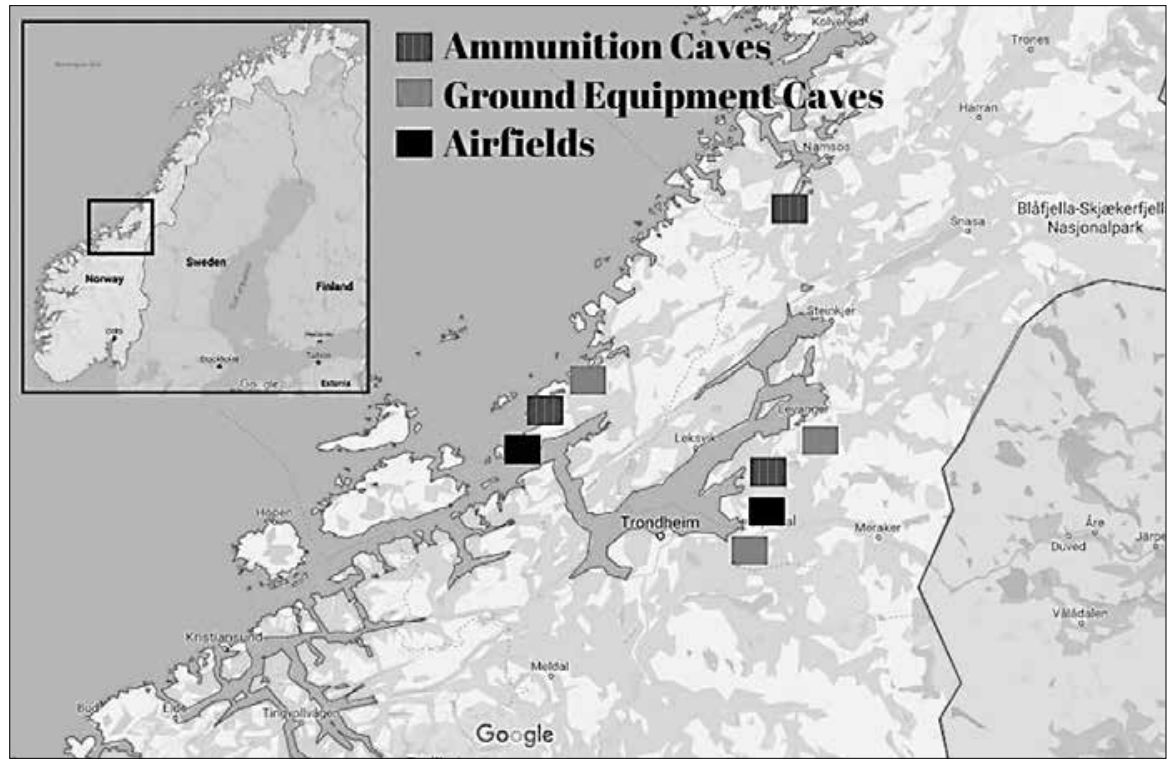

Map courtesy of the author, adapted by MCUP.

Map 2. Location of rotational Marine Corps units

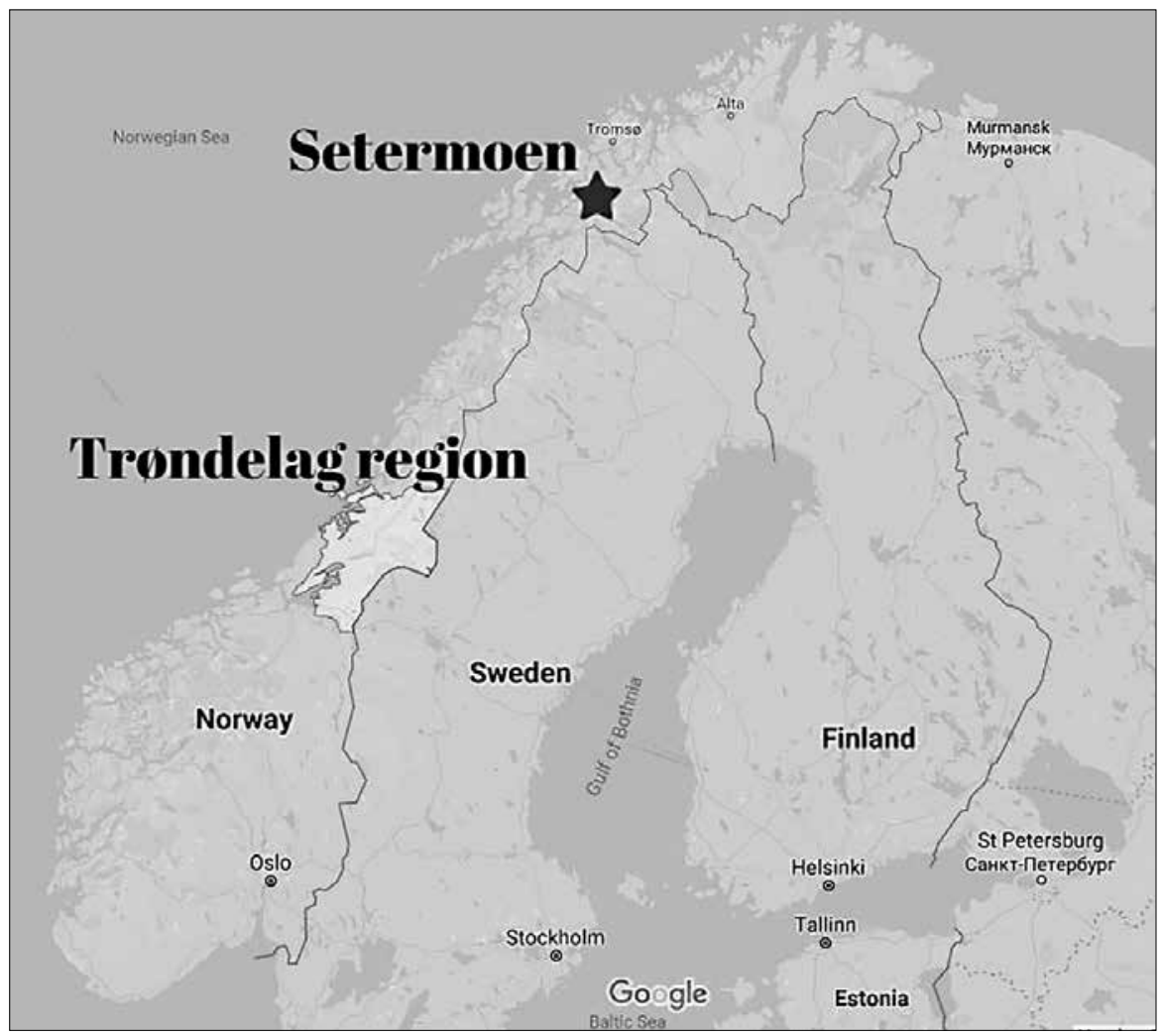

Map courtesy of the author, adapted by MCUP. 
In light of its renewed focus on northern Europe, how well positioned is the Marine Corps to deal with the challenges that Russia poses to transatlantic security? To answer that question, it is first necessary to examine Russia's current foreign policy ambitions and military capabilities, especially in the High North and Arctic region.

\section{Russian Threats to European Security: Possible Friction Points in the High North}

The NDS's focus on great power competition acknowledges an important reality: "Russia seeks ... to shatter the North Atlantic Treaty Organization and change European and Middle East security and economic structures to its favor." ${ }^{29}$ Since Putin's return to power in 2012, many of Moscow's concrete foreign policy objectives—-both stated and implied — have been driven by a desire to undermine the West and break the transatlantic bond between Europe and the United States. In the past few years, the Kremlin has invested significant resources into modernizing the Russian armed forces and developing new capabilities; Russia's defense spending rose steadily until it dropped in 2017 due to a weaker economy. ${ }^{30}$ Emboldened by Russia's advances in Ukraine and more confident in his country's military might, Putin seems willing to risk increased tensions with the West to keep the United States and its European allies off balance.

Official statements and publications from the Kremlin identify NATO as the top external threat to Russia's national security. Both its 2014 Military Doctrine and 2015 National Security Strategy criticize NATO expansion and what they call the build up of NATO forces near the Russian border; the latter also specifically establishes securing great power status as one of the country's long-term objectives. ${ }^{31}$ Translating this doctrine into the operational and tactical levels, "almost everything that the Russian military has done in the recent past seems aimed at confronting and challenging NATO," noted U.S. Admiral James G. Foggo III, commander of NATO's Allied Joint Force Command Naples, and his coauthor, Alarik Fritz, in a recent paper. ${ }^{32}$

What does this mean for NATO's northern flank? Russia has demonstrated a strategic interest in the Arctic and the High North, and it has developed the corresponding capabilities to project power and threaten the sea lines of communication (SLOCs) in the North Atlantic. Its Northern Fleet Joint Strategic Command military district was stood up in 2014 specifically to focus on the northern areas; it is centered around the Northern Fleet, which a 2017 Defense Intelligence Agency (DIA) report assesses as Russia's most capable naval force. ${ }^{33}$ General Valery V. Gerasimov, chief of the Russian General Staff, has stated that his objectives are to build up air and ground forces as well as air defense systems 
within this command as part of a general policy emphasizing the importance of the Arctic. ${ }^{34}$

Both the United States and Norway have expressed concerns about Russian military buildup, activities, and exercises in this region. Testifying before the Senate Armed Services Committee in 2018, Army General Curtis M. Scaparrotti, who served as U.S. European Command (EUCOM) commander and Supreme Allied Commander Europe (SACEUR) until recently, admitted that Russia has a "qualitative advantage in Arctic operations" and that "we're not keeping pace." ${ }^{35}$ Speaking at the May 2019 meeting of the Arctic Council, Secretary of State Michael R. Pompeo warned other members about the "pattern of aggressive Russian behavior here in the Arctic." The Kremlin "claims to have built 475 new military sites, including bases north of the Arctic Circle, as well as 16 new deep-water ports," he stated, adding that the United States is committed to countering this influence. ${ }^{36}$

The Norwegian Intelligence Service has also warned that "Russia has enhanced its ability to influence Norwegian on- and off-shore interests and activities, and current developments will also impact on Norway's ability to conduct operations on and out of Norwegian territory." ${ }^{37}$ More specifically, "Mobile platforms and long-range precision-guided weapons enhance Russia's ability to influence the sea and air axes into Norway. Critical Norwegian infrastructureboth civilian and military-is within reach of precision-guided Russian missile systems." 38 Although Norway strives to maintain a cooperative relationship with Russia as a neighbor and economic partner, Norwegian diplomats and military officers are tracking these developments closely. ${ }^{39}$ "Russian strategies for the Arctic still emphasize international cooperation. At the same time, we cannot rule out the possibility that Russia in a given situation will consider the use of military force to be a relevant tool, including in the High North," states Brigadier General Lars S. Lervik, commander of Norway's Brigade Nord. ${ }^{40}$

In light of the security situation and in line with its NATO obligations, Norway is making significant investments in its own military capabilities, including by purchasing Boeing P-8 Poseidon maritime patrol aircraft and 52 Lockheed Martin F-35 Lightning II fighter aircraft from the United States. ${ }^{41}$ The Norwegian Army and Navy are also refocusing on the High North, with the former reestablishing units in the Finnmark region in northern Norway. ${ }^{42}$ Nonetheless, Norway remains a small country with a relatively small military, and thus looks to not only NATO but also the United States as a guarantor of its security. ${ }^{43}$ As a senior Norwegian diplomat admits, "Norway is reliant on outside support and allied reinforcement if the situation should require it." ${ }^{44}$ Given Norway's strategic location but relative distance from the rest of NATO (it shares no land border with any NATO members), the country's reinforcement 
poses a critical challenge for its allies, including the United States. Although neither NATO nor Norway wants a conflict with Russia-the alliance is actively pursuing a dual-track approach of both deterrence/defense and dialogue with Moscow - the best way to prevent one is to be prepared to win one. As was the case during the Cold War, the U.S. commitment to Norwegian security benefits both nations by helping maintain peace and stability in the region.

\section{U.S. Strategic Priority: Responding to Russian Aggression}

NATO has responded to the security challenges in Europe by undertaking the most significant reinforcement of the alliance's collective defense since the end of the Cold War; the United States has played a leading role in this reinforcement. EUCOM's 2018 posture statement emphasizes how its "focus has shifted from engagement and assurance to deterrence and defense" within its AOR; this has meant deploying additional Army, Navy, Air Force, and Marine Corps assets to maintain a credible deterrent force in Europe. ${ }^{45}$ General Scaparrotti told the Senate in 2018,

Our highest strategic priority is to deter Russia from engaging in further aggression and exercising malign influence over our allies and partners ... we are working to create a combat-credible posture in Europe that will underpin our deterrence. We are updating our operational plans to provide military response options to defend our European allies against Russian aggression. ${ }^{46}$

A year later, General Scaparrotti warned that "while the United States maintains global military superiority over Russia, evolving Russian capabilities threaten to erode our competitive military advantage, challenge our ability to operate uncontested in all domains, and diminish our ability to deter Russian aggression." ${ }^{47}$ General Tod Wolters, who took command of EUCOM in early May 2019, agreed with this assessment in his own Senate confirmation hearing, stressing that "deterring Russian aggression and supporting NATO's defense of the Euro-Atlantic area remain the most significant challenges facing USEUCOM." ${ }^{48}$

In practice, this has resulted in EUCOM augmenting both NATO's and individual nations' military capabilities through the five lines of effort identified in the EDI: increased presence, exercises and training, enhanced prepositioning, improved infrastructure, and building partnership capacity. The Department of Defense (DOD) has asked for-and Congress has approved-substantial increases in EDI funding during the past few years (from less than $\$ 1$ billion in FY2015 to $\$ 6.5$ billion in FY2019), although the FY2020 request dropped slightly to $\$ 5.9$ billion. $^{49}$ The Marine Corps has consistently received the small- 
est portion of EDI, in line with its (thus far) fairly limited presence in Europe; this can and should be reconsidered in the future. Although all Services benefit from the money allocated for general projects such as theater-wide joint reception, staging, onward movement, and integration enhancements, the bulk of the funding allocated specifically for the Marine Corps is directed toward the following (FY2019 figures):

- Marine Corps rotational force support (\$29.0 million): This allows rotational forces to "increase the scope and size of engagements with NATO allies and partners"; it also funds U.S.-based Marines deploying more frequently for exercises and engagements in Europe.

- Marine Corps enhanced prepositioning (\$7.3 million): This allows for increasing and improving the equipment included in MCPP-N..$^{50}$

Before evaluating the enhanced role that the Marine Corps should take on within the EUCOM AOR, the Service's mission, capabilities, and unique history must be taken into consideration. "The course of the Marine Corps through the twentieth century was charted by a desire to be a useful contributor to national defense, and the Corps regularly adapted its mission and organization to the exigency of the day," argues Major Ian T. Brown in his recent book on the history of maneuver warfare. ${ }^{51}$ It is essential for this adaptation to continue through the present, especially as U.S. troops pull out of the Middle East and Afghanistan, freeing them up to train and deploy elsewhere, per the priorities identified in the NDS. ${ }^{52}$

\section{A Stronger Role for the Marine Corps in Europe}

The Marine Corps' current doctrine and capabilities_combined with its historical relationship with Norway-render it uniquely suited for defense and deterrence in the High North; the leadership of the Marine Corps and the Joint Force should reinforce this as the Corps' primary mission in Europe. Above all, the presence of rotational forces in Norway and the continuation of the prepositioning program send a strong signal of U.S. commitment, indicating that Washington is serious about deterring aggression in the region and coming to the defense of allies if deterrence fails. While it is impossible to measure the extent to which deterrence works - adversaries are certainly not going to admit to changes in strategy or tactics due to certain U.S. or NATO actionsmaintaining a persistent presence in Norway sends a clear message about the Marine Corps' willingness and ability to act in the event of a crisis, helping ensure that such a crisis does not break out or escalate even if it does.

Nonetheless, the security situation in Europe remains precarious. As Russia continues its military buildup in the Arctic, the northern flank remains especially vulnerable without a lack of adequate investment in its defense. When 
it comes to ground forces within the broader European context, the focus of the U.S. military has been on Eastern Europe; since 2017, the U.S. Army has deployed rotational armored, combat aviation, and sustainment brigades to the region. ${ }^{53}$ It has also taken the helm of one of the four multinational battlegroups that make up NATO's Enhanced Forward Presence in Poland and the Baltic states. Overall, NATO has deployed four battalions in the Baltic Sea region, but none in Norway or the High North; as a result, the U.S. Army and NATO forces provide a level of deterrence in Eastern Europe that northern Europe lacks. Indeed, with the Army having committed so many resources to protecting NATO's eastern flank, the Marine Corps is well-positioned to be the Service to protect the north. If this sounds reminiscent of the U.S. strategy during the latter part of the Cold War, that is because it is, but history offers many useful lessons and the fact that Marine Corps' relationship with Norway is already strong also provides an advantage. Operations in Norway give the Corps an opportunity to continue honing a very specific mission and for Marines to develop a very specific set of skills: namely, operating in uniquely challenging, extremely cold weather environments.

"We haven't been in the cold weather business for a while," General Neller acknowledged in early 2018, adding that the return of great power competition necessitates that Marines regain the skills they have lost in this area if they are to conduct successful operations worldwide. ${ }^{54}$ The loss of institutional knowledge leaves the Service unprepared to tackle global conflicts, and the Commandant has thus renewed his focus on cold weather training and exercises, starting in the United States. ${ }^{55}$ The Marine Corps Task List (MCTL) emphasizes the need "to conduct combat operations as a component of a MAGTF or other task force in mountainous, high altitude, and cold weather environments," arguing that such operations "require specialized warfighting doctrine, training, and equipment." 56 The focus on Norway thus fits into the Commandant's greater vision of a Marine Corps that is trained to fight in the extreme conditions that characterize the High North.

The Marine Corps prides itself on being the nation's rapid reaction force; deploying to reinforce Norway and the High North in a crisis scenario would be consistent with its doctrine. ${ }^{57}$ The MAGTF's ability to deploy anywhere in the world with minimal preparation and sustain itself for up to 60 days renders the Marine Corps uniquely capable of responding to crises before they erupt into large-scale conflicts. In light of Russia's adoption of so-called new generation warfare (which includes gray zone activities and hybrid tactics), a full-scale conventional war in Europe is highly unlikely; the more probable scenario would initially involve smaller-scale disturbances or disruptions that Russia could then escalate if it so chose. ${ }^{58}$ Given its doctrine and training, the Marine Corps would be the most appropriate U.S. military force to respond 
Figure 1. Gen Robert B. Neller speaks with Norwegian soldiers in Setermoen, 2017

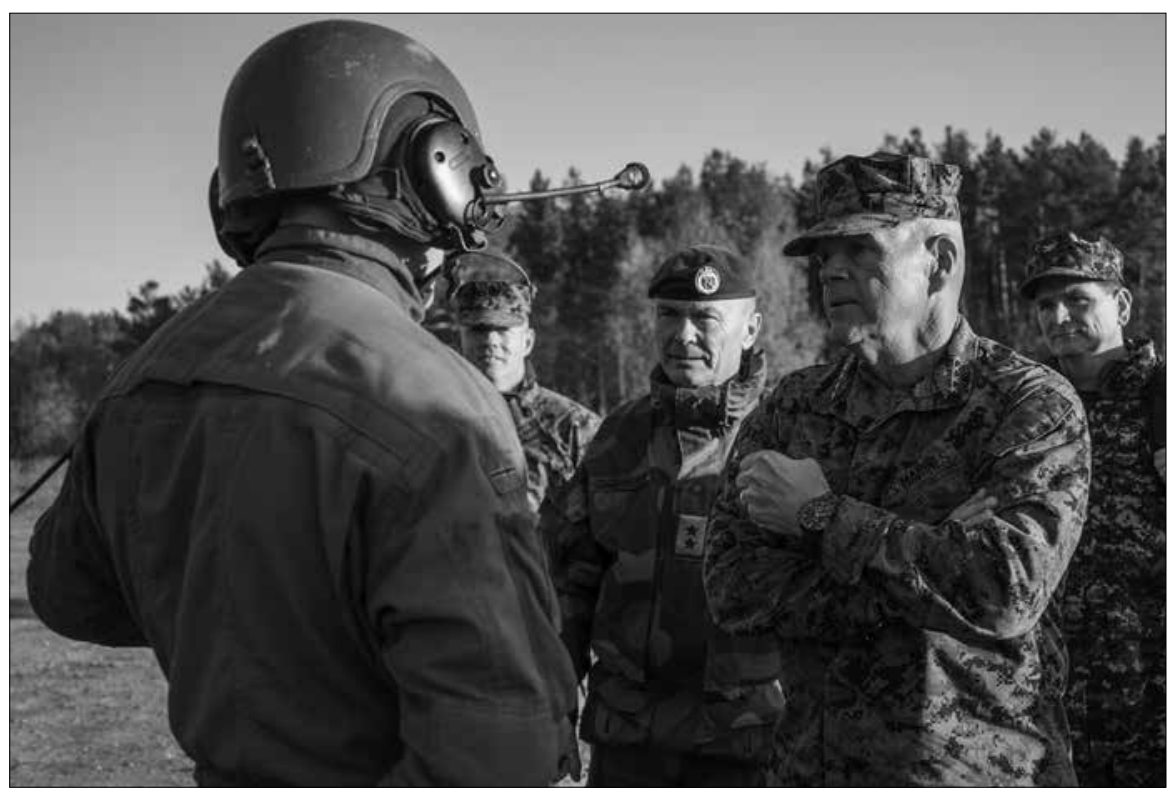

Official U.S. Marine Corps photo, courtesy Cpl Samantha Braun.

to such crises to control the situation, seize the initiative, and deescalate if possible.

However, all of this requires some key changes within the Marine Corps' approach to the EUCOM AOR to provide effective deterrence and defense. Namely, the Marine Corps must increase the presence of rotational forces in the region, as well as its preparedness for cold weather operations and interoperability with key NATO allies and partners. This not only adheres to the NDS's focus on great power competition and stronger alliances, but it also falls in line with the strategy's call for dynamic force employment (DFE), which "prioritize[s] maintaining the capacity and capabilities for major combat, while providing options for proactive and scalable employment of the Joint Force."59 Indeed, EUCOM commander General Tod Wolters recently highlighted this concept as part of his prepared testimony before the Senate, stating that dynamic force employment

complements USEUCOM's permanent, forward-stationed forces; balancing the two is an effective way to increase combat capability while minimizing costs. . . . DFE provides episodic presence of additional, rapidly-deployable forces that bolster USEUCOM's combat capability, operational flexibility and deterrent posture. These limited-duration deployments allow a more balanced global force posture while increasing readiness and interoperability. ${ }^{60}$ 
Russia's aggressive actions and military buildup near NATO's borders are likely to continue during the course of the next decade. As Secretary of State Pompeo stated recently, the Arctic "has become an arena for power and for competition," all the more so because reductions in sea ice are opening new passageways that Russia hopes to control in both the short and long term. ${ }^{61}$ With the vulnerabilities that still exist on the northern flank-which could ultimately threaten stability in the larger North Atlantic area-a relatively small increase in the U.S. Marine Corps presence in Norway (as well as in Iceland) would be a cost-effective way to improve the security situation in the region. Accordingly, a more robust role for the Marine Corps should include four essential elements, which are outlined below.

\section{Element \#1: Increase Size of Rotational Force in Norway}

The Marine Corps should further increase the size and strength of the rotational unit in Norway; it should deploy all elements of a MAGTF-command, ground, aviation, and logistics — to provide for more effective training based on real-life combat scenarios. Maintaining an infantry battalion (as is the current case) is valuable, but the key to the Marine Corps' success lies in the MAGTF; if a crisis were to occur, having a MAGTF in theater would allow for a much faster and more effective response, as that particular unit would already be well integrated with host nation and other NATO forces. Furthermore, the challenges posed by the harsh climate and topography require that all elements of a MAGTF train and acclimate prior to any major operation; this is especially critical for aviation, as operating and maintaining aircraft in such conditions requires prior experience doing so. A larger unit could also make better use of the equipment and vehicles stored in the MCPP-N locations, which are only occasionally pulled out for certain exercises and training scenarios. Given the significant investment that both the United States and Norwegian governments have already made in this program, deploying more Marines to the region would ensure a better return on this investment.

Of course, further increasing the size of MRF-E would require an affirmative decision by the Norwegian government, which has extended the mission (in its current state) for the next five years and will reevaluate its future in 2022. ${ }^{62}$ Norwegian diplomats stress that, although there is broad political support for the rotational force, expanding it is not currently on the agenda. ${ }^{63}$ Nonetheless, changes in the security situation in the Arctic, as well as indications from the Marine Corps about its willingness to take on a larger mission, could quickly change the political calculus. Furthermore, as the various MRF-E rotations build positive relations with their host communities and continue to prove their value to the Norwegian Armed Forces, they pave the way for building even more public support for such a decision. Norway's Brigadier General 
Figure 2. Marine Rotational Force-Europe hikes with a combat load during Exercise White Ulfberht in Setermoen, Norway, 14 January 2019

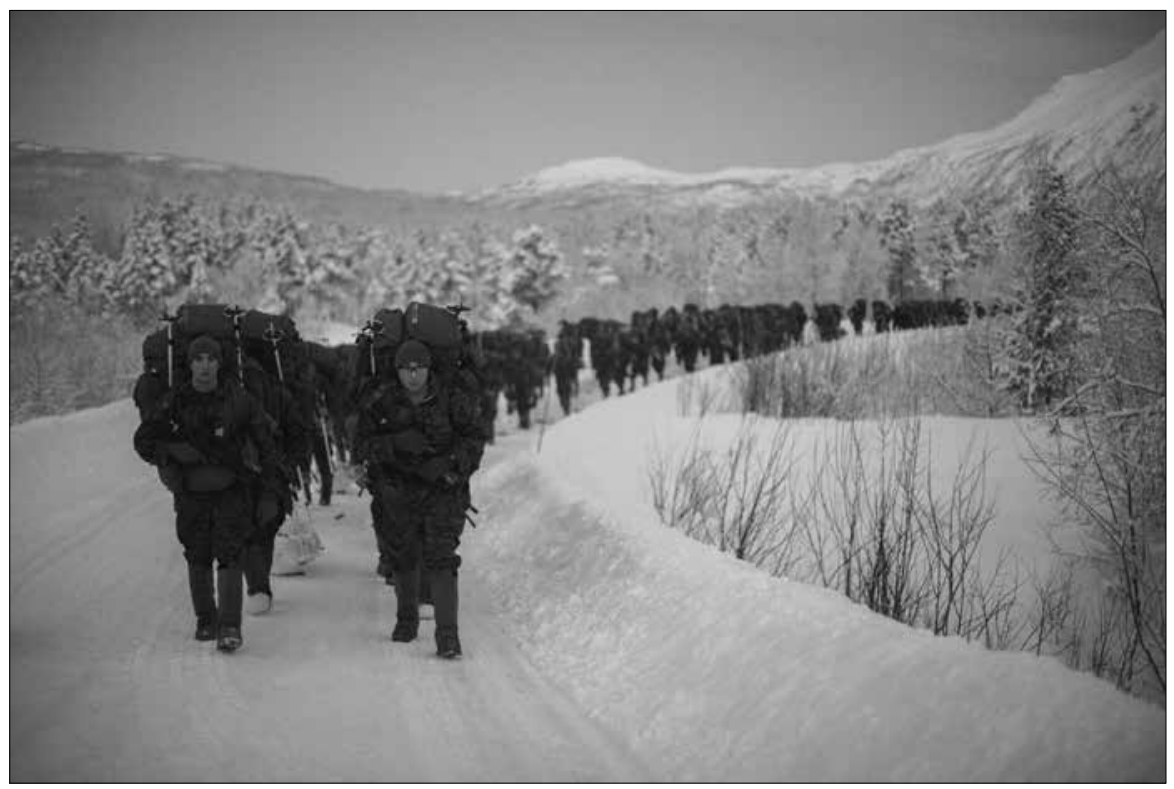

Official U.S. Marine Corps photo, courtesy Cpl Ashley McLaughlin.

Lervik supports expanding MRF-E to include artillery, as well as fixed-wing and rotary-wing aviation, to "increase both the deterrence and interoperability effects." ${ }^{\circ 4}$

\section{Element \#2: Deploy a Rotational Force to Iceland}

If the Marine Corps is truly committed to securing NATO's northern flank, it must think beyond Norway and consider other places its presence would be beneficial for deterrence and defense, as well as for effective cold weather training. A possible option would be to deploy a small rotational force to Iceland, a NATO member that maintains no standing military but has had a strong relationship with U.S. armed forces in the past. In fact, the 1951 bilateral defense agreement stipulates that the United States should "make arrangements regarding the defense of Iceland" is still in force. ${ }^{65}$ Despite leaving the country in 2006, the U.S. Navy recently returned to Iceland; it is upgrading Naval Air Station Keflavik and deploying P-8 Poseidon aircraft for maritime surveillance and patrolling. ${ }^{66}$ Given Iceland's geostrategic location and the critical role it would play in the defense of North Atlantic SLOCs, the Marine Corps should consider contributing to a Joint Force effort to strengthen the nation's security posture.

With the Navy having already laid the initial groundwork for a larger U.S. military presence, the Marine Corps could contribute a small rotational force 
to train with the Icelandic Police and provide additional proof of the U.S. commitment to the North Atlantic. In fact, Marines from 24th MEU gained some familiarity with Iceland during Trident Juncture 18; they rehearsed an airborne assault to secure key airfields and infrastructure before moving on to Norway for the main phase of the exercise. ${ }^{67}$ Iceland offers a climate and topography similar to that of Norway, thus Marines would also gain valuable cold weather experience while building relationships with another NATO ally.

\section{Element \#3: Participate in More Training Opportunities and Exercises in Europe}

In the past few years, the Marine Corps has gradually increased its level of participation in NATO and national exercises in Europe; it should continue to prioritize these opportunities to forge relationships and strengthen interoperability with allied nations. ${ }^{68}$ Exercises on the scale of Trident Juncture will be rare, but NATO members maintain a robust, year-round schedule of smaller exercises that would still benefit (and benefit from) Marines. These include winter exercises in Norway, Poland, and the Baltic region for cold weather training, as well as the annual maritime exercise BALTOPS. BALTOPS is especially valuable from the perspective of naval integration, as it combines air, maritime, ground, and amphibious operations to secure the Baltic Sea. In recent years, Marines from 26th MEU have participated. As Marine Corps commanders consider future MEU and MEB deployments, they should include engagements in the High North as critical components of their plans.

NATO partners Sweden and Finland have also stepped up their national exercise schedule in response to Russian aggression in the region; Marines took part in Aurora in 2017 (Sweden) and Arrow in 2018 and 2019 (Finland). Despite the fact that they are not NATO members, these two countries work closely with the alliance and share Norway's climate and topography, as well as some of Norway's security concerns. If the Marine Corps is to improve its ability to operate in the High North, building relationships with Sweden and Finland should be a key part of its strategy. Exercises (along with rotational deployments, as mentioned above) are still more cost-effective than permanently basing Marines in Europe; they also strengthen deterrence by demonstrating that the Marine Corps' ability to reinforce NATO's northern flank has not atrophied.

\section{Element \#4: Maintain High Standards of Cold Weather Preparedness in the United States}

As discussed earlier, the Marine Corps' focus on Norway fits within the larger effort to strengthen cold weather training and readiness within the Service. In addition to the rotational forces and military engagements in Europe, II MEF 
Figure 3. Marine Corps Prepositioning Program-Norway vehicles for an exercise in Norway

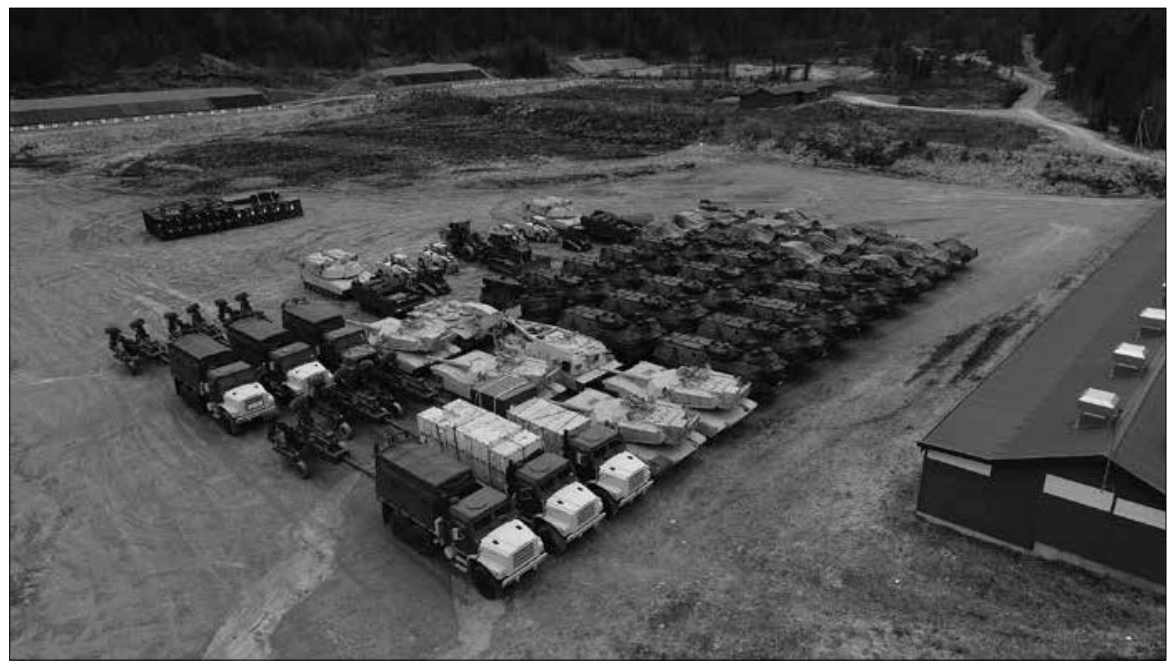

Official U.S. Marine Corps photo, courtesy 2dLt Brett Lazaroff.

should continue to spearhead the Marine Corps' efforts to maintain the appropriate standards of cold weather preparedness, which is a key priority for the Commandant. This starts at home, with training at the Mountain Warfare Training Center and at other military facilities in states such as Wisconsin and Alaska. It also requires investment into the right clothing, equipment, vehicles, and gear, some of which is still quite inadequate for extended use in harsh environments.

II MEF deputy commander Major General Stephen M. Neary emphasizes that the Marine Corps must be trained and equipped to conduct cold weather operations: "We're having a dialogue at the senior levels to make sure that we have that capability." ${ }^{69}$ Of course, it is neither realistic nor necessary to train every Marine in II MEF for this, but the Marine Corps should consider which units are the most likely to deploy to cold regions and invest in the appropriate training for them. The difficulties of operating in a cold weather environment are well-documented, and II MEF cannot afford to get caught unprepared for such operations.

\section{Lessons Learned: How European Deployments and Exercises Strengthen Both Marine Corps and Host Nation Capabilities}

American and Norwegian officers and diplomats agree on the value of maintaining a rotational force in Europe and deploying Marines to train and exercise in theater, pointing to how these initiatives benefit Norway, the United States, and NATO as a whole. Norway's Brigadier General Lervik argues that the lev- 
Figure 4. Marines participate in a snowmobile course in Norway

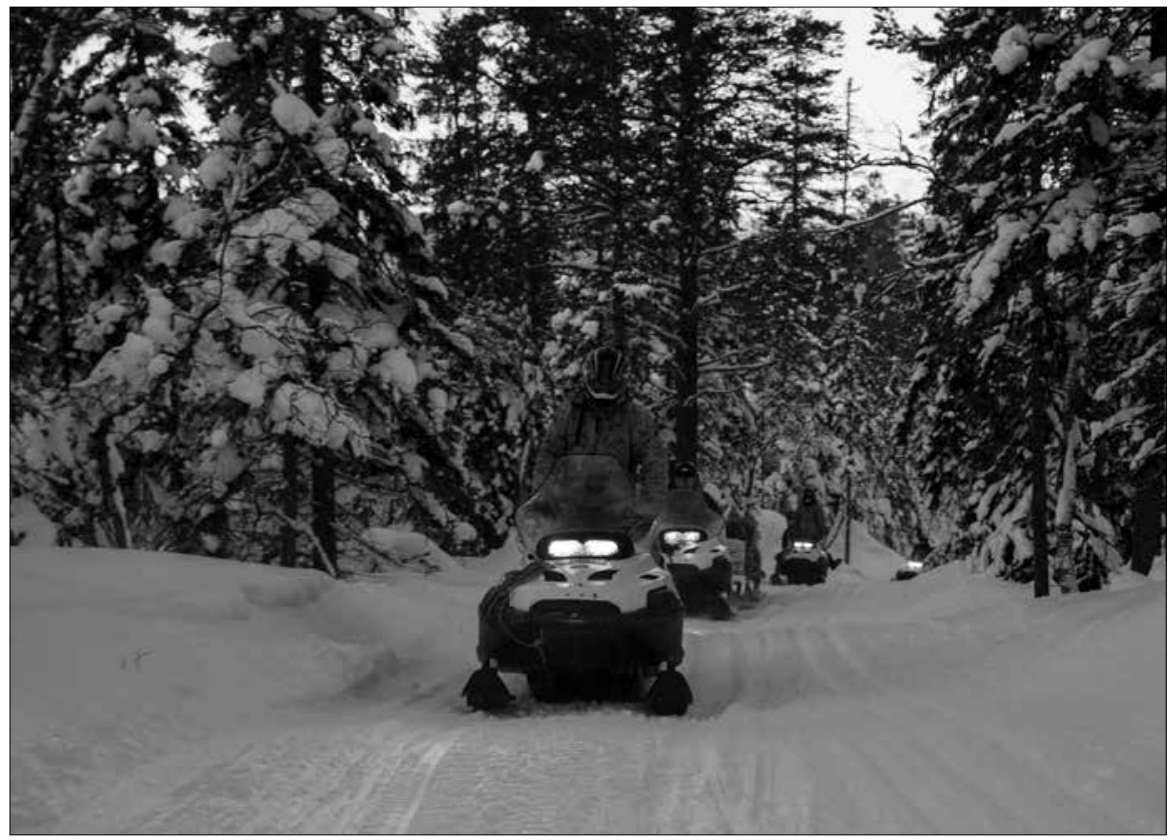

Official U.S. Marine Corps photo, courtesy Cpl Elijah J. Abernathy.

el of interoperability achieved between the Marine Corps and the Norwegian Armed Forces would be impossible without a rotational force on the ground. Marines and Norwegian soldiers train closely together, allowing them to establish common TTPs and maintain technical interoperability in areas such as logistics and communications. ${ }^{70}$ II MEF's Major General Neary agrees that MRF-E provides invaluable training for Marines, not least of all because it gives them an opportunity to build relationships with the host nation military and government. Essentially, it is an investment in the relationship so "they know that in a time of crisis they can count on us, and vice versa" because "you can't surge trust during a crisis." 71

The deployment of the rotational force has strengthened both the Marine Corps and the Norwegian armed forces. As a Norwegian diplomat explains, "to train with a group of people like the U.S. Marine Corps-they are very well trained, they have high standards, they are well-organized, they have good equipment-makes us better too."72 Major General Neary points to Norwegians' familiarity with and proficiency in cold weather operations as a major benefit for the Marines who work with them and learn from them. ${ }^{73}$

It is important to note that U.S. Marines are not the only ones who see the immense value of strengthening deterrence in NATO's north and training in Norway; both British and Dutch Royal Marines have long-established relationships with the country as well. Indeed, Gavin Williamson, who served 
Figure 5. Marines and Norwegian Army soldiers during Exercise White Ulfberht

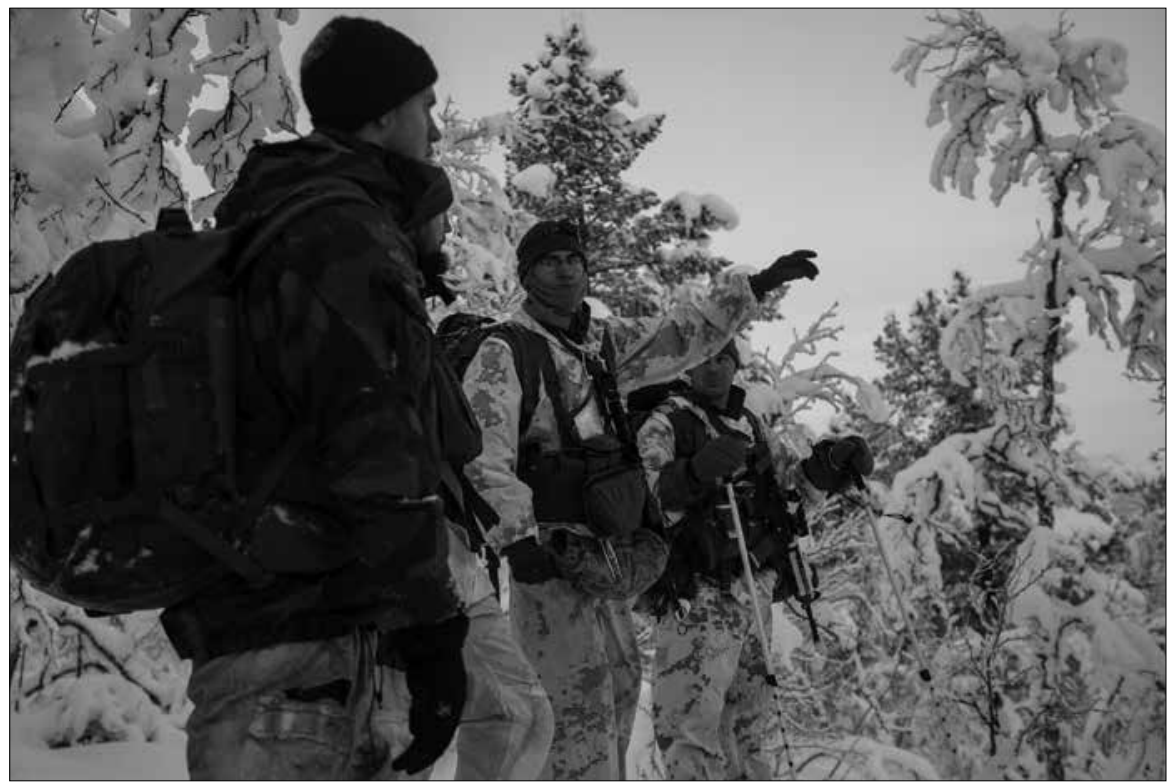

Official U.S. Marine Corps photo, courtesy Cpl Ashley McLaughlin.

as the British defense secretary until May 2019, detailed his country's new Defense Arctic Strategy, which commits one thousand Royal Marines to train in Norway each year, for a minimum of 10 years. ${ }^{74}$ The United Kingdom and the Netherlands are also making significant contributions to NATO's northern flank, recognizing that the region's vulnerability and strategic importance call for a stronger response. Through MRF-E, the Marine Corps is establishing closer relationships and building interoperability with other forces as well, creating the basis for an allied response to a potential security crisis. This cooperation between the United States, British, and Dutch Marines in Norway is one of NATO's greatest combination of amphibious and ground combat capabilities and a valuable force multiplier to each contributing nation and the alliance as a whole.

\section{Conclusion}

Speaking at NATO headquarters in Brussels in June 2019, then-Acting Secretary of Defense Mark T. Esper reconfirmed the U.S. commitment to its allies: "Whatever the form of Russian aggression, the United States will continue to lead NATO to adapt its deterrence and defense posture. . . . Our security guarantees have been the bedrock of European security for [70 years]. Those guarantees remain." 75 Both the National Security Strategy and the National Defense Strategy identify Russia as the greatest threat to transatlantic unity and 
security, clearly setting the top strategic priority for the U.S. military in Europe. EUCOM has put much of the additional funding provided by EDI during the past five years toward a significant reinforcement of American capabilities in the east, following NATO's lead. At the same time, the Marine Corps has deployed rotational units to Norway to mitigate some of the vulnerabilities on the northern flank, but this does not go far enough in addressing the serious security challenges that remain in the region in light of Russia's renewed focus on the Arctic. Indeed, the magnitude of the security challenges in the region demand that the Marine Corps invest more resources in this area. Increasing the size of MRF-E to include all MAGTF elements, deploying a small rotational force to Iceland, participating in more European exercises, and ensuring that II MEF units are prepared for cold weather operations would go a long way toward demonstrating that the United States is serious about the defense of NATO's northern flank in cooperation with other NATO Allies — and has the ability to carry out this defense if necessary. Effective deterrence is about demonstrating both the capability and the will to come to the aid of NATO allies, as General Scaparrotti pointed out in his testimony. ${ }^{76}$

Discussions about how the Marine Corps can and should contribute to European security are certainly reminiscent of similar debates from the 1970 s-80s, when the Department of Defense ultimately decided that the 4th MAB would be responsible for the reinforcement of Norway in the event of a conflict with the Soviet Union. Fortunately, the historical ties between the Marine Corps and the Norwegian armed forces have established the basis for their continued cooperation in the face of Russia's increasingly aggressive foreign policy and military activities. Although the bulk of the Marine Corps' attention and resources are being devoted to the Pacific, it cannot and should not ignore the security threats to NATO allies. Ensuring stability in Europe and deterring a conflict with Russia requires that the entire Joint Force maintain a high level of readiness in theater. Major General Neary argues that Russia is "an opportunistic adversary," looking to exploit any possible weakness in the U.S. force posture in Europe. "If Marines are to be the crisis response force for America, we can't just be Pacific focused-we must be global," he maintains. ${ }^{77}$

During the course of its history, the Marine Corps has been forced to adapt to the changing threat environment, often having to prove its continued relevance and significance along the way. The renewed focus on great power competition offers Marines both a challenge and an opportunity: they must relearn how to fight in cold weather environments, preparing to defend against a sophisticated, near-peer adversary by working with host nations and other forces. Nonetheless, the Marine Corps has proven time and again that it lives up to its reputation as a flexible, adaptable, and cost-effective rapid response force, one that is critical to preventing tensions from escalating into a larger conflict. 
As the entire Joint Force prepares to take on an increasingly complex security situation shaped by Russia's global aspirations, the Marine Corps will have an essential role to play in maintaining stability on NATO's northern flank.

\section{Notes}

1. "Trident Juncture 18," NATO, last updated 31 October 2018.

2. U.S. European Command, "US Forces Ready for NATO Exercise Trident Juncture 18 ," press release, 22 October 2018.

3. James N. Mattis, Summary of the 2018 National Defense Strategy of the United States of America: Sharpening the American Military's Competitive Edge (Washington, DC: Department of Defense, 2018), 2.

4. Although the terms are not entirely interchangeable, both new generation warfare and hybrid warfare refer to Russia's use of information operations, deception, political subversion, proxy agents, and cyberwarfare to achieve its foreign policy objectives, notably in Ukraine and Syria. See Joseph V. Micallef, "Op-Ed: The Roots, Tactics and Consequences of New Generation Warfare," Military.com, 2 August 2018; and Russian New Generation Warfare Handbook (Fort Meade, MD: Asymmetric Warfare Group, 2016).

5. European Deterrence Initiative (Washington, DC: Department of Defense, 2018); and U.S. European Command, "FY 2020 European Deterrence Initiative (EDI) Funding Request," press release, 12 March 2019.

6. Hearing on the Posture of the United States Marine Corps (24 April 2018) (statement of Gen Robert B. Neller, Commandant, U.S. Marine Corps), 2.

7. Gen Neller has discussed this extensively. See, for example, his comments before the U.S. Senate Appropriations Committee in Hearing on the Posture of the United States Marine Corps.

8. Mitchell Yates, "How Putin Made Russia's Military into a Modern, Lethal Fighting Force," The Buzz (blog), National Interest, 25 February 2016.

9. Jonathan Masters, "Russia, Trump, and the 2016 U.S. Election," Council on Foreign Relations, 26 February 2018.

10. Although it is difficult to give the exact geographical boundaries for the High North, the term is often used as a synonym for the Arctic, and more widely for the countries that have territory within the Arctic region. The Norwegian government specifically uses High North to refer to the parts of the country that lie north of the Arctic Circle. See, for example, "The High North," Permanent Delegation of Norway to NATO, accessed 10 August 2019. See also NATO Secretary General Jens Stoltenberg's use of the phrase as a synonym for the Arctic region in "Conversation with NATO Secretary General Jens Stoltenberg at the Brussels Forum," NATO, transcript, 27 June 2019.

11. Hugh K. O'Donnell, "Northern Flank Maritime Offensive," U.S. Naval Institute Proceedings (September 1985); and Orlo K. Steele and Michael I. Moffett, U.S. Marine Corps Mountain Warfare Training Center, 1951-2001 (Washington, DC: History Division, Headquarters Marine Corps, 2011), 97.

12. John Lund, Don't Rock the Boat: Reinforcing Norway in Crisis and War (Santa Monica, CA: Rand, 1989), 21.

13. The Significance of Norway, Special Intelligence Report 2-65 (Norfolk, VA: Headquarters, Fleet Marine Forces, Atlantic 1965), 5; and Steele and Moffett, U.S. Marine Corps Mountain Warfare Training Center, 1951-2001, 98.

14. Quoted in Col Joseph H. Alexander, "The Role of U.S. Marines in the Defense of North Norway," U.S. Naval Institute Proceedings (May 1984).

15. Memorandum of Understanding (MOU) Governing Prestockage and Reinforcement of Norway, Government of the United States of America and Government of the Kingdom of Norway, 16 February 1981. For a more comprehensive discussion of the MOU, see also George R. Hoffmann Jr., "Reinforcing North Norway: The Marine Amphibious Brigade's Contribution" (research paper, Naval War College, 1984).

16. Lund, Don't Rock the Boat, 62. 
17. Steele and Moffett, U.S. Marine Corps Mountain Warfare Training Center, 1951-2001, $107-23$.

18. Alexander, "The Role of U.S. Marines in the Defense of North Norway."

19. "History of the U.S. Marine Corps Forces Europe and Africa," Marine Forces Europe and Africa, accessed 26 February 2019.

20. "26th MEU History," 26th Marine Expeditionary Unit, accessed 26 February 2019.

21. AF stands for Africa, to indicate that it is also included within the command's AOR. See "History of the U.S. Marine Corps Forces Europe and Africa."

22. SPMAGTF-CR-AF is based in Europe but is exclusively focused on preparing for possible crises in Africa. Shawn Snow, "No More Marine Rotations to the Black Sea. The Corps Is Focusing Here Instead," Marine Corps Times, 29 November 2018.

23. Maj Leslie N. Janzen, "Revisiting the NALMEB," Marine Corps Gazette 81, no. 8 (1997): 35. See also Study to Assess Continued Maritime Prepositioning Ships Maintenance at Blount Island and to Conduct a Review of Marine Corps Ashore Prepositioning (Washington, DC: Headquarters Marine Corps, 1997).

24. Memorandum of Understanding (MOU) Governing Prestockage and Reinforcement of Norway.

25. Prepositioning Programs Handbook, 3d ed. (Washington, DC: Headquarters Marine Corps, 2015), 25.

26. Ministry of Defense of Norway, "Increased Allied Training and Exercises," press release, 15 August 2018.

27. John Vandiver, "US Marine Force in Norway to Eye Arctic and Beyond," Stars and Stripes, 6 January 2017; and Julian E. Barnes and Ellen Emmerentze Jervell, "Amid Trump’s NATO Blasts, U.S. Marines' Norway Mission Goes On,” Wall Street Journal, 16 January 2017.

28. "Secretary of Defense James N. Mattis' Meeting with Frank Bakke-Jensen, Norway Minister of Defense," Department of Defense, transcript, 14 July 2018.

29. Summary of the 2018 National Defense Strategy of the United States of America, 2.

30. Ivana Kottasová, "Russian Military Spending Drops for First Time in 20 Years," CNN, 2 May 2018.

31. Embassy of the Russian Federation to the United Kingdom of Great Britain and Northern Ireland, "The Military Doctrine of the Russian Federation," press release, 29 June 2015; and President of the Russian Federation, O Strategii natsional'noi bezopastnosti rossiiskoi federatsii [On the National Security Strategy of the Russian Federation], 31 December 2015.

32. James G. Foggo and Alarik Fritz, "X. NATO and the Challenge in the North Atlantic and the Arctic," Whitehall Papers 93, no. 1 (2018): 124, https://doi.org/10.1080/0268 1307.2018.1508970.

33. Russia Military Power: Building a Military to Support Great Power Aspirations (Washington, DC: Defense Intelligence Agency 2017), 67.

34. "Air Force and Air Defense Army for Russia's Arctic to be in Place 2015-General Staff," TASS, 29 December 2014.

35. Air Force Gen Tod D. Wolters took command of EUCOM and Supreme Headquarters Allied Powers Europe (SHAPE) in May 2019; and Hearing on the U.S. European Command in Review of the Defense Authorization Request for Fiscal Year 2019 (8 March 2018) (statement of Gen Curtis M. Scaparrotti, commander, EUCOM and SACEUR), hereafter Scaparrotti EUCOM statement.

36. Michael R. Pompeo, "Looking North: Sharpening America’s Arctic Focus," State Department, transcript, 6 May 2019.

37. Focus 2017: The Norwegian Intelligence Service's Assessment of Current Security Challenges (Oslo, Norway: Norwegian Intelligence Service, 2017), 14.

38. Focus 2017, 14.

39. Interview with Norwegian diplomats, 29 January 2019, Washington, DC.

40. BGen Lars S. Lervik, email interview with author, 6 February 2019, hereafter Lervik 
interview. See also Setting the Course for Norwegian Foreign and Security Policy, Meld. St. 36 (2016-2017) (Oslo, Norway: Ministry of Foreign Affairs, 2017).

41. Interview with Norwegian diplomats.

42. Lervik interview.

43. For a more comprehensive assessment of Norwegian military capabilities, see "Western Europe," Jane's Sentinel Security Assessment, 2011.

44. Interview with Norwegian diplomats.

45. Scaparrotti EUCOM statement.

46. Scaparrotti EUCOM statement.

47. United States Senate Committee on Armed Services, 5 March 2019 (statement of Gen Curtis M. Scaparrotti, commander, EUCOM and NATO SACEUR).

48. Senate Armed Services Committee Advance Policy Questions for General Tod D. Wolters, USAF Nominee for Appointment to the Position of Commander, United States European Command and Supreme Allied Commander, Europe, 2 April 2019, hereafter Wolters appointment statement.

49. President Donald Trump has indicated that some DOD projects, including perhaps those funded by EDI, might be delayed or canceled to fund construction of a border wall. See, for example, Charlie Savage, "Trump to Tap Other Military Money for Wall before Emergency Funds," New York Times, 19 February 2019.

50. European Deterrence Initiative.

51. Ian T. Brown, A New Conception of War: John Boyd, the U.S. Marines, and Maneuver Warfare (Quantico, VA: Marine Corps University Press, 2018), xxvii.

52. President Trump's priorities are to reduce U.S. troop presence in both Syria and Afghanistan. See, for example, "After Syria, Trump Planning 'Troop Withdrawal from Afghanistan'," Al Jazeera, 21 December 2018.

53. "Atlantic Resolve," U.S. Army Europe, accessed 20 February 2019.

54. Robert B. Neller, "Discussion with General Robert B. Neller, Commandant of the U.S. Marine Corps" (speech, Center for Strategic and International Studies, Washington, DC, 25 January 2018).

55. Cold Region Operations, Field Manual (FM) 31-70 and FM 31-71 (Washington, DC: Headquarters, Department of the Army, 2011), iv.

56. Marine Corps Task List (MCTL-2.0) (Quantico, VA: Headquarters Marine Corps, 2017).

57. For Marine Corps doctrine, see Marine Corps Operations, Marine Corps Doctrinal Publication 1-0 (Washington, DC: Headquarters Marine Corps, 2017).

58. For more discussion about how Russia specifically operates and how the U.S. military can effectively respond, see The U.S. Army in Multi-Domain Operations, 2028, TRADOC Pamphlet 525-3-1 (Fort Eustis, VA: U.S. Army Training and Doctrine Command, 2018).

59. Summary of the 2018 National Defense Strategy of the United States of America, 7.

60. Wolters appointment statement, 8-9.

61. Pompeo, "Looking North."

62. Interview with Norwegian diplomats.

63. Interview with Norwegian diplomats.

64. Lervik interview.

65. "Defense of Iceland: Agreement between the United States and the Republic of Iceland," in American Foreign Policy, 1950-1955, vols. I and II, Basic Documents, Department of State Publication 6446, General Foreign Policy Series 117 (Washington, DC: U.S. Government Printing Office, 1957); and "U.S. Relations with Iceland," U.S. Department of State, Bureau of European and Eurasian Affairs, 22 October 2018.

66. Teri Schultz, "NATO and Washington Worry about Russian Subs in the High North," Deutsche Welle, 26 April 2018.

67. LCpl Margaret Gale, "24th MEU Capabilities on Display in Iceland," U.S. Marine Corps (official website), 19 October 2018.

68. For example, the 2d MEB took part in the Norwegian exercise Cold Response in 2016; 
it was the first time the Marine Corps had sent more than a battalion-size element to the exercise. Matthew L. Schehl, "Marines Hit the Arctic for Largest Winter Exercise Since the Cold War," Marine Corps Times, 2 March 2016.

69. MajGen Stephen M. Neary (II MEF deputy commander), phone interview with author, 1 February 2019, hereafter Neary interview.

70. Lervik interview.

71. Neary interview.

72. Interview with Norwegian diplomats.

73. Neary interview.

74. Ministry of Defence of the United Kingdom, "Defence Secretary Announces First Deployment for New Sub-Hunter Aircraft," press release, 18 February 2019.

75. U.S. Department of Defense, "Remarks by Acting Secretary Esper in a Press Conference at NATO HQ, Brussels, Belgium," Department of Defense, transcript, 27 June 2019.

76. Scaparrotti EUCOM statement.

77. Neary interview. 


\title{
A Case for Sino-American Cooperation Against Climate Change
}

\author{
Kevin Johnston
}

\begin{abstract}
The United States and China's continued aggressive actions in the South China Sea threaten to spark a war between two of the world's largest military and economic powers. Meanwhile, Climate Change continues to harm people and infrastructure in both countries. To overcome the threat posed by Climate Change, the United States and China must work together toward a mutually beneficial goal.
\end{abstract}

Keywords: climate change, global warming, Sino-American cooperation, power projection, Belt and Road Initiative

\section{In Medias Res}

A

n opportunity exists to improve relations between the United States and China by jointly confronting Climate Change. ${ }^{1}$ It is a relationship in great need of repair. Military tensions in the South China Sea, conjoined with an ongoing trade war, have strained Sino-American relations. ${ }^{2}$ Each country is suspicious of the other based on perceived provocations. The United States sought five members of the People's Liberation Army (PLA) in 2014, alleging the men had breached the federal government's Office of Personnel Management. ${ }^{3}$ China's land-reclamation project in the South China Sea has

Kevin Johnston is an Army veteran who currently works as a DOD contractor. From 2011 to 2015, he served as a logistics officer in the 4th Sustainment Brigade. He completed his bachelor's degree from Dickinson College, Carlisle, PA, in 2011 and his master's degree from Saint Mary's University, San Antonio, TX, in 2015. He would like to thank the following individuals who lent their time to help him edit this article: LtCol Jeannette G. Haynie, PhD; Maj Jason Bogden, PhD; 2dLt Amelia Snyder; and Daniel Gagliano, master's student at Johns Hopkins University School of Advanced International Studies. 
transformed uninhabited coral reefs into air and naval bases, greatly increasing China's military presence in the area. ${ }^{4}$ In response, the United States conducted military exercises in the South China Sea throughout 2018. ${ }^{5}$ Both countries continue to increase their military footprint in the area, either unilaterally or with allied forces. ${ }^{6}$ These growing tensions remain unabated, making warfare between the two countries more likely in the near future. At the same time, Climate Change threatens the people and infrastructure of both countries. Therefore, working together to overcome Climate Change is the best opportunity for the United States and China to avoid military conflict.

As China expands its economy and strengthens its military, it looks to break further onto the world stage. Opposing this growth is the United States, the sole remaining superpower after the end of the Cold War. Both countries have conflicting interests, creating a situation ripe for military conflict. But the Sino-American relationship is filled with examples of pragmatic diplomacy.

The United States and China have a history of strong diplomatic cooperation and of overcoming difficult obstacles to reach peaceful solutions. Rapprochement with China, led by President Richard M. Nixon, began during the Cold War, after years of American efforts to "disrupt, destabilize, and weaken China's communist government." The two countries normalized relations in 1979, reaching an understanding wherein the United States ceded that there was only one China, and wherein China recognized that the United States could continue to trade with Taiwan. ${ }^{8}$ In 2014, the United States and China released a joint announcement on Climate Change, and both pledged to increase their efforts to reduce emissions. ${ }^{9}$ In each agreement, both countries put aside their ideological differences to accomplish a mutually beneficial goal.

Climate Change threatens the future of both the United States and China. The National Aeronautics and Space Administration (NASA) defines Climate Change as

a broad range of global phenomena created predominantly by burning fossil fuels, which add heat-trapping gases to Earth's atmosphere. These phenomena include the increased temperature trends described by global warming, but also encompass changes such as sea level rise; ice mass loss in Greenland, Antarctica, the Arctic and mountain glaciers worldwide; shifts in flower/plant blooming; and extreme weather events. ${ }^{10}$

NASA further states that global warming is "due to the increase in fossil fuel emissions since the Industrial Revolution." ${ }^{11}$ Disruptive events such as sea level rise, extreme weather events, and shifts in plants blooming threaten the goals of both nations.

China wants to thrive economically, meaning it will need healthy citizens, 
and the United States wants to protect itself from foreign military threats. These are both Climate Change-related issues. Currently, the effects of emissions kill thousands of Chinese every year and threaten the security interests of the United States around the globe. Military installations, such as Diego Garcia, are threatened by a rise in sea level. ${ }^{12}$ In the future, Climate Change could cause droughts and famines in China, while harming the security of the United States by degrading operational readiness and by destroying equipment and military installations. Overcoming Climate Change together will strain the ambitions and resources of each country, but it is ultimately imperative for the survival of billions of people around the world.

\section{Rising Dragon versus Wounded Eagle}

The United States and China support the most powerful economies on Earth, and their militaries both possess atomic weapons. Following the end of the Cold War, the United States emerged as a lone global superpower with a powerful military and a robust economy. Ongoing military conflicts, rising debts, and the Great Recession negatively impacted the United States' ability to project power. While the United States floundered, China surged forward and surpassed the United States in 20 economic indicators, including steel production and manufacturing. ${ }^{13}$ In doing so, China's emissions surpassed those of the United States, due to its heavy reliance on coal for energy. ${ }^{14}$ This newfound economic prowess allows China to act more assertively around the world, through the Belt and Road Initiative and increased military activity in the South China Sea.

In 2013, China announced the Belt and Road Initiative, designed to link Africa and Europe to China. Disguised as economic expansion, the initiative allowed China to accomplish military objectives without using military force. Building more than a dozen new ports as far away as Djibouti, China plans to extend its economic prowess far beyond its borders. ${ }^{15}$ China coerces other countries by taking control of their foreign debt and utilizes debt-trap diplomacy to achieve strategic goals. Notable victories include taking land from Tajikistan and leasing a port from Sri Lanka for 99 years. ${ }^{16}$ These nonmilitary conquests allowed China to greatly increase its sphere of influence.

At roughly the same time, China initiated a campaign to control the South China Sea when it claimed islands belonging to several other nations. ${ }^{17}$ After launching an aircraft carrier and surface warfare ships, China created islands out of shoals and reefs to use as airstrips. This military buildup strengthens China's offensive capabilities against the U.S. military. ${ }^{18}$ It also creates a situation where both militaries will be consistently within striking distance of one another.

The United States has a strong military presence in the South China Sea. With a budget of $\$ 610$ billion, the U.S. military spent more in 2018 than the next seven countries, surpassing even China's budget. ${ }^{19}$ The U.S. Navy has 10 
Nimitz-class aircraft carriers, which dwarf the next largest class of aircraft carriers. ${ }^{20}$ With bases in Japan and South Korea, the U.S. military poses a strong threat to any Chinese aggression. ${ }^{21}$ Moreover, the United States is formally allied to its NATO counterparts, which includes two other countries with atomic weapons. Though they lack a presence in the region, NATO is obligated to respond in full if a member nation is attacked. This is a formidable defense against any Chinese aggression in the South China Sea. If the Chinese attack anywhere there are American forces or allies, victory for the People's Republic of China (PRC) is uncertain at best.

The conditions seem ripe for a military conflict. China, the rising power flush with newfound economic might and an increasingly powerful military, against the ruling world power, the United States. Such a conflict would undoubtedly be disastrous and may even be apocalyptic, much like the threat of a nuclear war between the United States and the Soviet Union. In a message to President Harry S. Truman, Albert Einstein wrote, "I know not with what weapons World War III will be fought, but World War IV will be fought with sticks and stones." 22

\section{The Case for Cooperation: MAD-ness Does Not Reign}

Mutually assured destruction (MAD) is a powerful incentive to put aside differences in the interests of peace. As during the Cold War and the Soviet-Japanese tensions, both the United States and China already possessed nuclear weapons. The Americans' arsenal outnumbers the Chinese, with 6,550 warheads to China's $280 .{ }^{23}$ Both countries militaries' have atomic weapons that can be launched from land bases, naval ships, or aircraft in what is known as a nuclear triad. ${ }^{24}$ In short, there is no way either country would escape considerable damage should they make use of their nuclear arsenals.

Counting on mutually assured destruction to prevent armed conflict is risky at best. During the Cold War, the Soviet Union and United States both nearly came close to launching their weapons based on perceived threats or fraudulent computer readings. To ensure that the United States and China remain at peace, they should find a mutual adversary, such as Climate Change, and work together to destroy that adversary, thereby saving themselves and each other.

\section{Rising Seas as a Rising Power}

Both China and the United States currently suffer from, and will continue to suffer from, the effects of Climate Change. This threat goes underrecognized in political circles because it is not a hostile military force or traditional adversary. The United States and China must recognize that Climate Change poses an existential threat to them both and that an alliance is the only way to overcome 
both challenges simultaneously. They can do so by considering Climate Change a rising hostile power.

Consider the following: a new global power emerges and threatens key interests of the United States and China. It attacks America's military installations around the world, crippling the Florida Air National Guard, and forces the Marines Corps Mountain Warfare Training Center to stop training, reducing the military readiness of those units. In China, this new power threatens both food and water security and could overrun dozens of seaborne cities that are home to millions of people with flooding. Attacks by this power kill people every year in increasing numbers and will continue this pattern until the status quo changes. ${ }^{25}$ This power has no visible leader or communications system. It does not require funding, recruiting, or retention. This new power, Climate Change, is combated by nearly every nation on Earth but is not challenged adequately by the world's strongest powers-the United States and China. A coalition of interrelated issues-pollution, overpopulation, mismanagement of resources, global trade, food security, and water scarcity—continue to strengthen this new power, making it deadlier over time. The two nations most responsible for the rise of this new threat, and in the best position to combat it, waste their time in a zero-sum game over dominance of the South China Sea. While they bicker, this new power continues to attack both with prejudice.

\section{Clipped Wings:}

\section{The Effects of Climate Change on the U.S. Military}

Climate Change has the potential to reduce the effectiveness of the U.S. military through the destruction of military installations, the degradation of unit effectiveness, and damage to essential warfighting equipment. According to Chairman of the Joint Chiefs of Staff General Dunford, "When I look at climate change, it's in the category of sources of conflict around the world and things we'd have to respond to. So it can be great devastation requiring humanitarian assistance-disaster relief—which the U.S. military certainly conducts routinely." ${ }^{26}$ Despite this assessment, the American government fails to recognize the threat posed by Climate Change. The United States recently promised to withdraw from the Paris Agreement on 4 November 2020, and President Donald J. Trump has repeatedly expressed skepticism regarding the effects of Climate Change. ${ }^{27}$

The lack of military spending to combat Climate Change is at odds with how much money the United States spends to counter other threats. When terrorists attacked the United States on 11 September 2001, America spent more than a trillion dollars in military actions abroad to prevent another such attack from 2011 to the present. ${ }^{28}$ In the hopes of stopping the proliferation of weapons of mass destruction, which now has a low probability, the United 
States spent billions of dollars to fund arms control treaties. However, to counter threats based on Climate Change, which are far more certain, the United States spends less money. ${ }^{29}$ This is due to the refusal of policy makers to act on the threat posed by Climate Change, despite the effects it could have on American security and defense.

As with a traditional enemy state, Climate Change uses both direct and indirect attacks against American forces and interests around the world. By degrading American military installations and damaging equipment, Climate Change reduces the effectiveness and speed with which the United States can respond to an international crisis. By destroying the environment of fragile nations and disrupting their economies, Climate Change acts as a force multiplier for nefarious groups, helping them swell their ranks and cause more destruction than ordinarily possible. ${ }^{30}$ These attacks, if they came from a rival nation, would generate an immediate and intense response. But they currently provoke a small, inadequate response.

A 2019 Department of Defense study of 79 military bases shows the damage already being done to American infrastructure by Climate Change. The report found that the majority of bases are already suffering from one of several climate attacks, such as recurrent flooding, drought, desertification, wildfires, or thawing permafrost. ${ }^{31}$ According to the report, "About two-thirds of the 79 installations addressed in this report are vulnerable to current or future recurrent flooding and more than one-half are vulnerable to current or future drought. About one-half are susceptible to wildfires." 32 Moreover, the threats are only going to escalate in strength and frequency unless solutions to Climate Change are reached. Bases that are not presently vulnerable to attack from Climate Change are likely to be within 20 years. Within that time, five more bases could by attacked by drought, seven more by flooding, and seven more by wildfire. ${ }^{33}$ Without intervention, the costs of Climate Change attacks will only continue to rise.

Climate Change has already cost the U.S. Department of Defense billions of dollars. In 2018, Hurricane Michael damaged Tyndall Air Force Base in Panama City, Florida, so badly it will cost $\$ 5$ billion to repair. ${ }^{34}$ Similarly, Marine Corps Base Camp Lejeune in Jacksonville, North Carolina, suffered \$3.6 billion worth of damage when Hurricane Florence struck. ${ }^{35}$ In total, 14 climate events cost the United States more than $\$ 1$ billion to repair in 2018 alone. ${ }^{36}$ The financial toll is just one aspect of damage caused by Climate Change.

Operations have been widely affected at bases attacked by Climate Change. The Department of Defense cited four examples where tests, training, launches, or essential activities have been disrupted in the United States:

Wildfires in the western United States affecting Vandenberg Air Force 
Base, California, and operations at the Western Range and Point Mugu Sea Range. Hurricanes resulting in damage to infrastructure and delays in training, testing programs, and space launches at Tyndall Air Force Base, at the Atlantic Undersea Test and Evaluation Center in the Bahamas, and at the Eastern Range in Cape Canaveral, Florida. Permafrost thawing at the U.S. Army's Cold Regions Test Center, Fort Greely, Alaska, impacting cold weather testing activities. Rising seawater washover and contamination of freshwater on atoll installations. ${ }^{37}$

Climate Change threatens American military bases around the world. Bases located near water are particularly vulnerable to rising sea levels. Diego Garcia, an Indian Ocean atoll, is 6.5 feet above sea level, meaning that it is vulnerable to storm surges and a rise in sea level. ${ }^{38}$ Rising sea levels threaten Naval Base Guam, the Ronald Reagan Ballistic Missile Defense Test Site located on Kwajalein Atoll, and the American Naval Support Activity Bahrain. ${ }^{39}$ These bases are used as logistics hubs, missile-testing sites, and to secure American interests in the Pacific and the Strait of Hormuz. Without these bases, American security around the world is threatened.

The threats continue to multiply as time passes and will affect an increasing amount of American security interests. Political instability creates incubator conditions for terrorist organizations around the world. In the United States Africa Command (USAFRICOM) area of responsibility, mission execution is affected by the rainy season flooding and drought/desertification. ${ }^{40}$ Instability in the U.S. Indo-Pacific Command (INDOPACOM) can be attributed to flooding and tsunamis in Indonesia. ${ }^{41}$ In Africa and the India/Pacific region, instability has historically led to increased recruitment for groups such as Boko Haram, as well as other terrorist groups hostile to the United States. ${ }^{42}$ The $\mathrm{Al}$ Udeid Air Base in Qatar may become so warm by the year 2100 that humans will not be able to live outside. ${ }^{43}$ Climate Change exacerbates already volatile situations, threatening American security around the world.

Intelligence, surveillance, and reconnaissance and personnel recovery/casualty evacuation and logistics flights from Europe to the African continent are affected by weather conditions over the Mediterranean Sea. When the conditions are poor, there is an increase in no-go flight days. ${ }^{44}$ This impacts the military's ability to gather crucial intelligence or resupply bases and could even affect attempts to rescue wounded or lost servicemembers. ${ }^{45}$

\section{Renewed Hope through Renewable Energy}

Recognizing the problem, the American military is taking steps to mitigate Climate Change through direct action. The energy performance master plan lays 
out three elements designed to reduce emissions: expand supply, reduce demand, and adapt future forces and technology. ${ }^{46}$ Each Service is responsible for reducing emissions based on a 2003 baseline of energy consumption.

By 2015, the U.S. Army reduced 18 percent of its emissions and created or bought 9.5 percent of its electricity from renewable resources. Additionally, the Army Net Zero Initiative, created in 2010, aims to provide "greater water and energy security and increasing operational flexibility." ${ }^{37}$ Fort Hunter Liggett in California installed three one-megawatt photovoltaic systems and is expected to install more in the future. Compared to 2011 energy usage, net zero installations reduced energy use intensity by 13 percent. ${ }^{48}$

From 2003 to 2015, the U.S. Air Force reduced its energy facility consumption by nearly 25 percent. This stemmed from the 311 energy projects installed or under construction. Nevada's Nellis Air Force Base alone is capable of powering itself on sunny days through two large photovoltaic panels. ${ }^{49}$

The Navy and Marines reduced energy intensity by 22 percent from 2003 to 2015 and have a goal to reduce energy intensity by a further 50 percent by $2020 .{ }^{50}$ Additionally, the Navy created a geothermal plant at China Lake, California, and created a waste-to-energy plant in Norfolk, Virginia. The Navy is committed to using biofuels and the John C. Stennis Carrier Strike Group deployed with renewable fuels. ${ }^{51}$

But military changes are not enough to solve the overall problem. After Syria and Nicaragua joined the Paris Agreement, the United States became the only country on Earth opposed to the agreement. ${ }^{52}$ As current trends continue and intensify, America's military capabilities will become crippled as its threats multiply.

\section{Dehydrated Dragon: Water Crisis in China}

China's rise as an economic and military powerhouse can be described as meteoric. Currently, it is the only country in the world that is seen as a potential peer of the United States, and it plans to expand its diplomatic might for decades to come. But while China risks military conflict abroad, its greater challenge lies with limited resources needed to sustain a booming population. Due to a loss of freshwater coupled with rising seas along its densely populated coasts, China could lose millions of people and see its economy greatly impacted by an inability to combat Climate Change.

Despite being home to 1.3 billion people, China only possesses 6 percent of the world's overall water supply. This causes conservation problems that will become more severe in the future. The rivers China depends on for its water supply will peak between 2030 and 2050, as glaciers in the north melt. In northern China, 70 percent of the villages already suffer from a lack of water, 
where there are few financial incentives to conserve along with infrastructural deficiencies and pollution depleting the supply continuously. ${ }^{53} \mathrm{~A}$ lack of water is a singular problem but threatens to create a host of powerful issues that would threaten China's growth and development in the decades to come, including food shortages and the spread of disease.

Food security is defined by the Chinese government as being able to produce 95 percent of their grain domestically. This becomes more difficult in light of China's rising population, expected to reach 1.6 billion by 2030, which will increase demand for food as more of the population reaches economic prosperity and consumes more meat. ${ }^{54}$ Grain that could be fed to people instead gets diverted to feed animals. These growth factors will inhibit the goal of 95 percent grain production.

As rivers dry up, China could see the failure of their irrigation farms, responsible for 75 percent of their grain production. Droughts and floods, which cost China 50 million tons of food between 2001 and 2002, will become more common. ${ }^{55}$ China's inability to feed itself will lead to it buying more from other countries, thereby decreasing capital needed to advance its diplomatic agenda.

\section{Fighting Fire with Regulations: The 2016 Five-Year Plan}

China adopted radical plans to counter the effects of Climate Change, with plans designed to reduce energy emissions throughout the country and lessen pollution in major cities. In keeping with its plans to reach peak energy by 2030, China was already the world's largest investor in renewable energy in 2012 and pledged billions of dollars to the developing world to help combat Climate Change starting in 2015. ${ }^{56}$ Its next step, The 13th Five-Year Plan (FYP), is "the most environmentally-focused FYP to date." 57 Ten of the 2016 plan's 25 goals focus on environmental development in an effort to undue damage sustained by previous economic growth. To improve air quality, land quality, and water quality, China is taking what the U.S.-China Economic and Security Review Commission has divided into four efforts: expand nationwide monitoring and evaluation metrics; set energy and carbon dioxide emissions intensity reductions; improve air, soil, and water quality; and support domestic green industries. ${ }^{58}$

The Chinese government is expanding the environmental monitors across the country. The last FYP focused on monitoring air quality, looking for carbon monoxide, ozone, and nitrogen dioxide, among other substances. The new FYP monitors soil and water levels, including in streams and lakes. ${ }^{59}$ Recognizing the dwindling supply of water, the FYP's stated goals include:

Priority protection of good-quality water bodies;

Establishing holistic strategies to tackle groundwater pollution; 
Strongly improving polluted urban water bodies; and

Improving water quality of river mouth and nearshore areas. ${ }^{60}$

By 2020, the Chinese government wants 70 percent of nationwide groundwater to reach grade III. ${ }^{61}$ To hold local leaders more responsible, goals are implemented directly from the central government. ${ }^{62}$ These national checks will help the government achieve its other objectives.

The FYP sets a nationwide energy cap in an attempt to reduce emissions. An essential part of this action will include increasing renewable energy from 12 to 15 percent by investing in solar, wind, and geothermal energy. ${ }^{63}$ To reduce emissions, China suspended more than 100 coal projects and closed heavy industries producing excess capacity. ${ }^{64}$ Reducing emissions will allow the government an opportunity to rejuvenate its air, soil, and water.

The goals regarding air, soil, and water pollution illustrate the damage done in earlier generations. One of the requirements for air is for cities to have good air quality 80 percent of the time by 2020, a tacit admission that Chinese citizens breathe poor air currently. By raising the price of gasoline, China hopes to pay for facility upgrades and increase the quality standard of gasoline. ${ }^{65}$ The decontamination of soil is harder to address, as the government does not fully understand the extent of the problem. With an overarching goal to decontaminate 90 percent of polluted farmland by 2020 and another 5 percent by 2025 , China hopes to be able to use 666,000 hectares for farmland and 5,000 square miles as forest and grassland by $2020 .{ }^{66}$ Water quality and overuse present the greatest challenge for China. The previous FYP water consumption cap was exceeded by 18 billion cubic meters. It also called for a reduction in pollutants that missed its goal. ${ }^{67}$ Without fast improvements to natural resources, especially water quality, China will soon find its foreign policy compromised by an inability to meet domestic requirements.

To meet increased energy needs, China will continue to support green energy vehicles and energy-saving technologies. From the last FYP, China became a leader in renewable energy in less than a decade and became the leading producer of solar panels in $2015 .{ }^{68}$ This trend will be difficult to continue as the market struggles with overcapacity ${ }^{69}$ China is also trying to make its economy more environmentally friendly by concentrating investments on green companies and investing in pollution-mitigation efforts. ${ }^{70}$

China's past growth degraded its soil, air, and water. Today, China burns half the world's coal, creating an enormous carbon footprint. ${ }^{71}$ Without substantial reform, China will soon be unable to provide its people with clean water, food, and air. These failures in governance will doubtlessly hinder their foreign policy and could stagnate its economy and military at a time China seeks improvement over its peers. 


\section{Soaring Together: China and the United States Cooperate to Defeat Climate Change}

The greatest threat to the United States and China is Climate Change. Instead of trying to defeat each other, they must work together to defeat a mutual enemy. The blueprint for a military counteroffensive against Climate Change was created in 1948. That year, the Marshall Plan (officially the European Recovery Program) helped European nations recover from the Second World War. The $\$ 13$ billion spent created economic growth and helped create the European Union. ${ }^{72}$ The Marshall Plan is credited with saving Europe from financial ruin and deterring Soviet domination of the continent. A similar plan could help save the world from the threat of Climate Change.

When the Marshall Plan was initiated in 1948, it built on previous efforts made directly after the war, such as the military assistance to Greece and Turkey and humanitarian assistance conducted by the United Nations. ${ }^{73}$ To create a new Marshall Plan, the United States and China would need to draw on previously existing treaties, such as the Trans-Pacific Strategic Economic Partnership Agreement (2005) and the Asia-Pacific Economic Cooperation (1989). The aim of this Climate Change plan would be to stop or reduce Climate Change by providing funds to countries who applied for aid to develop renewable energy, protect forests, and reduce greenhouse gases. ${ }^{74}$

An essential aspect of a new Marshall Plan will be a reduction of military tensions between the United States and China. Both countries currently spend a large part of their annual budgets on military expenditures in the South China Sea. This money could be better spent combating Climate Change by retrofitting bases with renewable energy, investing in alternatives to fossil fuels, or repairing damage done to coral reefs or forests. Joint projects such as cleaning the Great Pacific Garbage Patch, working to prevent further plastic pollution, and reducing the importation of recyclables from the First World, can lay the groundwork for more cooperation, which will hopefully lessen tensions.

The United States and China will fund the new Climate Change Marshall Plan. Through the Copenhagen Accord (2009) and the Paris Agreement, nations around the world agreed to reduce Climate Change together. Member states have already made significant steps. The United Kingdom reduced its emissions by nearly 4 percent in 2017 by reducing coal use 20 percent. Mexico's emissions dropped 4 percent in the same time frame. ${ }^{75}$ In 2014-15, 21 countries, including the United States, grew their economies while decreasing their emissions, shattering the myth that economic growth entailed greater carbon emissions. ${ }^{76}$ With the help of China and the United States, countries around the world can lower emissions faster and more efficiently than if they were doing it on their own.

This plan would have immediate and long-term benefits for both countries. 
A world with reduced emissions would mean fewer natural disasters hurting American military facilities and personnel. It would also prevent the glaciers that supply China's rivers from peaking and cutting the flow of clean water for crop development. Working together would enable China and the United States to view each other as allies in a sustained fight. If this sounds far-fetched, recall that prior to the First World War, Britain and United States fought two wars even though the British considered intervening in the Civil War on the side of the Confederacy. Now the two nations are close allies, celebrating more than a century of a so-called special relationship.

Similarly, the United States and China fought two proxy wars against one another in Korea and Vietnam. Much as allying to win the First and Second World Wars brought the United States and United Kingdom together, an alliance against Climate Change can bring the United States and China together. In trying to stop Climate Change, the United States and China can also try to prevent a military conflict certain to cause immense damage to each side.

There are numerous pitfalls that must be overcome for the United States and China to work together effectively. A significant portion of the American electorate now understands the threat posed by Climate Change, but only 28 percent would agree to pay an extra $\$ 10$ a month to combat that threat. ${ }^{77} \mathrm{Chi}-$ na's growth is tied to its use of fossil fuels and stunting this growth for the sake of Climate Change will be difficult to accept. The United States is accustomed to being the lone superpower in the world and will resent losing its status. In the pursuit of peace, concessions on both sides must be made.

If China and the United States do not act quickly to prevent the worst effects of Climate Change, the future for both nations seems very bleak. Should the two countries decide against peace, the ensuing war has the potential to become the first mutual exchange of nuclear weapons. Should they fail to create an alliance to prevent the worst effects of Climate Change, the ensuing results will resemble a world war with respect to economic damage and the number of people killed. Overcoming shared myopia and greed to establish a lasting peace that sustains the future is the only safe path forward.

\section{Notes}

1. For the purposes of this article, the author purposefully capitalized Climate Change so that readers view it as a peer of a nation-state.

2. "U.S. Relations with China, 1949-2019," Council on Foreign Relations, accessed 16 June 2019.

3. "U.S. Relations with China, 1949-2019."

4. "China to Expand Land Reclamation Activities in South China Sea, Say Experts," Strait Times, 6 February 2018; and Asia Maritime Transparency Initiative supported by the Center for Strategic and International Studies.

5. "Territorial Disputes in the South China Sea," Global Conflict Tracker, Council on Foreign Relations, last updated 17 July 2019.

6. "Territorial Disputes in the South China Sea." 
7. "U.S.-China Relations Since 1949," Asia For Educators (Columbia University), accessed 24 July 2019.

8. Jim Mann, About Face: A History of America's Curious Relationship with China from Nixon to Clinton (New York: Random House, 1999).

9. White House, "U.S.-China Joint Announcement on Climate Change," press release, 11 November 2004.

10. "Overview: Weather, Global Warming and Climate Change," NASA, accessed 24 July 2019.

11. "Overview: Weather, Global Warming and Climate Change."

12. Esther Babson, "Interactive Map: The Vulnerability of America's Military Bases to Climate Change," American Security Project, 12 December 2017.

13. Graham Allison, "The Thucydides Trap: Are the U.S. and China Headed for War?," Atlantic, 24 September 2015.

14. "United States and China Advance Policies to Limit CO2 Emissions," U.S. Energy Information Administration, 18 November 2015.

15. Lily Kuo and Niko Kommenda, "What Is China's Belt and Road Initiative?," Guardian, 30 July 2018.

16. Kuo and Kommenda, "What Is China's Belt and Road Initiative?"

17. “Chinese Navy to Focus on 'Open Seas,' Paper Says," BBC, 26 May 2015.

18. See "Chinese Navy to Focus on 'Open Seas,' Paper Says"; and Asia Maritime Transparency Initiative.

19. "U.S. Defense Spending Compared to Other Countries," Peter G. Peterson Foundation, 3 May 2019.

20. Kyle Mizokami, "Here Is Every Aircraft Carrier in the World," Popular Mechanics, 25 January 2016.

21. "U.S. Military in the West Pacific," AnswersOn (blog), Thompson Reuters, 9 April 2012.

22. M. Alex Jones, “The Culture of Einstein,” NBC News, 18 April 2005.

23. "Nuclear Weapons: Who Has What at a Glance," Arms Control Association, last updated July 2019.

24. Anthony Capaccio, "Pentagon Sees China Seeking Nuclear Bomber to Compete with U.S.," Bloomberg, 15 January 2019.

25. "Climate Impacts on Coastlines: Rising Tides, Increasing Risks-Center for Climate and Life," Center for Climate and Life, Columbia University, 23 April 2018.

26. Report on Effects of a Changing Climate to the Department of Defense (Washington, DC: Department of Defense, 2019).

27. Helena Bottomiller Evich, "Agriculture Department Buries Studies Showing Dangers of Climate Change," Politico, 23 June 2019.

28. Francesco Femia et al., "The Inadequate US Response to a Major Security Threat: Climate Change," Bulletin of the Atomic Scientists, 20 July 2011.

29. Femia et al., "The Inadequate US Response to a Major Security Threat."

30. "Climate Change and Terrorist Groups-Explaining the Links," Climate Diplomacy, accessed 24 July 2019.

31. Report on Effects of a Changing Climate to the Department of Defense.

32. Report on Effects of a Changing Climate to the Department of Defense, 16.

33. Report on Effects of a Changing Climate to the Department of Defense.

34. Phil McKenna, "Hurricane Michael Cost This Military Base About $\$ 5$ Billion, Just One of 2018's Weather Disasters," Inside Climate News, 6 February 2019.

35. Mckenna, "Hurricane Michael Cost This Military Base About \$5 Billion."

36. Mckenna, "Hurricane Michael Cost This Military Base About \$5 Billion."

37. Report on Effects of a Changing Climate to the Department of Defense.

38. Babson, "Interactive Map."

39. Babson, "Interactive Map."

40. Report on Effects of a Changing Climate to the Department of Defense.

41. Report on Effects of a Changing Climate to the Department of Defense.

42. Report on Effects of a Changing Climate to the Department of Defense. 
43. Babson, "Interactive Map."

44. Report on Effects of a Changing Climate to the Department of Defense.

45. Report on Effects of a Changing Climate to the Department of Defense.

46. Sierra Hicks, Powering the Department of Defense: Initiatives to Increase Resiliency and Energy Security (Washington, DC: American Security Project, 2017).

47. Hicks, Powering the Department of Defense, 3.

48. Hicks, Powering the Department of Defense, 4.

49. Hicks, Powering the Department of Defense, 4.

50. Hicks, Powering the Department of Defense, 5.

51. Hicks, Powering the Department of Defense, 5.

52. For more on the Paris Agreement Under the United Nations Framework Convention on Climate Change (a.k.a. Paris Agreement), see Michelle Nichols, "Syria Formally Joins Paris Climate Agreement: U.N.," Reuters, 14 November 2017.

53. Peter Mackenzie and Marcus King, Climate Change in China: Socioeconomic and Security Implications (Arlington, VA: CNA, 2010).

54. Mackenzie and King, Climate Change in China.

55. Mackenzie and King, Climate Change in China.

56. Geoffrey Henderson et al., "5 Questions: What Does China’s New Five-Year Plan Mean for Climate Action?," World Resources Institute (blog), 18 March 2016.

57. Katherine Koleski, The 13th Five-Year Plan (Washington, DC: US-China Economic and Security Review Commission, 2017), 3.

58. Koleski, The 13th Five-Year Plan, 16-21.

59. Koleski, The 13th Five-Year Plan.

60. "China's 13th Five-Year Plan for Ecological \& Environmental Protection (20162020)," China Water Risk, 9 December 2016.

61. "China's 13th Five-Year Plan for Ecological \& Environmental Protection (20162020).”

62. Koleski, The 13th Five-Year Plan.

63. Koleski, The 13th Five-Year Plan, 18.

64. Koleski, The 13th Five-Year Plan, 18.

65. Koleski, The 13th Five-Year Plan, 19.

66. Koleski, The 13th Five-Year Plan, 19-20.

67. Koleski, The 13th Five-Year Plan, 20.

68. Henderson et al., "5 Questions."

69. Koleski, The 13th Five-Year Plan, 21.

70. Koleski, The 13th Five-Year Plan.

71. "Why China Is at the Center of Our Climate Strategy," Environmental Defense Fund, accessed 19 June 2019.

72. "History of the Marshall Plan," George C. Marshall Foundation, accessed 4 March 2019.

73. "History of the Marshall Plan."

74. Caitlin E. Werrell and Francesco Femia, "A Marshall Plan to Combat Climate Change in the Asia-Pacific," E-International Relations, 7 February 2012.

75. Phil McKenna, "Global Emissions Rose in 2017, but U.S. and China Both Made Progress," Inside Climate News, 22 March 2018.

76. Nate Aden, "The Roads to Decoupling: 21 Countries Are Reducing Carbon Emissions While Growing GDP," World Resources Institute (blog), 5 April 2016.

77. "Is the Public Willing to Pay to Help Fix Climate Change?," Energy Policy Institute at the University of Chicago, accessed 24 July 2019, 3. 


\title{
Russia's Information Warfare Exploring the Cognitive Dimension
}

\author{
Blagovest Tashev, PhD; Lieutenant Colonel Michael Purcell \\ (Ret); and Major Brian McLaughlin (Ret)
}

\begin{abstract}
The U.S. military increasingly invests in capabilities to meet challenges from the growth of strategic competition in the information environment, which is aimed at influencing and disrupting adversaries and other groups. By analyzing Russia's approach to information warfare, this article adds to the current understanding of the Russian modus operandi in the information environment. The article argues that the success of competitive strategies in this domain requires not only investment in its technical and informational dimensions but also deep knowledge of its most important one-the cognitive dimension. The article concludes with recommendations to incorporate cognitive dimension considerations in Marine Corps operations in the information environment.
\end{abstract}

Keywords: information warfare, Russia, cognitive dimension, deputy commandant for information, culture, Marine Air-Ground Task Force (MAGTF) information operations, operations in the information environment

$\mathbf{T}$

he U.S. military is increasingly investing in structures and capabilities to meet the challenges resulting from the exponential growth of strategic competition in the information environment. However, U.S. military

Blagovest Tashev has expertise in Eastern Europe and Eurasia and currently works in the Translational Research Group at Marine Corps University's Center for Advanced Operational Culture Learning (CAOCL). LtCol Michael Purcell is a former armor officer and Eurasian foreign area officer with extensive operational experience in the former Soviet space. Maj Brian McLaughlin is a former infantry officer, Eastern European foreign area officer, and crypto-linguist, who is focused on Ukrainian security and politics and developing curriculum at CAOCL to ensure deploying forces are better prepared to operate among foreign populations. The views presented in this work are the authors' own. 
professionals continue to face difficulties addressing the intangible elements inherent to this form of confrontation. Success in this realm requires not only effectiveness in the physical and informational dimensions but also intimate knowledge of the cognitive dimension of the information environment. Russia's approach to information warfare provides valuable insights into the complexity of this issue for military and national security professionals.

The purpose of this article is to advise information operations professionals and improve their understanding of the cognitive dimension. This article addresses the evolving role of information warfare in Russia's strategy for interstate power competition and argues that, to successfully counter it, American military professionals must come to terms with Russia's philosophically different understanding and approach to the cognitive dimension in the information environment.

In the last decade, Russia has reemerged as a significant power player capable of exerting influence beyond its immediate neighborhood. Starting with the invasion of Georgia in 2008, Russia gradually expanded its military presence in Central Asia, annexed Crimea from Ukraine in 2014, provoked and supported an ethnic Russian insurgency in Eastern Ukraine, and intervened militarily in support of the ruling regime in Syria. ${ }^{1}$ Simultaneously, Russia broadened security cooperation missions in the greater Middle East region, Africa, Asia, and South America, while Russia's Aerospace Forces and the Navy are increasing their long-range patrols. This widened presence abroad was made possible by massive military modernization at home. ${ }^{2}$ The country has reformed both the structure and the capabilities of its armed forces and has successfully used them as a credible instrument of national power. Russia's return to global politics has been a long process. Yet, it was the annexation of Crimea and the revelation of Moscow-directed interference in the U.S. presidential elections in 2016 that thrust this process into public discourse, which seems to have shifted Washington's attitude toward Russia's reemergence as a global player. Accordingly, U.S. national security documents, including the National Security Strategy (NSS) in 2017 and the National Defense Strategy (NDS) in 2018, identified Russia, along with China, as a threat to national security.

One particular aspect of Russia's expanding power that has garnered considerable attention is its use of information warfare. While Western national security professionals have noted Russia's use of information in the short Russia-Georgia war in 2008 and in the wake of Russia's intervention in Ukraine starting in 2014, the American public and Washington, DC, in general have become obsessed with this after Russian interference in the 2016 U.S. presidential elections. Since then, the national security elite and the public have begun to pay more attention to Russia's information operations in Europe and elsewhere. ${ }^{3}$ Russia's information warfare feeds into U.S. concern about the growing 
impact of stratagems employed by states to control the narratives surrounding their operations while aiming to influence the decision making and behavior of other actors. The trend is facilitated by the proliferation of technologies and the growing use of the internet and social media as well as changing human habits of acquiring and using information. Accordingly, both the NSS and NDS highlight threats to U.S. security stemming from the use of information by adversaries.

The growing emphasis on threats emanating from the information environment prompted the creation of a seventh warfighting function by the Chairman of the Joint Chiefs of Staff in 2017. Accordingly, the U.S. Marine Corps added a deputy commandant for information to synchronize the efforts of those disparate functions related to the information environment already organic to the Marine Corps. U.S. Department of Defense publications providing doctrine for information operations identify the information environment as including the physical, informational, and cognitive dimensions. ${ }^{4}$ Information Operations, Joint Publication 3-13, describes the information environment as consisting of the human-centric cognitive dimension, the data-centric information dimension, and the tangible physical dimension. ${ }^{5}$ It goes on to explain the cognitive dimension as encompassing "the minds of those who transmit, receive, and respond to or act on information." "The Marine Air Ground Task Force Information Environment Operations Concept of Employment lays out the approach to fighting and winning through and in the information environment. ${ }^{7}$ According to the publication, the cognitive dimension includes "the knowledge, attitudes, beliefs, and perceptions of people." ${ }^{8}$ In the same section, elements of the cognitive dimension are represented as a list of possibilities, "such as the decisionmaker's culture, life experiences, relationships, outside events, ideology, and the influences of those inside and outside of [a] decisionmaker's group." 9

While organizing, equipping, and training to face the more tangible physical and informational dimensions of the information environment, the U.S. Marine Corps is only beginning to realize the difficulties of the least tangible dimension. This article first offers a short analysis of the elevation of information warfare as a powerful instrument of national power as reflected in Russia's national security documents and thinking about warfare. It then proceeds to address some issues with the Western analysis of Russia's way of competition in the information environment. In the next section, we offer several factors that need to be included in the analysis of Russia's information warfare. The article concludes with recommendations about the Marine Corps' approach to countering Russian information warfare and more specifically about addressing the cognitive dimension-the most important dimension in the information environment. 


\section{A Terminology Issue}

The use of the term information warfare in American public discourse to describe Russia's interference in the internal political affairs of other countries is problematic. Like other terms, such as hybrid warfare, information warfare has no doctrinal definition and is correspondingly ambiguous. Its meaning is further diluted or outright misused by practitioners at the operational level in fields that would be better considered as subsets of the term information warfare. The general notion of information warfare as a "strategy for the use and management of information to pursue a competitive advantage, including both offensive and defensive operations" as described by the Congressional Research Service (CRS), is often used liberally to describe narrower activities, such as network operations, psychological operations, electronic warfare, operations security, and military deception. ${ }^{10}$

This conflict is in part due to the operationalization of information warfare in the United States, which is bound by the confines of legal and cultural barriers. In practice, "much of the current information warfare doctrine and capability resides with the military." 11 However, the U.S. military's doctrine, capabilities, and functions (a.k.a. information operations) do not address the strategic level, but rather the operational and tactical ones. In addition, as the report of the CRS points out, Title 10 U.S.C. $\$ 2241$ prohibits the Department of Defense (DOD) from domestic "publicity or propaganda." 12 Although the U.S. military is expected to be involved in information warfare, there are barriers to its ability to influence beyond the operational level of war. At the same time, there seems to be no other institution in the U.S. government entrusted with a role in information warfare at the strategic level.

It has been pointed out by others that the U.S. military used to have a more comprehensive and holistic approach to information warfare and at some points even involved coordination and synchronization of policies and actions by military and nonmilitary agencies and structures. ${ }^{13}$ Gradually, however, the various information-related functions and organizations went in different directions. Very importantly, information warfare was increasingly associated with the military and warfighting, divorcing it from any broader-civilian, nonmilitary, and peacetime-efforts in the information environment.

This is a critical point, as the discussion below will indicate that Russia not only faces fewer legal and cultural barriers to influence at the operational and strategic level during both war and peace, but it also has philosophically different approaches and goals while operating in the information environment. The multiple issues with the definition of information warfare in the United States notwithstanding, even the most expansive understanding of the term fails to capture the nature of the approach adopted by Russia. As Timothy Thomas observed, what is really different in the Russian approach "is the conceptual 
understanding of an information operation from a cultural, ideological, historical, scientific, and philosophical viewpoint." ${ }^{14}$ As the rest of this article will point out repeatedly, the distinct nature of Russia's approach is so different from the American approach that many argue for adopting a new term that better captures Russia's way and avoids mixing it with the Western conceptualization of operations in the information environment. One author, for example, calls for adopting IPb, a shorthand for the Russian term информационное противоборство, loosely meaning "information confrontation." ${ }^{15}$ For the purpose of this article, however, we will continue to use the term information warfare, despite its shortcomings.

\section{Russia's Elevation of Information Warfare}

Through its strategic documents, Russia consistently indicates that it seeks to adopt a comprehensive and coordinated approach to gaining security and successfully advancing its interests. This effort is envisioned as the integration of multiple instruments of power and the involvement of both national institutions and nongovernmental actors. In fact, the body of strategies, doctrines, and government-promoted narratives suggests that the successful promotion of Russia's national interests requires the involvement of the entire society. Russia has also increasingly placed emphasis on nonmilitary means as a way to gain security, even as the country is involved in an ambitious military modernization. ${ }^{16}$ According to General Valery V. Gerasimov, chief of the General Staff of the Armed Forces of the Russian Federation, the ratio of nonmilitary to military measures in the modern security environment is $4: 1$, even as nonmilitary competition comes under the aegis of the military. ${ }^{17}$ To the best of our knowledge, this is the only reference Gerasimov, or any other high-ranking Russian military official, has made to this ratio. One can reasonably suspect that the chief of the General Staff is paying lip service to the increasingly large role nonmilitary measures are playing in confrontations between states; the Russian military elite is still focused on preparing the armed forces to prevail in a kinetic confrontation with other states. There is little doubt, however, that the Russian military recognizes the utility of nonmilitary measures in interstate confrontation, especially during what would be considered peacetime.

This way of thinking is leading to an evolution in the Russian way of warfare; while the military is not necessarily departing from the big-war paradigm, decision makers in Moscow are increasingly focusing on how defense structure and posture, along with nonmilitary instruments, shape the strategic environment in line with Russia's preferences. ${ }^{18}$ Accordingly, information warfare is increasingly central to a state's arsenal to use against other states in confrontation, wherein countries' elites and public perceptions are becoming the center of gravity in determining confrontation outcomes. The goal of information 
warfare is to influence both the adversary's strategic calculus and the public's behavior. ${ }^{19}$ As Aleksander Dvornikov, commander of Russia's Southern Military District, points out in the Russian publication Military-Industrial Courier, "Now states achieve their geopolitical goals through the application of complex non-military measures, which often are more effective than the military ones. The main goal of these measures is not the physical destruction of the enemy but the complete submission of his will." ${ }^{20} \mathrm{He}$ goes on to argue that without information operations, Russia would not have succeeded in many operations in Syria.

Not surprisingly, Russia is implementing policies and practices designed to promote information warfare to a level of parity with nuclear and conventional power. This struggle to shape other states' perceptions and calculus is constant, even during peacetime and periods of cooperation; thus, the lines between peace, conflict, and war are blurred. As General Gerasimov puts it, "military conflicts have not gone beyond the bounds of the conventional nature of war; their components are types of struggle such as direct armed struggle, political struggle, diplomatic struggle, information struggle, et al." ${ }^{21}$ While the U.S. approach to warfare, largely conditioned by political and legal constraints, makes a relatively clear distinction between war and peace and restricts methods and capabilities accordingly, Russian thinking displays a willingness to harness the power of all national institutions in a continuous struggle with its opponents, both current and potential. Ironically, Russian strategists see the elevation of informational instruments of influence, the blurring of the line between peace and war, and even hybrid warfare as innovations advanced and practiced by Western powers. ${ }^{22}$ Hence, Russia is simply adapting to the new type of warfare. While the enemy's economy and state command and control system will continue to be priority targets, the information sphere becomes a new critical operating environment. ${ }^{23}$

Of course, one should not take what we pointed out as the American proclivity to make a clear-cut distinction between war and peace to the extreme. This is simply a tendency. There is already evidence that this is changing. Most recently, the DOD released Competition Continuum, Joint Doctrine Note 1-19, which points out that the joint force traditionally "employs many constructs and procedures that reflect an artificial distinction between an environment of armed conflict and peace." Instead, it calls for the adoption of a "competition continuum," a construct that better describes "a world of enduring competition conducted through a mixture of cooperation, competition below armed conflict, and armed conflict." ${ }^{24}$ This is a step in the right direction. However, changing long-established, historically, culturally, and doctrinally shaped attitudes in the U.S. military toward warfighting will take years. The growing popularity of 
terms such as hybrid war, political warfare, and gray zone conflict in the United States also point out American attempts to rationalize what is seen as a new type of confrontation between states (of course one should also ask if this is a new political phenomenon). Russia, conversely, has long seen relations between states as inherently and constantly competitive.

Russia's attention to changing trends in the information environment is reflected in official security-related documents. The Russian 2015 National Security Strategy (NSS) identifies informational security as one of the components of national security along with the state, public, environmental, economic, transportation, energy, and individual components. ${ }^{25}$ The Russian NSS goes on to point out that the United States and its allies are attempting to contain Russia by exerting political, economic, military, and informational pressure on it. In general, Russia sees an intensifying confrontation in the global information arena as some states (meaning the West) use information and communication to achieve their geopolitical objectives.

Russia's NSS is specifically concerned with Western attempts to use information as a tool to interfere in Russia's domestic affairs to weaken "traditional Russian spiritual and moral values" and to threaten the "unity of the Russian Federation's multinational people." ${ }^{26}$ Likewise, The Foreign Policy Concept of the Russian Federation pledges to respond to these challenges by continuing to focus on traditional measures to ensure strategic deterrence. ${ }^{27}$ Internally, the state also tasks itself with implementing policies "aimed at strengthening and augmenting traditional Russian spiritual and moral values," in other words, creating resilience against foreign cultural influences. This focus on traditional Russian values is not new. In a wide-ranging series of interviews in 2000, when asked what the country needed most, then-acting President Vladimir Putin responded, "moral values." 28

The Military Doctrine of the Russian Federation also acknowledges the changing nature of warfare, especially the integrated use of military force, political, economic, informational, and other nonmilitary measures. Accordingly, it calls for the "development of forces and means of information warfare." ${ }^{29}$ While the United States has struggled to define information warfare and formulate a comprehensive approach to confrontation in the information space, Russian institutions, security professionals, and analysts seem to have reached a consensus on the nature of the confrontation. According to Russia's Ministry of Defence:

Information War is the confrontation between two or more states in the information space with the purpose of inflicting damage to information systems, processes and resources, critical and other structures, undermining the political, economic and social systems, a massive psy- 
chological manipulation of the population to destabilize the state and society, as well as coercion of the state to take decisions for the benefit of the opposing force. ${ }^{30}$

Similarly, in a political-military dictionary, edited by Russia’s former ambassador to NATO, Dmitry Rogozin, information warfare (информационная война) is defined as an "intensive struggle in the information environment with the aim of achieving informational, psychological and ideological superiority, damaging information infrastructure, undermining political and social systems, as well as psychologically shaping military personnel and populations." ${ }^{31}$ The entry suggests a philosophical approach to information warfare quite different from that in the West, which not only aims to influence the consciousness of groups in society but also to change their knowledge about basic social and natural phenomena, weakening their will to counter aggression. As this definition indicates, but also as numerous publications of Russian defense analysts attest, Russia's approach to information warfare is very different from the American approach to information operations. ${ }^{32}$ It is based on different cognitive, ethical, legal, and cultural norms and practices.

Russia's distinct approach to information warfare is informed by a view on the nature of conflict in the international system that starkly contrasts with that of the United States. The roots of the Russian security elites' thinking have been subject to lengthy and sophisticated debate, but there is little doubt that one of the most dominant narratives in Russia's collective consciousness is one of a country standing alone without enduring alliances, constantly targeted by malign foreign designs. ${ }^{33}$ Although Russia has a history of balancing external threats by alliance formation-most recently through the Warsaw Pact (1955 Treaty of Friendship, Cooperation, and Mutual Assistance) during the Cold War-the country currently sees itself as dangerously exposed and alone. This conception is of course founded on a long history of conflict with Western peoples, such as the Poles, French, Germans, and Americans, as well with those from the East, such as the Mongols and Japan.

This outlook was reinforced by the Marxist-Leninist ideology, particularly dialectical and historical materialism, with its emphasis on human history as the result of a constant struggle between social classes and states. In this view, while socialist states were free of domestic and external conflicts because they were classless, the capitalist countries, in contrast, were always involved in domestic and foreign conflicts. That made the international system inherently conflictual, a condition that would disappear only when the entire world became socialist. ${ }^{34}$ Even when various Soviet leaders embraced "peaceful coexistence" or "détente" with the capitalist camp, those were considered tactical pauses in the inevitable showdown between the socialist states and imperialists. ${ }^{35}$ While Marxist- 
Leninist ideology was arguably not the most important source of Soviet foreign policy, generations of Russians were educated and socialized in its teachings ${ }^{36}$ The use of terms such as imperialism, exploitation, world domination, and fascism introduced in the social lexicon through education and social discourses during Soviet times - are still frequently employed to describe Russia's opponents. One does not have to look hard to find outlooks in modern Russia that harken back to Soviet beliefs about the nature and extent of confrontation between states. Addressing the audience at a conference organized by the Russian Academy of Military Sciences, for example, General Valery Gerasimov pointed out that the increased struggle between states is caused by the U.S. quest for global dominance. This struggle involves political, economic, and informational tools, and encompasses all spheres of social activity including diplomacy, science, sport, and culture. Although this struggle is mostly nonmilitary, war cannot be excluded as an instrument. In his words, the confrontation is total. ${ }^{37}$

Marxism-Leninism influenced another aspect of the Soviet (and by extension Russian) approaches to information warfare. In this school of thought, the working masses possessed revolutionary potential in their struggle with the capitalist class. However, this potential needed to be translated into a political program; it was the role of the professional revolutionaries organized in a vanguard party (later to be known as the Communist Party) that organized, educated, and provided direction. The party needed to organize the masses with purpose and direction. That required that party members go among the classes as theoreticians, propagandists, agitators, and organizers. ${ }^{38}$ The working class had to be trained in political consciousness, in understanding their true interests, and in embracing the revolutions as the way to liberation from exploitation. The Communist Party's efforts to actively shape the consciousness of the masses did not end with the assumption of power. Instead, it became a permanent activity, part of the party's goal of creating a new person- the Soviet manwhose consciousness and behavior aligned with ideological end states. ${ }^{39}$ While the influence of Marxism-Leninism only partly explains the Russian approach to information warfare, it adds some understanding of the Soviet and Russian experience in targeting people's minds. In other words, better understanding requires exploration of the ideological foundations of Russia's long military tradition of information warfare.

\section{But How Do They Do It?}

A note of caution is in order at this point. Russian politicians, military leaders, and analysts talk and write about information warfare. However, most of their analyses seem to be their reading of how the West is conducting information warfare against Russia and others. Such analyses almost always include a description of the information threats Russia is facing and multiple examples of 
how the West is conducting information warfare. What is absent, however, is a description or prescription of how Russia is conducting or should conduct information warfare. This paradox is evident even in Russian strategic documents. They include long lists of information threats faced by the country and the armed forces but provide little insight into how the country or the armed forces should respond to those threats and conduct their own operations at the strategic, operational, and tactical level. While U.S. doctrinal publications related to information warfare, including information operations, psychological operations, public affairs, civil-military operations, etc., are available to the public, similar Russian documents, if they exist, are neither available nor discussed in public forums. ${ }^{40}$ What little is publicly available provides no insights into strategy, tactics, techniques, and procedures. Russia's Information Security Doctrine of the Russian Federation, for example, is long on identifying national interests, threats to those interests in the information space, and calls for action, but there is little about how Russia operates in this sphere. Nevertheless, these documents are useful as they provide insight into Russian thinking about the information environment in general. ${ }^{41}$

Russia's traditional lack of openness on security and defense issues has led Western analysts on a quest to come up with concepts and terms that best capture Russia's approach to information warfare and its place in the country's overarching strategy. Accordingly, terms such as hybrid warfare, Gerasimov doctrine, gray zone activities, reflexive control, and political warfare have been introduced or borrowed in attempts to capture the nature of Russia's activities in the information space, and more generally Russia's overall strategy. ${ }^{42}$ The proliferation of concepts notwithstanding, there is limited evidence that they provide substantial analytical value in the attempts to gain knowledge in Russia's strategy and more specifically in Russian information warfare. The result of this approach to the analysis is that the nature and meaning of Russia's actions are determined by the logic of those concepts and terms. If the hybrid war concept is used, for example, any Russian actions will be seen as a hybrid war action and a goal that may have nothing to do with the actual Russian intent and goal. Similarly, although one can come across multiple articles written in the West on the concept of "reflexive control" as the basis of Russian information warfare, one fails to find studies providing evidence and case studies of the application of reflexive control above the tactical and arguably the operational level. ${ }^{43}$

Rather than design a new one, or modify an existing concept that fully captures Russia's way of information warfare, it is more practical to look at how exactly the Russians approach interaction in the information space and attempt to understand the logic of their approach from the Russian perspective. There are historical, philosophical, cultural, military, and ethical rationales for the nature of Russia's approach. We need to accept that the logic of this approach 
is not necessarily similar to the logic that dominates the Western approach, lest we are to fall into the psychological traps of confirmation or selection bias in our understandings of Russian approaches.

\section{On the Nature of Russia's Information Warfare}

Rather than fit Russia's approach to information warfare into a neat, allencompassing concept, one should start off with several considerations that inform a systematic analysis of Russian actions. What follows are the considerations, in no particular order, as each one must be analyzed in the context of a unified Russian strategic approach.

The Russian approach is holistic. It aims to not only affect the target state and its armed forces' ability to manage information and exercise effective command and control functions but also to achieve desired effects in the mind of target populations' perceptions and decision-making processes that favor Russia's interests and goals. This is a two-pronged approach that seeks to affect both the physical and the cognitive dimensions of the information environment. At the physical level, what the Russians call the digital-technological level, they seek to disrupt and compromise the physical dimension of the information environment by penetrating, manipulating, and destroying information networks and command and control systems. In the last decade, the Russian military has deployed multiple new electronic warfare systems, completing a similar modernization in agencies outside the armed forces, including the intelligence services. ${ }^{44}$ Russia's increasing emphasis on information warfare is reflected in its growing investments in information warfare capabilities and structures. In 2017, Russia acknowledged the establishment of a new branch of the military-information warfare troops. ${ }^{45}$ At the same time, at the cognitive level, the Russians have already demonstrated the ability to integrate actions in the physical dimension of operations in the information environment with actions intended to affect perceptions and decision-making processes; in other words, they are achieving effects in the cognitive dimension. ${ }^{46}$

Russia has a whole-of-government approach to information warfare. While information operations in the United States are seen as mostly a military activity, Russia uses a more expansive approach, including multiple government bodies and agencies and both military and nonmilitary methods and instruments. In addition, Russia considers information warfare to be an effort that involves nongovernmental players, in fact, requiring the efforts of all of society.

According to the Russian view, not just the state but the entire society is the target of foreign-led information warfare, so the society must be protected and must participate in actively resisting foreign information campaigns. The whole-of-government approach has important consequences for the nature of the Russian method. While the American military tends to focus on the capa- 
bilities of a foreign military, this approach underestimates Russia's information warfare capabilities as most of them are not organic to the Russian armed forces. While the armed forces certainly possess information warfare capabilities, particularly electronic and cyber warfare capabilities, the bulk of Russia's capabilities to target the cognitive dimension of a population and key decision makers with culturally and politically sophisticated information and messaging are to be found outside the military. And, of course, one should always include the Russian military as a whole as an information warfare tool. Military modernization, snap readiness checks, large military exercises-including multinational ones-security cooperation events with foreign militaries, and increased military presence abroad are used not only to increase readiness but also to communicate, demonstrate, and intimidate. In short, the military is not only a tool to win in a force-on-force confrontation but also a tool to affect the strategic calculations of key foreign decision makers and the attitudes and beliefs of civilian populations. ${ }^{47}$ This is an example of the use of the military at the strategic level of information warfare.

The use of the military in shaping the strategic calculus of other states as discussed above brings about another important point. Ultimately, both the Russian and the U.S. approaches to deterring each other is about shaping the other side's thinking. The communication to the other side, however, is viewed through the perspective of the communicating country. The value of this communication depends entirely on the effect it has on the other side. Very often, however, what one side communicates to the other-through words, actions, postures, etc.- - is not what the other side hears. This is why knowledge of the cognitive dimension matters-understanding the opposite side's interests, frames of reference, outlooks, and thought processes not only increases effectiveness in confrontation in the information space but also avoids dangerous misunderstandings and conflict escalations.

Russia's approach is very flexible and adaptable. Many have tried to discern patterns in how the Russians conduct information warfare as an attempt to anticipate and predict future operations. It is becoming clear that these attempts provide limited predictive value. If anything, the Russian approach does not seem to be married to a doctrine. Instead, what is evident is innovation, flexibility, adaptability, and no fear of failure. When an approach seems to be failing, the Russians quickly adopt another one.

Above all, the whole-of-government approach allows for the fourth aspect that must be taken into consideration. That is, the Russians will quickly resort to kinetic action when they see that nonkinetic methods, including those using information operations, do not work. ${ }^{48}$ What also makes the flexible use of kinetic and nonkinetic methods possible is the Russian system of governance that, while lacking in transparency and institutional checks and balances, allows 
for short decision-making cycles. Of course, this type of decision making also makes it prone to miscalculations and failure to anticipate second- and thirdorder effects of selected courses of action.

The discussion of the Russian flexibility in the use of kinetic and nonkinetic actions is an appropriate place for a note of caution. Although information warfare is becoming an increasingly prominent method in the pursuit of national interests, the Russians have in no way forsaken the use of force as an instrument of national power. While the attention the West is paying to growing Russian activity in the information space is fully deserved, one must never ignore the fact that the most significant development in Russia's growing national power is the country's successful military modernization and the transformation of the armed forces into an effective instrument of national power. In fact, one might plausibly argue that Russia's growing military power allows it to use information warfare methods more aggressively as it feels confident enough the military possesses enough power to deter other states from responding more aggressively to information campaigns.

Russian information warfare is uninterrupted and constant, meaning that it is waged during both war and peace. While Western states tend to make a distinction between war and peace, in the Russian thinking, states are constantly engaged in a struggle for security, influence, and resources. Accordingly, even absent war, states engage in an information struggle trying to influence each other's perceptions and decision making, while also targeting populations, both domestic and foreign, trying to influence their consciousness. It is therefore no surprise that Russia sees the promotion of human rights, democracy, and Western preferences for international order as a form of warfare, targeting Russian interests and the state's social cohesion and resilience. The Russian political and military elite, for example, see any attempts to promote democracy in its neighborhood, or anywhere else for that matter, as only initial Western steps to prepare the ground for regime change that will lead to Western expansion, including a military one, in these states.

The strong strain of conspiratorial thinking that traditionally runs through Russian attitudes toward the West also promotes a normalization of information warfare as a legitimate and necessary tactic of the state. Almost anything Americans - and the West in general - say and do is often perceived as part of a nefarious propaganda campaign designed to promote Western interests and undermine Russia. ${ }^{49}$ This campaign is believed to be constant and widespread, using diverse instruments of influence ranging from diplomatic, economic, cultural, and informational. ${ }^{50}$ This campaign requires a Russian response, including in the information space. In a discussion on the global information environment organized by the St. Petersburg International Economic Forum in 2018, Margarita Simonyan, RT's editor-in-chief, pointed out that the glob- 
al media environment has long been dominated by "Anglo-Saxon media outlets." ${ }^{1}$ However, she asserted that the appearance of alternative media voices, including Russian ones, has challenged that status quo. This, she argued, explains why these alternative outlets have become targets of Western intelligence services and private media with ties to intelligence services. ${ }^{52}$ Russia sees itself as being at a disadvantage, what some call "information inequality," a situation that justifies the steps taken to address this weakness, such as the proliferation of Russian state-sponsored television and radio channels (e.g., RT, Sputnik) and institutions promoting the official Russian point of view abroad. ${ }^{53}$ The increasing Russian presence in the international information space is seen as part of Russia's return as a global power. Understanding this dynamic explains why those who hope to see an end of Russian presence in America's information space are badly misguided.

Because the Russians have a long tradition of waging information warfare, conduct it constantly, and have flexibility without many checks and balances does not automatically mean that they are very successful practitioners. It is high time we engage in a sober assessment of Russia's information warfare's effectiveness. Much of the writing on the subject tends to exaggerate the effectiveness of Russian information warfare. This is perhaps understandable in the political climate created by Russia’s interference in the 2016 presidential elections. Instead, a careful study of Russia's multiple information operations must be completed in the United States and abroad. Our own study of Russian actions, granted they are confined to observations in several countries in Europe, tentatively leads us to believe that Russia has achieved only mixed successes while failures are abundant. ${ }^{54}$

Knowledge and information about Russian information warfare in various countries are valuable lessons; however, those lessons might not amount to a pattern that provides analytical value. The Russians tailor their approach according to their understanding of the varying vulnerabilities of target populations, context, and intended end results. How they approach a target population in Ukraine, in the European Union, and in the United States, for example, will differ. This is a good indicator that the Russians take the cognitive dimension seriously - adopting a course of action that takes into consideration the cultural, historical, ideological, and contextual factors relevant to the target population and the goals of the Russian actions.

Russia might be actively exploiting the cognitive vulnerabilities in foreign states and groups, but the country also has its own vulnerabilities. In fact, that explains why the state is active in the information environment-it sees other states and groups targeting the Russian state and society's vulnerabilities. While the West sees Russia as conducting offensive campaigns in the information 
space, Russia sees its actions as defensive measures. The existence of perception and misperceptions on both sides notwithstanding, the Russian state and society do have multiple cleavages and frictions that could be exploited by outside actors.

\section{Recommendations for the Marine Corps}

As the Marine Corps adapts to increase the effectiveness of its operations in the information environment, especially regarding the cognitive dimension, it is vital to study Russia's approach toward information warfare.

When confronting Russia, the Marine Corps must understand that it is not dealing solely with the Russian armed forces - let alone with one of its components-but rather with the Russian state. In addition to addressing the threats posed by information warfare capabilities organic to the Russian military, it is facing an information campaign waged by the state's intelligence services, the Ministry of Foreign Affairs, and nongovernmental actors, including the Russian Orthodox Church, patriotic organizations, independent and contracted cyber hackers and trolls, business people with ties to the Kremlin or seeking the Kremlin's favors, and criminal groups with ties and no ties to state agencies. Addressing all these actors is a tall order and the Marine Corps should not aim to do that. Instead, the focus should be to see Marine Corps information warfare efforts as an element in a larger United States, NATO, and European Union effort to confront Russia's information warfare campaigns. This also is a tall order, but the only viable option.

Furthermore, since Russian information warfare efforts target multiple populations, the Marines should be prepared to work with populations exposed to those efforts. Allied military personnel and civilian populations, too, are targets, and Marines need to develop knowledge and information about the target populations' vulnerabilities and resilience levels regarding Russian information warfare threat as well as the local institutions' own capabilities and methods to affect Russian perceptions and decision making. Simply put, knowing the Russian way of information warfare is not sufficient; the Marines must have knowledge and information about how the Russians target specific groups among the military partner or friendly population in the Marines' area of operations and how partners, in turn, fight back in the information space.

Successful operations in the information environment require mastering its most important dimension-the cognitive one. Above all, that means gaining knowledge and information about target groups' culture, history, ideologies, experiences, relationships, and influences that affect those populations' decisionmaking processes. Developing this knowledge is a time-consuming and expensive process, one that the military cannot hope to achieve in isolation and 
integrate it as an organic capability. However, there are ways to integrate the military's limited capabilities in this area with ones existing in government and nongovernmental agencies and actors.

\section{Notes}

1. Sultan-Khan Zhussip, "Russia Expands Its Military Presence in Central Asia," Radio Free Europe/Radio Liberty, 12 November 2008. It must be pointed out that after the disintegration of the Soviet Union, Russian troops never left Moldova, Georgia, and Tajikistan, where they were active participants in civil wars and after cease-fire agreements stayed as peacekeepers.

2. Russia Military Power: Building a Military to Support Great Power Aspirations (Washington, DC: Defense Intelligence Agency, 2017).

3. There is a growing body of research into Russia's information warfare, along with attempts to conceptualize the country's approach. See, for example, Timothy L. Thomas, Dialectical versus Empirical Thinking: Ten Key Elements of the Russian Understanding of Information Operations (Fort Leavenworth, KS: Foreign Military Studies Office, Center for Army Lessons Learned, 1998); Timothy L. Thomas, "Russia's Reflexive Control: Theory and the Military," Journal of Slavic Military Studies 17, no. 2 (2004): 237-56, https://doi.org/10.1080/13518040490450529; Timothy L. Thomas, Crafting an Information Warfare and Counter-propaganda Strategy for the Emerging Security Environment, 115th Cong. (15 March 2017) (hearing before the Subcommittee on Emerging Threats and Capabilities of the Committee on Armed Services); Donald N. Jensen and Peter B. Doran, Chaos as a Strategy: Putin's "Promethean" Gamble (Washington, DC: Center for European Policy Analysis, 2018); Stephen Blank, "Cyber War and Information War à la Russe," in Understanding Cyber Conflict: 14 Analogies, ed. George Perkovich and Ariel E. Levite (Washington, DC: Georgetown University Press, 2017), 81-98; Dmitry (Dima) Adamsky, "From Moscow with Coercion: Russian Deterrence Theory and Strategic Culture," Journal of Strategic Studies 41, nos. 1-2 (2018): 33-60, https:// doi.org/10.1080/01402390.2017.1347872; Charles K. Bartles, "Getting Gerasimov Right," Military Review (January-February 2016): 30-38; Keir Giles, Handbook of Russian Information Warfare, Fellowship Monograph No. 9 (Rome, Italy: NATO Defense College, 2016); Keir Giles, The Next Phase of Russian Information Warfare (Riga, Latvia: NATO Strategic Communications Centre of Excellence, 2016); Heather A. Conley et al., The Kremlin Playbook: Understanding Russian Influence in Central and Eastern Europe (Washington, DC: Center for Strategic and International Studies, 2016); Heather A. Conley et al., The Kremlin Playbook 2: The Enablers (Washington, DC: Center for Strategic and International Studies, 2019); Linda Robinson et al., Modern Political Warfare: Current Practices and Possible Responses (Santa Monica, CA: Rand, 2018), https://doi.org/10.7249/RR1772; Todd C. Helmus et al., Russian Social Media Influence: Understanding Russian Propaganda in Eastern Europe (Santa Monica, CA: Rand, 2018), https://doi.org/10.7249/RR2237; Bettina Renz and Hanna Smith, Russia and Hybrid Warfare-Going Beyond the Label (Helsinki, Finland: Kikimora Publications, 2016); and Keir Giles, Russia's "New" Tools for Confronting the West: Continuity and Innovation in Moscow's Exercise of Power (London, UK: Royal Institute of International Affairs, Chatham House, 2016).

4. Department of Defense Dictionary of Military and Associated Terms, Joint Publication (JP) 1-02 (Washington, DC: Department of Defense, 2010), 110.

5. Information Operations, JP 3-13 (Washington, DC: Department of Defense, 2014), figure I-1, p. I-2.

6. Information Operations, figure I-1, p. I-2.

7. Marine Air Ground Task Force Information Environment Operations Concept of Employment (Quantico, VA: Headquarters Marine Corps, 2017), 22.

8. Marine Air Ground Task Force Information Environment Operations Concept of Employment, 22. 
9. Marine Air Ground Task Force Information Environment Operations Concept of Employment, 24.

10. Defense Primer: Information Operations (Washington, DC: Congressional Research Service, 2018); and Catherine A. Theohary, Information Warfare: Issues for Congress (Washington, DC: Congressional Research Service, 2018).

11. Theohary, Information Warfare, 7.

12. Title 10 Armed Forces, U. S. C. $\$ 2241$ (2012).

13. Conrad Crane, "The United States Needs an Information Warfare Command: A Historical Examination," War on the Rocks (blog), 14 June 2019. See also Conrad C. Crane et al., A Return to Information Warfare (Carlisle, PA: Historical Services Division, U.S. Army Heritage and Education Center, U.S. Army War College, n.d.).

14. Timothy L. Thomas, "Dialectical versus Empirical Thinking: Ten Key Elements of the Russian Understanding of Information Operations," Journal of Slavic Military Studies 11, no. 1 (1998): 40-62, https://doi.org/10.1080/13518049808430328.

15. Olga Vartanova, Gerasimov Doctrine as an Active Measure of Russian IPb (Quantico, VA: Marine Corps Intelligence Activity, 2017).

16. Valeriy Gerasimov, “Ценность науки в предвидении,” Военно-промышиленный курьер, 26 February 2013.

17. Gerasimov, "Ценность науки в предвидении."

18. Adamsky, "From Moscow with Coercion," 33-60.

19. Adamsky, "From Moscow with Coercion," 40-41.

20. Aleksandr Dvornikov, “Штабы для новых войн," Военно-промыциленный курьер, 23 July 2018.

21. Gen Valery Gerasimov, Russian Federation Armed Forces, "Contemporary Warfare and Current Issues for the Defense of the Country," trans. Dr. Harold Orenstein, Military Review (November-December 2017): 24.

22. Gen Valery Gerasimov “Мир на гранях войный," Военно-промышиленный курьер, 13 March 2017.

23. One may argue that the American concept of gray zone conflicts (a.k.a. competitive zones) is a partial attempt to address the Russian understanding of the struggle between states, which makes no clear-cut distinction between peace and war as it exists in Western military thinking.

24. Competition Continuum, Joint Doctrine Note 1-19 (Washington, DC: Joint Chiefs of Staff, 2019). See also Joint Concept for Integrated Campaigning (Washington, DC: Joint Chiefs of Staff, 2018).

25. Russian National Security Strategy (Moscow: Russian Federation, 2015).

26. Russian National Security Strategy, 21-22.

27. The Foreign Policy Concept of the Russian Federation (Moscow: Ministry of Foreign Affairs, 2016).

28. Vladimir Putin et al., First Person: An Astonishingly Frank Self-Portrait by Russia President Vladimir Putin, trans. Catherine A. Fitzpatrick (New York: PublicAffairs, 2000).

29. The Military Doctrine of the Russian Federation, No. Pr.-2976 (Moscow: Russian Federation, 2014).

30. Russian Federation Armed Forces' Information Space Activities Concept (Moscow: Ministry of Defence of the Russian Federation, 2000).

31. Dmitrii Rogozin et al., "Информационная война," in Война и Мир в Терминах и Определениях (Bucharest, Romania: Veche Publishing House, 2011) (authors' translation).

32. See for example, Leonid Savin, "Информационная война. Исторический экскурс и позиция России," Gepolitika, 21 March 2018.

33. For an excellent summary of Russia's strategic thinking, see Dmitri Trenin, "Russia's Threat Perceptions and Strategic Posture," in R. Craig Nation and Dmitri Trenin, Russian Security Strategy under Putin: U.S. and Russian Perspectives (Carlisle, PA: Strategic Studies Institute, U.S. Army War College, 2007): 35-47. See also Dmitry Gorenburg, "Circumstances Have Changed Since 1991, but Russia’s Core Foreign Policy Goals Have Not," PONARS Eurasia, January 2019. 
34. Vladimir Ilyich Lenin, Imperialism: The Highest Stage of Capitalism (Rookhope, UK: Aziloth Books, 2018).

35. Very early on, Soviet leaders recognized that taking on capitalist states head-on might be a tall order and adopted foreign policy accordingly while still believing in the inevitable violent clash with the capitalist world. See Jon Jacobson, When the Soviet Union Entered World Politics (Berkeley, CA: University of California Press, 1994).

36. Frederic J. Fleron Jr. et al., eds., Classic Issues in Soviet Foreign Policy: From Lenin to Brezhnev (New York: Aldine de Gruyter, 1991).

37. Viktor Hudoleev, “Военная наука смотрит в будущеe," Krasnaya Zvezda, 26 March 2018.

38. See chapter 3 in Vladimir Ilyich Lenin, "What Is to Be Done?: Burning Questions of Our Movement," Marxists Internet Archive, 1999.

39. The 22d Congress of the Communist Party of the Soviet Union, for example, adopted the "Moral Code of the Builder of Communism," the foundation of a superior ethical system aimed at further instilling Communist morality among citizens. See Deborah A. Field, "Moral Code of the Builder of Communism," Seventeen Moments in Soviet History. See also Herschel and Edith Alt, The New Soviet Man: His Upbringing and Character Development (New York: Bookman Associates, 1964); and Jay Bergman, "The Idea of Individual Liberation in Bolshevik Visions of the New Soviet Man," European History Quarterly 27, no. 1 (1997): 57-92, https://doi.org /10.1177/026569149702700103.

40. For a few examples, see Department of Defense Strategy for Operations in the Information Environment (Washington, DC: Department of Defense, 2016); Joint Concept for Operating in the Information Environment (JCOIE) (Washington, DC: Joint Chiefs of Staff, 2018); Information Operations; and Military Deception, JP 3-13.4 (Washington, DC: Department of Defense, 2012).

41. Information Security Doctrine of the Russian Federation, No. 646 (Moscow: Ministry of Defence of the Russian Federation, 2016).

42. See, for example, Michael Kofman, "Russian Hybrid Warfare and Other Dark Arts," War on the Rocks (blog), 11 March 2016.

43. See, for example, Margarita Levin Jaitner and Harry Kantola, "Applying Principles of Reflexive Control in Information and Cyber Operations," Journal of Information Warfare 15, no. 4 (Fall 2016): 27-38; and Thomas, "Russia's Reflexive Control Theory and the Military," 237-56.

44. On the modernization of the Russian electronic welfare capabilities, see Roger N. McDermott, Russia's Electronic Warfare Capabilities to 2025: Challenging NATO in the Electromagnetic Spectrum (Eesti, Estonia: International Centre for Defence and Security, 2017).

45. Vladimir Isachenkov, "Russia Military Acknowledges New Branch: Info Warfare Troops," Associated Press, 22 February 2017.

46. See, for example, a report by Col Liam Collins on examples of Russia's successful use of fires and information operations. Col Liam Collins, "Russia Gives Lessons in Electronic Warfare," Association of the United States Army, 26 July 2018, 18-19.

47. Russia's large Vostok-2018 military exercise, which also included Chinese troops, was meant to demonstrate close ties between the two countries, both of which see the United States as a threat. The message was not lost on the West. See "Russia and China Hold the Biggest Military Exercises for Decades," Economist, 6 September 2018.

48. Michael Kofman et al., Lessons from Russia's Operations in Crimea and Eastern Ukraine (Santa Monica, CA: Rand, 2017), https://doi.org/10.7249/RR1498.

49. Serghei Golunov and Vera Smirnova, "Proliferation of Conspiracy Narratives in Post-Soviet Russia: The 'Dulles' Plan' in Social and Political Discourses," Acta Slavica Iaponica, no. 37 (2016): 21-45.

50. Doctrine of Information Security of the Russian Federation.

51. RT is a Russian international television network funded by the Russian government.

52. “Сбалансировать картину мира»: в рамках ПМЭФ проходит обсуждение современных источников информации,” RT, 24 Мау 2018, 1:18:26 video. 
53. "Информационное неравенство: как сбалансировать информационную картину мира," St. Petersburg International Economic Forum 2018, 24 May 2018.

54. See, for example, Ben Nimmo, "Failures and Adaptions: Kremlin Propaganda in Finland and Sweden," Foreign Policy Centre, 21 March 2017. 


\title{
Prescribing an American Grand Strategy for the Era of Renewed Great Power Competition
}

\author{
Kashish Parpiani
}

\begin{abstract}
Donald J. Trump's declaration of the reemergence of "great power competition" comes at a pivotal juncture in American history. The Trump administration has borne traits of activist grand strategies toward preserving American primacy with the announced great power competition against China and Russia. This article prescribes a tempered approach for America to pursue its primacy while also addressing the pitfalls of the current system, which counterintuitively accentuate Russian and Chinese insecurity to feed their revisionist approach to the liberal order. The United States must sustain its military edge and challenge Chinese and Russian transgressions, but it must also reform institutions, recalibrate partnerships, and reinstate credibility of the liberal order.
\end{abstract}

Keywords: United States, China, Russia, great power competition, liberal internationalism, grand strategy

I $\mathrm{n}$ the post-Cold War world, the United States has largely pursued liberal internationalism as its grand strategy. Theoretically, it features along the activist former half of the primacy, liberal internationalism, selective engage-

Kashish Parpiani is a research fellow at the Observer Research Foundation (ORF) in Mumbai, India. His research interests include U.S. grand strategy, U.S. civil-military relations, and U.S. foreign policy in the Indo-Pacific. Parpani holds postgraduate degrees in international relations from the S. Rajaratnam School of International Studies, Singapore, and in U.S. foreign policy from the University of Warwick in Coventry, UK. He has published with the Institute for National Security Studies in Tel Aviv, Israel; the Centre on Asia and Globalization in Singapore; the Times of Israel; and the Rising Powers in Global Governance project in Istanbul, Turkey. He has presented papers at international conferences organized by Shanghai University and the International Studies Association. 
ment, and restraint spectrum of grand strategy options. The United States has pursued an expansive conception of interests abroad, prioritized unparalleled U.S. military primacy, advocated for the spread of liberal Wilsonian values (i.e., encouraging foreign nations to adopt liberal democratic fundamentals for socio-political organization of their societies), and spearheaded the postwar institutions that champion free market economics.

However, the liberal internationalist outlook under presidents William J. "Bill" Clinton, George W. Bush, and Barack H. Obama led to expansive and costly military adventures, spurring a decline in its currency as the standard preset of U.S. security and foreign policy. The abhorrence to American activism has only culminated with the rise of conservative nationalism. In many ways, the Donald J. Trump administration's foreign policy has paid heed to the sentiment against U.S. activism abroad that resonates with the less activist conceptions of grand strategy. However, in view of its announced reemergence of great power competition against China and Russia, it has borne some traits of activist grand strategies. A recent case in point being the Trump administration's push for an increase to the U.S. defense budget by more than $\$ 50$ billion.

This article probes a resultant American grand strategy to address the dichotomy posed by a decline in the currency of liberal internationalism and rising Chinese and Russian challenges to the liberal order. The article prescribes an approach that requires reviewing Chinese and Russian revisionist actions as stemming from their insecurity with the current order- to be discussed in subsequent sections. Hence, the article advocates for the United States to pursue its primacy, while also focusing on reforming institutions, recalibrating partnerships, and reinstating credibility of the U.S.-led order.

\section{American Grand Strategies in the Post-Cold War World}

Defined as the "highest form of statecraft . . the intellectual architecture that lends structure to foreign policy," grand strategy has heavily featured in American foreign and security policy discourse. ${ }^{1}$ The reasons for this are primarily two reinforcing factors. First, the United States - through the Cold War and especially in the post-Cold World era-has remained a prominent power. The same has been true not only in terms of its continued economic and military primacy but also America's soft power influence capturing the imagination of successive generations across the globe. This outsized influence has translated into the United States also honing expansive interests-evidenced by its unparalleled power projection capabilities and stewardship of global institutions that comprise the liberal world order. Hence, given its expansive role, American foreign policy has been undergirded with a certain sense of policy foresight and prioritization of threats and interests.

Second, the United States has a strong domestic political culture of rigor- 
ous debate on the country's role in the world. Partly informed by the aforementioned factor of expansive interests, the domestic political culture also stems from a wide subscription to the idea of American Exceptionalism. Often defined as the belief that the United States "has a moral obligation to take a leadership role in world affairs," nearly two-thirds of the American populace are reported to endorse that belief. ${ }^{2}$ Politically, this has meant the institutionalization of the need to have an informed discourse on the matter. For instance, the Goldwater-Nichols Department of Defense Reorganization Act of 1986 stipulates that the executive branch must regularly submit a report to the U.S. Congressand the American public by that extension-on its National Security Strategy (NSS). ${ }^{3}$ Although, over the years, administrations have reduced the frequency of this - from annually to once every term - the NSS has proven to be an effective tool by which one can ascertain the guiding principles behind an administration's foreign and security policy.

As a result, much of the academic pedagogy on grand strategy has also been America-centric. Scholars often cite prominent guiding principles to U.S. foreign policy, such as the policy of containment articulated by George F. Kennan in Foreign Affairs in 1947-as manifestations of American grand strategy. ${ }^{4}$ However, during the ensuing years, four theoretic conceptions of U.S. grand strategy have emerged as dominant in its international relations discourse: primacy, liberal internationalism, selective engagement, and restraint. The four represent a scale of sorts on the degree of intensity of American activism abroad.

The theoretic conception of primacy means the United States "accepts its dominance and seeks to maintain it" and often advocates the "use of military force to achieve policy goals," stemming from an "extremely broad conception of U.S. interests." Liberal internationalism also construes U.S. interests in broad terms but emphasizes sustaining the persisting international system via the spread of democracies and market economies. ${ }^{6}$

From a security standpoint, some scholars also deem it as cooperative security - purporting the furtherance of multilateral security institutions (e.g., the North Atlantic Treaty Organization) or multiple bilateral security arrangements (e.g., the "hub and spokes" alliance network in the Asia-Pacific) that have the United States at its core. ${ }^{7}$ Selective engagement, however, underscores a limited scope of U.S. interests with its central concern being to prevent "wars among the world's major industrial and military powers on the scale of the world wars." ${ }^{8}$ Last, restraint underscores the imperatives of clear articulation of American interests, stemming from a Realpolitik understanding of the United States lacking "the need, the capability, and the mandate to manage global security."

Given international relations' multifaceted, dynamic nature, successive U.S. administrations' foreign policies hardly fit entirely into one of the discussed variations. The alternatives simply serve the theoretic function of according a 
degree of parsimony to analyze U.S. foreign policy. However, post-Cold War U.S. foreign policy reflects a dominance of activist grand strategies-chiefly liberal internationalism, due to the enduring tenets of American international relations: sustaining unparalleled U.S. military primacy, pursuing the spread of liberal democratic values, and spearheading the institutions that comprise the liberal world order.

A barometer for underscoring the relevance of greater U.S. activism on the policy level is the pertinence of so-called "domino theories" in U.S. foreign and security policy discourse. Domino theories are said to string together a sequence of "individually imaginable, but collectively implausible, major events, to generate an ultimate threat to the United States and then argue backward to the extreme importance of using military power to stop the fall of the first domino." ${ }^{10}$ The influence of such a line of argument that warrants U.S. action-mostly militaristic, was evident in the Clinton administration's advocacy of American intervention in Sub-Saharan Africa and Eastern Europe. ThenSecretary of State Madeleine Albright notably rationalized intervention in those distant conflicts as not fitting "neatly into any national security framework but which, if left unattended could erode the foundation of freedom and threaten world peace." ${ }^{11}$ Similarly, in the George W. Bush administration's advocacy for intervening in Iraq, the underlying rationale for the Global War on Terrorism was construed as the United States acting against "emerging threats before they are fully formed . . . [and] to extend the benefits of freedom across the globe."12 Subsequently, although having campaigned against military adventurism, the Obama administration militarily intervened in Libya stemming from a conviction "that a failure to act in Libya would have carried a far greater price for America." 13

The bungling outcome-in terms of casualties and treasure- of these interventions aside, the result has been a downturn in the currency of liberal internationalism and U.S. activism at large.

\section{Decline of Liberal Internationalism and Reemergence of Great Power Competition}

The decline in support for a liberal internationalist outlook has been a slow development in the post-Cold War U.S. polity. At the end of the Cold War, commentators often touted the coming of America's "unipolar moment." ${ }^{14}$ U.S. activism abroad came to be seen at the core of "a new world order, where brutality will go unrewarded and aggression will meet collective resistance." 15 Thereafter, the template was set with no peer competitor on the horizon: America can "be safe only in an Open Door world-a world shaped by America's liberal ideology." 16

Under this rubric, an American exceptionalism-induced characterization of 
U.S. activism abroad emerged. For instance, in dampening allegations of American hegemonic excesses, U.S. security and foreign policy discourse came to be dominated with the view of the international environment being "far more likely to enjoy peace under a single hegemon," and that the United States runs "a uniquely benign imperium" owing to its promotion of liberal democratic values. ${ }^{17}$

Coupled with rising defense budgets to the average of about $\$ 500$ billion in the immediate post-Cold War timeline (FY 1992-2000 in 2015 US\$ constants), U.S. activism abroad often assumed a militaristic character. Interventions rationalized by "domino theories" led the United States into military engagements in Haiti, Rwanda, Somalia, and the former Yugoslavia. ${ }^{18}$ Following the 11 September 2001 attacks, this inclination grew with the Global War on Terrorism to pursue expansive combat missions in Iraq and Afghanistan and assist local missions in Libya, Yemen, Syria, and Niger. ${ }^{19}$

The resultant war fatigue-with the U.S. effort in Afghanistan surpassing the Vietnam War to become America's longest war, and the loss of more than 6,500 U.S. military personnel (reportedly at least 4,486 in Iraq and 2,385 in Afghanistan) at a cost of nearly $\$ 6$ trillion-perhaps led to 57 percent of Americans in a 2016 Pew Research Center poll to agree with the statement: the United States should "deal with its own problems and let others deal with theirs the best they can." ${ }^{20}$

In addition, the rise in the currency of conservative nationalism has spurred an abhorrence toward U.S. activism abroad. Although calls for a less activist America were always marginally present in the U.S. security and foreign policy community since the end of the Cold War, Trump's "America First" outlook was a first in terms of its resonance in the 2016 presidential election. Thus, culminating with the election victory of Trump, that sentiment against U.S. activism accentuated further with Trump's election rallying points of allied nations shortchanging America either in terms of mounting large trade surpluses with the United States or burdening the United States with overbearing security commitments.

A testament to that are the results of a recent November 2018 Pew Research Center poll on foreign policy priorities, which reflects that younger Americans are increasingly opposed to U.S. commitments abroad. The poll found that young Americans (younger than 30) to be less likely to advocate limiting the influence of Russia and China-only 3 in 10 people concurred. ${ }^{21}$ On reducing U.S. military commitments abroad, more than one-third (34 percent) of young Americans concurred..$^{22}$ Meanwhile, on combating terrorism, only 27 percent of Americans younger than 50 deemed it a top priority. ${ }^{23}$

The Trump administration's foreign policy conduct thus far has reflected some of those apprehensions. On NATO, President Trump has rallied against 
allies' contributions and derided American largesse underwriting foreign nations' security. ${ }^{24}$ On trade imbalances, the Trump administration has sought to disconnect economic ties from security matters and has sought renewed "reciprocal" deals with partner nations. ${ }^{25}$ On the promotion of Wilsonian values, Trump's former secretary of state Rex Tillerson notably called for "divorcing" policy from values. ${ }^{26}$ On liberal internationalists' push for multilateral platforms and institutions, the Trump administration has withdrawn from the Joint Comprehensive Plan of Action (commonly known as the Iran nuclear deal) and even initiated U.S. withdrawal from the United Nations Human Rights Council and the Paris Agreement. ${ }^{27}$

The Trump administration has also attempted to reduce U.S. military commitments. In Afghanistan, Trump initiated negotiations with the Taliban, breaking away from U.S. foreign policy precedent and toward an eventual withdrawal of troops. ${ }^{28}$ In Syria, the Trump administration has not only initiated a troop withdrawal but also left the fate of the Kurds-operational allies of the United States against the Islamic State-in the hands of Turkey. ${ }^{29}$ In Yemen, Trump has continued his predecessor's policy of not actively getting involved on the ground and ramped up support to partner nations such as Saudi Arabiaalbeit with much controversy. ${ }^{30}$

These moves reflect the Trump administration's inclinations toward restraint and/or selective engagement. However, at the same time, the Trump administration has reflected some traits of primacy. For instance, in sustaining America's military's superiority, the Trump administration passed increases to the U.S. defense budget—-topping $\$ 716$ billion in 2019 and nearly $\$ 750$ billion slated for 2020. ${ }^{31}$ In underscoring American imperatives to tackle emerging threats, the Trump administration approved the elevation of the U.S. Cyber Command to a unified combatant command responsible for cyberspace operations. ${ }^{32}$ It also announced the creation of the U.S. Space Command with a "projected manpower" of " 1,450 personnel—390 military officers, 183 enlisted personnel, 827 civilians, and 50 contractors." 33

The rationale behind these Reaganesque "peace through strength" moves toward U.S. military capability and readiness can be further ascertained in Trump's initial NSS. Released in late 2017, it announced the reemergence of "great power competition." In doing so, the NSS identified two competitorsChina and Russia - wanting "to shape a world antithetical to U.S. values and interests." Additionally, the NSS stated that Russia and China are "fielding military capabilities designed to deny America access in times of crisis and to contest our ability to operate freely in critical commercial zones during peacetime. In short, they are contesting our geopolitical advantages and trying to change the international order in their favor." 34

This focus on combating Russian and Chinese challenges to the interna- 
tional order-and U.S. primacy by that extension-stand in contradiction to some of the earlier discussed restraint/selective engagement inclinations. Given the decline in the currency of liberal internationalism and increased opposition to U.S. activism, a renewed approach for American grand strategy is warranted.

\section{Emergent U.S. Grand Strategy-Rethinking Primacy}

An emergent American grand strategy-commensurate with the challenges posed by China and Russia to the liberal world order and the political constraints posed by a decline in the currency of liberal internationalism-must encompass a renewed consideration of Chinese and Russian actions. As the Trump NSS notes, Beijing and Moscow wish to order-or reorder-the current international system in accordance with their interests. ${ }^{35}$ In that sense, they are rightly considered revisionist powers. However, many of their actions also stem from a sense of insecurity—-spurred by the limitations of the current U.S.led order.

Both China and Russia have been beneficiaries of the current system to a certain degree. For instance, since 1990 and its accession into the World Trade Organization in early 2000s, China has lifted more than 800 million people out of poverty-an unprecedented feat in the history of the world. ${ }^{36}$ The Soviet Union underwent a near bloodshed-free dissolution, with its United Nations Security Council veto power and vast nuclear arsenal spread mainly across Ukraine, Belarus, and Kazakhstan, seeing a peaceful transfer in the hands of the Russian Federation. ${ }^{37}$ However, Chinese and Russian insecurity stands accentuated in the face of incommensurate representation in U.S.-led institutions, encircling America-centric security arrangements, and dampened credibility of multilateral approaches to issues of global governance.

Correspondingly, a U.S. grand strategy for the renewed era of great power competition must encompass a pursuit of sustaining its primacy-in terms of rightly calling China out on its unfair trade practices and pushing back against Russian cyber operations into foreign nations' democratic processes. However, in consideration of the discussed decline in support for liberal internationalism and opposition toward excessive U.S. activism abroad, that commensurate grand strategy must refrain from a military-intensive, containment-centric approach toward China and Russia. Instead, in recognition of the conservative internationalists' pertinent observation of the liberal order being the "outer perimeter" of U.S. security, the United States must spur China and Russia's further integration into the order to prevent them from disrupting those institutions that consolidate U.S. primacy. ${ }^{38}$

Their further integration would dampen the counterintuitive effects of a supposed containment approach by not emboldening hardliners in Beijing and Moscow that often cry foul over U.S. hegemony of the liberal order. Addition- 
ally, the discussed precedent of China and Russia being beneficiaries of the order would only temper their revisionist impulses of overturning it. Hence, Washington must seek to consolidate its primacy via reforming institutions, recalibrating partnerships, and reinstating credibility of the U.S.-led order.

\section{Reform Institutions}

In the post-Cold War era, the rise of a multilateral world has witnessed a surge in competing interests. As a result, consensus to issues of global governance have become a rarity. Moreover, the institutions that comprise the liberal order have often been criticized as not representing current realities and balances of power. For instance, consider the voting shares of the International Monetary Fund (IMF) and the World Bank's International Bank for Reconstruction and Development (IBRD). A simple perusal of the figures of P5 countries and India, Germany, and Japan reflects its detachment from the current ordering of percentage share of world gross domestic product (GDP). ${ }^{39}$

However, these institutions have been amenable to reform. For instance, the 2010 Fourteenth General Review of Quotas at the IMF shifted "more than 6 percent of quota shares from over-represented to underrepresented member countries" but failed to accord rights commensurate with the status of member states' share of world GDP. The absence of much-needed reforms to these

Table 1.1. Representation in U.S.-led institutions of major powers relative to global economic share

\begin{tabular}{lccc}
\hline Country & $\begin{array}{c}\text { Percentage share of } \\
\text { world GDP (PPP) }\end{array}$ & $\begin{array}{c}\text { Percentage share of } \\
\text { IMF voting rights }\end{array}$ & $\begin{array}{c}\text { Percentage share } \\
\text { of World Bank } \\
\text { IBRD voting rights }\end{array}$ \\
\hline China & 19.24 & 6.09 & 4.37 \\
United States & 15.03 & 16.52 & 15.68 \\
India & 8.07 & 2.64 & 3.00 \\
Japan & 4.05 & 6.15 & 7.89 \\
Germany & 3.15 & 5.32 & 3.96 \\
Russia & 3.07 & 2.59 & 2.74 \\
United Kingdom & 2.20 & 4.03 & 3.71 \\
France & 2.15 & 4.03 & 3.71 \\
\hline
\end{tabular}

Sources: "GDP Based on PPP, Share of World: Percent of World," International Monetary Fund, accessed 15 May 2019; "IMF Members' Quotas and Voting Power, and IMF Board of Governors," International Monetary Fund, accessed 15 May 2019; and "International Bank for Reconstruction and Development Subscriptions and Voting Power of Member Countries," World Bank, accessed 15 May 2019. 
U.S.-led institutions perpetuate underrepresented powers to engage in "forumshopping," mounting "a direct challenge to preexisting multilateral institutions" via creating alternate institutions. ${ }^{40}$

China and Russia both have reflected this tendency in terms of setting up the BRICS New Development Bank and the BRICS Contingent Reserve Arrangement. ${ }^{41}$ From the standpoint of furthering its economic footprint, China's One Belt, One Road initiative is also one pertinent example. Furthermore, China and Russia also cofounded, with other Eurasian countries, the Shanghai Cooperation Organisation, which now also happens to include Iran and Afghanistan with observer status. Lastly, China spearheaded the creation of the Asian Infrastructure Investment Bank with India-another underrepresented country-as its second-largest contributor of capital.

This increase in the number of forums not only makes international cooperation on matters of global governance more complex but also undercuts the liberal order, decreasing Washington's influence by extension. ${ }^{42}$ Going forward, the United States must spearhead the reform of these institutions that are the bedrock of the American stewardship of liberal market economics.

\section{Recalibrate Partnerships}

For 165 years of its existence during two centuries, the United States stayed away from partnerships owing to the Jeffersonian dictum of avoiding "entangling alliances." 43 In the post-Second World War period, however, American commitments abroad peaked, stemming from Cold War considerations. Until right before the fall of the Berlin Wall, the United States had 356,000 troops stationed in Europe and 141,000 troops stationed in East Asia to serve as a bulwark against the possibilities of Soviet expansionism and temper historical rivalries of Japan and Germany with their respective regional neighbors. ${ }^{44}$ By 2014, those numbers had dropped by 81 percent and 43 percent, respectively, to leave about 66,000 U.S. troops stationed in Europe (mainly in the United Kingdom, Germany, and Italy) and 81,000 U.S. troops in Asia (primarily in Japan and South Korea). ${ }^{45}$

However, according to a study by Michael Beckley of Tufts University, the United States continues to have entangling defense arrangements under the Organization of American States (OAS); NATO; Australian, New Zealand, United States Security Treaty (ANZUS); bilateral security pacts with allies such as Japan and the Philippines; and some informal defense commitments (e.g., Israel and Taiwan).

In all, U.S. defense commitments persist with about 69 countries that account for around 75 percent of the world's economic output and are home to one-quarter (more than 2 billion people) of the world's population. ${ }^{46}$ These partnerships most definitely strengthen American power and multiply its edge 
Table 1.2. U.S. defense pacts, $1945-2014$

\begin{tabular}{llll}
\hline \multicolumn{1}{c}{ OAS } & \multicolumn{1}{c}{ NATO } & \multicolumn{1}{c}{ ANZUS } & \multicolumn{1}{c}{ Bilateral } \\
\hline Antigua and Barbuda & Albania (2009), & Australia (1951), & Israel (1962), \\
(1981), Argentina & Belgium (1949), Bul- & New Zealand & Japan (1951), \\
(1947), Bahamas & garia (2003), Canada & (1951-86) & Pakistan (1959), \\
(1982) Barbados & (1949), Croatia (2009), & Philippines \\
(1967), Belize (1991), & Czech Republic (1999) & (1951), South \\
Bolivia (1947), Brazil & Denmark (1949), & Korea (1953), \\
(1947), Chile (1947), & Estonia (2003), France & Taiwan (1954) \\
Colombia (1947), & (1949), Greece (1951), & \\
Costa Rica (1947), & Hungary (1999), & \\
Cuba (1948-62, 2009), & Iceland (1949), Italy & \\
Dominica (1979), & (1949), Latvia (2003), & \\
Dominican Repub- & Lithuania (2003), & \\
lic (1947), Ecuador & Luxembourg (1949), & \\
(1947), El Salvador & Netherlands (1949), & \\
(1947), Grenada & Norway (1949), & \\
(1975), Guatema- & Poland (1999), & \\
la (1947), Guyana & Portugal (1949), & \\
(1991), Haiti (1947), & Romania (2003), Slo- & \\
Honduras (1947), Ja- & vakia (2003), Slovenia & \\
maica (1969), Mexico & (2003), Spain (1981), & \\
(1947), Nicaragua & Turkey (1951), United & \\
(1947), Panama & Kingdom (1949), West & \\
(1947), Paraguay & Germany (1955-90), & \\
(1947), Peru (1947), & Germany (1990) & \\
Saint Kitts and Nevis & & \\
(1984), Saint Lucia & & \\
(1979), Saint Vincent & & \\
(1981), Suriname & & \\
(1977), Trinidad and & & \\
Tobago (1967), Uru- & & \\
guay (1947), Venezue- & & \\
la (1947) & & \\
\hline & & \\
\end{tabular}

Note: names accurate as of time of pact.

Source: Compiled in Michael Beckley, "The Myth of Entangling Alliances-Reassessing the Security Risks of U.S. Defense Pacts," International Security 39, no. 4 (Spring 2015): 23, https://doi.org/10.1162/ISEC_a_00197.

in terms of enhanced power projection capabilities of it honing nearly 800 bases and outposts in more than 70 countries around the world. ${ }^{47}$ However, in recent times, these partnerships have also come under fire owing to conservative nationalism's ire against expansive commitments sapping American resources. At the same time, they tend to accentuate Chinese and Russian insecurity.

The post-Cold War eastward expansion of NATO has in large parts emboldened the hardliners in Moscow about its continued existence even years after the end of the Cold War, whereas the U.S. hub and spokes alliance arrangement has spurred the Chinese to pursue antiaccess/area denial (A2/AD) 
capabilities to push back the U.S. presence in China's immediate periphery in the Pacific. ${ }^{48}$ Moreover, the unclear raison d'être of these partnerships in the post-Cold War era has only added to the misperceptions surrounding an American encirclement of Russia and China. Compounded by the reduced frequency of confidence-building mechanisms such as the Russia-NATO Council and China's exclusion from the recent Pacific Rim exercises only accentuates the perception in Moscow and Beijing about an American containment agenda. ${ }^{49}$

Going forward, the United States must recalibrate its justification for its partnerships across Europe and Asia-possibly in the context of counterterrorism missions or humanitarian and disaster relief efforts and enhance confidencebuilding measures to dampen misperceptions of American encirclement. Certainly, the alliances' role as a bulwark against Russian and Chinese expansionism would continue. However, to dampen the persisting ambiguities over their justifications, recalibrating them on the basis of common challenges such as terrorism can be useful.

\section{Reinstate Credibility}

American ambivalence on multilateral solutions to global governance issues has dampened the efficacy of the liberal order and its agenda-setting role. For instance, the U.S. stewardship on human rights issues stands shortchanged due to its nonratification of the Convention on the Elimination of All Forms of Discrimination Against Women and the Convention on the Rights of the Child. $^{50}$

The potency of the liberal order's dictum on nonmilitarization of the high seas is undercut by the U.S. holdout on the United Nations Convention on the Law of the Sea. ${ }^{51}$ In then pressing for the peaceful resolution as per maritime international law of the territorial disputes between China and its neighbors in the South China Sea, U.S. credibility-and the liberal order's efficacy by that extension-stands in question.

Given Russia and China's pivotal role in tackling some of the world's most pressing issues - from North Korea's nuclear brinkmanship to the fate of Syrian president Bashar al-Assad — credibility of the United States becomes central. Instead, recent developments such as American withdrawal from the Iran nuclear deal may have induced cynicism in Moscow and Beijing about cooperation with the United States on common threats and interests. ${ }^{52}$

For instance, consider the case of the negotiations for the Iran nuclear deal. In the run-up to the agreement under the Obama administration, China and Russia supported about four rounds of crippling sanctions against Iran at the United Nations Security Council. Once those sanctions successfully coaxed Iran to the negotiating table, cooperation with those otherwise adversarial nations 
helped in brokering a deal. China was key in breaking an impasse over the Arak heavy water nuclear facility (or IR-40). Beijing jump-started the negotiations by suggesting "a redesign plan to modify the reactor so as to disable its potential for making weapons-grade nuclear materials." ${ }^{53}$

Going forward, a commensurate American grand strategy for the era of renewed great power competition should also encompass cooperation with friends and foes alike toward common challenges of global governance. ${ }^{54}$ The same would not only strengthen the liberal order's efficacy but also reinstate U.S. credibility with adversaries like Beijing and Moscow.

\section{Conclusion}

The Trump administration is on point in announcing the reemergence of "great power competition." Since the end of the Cold War, the United States has faced competition from China and Russia. Although Washington's economic and military primacy remains intact, Beijing and Moscow pose myriad challenges -asymmetric challenges in cyberspace and symmetric via the use of proxies and vassals. Their central challenge, however, is to the post-Second World War liberal order, which conservative internationalists rightly argue forms the outer perimeter of American security.

In envisioning a commensurate grand strategy for an increase in opposition to American engagement abroad, the United States must consolidate its primacy via addressing the pitfalls of the current system, which counterintuitively accentuate Russian and Chinese insecurity that in turn spurs their revisionist approach to the liberal order. This article thus advocates for the United States to sustain its military edge and challenge Chinese and Russian transgressionsunfair trade practices and cyber intrusions into democratic processes. However, it must also reform institutions by increasing unrepresented nations' stakes in the order, recalibrate partnerships by defining the raison d'être of those alliances in terms of common challenges such as combating terrorism and/or humanitarian assistance and disaster relief, and reinstate credibility of the U.S.-led order by upholding precedents of cooperation with friends and foes alike.

\section{Notes}

1. Hal Brands, What Good Is Grand Strategy?: Power and Purpose in American Statecraft from Harry S. Truman to George W. Bush (New York: Cornell University Press, 2014), 1.

2. Stephen Brooks, American Exceptionalism in the Age of Obama (New York: Routledge, 2013), 72.

3. Goldwater-Nichols Department of Defense Reorganization Act of 1986, Pub. L. No. 99-433 (1986).

4. "X" (George F. Kennan), "The Sources of Soviet Conduct," Foreign Affairs, July 1947.

5. Harvey M. Sapolsky et al., U.S. Defense Politics: The Origins of Security Policy (New York: Routledge, 2009), 19. 
6. Sapolsky, U.S. Defense Politics, 19.

7. David Shambaugh, "Asia in Transition: The Evolving Regional Order," Current History 105, no. 690 (2006): 153-59.

8. $\quad$ Sapolsky et al., U.S. Defense Politics, 20.

9. Sapolsky et al., U.S. Defense Politics, 20-21.

10. Barry R. Posen, Restraint: A New Foundation for U.S. Grand Strategy (Ithaca, NY: Cornell University Press, 2014), 3.

11. Madeleine Albright, "Realism and Idealism in American Foreign Policy Today" (commencement address, Harvard University's Kennedy School of Government, 8 June 1994).

12. The National Security Strategy of the United States of America (Washington, DC: White House, 2002).

13. Barack H. Obama, "Remarks by the President in Address to the Nation on Libya" (speech, National Defense University, Washington, DC, 28 March 2011).

14. Charles Krauthammer, "The Unipolar Moment," Foreign Affairs 79, no. 1 (1990).

15. George H. W. Bush, "Annual Message to the Congress on the State of the Union" (speech, before a joint session of Congress in the Chamber of the U.S. House of Representatives, Washington, DC, 29 January 1991).

16. Christopher Layne, The Peace of Illusions: American Grand Strategy from 1940 to the Present (Ithaca, NY: Cornell University Press, 2006), 118.

17. Charles Krauthammer, "The Bush Doctrine," Weekly Standard, 4 June 2001.

18. "Military Expenditure by Country, in Constant (2015) US\$ m., 1988-2016," Stockholm International Peace Research Institute, 2017, accessed 1 May 2019; and Barbara Salazar Torreon and Sofia Plagakis, Instances of Use of United States Armed Forces Abroad, 1798-2018 (Washington, DC: Congressional Research Service, 2019).

19. Instances of Use of United States Armed Forces Abroad.

20. Haley Britzky, “Afghanistan Is by Far America’s Longest War," AXIOS, 8 October 2018; H. A. Goodman, "4,486 American Soldiers Have Died in Iraq. President Obama Is Continuing a Pointless and Deadly Quagmire," Huffington Post, 6 December 2017; and Bruce Drake and Carroll Doherty, "Key Findings on How Americans View the U.S. Role in the World," Pew Research Center, 5 May 2016.

21. "Conflicting Partisan Priorities for U.S. Foreign Policy," Pew Research Center, 29 November 2018.

22. "Conflicting Partisan Priorities for U.S. Foreign Policy."

23. "Conflicting Partisan Priorities for U.S. Foreign Policy."

24. Dartunorro Clark, "Trump Blasts NATO Ahead of European Visit, Accuses Allies of Shortchanging U.S.," NBC News, 10 July 2018.

25. Kashish Parpiani, "India-US Relations under Trump: Guarding Against Transactionalism by Pivoting to the US Legislature," ORF Issue Brief, no. 262 (October 2018).

26. Julian Borger, "Rex Tillerson: 'America First' Means Divorcing Our Policy from Our Values," Guardian, 3 May 2017.

27. Kashish Parpiani, "Trump’s Exemptionalist US Foreign Policy," Times of Israel, 15 July 2018.

28. Taimoor Shah and Rod Nordland, "U.S. Diplomats Held Face-to-Face Talks with Taliban, Insurgents Say," New York Times, 28 July 2018.

29. Dorian Jones, "Trump's Decision to Withdraw from Syria Is Triumph for Erdogan," Voice of America, 7 October 2019.

30. "Yemen War: Trump Vetoes Bill to End US Support for Saudi-led Coalition," BBC, 17 April 2019.

31. Ryan Browne, “Trump Administration to Propose $\$ 750$ Billion Military Budget Next Week," CNN, 10 March 2019.

32. "U.S. Cyber Command History," U.S. Cyber Command, accessed 14 May 2019.

33. "6 Military Bases Identified for US Space Command," Economic Times, 6 April 2019.

34. The National Security Strategy of the United States of America (Washington, DC: White House, 2017), hereafter 2017 NSS. 
35. 2017 NSS.

36. "China Lifting 800 Million People Out of Poverty Is Historic: World Bank," Business Standard, 13 October 2017.

37. David S. Yost, "The Budapest Memorandum and the Russia-Ukraine Crisis," War on the Rocks (blog), 10 June 2015.

38. Paul D. Miller, American Power and Liberal Order: A Conservative Internationalist Grand Strategy (Washington DC: Georgetown University Press, 2018); and Ted Osius, "Legacy of the Clinton-Gore Administration's China Policy," Asian Affairs 28, no. 3 (2001): 125-26, https://doi.org/10.1080/00927670109601490.

39. P5 refers to the five countries on the original United Nations Security Council with veto-wielding powers: the United States, the United Kingdom, France, China, and Russia.

40. "IMF Quotas," the International Monetary Fund, 8 March 2019; "Fourteenth General Review of Quotas: The Size of the Fund-Initial Considerations," International Monetary Fund, 12 March 2010; and Daniel W. Drezner, "China Plays the ForumShopping Game," Washington Post, 25 June 2014.

41. BRICS refers to the five major emerging national economies: Brazil, Russia, India, China and South Africa.

42. Alyssa Ayres, "Will India Start Acting Like a Global Power?," Foreign Affairs 96, no. 6 (November/December 2017).

43. Adam Taylor, "Map: The U.S. Is Bound by Treaties to Defend a Quarter of Humanity," Washington Post, 30 May 2015.

44. Miller, American Power and Liberal Order, 264.

45. Miller, American Power and Liberal Order, 264.

46. Taylor, "Map: The U.S. Is Bound by Treaties to Defend a Quarter of Humanity."

47. David Vine, "Where in the World Is the U.S. Military?," Politico Magazine, July/August 2015.

48. Shambaugh, "Asia in Transition."

49. "NATO-Russia Council," North Atlantic Treaty Organization, last updated 9 July 2019; Zhenhua Lu and Robert Delaney, "China Protests Being Kicked Out of US Military Exercise," South China Morning Post (Hong Kong), 24 May 2018; and David Filipov, "Putin Says Russia Planning 'Countermeasures' to NATO Expansion," Washington Post, 21 November 2016.

50. Courtenay R. Conrad and Emily Ritter, "A Trump Moratorium on International Treaties Could Roll Back Human Rights-Here at Home," Washington Post, 1 March 2017.

51. Roncevert Ganan Almond, "U.S. Ratification of the Law of the Sea Convention: Measuring the Raison d'État in the Trump Era," Diplomat, 24 May 2017.

52. "Iran Nuclear Deal: Trump Announces US Withdrawal," BBC, 8 May 2018.

53. Harold Pachios, "Let's Look at China’s Role in the Iran Nuclear Deal," Hill, 21 August 2015.

54. Kashish Parpiani, “Trump’s 'Great Power Competition' and US Credibility,” Observer Research Foundation, 18 May 2018. 


\title{
Competing through Cooperation Leveraging Security Cooperation to Counter Chinese and Russian Influence in Africa
}

\section{Captain Daniel De Wit, U.S. Marine Corps Reserve}

\begin{abstract}
The National Defense Strategy and U.S. strategy for Africa have reprioritized great power competition over the threat of terrorism and other nonstate actors. ${ }^{1}$ However, U.S. security cooperation initiatives in Africa have yet to adjust to this change and continue to focus on developing partner forces capable of defeating terrorist groups and other destabilizing nonstate threats. To leverage security cooperation initiatives to counter Chinese and Russian influence activities, planners at U.S. Africa Command must design them primarily for the message they will send, rather than the capability to be imparted to the partner force. Minor changes to security cooperation programs, including a revised and expanded Ministry of Defense Advisors (MODA) program, increased leveraging of psychological operations capabilities, and engaging more directly with African societies will support this effort.
\end{abstract}

Keywords: Africa, influence, security cooperation, great power competition, China, Russia, U.S. Africa Command, AFRICOM

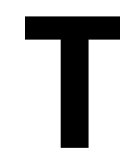

he Department of Defense (DOD) will need to reframe the way it conceives and designs security cooperation efforts with local partners if it is to compete effectively with China and Russia in Africa. The emerging great power competition between the United States, China, and Russia is as central to U.S. interest in this region as it is in Eastern Europe or the Western

Daniel De Wit is an operations support officer with the Defense Intelligence Agency and a PhD candidate in the War Studies Department at King's College London. The views expressed here are the author's alone and do not necessarily reflect the positions of the Defense Intelligence Agency, the U.S. Marine Corps, or the Department of Defense. 
Pacific, and while the new U.S. Africa strategy recognizes this reality, the change is not yet reflected in DOD programs and activities there. ${ }^{2}$

Since a conventional war with Russia or China would be excruciatingly costly for all involved, competition remains below the threshold for armed conflict and primarily takes the form of a contest for influence with key regional actors. In this environment, the capabilities imparted to partner forces through security cooperation programs are less important than the message that cooperative efforts send to observers in the region. The primary objective must be to build trust and lasting influence with key regional governments and militaries, rather than to enhance their capacity for combat operations, which has been the thrust of U.S. security cooperation initiatives to date. ${ }^{3}$ Security cooperation efforts should focus on promoting a narrative about U.S. strategic resilience and the benefits of working with the United States over Russia or China, and de-emphasize small-unit tactical training-the overwhelming focus of such programs since 9/11—except in those cases where such training programs will improve American influence with the recipient governments.

\section{Competing for Influence in the New Global Order}

Great power competition is returning to the international arena at a time when technological and societal trends make major war costlier and less decisive, which in turn drives states to compete below the level of armed conflict. ${ }^{4}$ The increasing cost of weapons systems, decreasing societal tolerance for casualties, and the likelihood that any military activity will be broadcast worldwide via the internet collectively result in increased political risk for any head of state who might seek to use conventional military force. ${ }^{5}$ Furthermore, Russia and China have taken note of America's dominance in conventional military capabilities. Instead of attempting to compete directly against this conventional strength, they have developed techniques to advance their strategic aims, often at the expense of the American strategic position, in ways designed to avoid triggering a conventional military response. ${ }^{6}$ These competitive techniques are often called "gray zone" activities by the U.S. military, but are also known as "hybrid warfare" or "completion below the level of armed conflict." They center on the use of limited force, supported by political or information warfare operations, to undermine adversaries and secure strategic objectives in ways such that responding with conventional force would be ineffective at best and counterproductive at worst. ${ }^{8}$ Russian actions in Ukraine and Chinese efforts to secure its claims in the South China Sea are the most often-cited examples of gray zone competition, but Russian support for the Nicolás Maduro regime in Venezuela and China's efforts to influence politics in Australia and New Zealand indicate that the United States is facing these tactics on a global scale.'

Because gray zone activities are designed to render American advantages in 
conventional force irrelevant or even counterproductive, it is imperative that the United States compete by advancing its own influence efforts around the world. Maintaining superior military capabilities is important, but it will be America's ability to market itself as the partner of choice to strategically important countries that will prove decisive in this contest. ${ }^{10}$ These partnerships will provide the United States with the means to anticipate and disrupt threatening Russian or Chinese advances, ideally without requiring the application of military force. In many cases, it may be as simple as a partner nation choosing a non-Chinese firm for major development contracts or to purchase arms from the United States or France rather than Russia. In every case, the objective should be to prevent America's adversaries from deepening their ability to exert influence over partner nations.

Security cooperation programs will have an important role to play in this effort. While efforts to advance American influence are principally matters for the diplomatic, informational, and economic arms of statecraft, U.S. military programs should be designed so as to support those nonmilitary tools. ${ }^{11}$ Furthermore, inasmuch as every military activity sends a message (intentionally or not), security cooperation efforts must be crafted such that they advance U.S. strategic influence rather than undermining it. ${ }^{12}$

\section{China and Russia in Africa}

China's economic presence in Africa, marked by financing for numerous infrastructure projects and tens of billions of dollars in direct investment, is widespread and highly visible. ${ }^{13}$ This carries significant strategic implications. As

Chinese investment money becomes increasingly critical to the development of numerous African nations, those nations will find themselves less able to resist Chinese efforts to dictate policy decisions. This dynamic is already evident in places such as Malaysia and Sri Lanka, where sovereign states are finding that their debts to Chinese investors hold them hostage to Chinese political maneuvers. ${ }^{14}$ Furthermore, the means by which China selects recipients for its investments and local firms with which to partner is opaque, giving rise to serious concerns about fraud and corruption. This in turn suggests that only an elite few will stand to benefit from engaging with China, whereas whole populations stand to lose through corruption and environmental degradation. ${ }^{15}$

While China's military presence in Africa is far less robust than its economic footprint, it is following a similar upward trajectory. In his first speech to the United Nations (UN) General Assembly in 2015, Chinese president Xi Jinping promised to deliver $\$ 100$ million in free military assistance to the African Union. ${ }^{16}$ Indeed, Chinese arms sales to African nations grew by 55 percent from 2008 to $2017 .{ }^{17}$ In 2017, China also opened the only overseas military base in Djibouti, which will eventually allow the Chinese People's Liberation 
Army (PLA) to project force throughout the Horn of Africa. ${ }^{18}$ Finally, in 2018, the Chinese Ministry of National Defense hosted the inaugural China-Africa Defense and Security Forum, a two-week defense summit in Beijing. Attendees included participants from 50 African nations - out of a total of 54-and the African Union. ${ }^{19}$ These developments suggest that China sees Africa as a vital strategic region and that it is looking to deepen its influence with African militaries to advance both economic and strategic interests.

It is important to view China's increasing economic and military presence in Africa as two halves of a comprehensive engagement strategy. Investments in infrastructure and even human resource development generate greater capacity for partner nations to solve problems and a greater sense within those nations that China is a strong and committed partner. Simultaneously, military engagement and training leads to more professional host-nation forces that are more willing and able to work closely with Chinese security cooperation initiatives. ${ }^{20}$ Collectively, these initiatives deepen Chinese influence and increase the degree to which they become viewed as the "partner of choice" for many African nations. ${ }^{21}$ In this context, it is immaterial that the U.S. presence in Africa is more robust by orders of magnitude, or that U.S. foreign direct investment in Africa exceeds that of China by some $\$ 17$ billion. ${ }^{22}$ The widespread perception in Africa is that the U.S. commitment to its partners there is waning and lacks a cohesive strategy, while China is perceived as the more active and engaged outside power. ${ }^{23}$ This perception has the potential to be self-manifesting: as China is increasingly seen as the partner of choice for African states, African states will increasingly turn to it first, leaving less room for the United States to engage before decisions are made in China's favor. China is becoming the partner of choice by default due to the fact that African leaders see it as a consistent and engaged actor, rather than one that struggles to maintain a coherent focus on African affairs.

This might ultimately mean that the United States could face greater difficulty partnering with African nations on a host of economic or strategic issues. Should U.S. relations with China deteriorate (e.g., over China's efforts to secure its claims on the South China Sea or to forcibly reunify with Taiwan), China could use its increasing influence in Africa as a means to impose costs on the United States without risking escalation in the region under dispute-a technique known as horizontal escalation. ${ }^{24}$ Avoiding this outcome will require more proactive American engagement to maintain and expand its own influence in Africa.

Russia's presence in Africa is far smaller in size and narrower in focus than China's, but it is also far more pernicious. Whereas China is principally an investor in African development and only secondarily engaged with African militaries, Russia is posturing itself as a provider of military and security ser- 
vices to resource-rich African states as well as private firms engaged in resourceextraction operations. ${ }^{25}$ Among the most active Russian actors on the continent is the Wagner Group, a private military company famous for engaging in a major firefight with U.S. forces in Syria and that is now reportedly in 10 countries across Africa. ${ }^{26}$ In exchange for these goods and services, Russia often gains concessions for oil or mineral extraction, as well as an armed contingent on the continent that it can leverage to advance its own aims.

Russian military contractors directly supported Russias gray zone activities in Ukraine and Syria, where they serve to give the Kremlin an ability to influence military developments on the ground while decreasing both the domestic and international political risk inherent in deploying members of the Russian armed forces. ${ }^{27}$ The presence of these companies in Africa gives Russia an ideal spoiler force, which it can use to disrupt U.S. and allied security initiatives in Africa by arming and training militias or other substate forces hostile to U.S. partners. Reports that the Wagner Group may be active in Libya-where most of the country is under the control of Field Marshal Khalifa Haftar, a former Libyan general friendly to Russia—suggest that this may already be happening. ${ }^{28}$

It is noteworthy that the differences in how Russia and China are pursuing their aims in Africa match trends in how they are competing with the United States worldwide. Russia is primarily a disruptive force, using limited aggressive actions to undermine the United States and its allies and generally decrease their ability to respond to security issues around the world. Its tactics are aggressive but not particularly effective at achieving positive aims beyond disrupting U.S.-led international initiatives - witness both Ukraine and Syria, where Russia has prevented the destruction of friendly regimes but only by exhausting their opponents and forcing stalemates. This likely does not trouble Russian president Vladimir Putin, as his primary objective is to disrupt the U.S.-led international order and open space for Russia to play a larger role in the international arena. ${ }^{29}$ Russia's paramilitary forces in Africa are perfectly postured to advance this agenda, as they are strong enough to threaten U.S. and allied interests on the continent, but small enough and far enough removed from the Russian government to leave some ambiguity as to whether they are operating at the Kremlin's direction or for their own economic gain. ${ }^{30}$

China's activities are far subtler and are designed to achieve more positive strategic aims. Through the slow and steady deployment of billions of dollars in direct investment and infrastructure development, China is effectively buying the loyalty of its partners. Chinese military engagements in Africa are designed to protect these investments and the Chinese citizens working to advance them in the field. These activities appear more legitimate and beneficial, and in many cases may not be designed with political influence as the primary intended 
outcome. However, Chinese actions to develop a naval base in Cambodia and to secure access to port facilities in Sri Lanka and the Maldives demonstrate how China can leverage infrastructure investments to expand its global military presence and advance its strategic aims. ${ }^{31}$

These differences in method notwithstanding, China and Russia share an emphasis on undermining the American strategic position in Africa through influence rather than by force of arms. Effectively countering these tactics will require the United States to remain actively engaged with African countries to demonstrate that it is a more effective partner and that it has the staying power to deliver on its promises over the long term. This work is primarily diplomatic in nature, but American security cooperation efforts will have an invaluable role to play due to the universal acknowledgment that for all of China's funds or Russia's willingness to offer up security services to the highest bidder, neither state can individually match the United States in the realm of military capabilities.

\section{Competing through Cooperation}

The United States maintains a robust portfolio of security cooperation programs in Africa, including major regional exercises and task forces supporting regional counterterrorism operations. ${ }^{32}$ However, these programs suffer from a policy-strategy disconnect: while U.S. policy clearly prioritizes the threat posed by great power competition in Africa, security cooperation programs on the ground continue to focus excessively on counterterrorism and counterinsurgency. ${ }^{33}$ For the past decade, the overarching intent of U.S. security cooperation programming was to create capable partner forces who could defeat terrorist groups and other destabilizing nonstate actors in the region so that U.S. forces would not have to intervene directly. ${ }^{34}$ Thus, U.S. security cooperation initiatives have focused on developing military and police forces capable of defeating terrorist attacks, serving in regional peacekeeping missions, and protecting territorial waters and maritime exclusive economic zones from piracy, illegal fishing, and illicit trafficking. Engagements and joint exercises in support of this effort have focused on small-unit tactics and similar core competencies and given comparatively little thought to how these initiatives could be used to counter influence efforts from other outside powers. This was a logical approach to countering globally dispersed terrorist groups without deploying excessive numbers of U.S. troops, but it falls short when the DOD must also engage in a battle for influence with China and Russia. Since both the National Defense Strategy and U.S. Africa strategy prioritize the threat posed by Russian and Chinese influence activities, security cooperation initiatives should likewise emphasize activities that advance U.S. influence in the region.

This means that every engagement that involves partnering of American 
and African forces should be designed principally to advance the narrative that the United States is the partner of choice for African militaries; the actual capabilities that security cooperation engagements seek to impart are of secondary importance. Joint exercises and combined training events should be seen as a venue in which the competition with Russia or China is taking place, regardless of the fact that neither of those countries may be participating in the event itself. While African nations will doubtless continue to seek counterterrorism training and assistance from U.S. forces, United States Africa Command (AFRICOM) should see these programs as a means to demonstrate that the United States maintains superior counterterrorism capabilities to Russia or China and that African partners will stand the best chance of developing their own capable forces by working with the U.S. military.

In some cases, this may mean making the hard choice to provide training or equipment to a partner nation that does not actually require it or that the partner nation may not be able to maintain. Normally, security cooperation officers try to avoid this eventuality at all costs; they make rigorous assessments as to partner force requirements and what capabilities that force can sustain in the long term. ${ }^{35}$ However, security cooperation officers must also recognize that in an era of great power competition, the capabilities of partner forces are themselves less important than how partner forces are engaging with America's adversaries. Thus, security cooperation officers must be willing to consider requests for capabilities that a partner nation wants but that it might not need, recognizing that a failure to do so may mean the nation in question turns to Russia or China for what it wants instead. ${ }^{36}$

In addition to this change in mind-set, AFRICOM should emphasize several structural changes to its security cooperation programs to best position itself to win the fight for influence:

- Revising and expanding the Ministry of Defense Advisors (MODA) program to place field- and flag-rank officers directly into partner ministries of defense, where they can advise foreign military leaders at the uppermost echelons;

- Integrate psychological operations personnel in the security cooperation offices (SCOs) within U.S. embassies in select partner countries;

- Schedule training events that engage whole societies rather than just militaries by, for example, preparing first responders and community organizations to respond to natural disasters.

\section{Revising the MODA Program}

The MODA program places U.S. advisors directly into the ministries of defense of partner governments, advancing U.S. influence through direct, person- 
al contact with senior host-nation military personnel. Senior military officers should staff this program, rather than contractors as is the current practice, because their presence will better convey the importance that the DOD places on relations with its African counterparts. ${ }^{37}$ While the use of contractors allows the Defense Security Cooperation Agency to hire regional experts who possess the requisite language skills and can remain in their posts for longer periods than a usual two to three year military tour allows, it also prevents the United States from capitalizing on the image of an engaged U.S. military that is willing to commit a key resource-qualified senior officers who might otherwise be commanding units or serving critical staff functions - to advance U.S. engagement with the partner military. This perception is the key aspect of such a shift; while contracted MODA personnel undoubtedly bring longevity and cultural familiarity to the table, these are less important to the competition for influence with Russia and China than the perception of U.S. strength and willingness to remain engaged in Africa, which would follow the placement of a uniformed senior officer empowered to represent the DOD directly in the host-nation ministry of defense. The MODA would coordinate their actions with the U.S. ambassador and security cooperation office at the embassy, but they should also be considered as the principal element for engagement with the host-nation defense establishment and empowered with the requisite authorities to act as such.

It is noteworthy that there is ample precedent for the deployment of senior officers in such a capacity. The French Army has maintained a longstanding practice of embedding cooperants within the militaries of its partner countries. ${ }^{38}$ Cooperants are soldiers that train and mentor new senior leaders, build professionalism, and ensure interoperability, all in support of French interests. The French Army has reaped benefits from this arrangement in terms of close relations with partner militaries and freedom of movement for its own forces in the region. There is no reason that the United States cannot expect similar results.

\section{Psychological Operations from the Security Cooperation Office}

The DOD should consider stationing psychological operations (psyops) personnel to the Office of Security Cooperation (OSC) at embassies in key countries overseas. Psyops troops are specifically trained to craft information campaigns and narratives to advance U.S. objectives. ${ }^{39}$ They also are trained to understand how U.S. actions may be perceived by various audiences and to advise unit commanders on how to take these perceptions into account when planning any military action. Placing them in the OSCs will enable the development of security cooperation programs that are purpose built to advance U.S. influence among target audiences overseas.

The OSC is intended to be the primary interface for planning, coordinat- 
ing, and overseeing security cooperation efforts between the United States and partner nations. ${ }^{40}$ As such, they are staffed with U.S. military foreign area officers (FAOs), who are tasked with overseeing foreign military sales, combined training programs, and other joint engagements. ${ }^{41}$ This is very much in keeping with the current U.S. approach toward security cooperation, improving the host nation's ability to manage security problems so that the United States does not need to intervene directly. However, these officers are generally not trained to think about their mission as an aspect of a competition for influence with Russia and China. To balance the focus on specific security cooperation cases with an understanding of the broader strategic competition, embassy OSCs in key locations should host psyops personnel, who can help craft and message security cooperation programs so as to maximize the resulting influence for the United States. Alternatively, DOD may consider adding some psychological operations training to FAO training programs so that all personnel assigned to the OSC have at least a minimal level of knowledge about how to craft security cooperation initiatives to maximize U.S. influence.

Psyops troops are unique in the U.S. military in that they alone are trained to influence foreign populations by developing narratives and delivering them through a variety of media. When properly employed, psyops personnel can sow division within an enemy force, disrupting its cohesion and ultimately sapping its ability to resist. This was most recently evident in the U.S. effort to defeat Joseph Kony's Lord's Resistance Army (LRA) in central Africa. A handful of pysops specialists used targeted messaging to cause mass defections from the LRA, ultimately neutralizing it as a serious threat even though Kony himself was never captured. ${ }^{42}$

While psyops personnel assigned to the OSC will be able to draft and disseminate tailored messages to audiences in the host nation (assuming interagency concurrence), their real utility will be in understanding how routine security cooperation initiatives will be perceived by a variety of audiences, and then planning those initiatives to maximize perceptions in accordance with U.S. interests. If security cooperation planners are to proceed from the understanding that cooperative engagement programs are themselves a means to advance American influence, it follows that personnel trained in strategic messaging should have a hand in crafting these programs. This understanding, when paired with the cultural and linguistic expertise found in foreign area officers, will allow security cooperation initiatives to go beyond enhancing the capabilities of select units and instead advance the narrative that the United States' presence in Africa is a superior alternative to the predatory and transactional relationships that Russia and China have to offer. 


\section{The Whole-of-Society Approach}

The current approach to security cooperation in Africa is heavily weighted toward engagements with military and police units from partner nations. This is natural given the DOD's mission and focus on building local capabilities to counter substate threats. However, it neglects a potential source of competitive advantage that the United States enjoys over Russia or China: positive popular views of the United States in comparison to its competitors. ${ }^{43}$ While China maintains a robust presence, the transactional nature of its business dealings raise concerns about corruption and the benefits of Chinese engagement going to a tiny elite. ${ }^{44}$ Similarly, Russia's mercenary-led engagement on the continent cannot provide benefits to whole populations. The United States should take advantage of this by engaging directly with African people who have no military or government affiliation, particularly during the course of security cooperation engagements with African security forces. The aim should be to advance the narrative that the U.S. presence in Africa can benefit whole populations and that the U.S. military in particular can offer beneficial humanitarian resources that Russia and China simply cannot match.

The U.S. Navy's response to the 2004 Indian Ocean tsunami resulted in an unprecedented increase in goodwill for the United States among a previously skeptical Indonesian population, which in turn resulted in increased counterterrorism cooperation with the Indonesian armed forces. ${ }^{45}$ The U.S. response to the 2014-16 West Africa Ebola outbreak, which eventually totaled more than $\$ 5$ billion in U.S. assistance and hundreds of U.S. military and civilian personnel on the ground, similarly demonstrated American determination to remain engaged in the region as well as the superior resources it can contribute to humanitarian aid or deal with societal problems. ${ }^{46}$

U.S. security cooperation initiatives should seek to proactively achieve a similar effect by engaging directly with local governments and civic groups to provide training in response to natural disasters and other humanitarian crises. U.S. Agency for International Development's Office of U.S. Foreign Disaster Assistance regularly trains foreign partners to prepare for natural disasters, but, at least in Africa, these efforts are generally not connected to DOD exercises, which focus on regional security and peacekeeping. ${ }^{47}$ Closing this gap could pay significant dividends for American influence in the region. U.S. forces training in the region could, for example, spend time training first responders and hospital staff in triage and care procedures for high-casualty events. Such engagements would showcase the U.S. military presence in the region as a positive force for regular civilians and not just governments or militaries. This is a distinct image from the transactional methods pursued by Russia and China that primarily benefit the elites and would help ensure a strong basis of popular support for U.S. engagement in Africa. 


\section{Conclusion}

The most crucial shift necessary for the United States to compete in Africa is one of mind-set: American military leaders engaged on the continent must understand that every action they take contributes in some form to the growing competition with Russia and China. As a result, U.S. security cooperation initiatives must prioritize this competition and seek first and foremost to advance a strategic narrative about U.S. strength and resiliency in the region. The substance of these programs themselves, while important, must be viewed as secondary to the message that implementing them will send to local governments and populations. This may mean, for example, that U.S. tax dollars go toward financing a weapons or equipment purchase for an African military that does not truly need the systems in question if the alternative is that the African military will later purchase it from China or Russia. While any security cooperation officer would normally try to dissuade the partner force from such a purchase, a competitive mind-set might instead mean supporting and even expediting the sale if that is what is necessary to prevent U.S. adversaries advancing their own influence through arms sales instead. While the OSC's explicit mission is to manage arms sales and other security cooperation initiatives as expediently as possible, these activities are normally viewed explicitly in terms of how the receiving nation will benefit from the sale and how its increased capabilities will in turn advance U.S. strategic objectives. Competition with other great powers - especially ones outside the region that do not pose a direct threat to the receiving country - often do not factor into security cooperation plans. This must change, in Africa if not elsewhere, if the United States is to stay ahead of China and Russia's strategic advances.

The other measures recommended here-placing advisors in ministries of defense, deploying psyops personnel to embassy security cooperation offices, and engaging directly with societies instead of only friendly militaries-will all serve as force multipliers, allowing U.S. leaders to shape the environment through security cooperation functions such that it is more amenable to U.S. policy aims and less so to its adversaries. But they can only function in this way if the people sent to fill these roles understand that security cooperation must no longer be purely about making partner nations more capable. It must instead be geared toward advancing U.S. strategic goals vis-à-vis China and Russia or not undertaken at all.

\section{Notes}

1. John R. Bolton, "Remarks by National Security Advisor Ambassador John R. Bolton on the Trump Administration's New Africa Strategy" (speech, Heritage Foundation, Washington, DC, 13 December 2018), hereafter Bolton remarks.

2. Bolton remarks.

3. Gen Thomas D. Waldhauser, 2018 Posture Statement to Congress (13 March 2018) 
(U.S. Africa Command testimony before the House Armed Services Committee and the Senate Armed Services Committee).

4. Charles Cleveland et al., Military Strategy in the 21st Century: People, Connectivity, and Competition (New York: Cambria Press, 2018), 16.

5. Andreas Krieg and Jean-Marc Rickli, "Surrogate Warfare: The Art of War in the 21st Century?," Defence Studies 18, no. 2 (2018): 113-30, https://doi.org/10.1080/14702 436.2018.1429218.

6. Sean McFate, The New Rules of War: Victory in the Age of Durable Disorder (New York: HarperCollins, 2019), 66-67, 105.

7. United States Special Operations Command, white paper, "The Gray Zone," 9 September 2015.

8. Hal Brands, "Paradoxes of the Gray Zone," Foreign Policy Research Institute, 5 February 2016.

9. Antulio J. Echevarria II, Operating in the Gray Zone: An Alternative Paradigm for U.S. Military Strategy (Carlisle, PA: Strategic Studies Institute, U.S. Army War College Press, 2016).

10. Cleveland et al., Military Strategy in the 21st Century, 22.

11. U.S. Army Special Operations Command, white paper, "SOF Support to Political Warfare," 10 March 2015.

12. Joint Concept for Operating in the Information Environment (JCOIE) (Washington, DC: Joint Chiefs of Staff, 2018), 27.

13. Witney Schniedman and Joel Wiegert, "Competing in Africa: China, the European Union, and the United States," Africa in Focus (blog), Brookings, 16 April 2018.

14. "The Perils of China’s 'Debt-Trap Diplomacy'," Economist, 6 September 2018.

15. Jeff Smith, China's Belt and Road Initiative: Strategic Implications and International Opposition (Washington, DC: Heritage Foundation, 2018).

16. Nikhil Sonnad, "Read the Full Text of Xi Jinping's First UN Address," Quartz, 29 September 2015.

17. Kristin Huang, "China’s Arms Sales Rise as It Vies with US for Influence on World Stage," South China Morning Post (Hong Kong), 12 March 2018.

18. Doug Livermore, "On the Horns of a Dilemma-Addressing Chinese Security Engagement in the HOA," Small Wars Journal, 2 November 2018.

19. "China-Africa Defense, Security Forum Opens in Beijing," XinhuaNet, 26 June 2018.

20. Lina Benabdallah, "Chinese Peace and Security Strategies in Africa: Building Capacity Is Building Peace?," African Studies Quarterly 16, nos. 3-4 (December 2016): 17-34.

21. Gaby Galvin, “'America First' May Put Africa Last,” U.S. News \& World Report, 18 July 2017.

22. Amy Copley, "Figures of the Week: African and Global FDI Inflows Weaken in 2017," Africa in Focus (blog), Brookings, 14 June 2018.

23. Reuben Brigety, "A Post-American Africa: The U.S. Is Falling Behind," Foreign Affairs, 28 August 2018.

24. For example, in the wake of the Soviet invasion of Afghanistan, the Ronald W. Reagan administration considered plans to attack Soviet forces stationed in Cuba should the Soviets strike into the Persian Gulf from Afghanistan. See Joshua M. Epstein, "Horizontal Escalation: Sour Notes of a Recurrent Theme," International Security 8, no. 3 (Winter 1983-84): 19-31.

25. "How Russia Is Boosting Its Role in Africa with Weapons, Investment and 'Instructors'," Agence France-Presse, 14 August 2018.

26. Henry Meyer et al., "Putin's Notorious 'Chef' Is Now Meddling Across Africa," Bloomberg, 19 November 2018.

27. Sergey Sukhankin, " 'Continuing War by Other Means': The Case of Wagner, Russia's Premier Private Military Company in the Middle East," Jamestown Foundation, 13 July 2018.

28. Neil Hauer, "Russia's Favorite Mercenaries," Atlantic, 27 August 2018.

29. Kadri Liik, "What Does Russia Want?," European Council on Foreign Relations, 26 May 2017. 
30. Kimberly Marten, "Semi-state Security Actors and Russian Aggression," Lawfare (blog), 8 July 2018.

31. For a review of China's maneuver influence in the Maldives, see Lee Jeong-ho, "Why Are China and India So Interested in the Maldives?," South China Morning Post (Hong Kong), 25 September 2018. For a similar review pertaining to China and Sri Lanka, see Maria Abi-Habib, "How China Got Sri Lanka to Cough Up a Port," New York Times, 25 June 2018. For information on China’s base development in Cambodia, see Jeremy Page et al., "Deal for Naval Outpost in Cambodia Furthers China's Quest for Military Network," Wall Street Journal, 22 July 2019.

32. Waldhauser, 2018 Posture Statement to Congress.

33. Alice Hunt Friend and Ariel Fanger, "U.S. National Security and Defense Goals in Africa: A Curious Disconnect," Center for Strategic and International Studies, 13 February 2018.

34. Kevin Baron, "Don't Expect Obama to Budge on His High Bar for Intervention," Defense One, 7 July 2015.

35. The DOD manual for security cooperation stipulates that the country team at the U.S. embassy in the requesting country assess how arms sales and other programs will impact U.S. strategic interests, the capabilities of the receiving country's military, and the receiving country's ability to effectively maintain and employ the equipment provided. See The Management of Security Cooperation, edition 39.0 (Wright-Patterson Air Force Base, OH: Defense Institute of Security Cooperation Studies, 2019), 5-7.

36. For example, Egypt is currently purchasing Russian advanced fighter jets, despite the fact that it faces no major conventional threats, due to the U.S. government canceling some arms sales after the Egyptian military ousted President Mohamed Morsi in 2013. See "Egypt Goes on an Arms Spending Spree," Stratfor, 9 October 2018.

37. George M. Dryden, "The Ministry of Defense Advisors Training Program: Preparing Advisors to Have Strategic Impact," Small Wars Journal, 26 September 2018.

38. Jennifer D. P. Moroney et al., "France's Approach to Security Cooperation," in Lessons from U.S. Allies in Security Cooperation with Third Countries: The Cases of Australia, France, and the United Kingdom (Santa Monica, CA: Rand, 2011), 36-37.

39. Maj David Cowan, USA, and Maj Chaveso Cook, USA, "What's in a Name?: Psychological Operations versus Military Information Support Operations and an Analysis of Organizational Change," Military Review, March 2018.

40. "Security Cooperation Organizations Overseas," in The Management of Security Cooperation (Wright-Patterson Air Force Base, OH: Defense Institute of Security Cooperation Studies, 2018), 4-1.

41. "Security Cooperation Organizations Overseas," 4-9.

42. Patrick Tucker, "How US Special Operators Helped Take Down Joseph Kony's Army with Tailored Messages," Defense One, 17 October 2017.

43. A 2015 study by the Pew Research Center found that across Africa, the United States had a 9 percent higher approval rating than China (79-70 percent); U.S. technological achievements and ways of doing business were particularly favored. See Richard Wike, "5 Charts of America's (Very Positive) Image in Africa," Pew Research Center, 23 July 2015. In 2018, Pew also conducted a survey of global attitudes on U.S. versus Chinese leadership, which included surveys in Nigeria and South Africa. In both countries, the U.S. approval rating was higher by, on average, 13 percent. See Kristin Bialik, "How the World Views the U.S. and Its President in 9 Charts," Pew Research Center, 9 October 2018.

44. Wes Martin, "Corruption Is China's Friend in Its Quest to Dominate Africa," National Interest, 13 September 2018.

45. Bruce A. Elleman, Waves of Hope: The U.S. Navy's Response to the Tsunami in Northern Indonesia (Newport, RI: Naval War College Press, 2007), 101.

46. Jennifer Kates et al., "The U.S. Response to Ebola: Status of the FY2015 Emergency Ebola Appropriation," Henry J. Kaiser Family Foundation, 11 December 2015.

47. "Exercises," United States Africa Command, accessed 27 July 2019. 


\title{
U.S. Strategic Interests in the Arctic A Proposed Department of Defense Approach
}

\author{
Major Timothy W. Chess, U.S. Army
}

\begin{abstract}
In the wake of climate change, the Arctic is witnessing a level of transportation and access to resources unprecedented in modern history. Since the end of the Cold War, the Arctic has been a region of cooperation among both Arctic and non-Arctic nations. However, as the region witnesses an increased level of activity and race for resources, so too will the level of stress increase the strain on cooperation and diplomatic relationships, especially those between Russia and the West. The United States has been slowly preparing for an increased presence in the Arctic region, publishing its first strategic security document earlier this decade. The progress of the Department of Defense (DOD) still pales in comparison to current competitors' efforts in the Arctic. To protect national interests in the Arctic, the DOD requires a new plan of action focused on increased levels of cooperation, force, equipment, and infrastructure improvements, as well as revising the department's Unified Command Plan. This plan should provide a strategic message to allies, partners, and adversaries alike that the United States is prepared to operate in the Arctic.
\end{abstract}

Keywords: Arctic, Department of Defense, DOD, Russia, China, North Atlantic Treaty Organization, NATO, cooperation, Unified Command Plan, U.S. European Command

he Arctic region came into its own strategic significance during the Cold
War. It offered the shortest distance for intercontinental ballistic missiles
and long-range bombers between the Soviet Union and the continental

Timothy W. Chess is a graduate of the United States Military Academy and holds a master's of engineering from the University of Texas at Austin. He most recently served as a U.S. Army fellow at the George C. Marshall European Center for Security Studies in Garmisch, Germany. 
United States. The region witnessed an extensive level of militarization from both sides, including air and naval bases, radar stations, submarine activity, military exercises, and nuclear testing. ${ }^{1}$ The Arctic still maintains its strategic importance for not only the United States, Russia, and other Arctic states but also for China, a self-proclaimed near Arctic nation. ${ }^{2}$ No one should advocate for a return to the high level of tension between the United States and Russia that characterized the latter half of the twentieth century, but recent events have stressed a complicated relationship: North Atlantic Treaty Organization (NATO) expansion into Eastern Europe, Russian interference in U.S. and European elections, Russia's illegal annexation of Ukrainian territory, U.S. and Russian friction in Syria, and recent cyberattacks by Russia. Due to these Russian actions and an increasingly powerful China, the 2017 U.S. National Security Strategy focused on a return to great power competition. This competition could lead to conflict with Russia or China, especially as their military capabilities are estimated to peak around $2030 .^{3}$

Recent issues aside, one region where countries from North America, Europe, and Asia have demonstrated a willingness to cooperate is the Arctic. Through a multitude of forums, primarily the Arctic Council, the eight Arctic nations have agreed on search and rescue coordination, oil-spill response preparations, scientific cooperation, a fishery agreement, and boundary dispute settlements. ${ }^{4}$ The one issue not addressed by numerous Arctic forums is security, which continues to remain in the background of other Arctic-related issues.

However, as the Arctic becomes more accessible due to climate change, cooperation among Arctic nations could falter. The continued ice melt will expose more consistent shipping routes and increase opportunities for resource extraction, commercial traffic, and tourism. As other non-Arctic countries seek access, the likelihood for economic, military, and resource competition will increase. In addition, the Arctic remains a geographic location where NATO member states and Russia intersect, creating an area of potential strategic spillover, where disagreements and tensions in Europe and the Middle East could manifest. ${ }^{5}$ Cooperation among allied Arctic nations will only increase in importance going forward, especially in the face of an aggressive Russia and an increasingly ambitious China.

During this decade, Russia has increased its efforts to revitalize and rebuild its military with a special focus on Arctic capabilities. In 2014, Russia deemed the Arctic region a high enough strategic priority to establish a Northern Joint Strategic Command, specifically oriented on the Russian Arctic in combination with its Northern Fleet. ${ }^{6}$ In addition, they have upgraded communications and satellite equipment, military infrastructure, established specific Arctic infantry units, and continued to increase the lethality and size of their naval combatant fleet. ${ }^{7}$ The Russian military has also focused on comprehensive reform programs 
with completion windows between the 2020s and 2030s to increase professionalization, modernize equipment, and increase readiness with the goal of a smaller and more capable military formation. ${ }^{8}$ Focusing on military reforms will enable the Russian leadership to protect national interests and maintain domestic control as their oil- and gas-dependent economy continues its downward trend. ${ }^{9}$ The Russian military is taking the necessary steps toward protecting their country's interests in the Arctic, whereas the United States, as stated by the secretary of the Army, has "mortgaged its readiness" during the last 18 years. ${ }^{10}$ The current U.S. Northern Command (NORTHCOM) commander, General Terrence J. O'Shaughnessy, has also stressed that the United States is not nearly on par with Russia to execute and sustain operations in the Arctic, pointing directly to the lack of infrastructure and presence. ${ }^{11}$

China's ambitions in the Arctic reflect their continued pursuit of global economic dominance and a desire to reshape the world order. Unlike Russia's approach, in part because they are not a littoral Arctic state and currently lack an Arctic military presence, China is pursuing a strategy of influence and investments to gain access to both transpolar waterways and the multitude of resources estimated to exist in the Arctic region. They are creating a fleet of nuclear-powered icebreakers, in addition to their six gas-powered vessels, and have invested considerably in European Arctic infrastructure projects. ${ }^{12}$ As China moves forward to solidify their positioning in the Arctic, they could pursue stronger economic ties with Russia; Russia provides the access and land bases and China provides financial backing for a weakened economy. The U.S. secretary of state, Mike Pompeo, recently acknowledged the possibility of the Chinese using the cover of scientific research in the Arctic as a way of increasing their military presence. ${ }^{13}$

The DOD is duty bound to prepare for the future and defend U.S. national interests in the Arctic. These interests include strategic deterrence, freedom of navigation, and the protection of sovereign territory and rights. ${ }^{14}$ Since the end of the Cold War, the DOD has focused its efforts in other theaters of operation, combating terrorism and focusing less on militarily defending territory, resources, and lines of communications that are vital to the nation. However, the potential for future conflict in the Arctic requires the DOD reexamine its current strategy and posture. A proposed DOD approach to protecting national interests in the Arctic requires a focus on increased cooperation and coordination, preparing forces, equipment, and infrastructure for the Arctic and modifying the Unified Command Plan. ${ }^{15}$

\section{Increased Military-to-Military Cooperation and Coordination}

A cornerstone of the DOD's approach in the Arctic should focus on an in- 
creased cooperation between NATO members and partner countries. A way of increasing cooperation is through additional military training and readiness exercises. NATO conducts on average about one to two exercises in the Arctic region per year, accounting for less than 10 percent of its annual exercise total. ${ }^{16}$ While the limited number of exercises in the Arctic region does not indicate a lack of military cooperation among Arctic states, it is an indicator that NATO's focus is elsewhere. The United States, NATO-allied militaries in the Arctic (Canada, Norway, and Denmark), and NATO's Enhanced Opportunities Partners (Sweden and Finland) would benefit from additional exercises and training opportunities to build interoperability, increase Arctic war fighting expertise, and demonstrate their resolve along NATO's northern boundary. The DOD could approach this cooperation in a multitude of ways: bilaterally with Arctic countries, especially Canada and Denmark due to colocation in North America, and as part of additional Arctic-centric NATO exercises, as demonstrated during Trident Juncture 2018.

The United States, and other Arctic states as a whole, also stand to benefit from increased military coordination with Russia on specific issues, such as monitoring commercial use of trade routes, enforcing adherence to exclusive economic zones, combining search and rescue capabilities, and providing broad military support to civil authorities. ${ }^{17}$ Nonmilitary cooperation with Russia in the Arctic is already established through various organizations; however, since the 2014 invasion of Ukraine, security dialogue has stalled across several forums, including the Arctic Security Forces Roundtable. The 2019 U.S. National Defense Authorization Act authorizes U.S. forces to coordinate, not cooperate, with the Russian military for operational deconfliction. ${ }^{18} \mathrm{With}$ the current authorization act in mind, the DOD could request approval for the establishment of a formal coordination apparatus at the U.S. combatant command-Russian Northern Joint Strategic Command level to demonstrate capacity and resolve in the Arctic while preventing unintended escalation. Even though a coordination mechanism at the military level appears difficult under the current circumstances, this should still remain a long-term objective for the DOD.

\section{Forces, Equipment, and Infrastructure to Support Operations}

To protect U.S. interests in the Arctic, the DOD should focus on preparing forces, equipment, and infrastructure. Currently, the DOD has minimal dedicated, trained, and equipped forces aligned and positioned forward to conduct operations in the Arctic region. The ground forces are limited to less than one U.S. division, with two infantry brigades from the Army stationed in Alaska and not fully dedicated to Arctic operations under the U.S. Indo-Pacific Command (INDOPACOM) and a rotational U.S. Marine infantry battalion pres- 
ence in Norway under U.S. European Command (EUCOM). ${ }^{19}$ In addition, four total combined active duty and Reserve Air Force fighter squadrons are stationed in Alaska. ${ }^{20}$ The Navy's Arctic presence consists of only aerial and subsurface patrols. ${ }^{21}$ If the Army forces in Alaska are deployed in support of other worldwide contingency operations, as they often have during the last 18 years, then there are no other Arctic-trained forces to fill the gap. The DOD does not currently maintain a dedicated and trained Arctic force capable of projection 365 days a year. In addition, brigade-size organizations and larger do not currently rotate through Alaska or northern Europe as they do in central Europe and South Korea to train for operations under Arctic conditions. The lack of trained Arctic forces limits the DOD and its combatant commands' ability to respond to threats in the Arctic.

Part of the DOD's approach in the Arctic should hinge on maintaining a dedicated, capable, and ready force to support operations and deter aggression in both the North American and European Arctic. The military could accomplish this through the use of operational plans with designated forces, both for the North American and the European Arctic, assigned to NORTHCOM and EUCOM. The plans could utilize a 12- to 24-month period when units from across the Services, including the U.S. Special Operations Command (SOCOM), are designated to respond to security threats in support of both combatant commands. This approach provides two benefits to the DOD: one, it offers NORTHCOM and EUCOM commanders an allocated joint force package with a specified purpose without taxing their currently assigned forces; and two, as units rotate through this "Arctic Reaction Force," they are able to train under Arctic conditions and increase their warfighting proficiency in a unique environment. In addition, this Arctic warfighting knowledge and expertise would spread across the Services as different units and personnel conduct rotations.

The DOD's approach to preparation for Arctic operations should also include key dual-purpose infrastructure and equipment programs necessary to execute and sustain future operations. Numerous military leaders, academics, think tanks, and governmental agencies have previously identified the lack of infrastructure and operational equipment in the U.S. Arctic: there is currently no deepwater port along the U.S. Arctic coast capable of supporting U.S. Navy cruisers, carriers, and destroyers; minimal Alaskan infrastructure and communications capabilities; and only one heavy, active U.S. icebreaker with a potential three- to six-year gap without an operational icebreaker in the near future. ${ }^{22}$ When compared to the reconstitution efforts by the Russian military and capability improvements by the Chinese, the United States falls drastically short.

Going forward, the DOD, along with other relevant government agencies, should work to bridge these capability gaps to enable better support for the 
forward projection of forces. Infrastructure improvements in Alaska would also better prepare the U.S. Arctic for future increases in economic and transportation activity throughout the region. In the near term, the military should establish forward staging bases. These staging bases would not necessarily require full-time operation but would serve as warm bases to support training, exercises, and operations when needed in the Arctic environment. For example, the U.S. Navy is currently modernizing a portion of the mothballed Naval Air Station Keflavik, Iceland, to support Boeing P-8A Poseidon maritime patrol/ submarine-hunting aircraft and visiting U.S. Navy vessels. ${ }^{23}$ Arctic staging bases would also assist in the reinforcement and protection of the transatlantic sea lines of communication and counter potential adversary antiaccess/area denial (A2/AD) operations. Protecting U.S. national interests and demonstrating resolve in the Arctic requires the DOD to establish a long-term and executable plan for a dedicated Arctic force, procurement of necessary equipment, and investment in key infrastructure.

\section{Updating the Unified Command Plan}

The current DOD Unified Command Plan addresses the Arctic area in three separate facets. First, the plan splits the area between EUCOM and NORTHCOM in half, with the North Pole falling within the NORTHCOM area of operations. Second, the Unified Command Plan designates NORTHCOM as the lead combatant command for Arctic capability advocacy. Third, the plan states that both EUCOM and NORTHCOM share combatant command responsibility for the Arctic region. ${ }^{24}$ NORTHCOM's boundary is also at certain locations closer to Europe and Asia than to North America, and with their focus on homeland defense, potential Russian aggression in the Arctic could exacerbate ambiguity of responsibility between the two commands. To provide more flexibility for EUCOM to deter threats and support steady state operations, the DOD should shift the NORTHCOM boundary closer to the North American continent, potentially adhering to the 200 nautical mile economic exclusion zone. The boundary shift would also provide EUCOM more maneuver space on the European side of the Arctic Ocean to conduct operations, cooperate with allies and partners, and prevent crises.

In addition to shifting the current combatant command boundary, EUCOM should be designated the lead overall command for Arctic operations, with NORTHCOM maintaining sole responsibility for the North American Arctic. The highest Arctic population density and the fastest ice melt rate of the Arctic region both reside on the European side of the Arctic. The European Arctic is also the most likely side for future conflict and potential security issues, considering the complex and often tense relationship between Western Europe, NATO, and Russia. Six of the eight Arctic 
countries also fall within the EUCOM area of responsibility. In addition, these European Arctic nations already possess a strong relationship with the EUCOM commander, staff, and Service components through combined exercises, security force assistance, exchanges, and coordination. ${ }^{25}$ Considering the potential for strategic spillover in the Arctic, EUCOM also possesses the experience and expertise in dealing with Russian aggression in Europe. ${ }^{26}$ NORTHCOM lacks this experience and historical connections to the European Arctic nations. ${ }^{27}$ All Arctic countries also share a connection to NATO; the United States, Canada, Norway, Iceland, and Denmark are all members of NATO with Finland, Sweden, and even Russia all serving as partners of various degrees. ${ }^{28}$ As the commander of EUCOM also serves as the Supreme Allied Commander for NATO's military forces, Arctic security issues neatly fit under both EUCOM and NATO's portfolios.

The simplicity of a single lead combatant command is vital for the future Arctic landscape, where non-Arctic actors will push for increased access to potentially vast resources. EUCOM as the lead would provide a single point of coordination for the INDOPACOM commander and staff, focusing primarily on China. EUCOM as the lead combatant command also provides other geographic combatant commands with a single point of contact as well. With China increasing their posture for Arctic operations and investing heavily in Arctic states, such as Denmark, Iceland, Norway, and Finland, constant monitoring will require significant intelligence sharing and cooperation between the two geographic combatant commands. Designating EUCOM as the lead command for the Arctic provides a single coordination point, providing simplicity for the DOD's efforts in the region.

Finally, when considering training and joint-coalition exercises in the Arctic, they are most likely to take place within the EUCOM and NATO footprint with a focus on Russian deterrence. As demonstrated during Trident Juncture, these exercises have historically involved Norway, Sweden, and Finland. In addition, EUCOM can access additional funds outside its normal combatant command budget, through the European Deterrence Initiative, to spend on exercises, training, infrastructure, and prepositioning within the European Arctic. ${ }^{29}$ Designating EUCOM as the lead combatant command for the Arctic and shifting the current boundary will enable one combatant command to focus on potential threats in the Arctic — a single command that already cooperates with other Arctic allies and is closely aligned with NATO.

\section{Conclusions}

The Arctic transportation waterways are projected to become nearly ice free during the summer months by the 2030s and hence more accessible for commercial activity, transportation, tourism, and military forces. ${ }^{30}$ The DOD can ill 
afford to be under prepared to potentially face a resurgent Russian threat, whose forces can execute and sustain operations in the Arctic at a higher level than the United States and its allies. In addition, China is increasing their capabilities and influence in the Arctic region as they continue to pursue their own "Polar Silk Road" strategy and further cement their partnership with Russia.

The Arctic does present a unique operating environment in the sense of historical cooperation among nations. However, if conditions change, the DOD must be ready to protect U.S. national interests through continued and increased cooperation, force, equipment, and infrastructure readiness, and by changing the Unified Command Plan to better address the realities of the Arctic domain.

Cooperation among allied Arctic nations can be increased through additional military exercises and military-to-military cooperation to increase preparedness, interoperability, and demonstrate resolve in the face of competitors and adversaries. An increase in cooperation also serves the secondary effect of improving the military's ability to operate under Arctic conditions. The DOD must be ready to provide trained forces, equipment, and infrastructure capable of Arctic operations. The military is making headway with the recent reestablishment of the U.S. Navy's 2d Fleet and rotational U.S. Marine forces in Norway, but currently the overall force is still not prepared to operate and sustain itself without significant coalition assistance. At the same time, the United States faces both an increased Russian military presence, including the most submarine activity in the Atlantic during the last 25 years, and increased Chinese expansion and influence. ${ }^{31}$

Finally, the Unified Command Plan still designates that NORTHCOM and EUCOM share responsibility for the Arctic, a fact that ignores the most likely location of future security conflicts in the Arctic. EUCOM and its Service components are already best postured to conduct coordination with NATO and deter threats. To prevent operational gaps in the Arctic, the DOD should adjust the boundary and designate EUCOM as the overall lead combatant command for the Arctic.

\section{Notes}

1. Christian Le Mière and Jeffrey Mazo, Arctic Opening: Insecurity and Opportunity (New York: Routledge, 2013), 82-83.

2. The terms Arctic nations or states used throughout the document specifically refer to what is known as the "Arctic Eight." These are the eight nations that comprise the core members of the Arctic Council and possess sovereignty above the Arctic Circle. These nations include the United States, Canada, Russia, Iceland, Norway, Finland, Sweden, and Denmark (due to the island of Greenland). Other nations, such as China, possess observer status in the Arctic Circle and profess status as a "Near-Arctic" nation.

3. Mike Stone, "The U.S. Army Estimates Russian Capability Will Peak in 2028, China’s in 2030," Reuters, 26 February 2019. 
4. "Agreements," Arctic Council, last modified 6 December 2018; and Kathrin Stephen, "Areas of (No) Conflict in the Arctic," Arctic Institute, 1 May 2018.

5. "Cooperation in the Arctic Spirit'-Report from the Roundtable on Arctic Security in Stavanger," Munich Security Conference, 28 August 2018.

6. Timothy L. Thomas, Russia's Military Strategy: Impacting 21st Century Reform and Geopolitics (Fort Leavenworth, KS: Foreign Military Studies Office, 2015), 322.

7. Thomas, Russia's Military Strategy, 322-44; and Michael Kofman and Jeffrey Edmonds, "Why the Russian Navy Is a More Capable Adversary Than It Appears," National Interest, 22 August 2017.

8. Fredrik Wesslau and Andrew Wilson, "Russia 2030: A Story of Great Power Dreams and Small Victorious Wars," European Council on Foreign Relations, 23 May 2016, 7.

9. Wesslau and Wilson, "Russia 2030," 2-3.

10. Stone, "The U.S. Army Estimates Russian Capability Will Peak in 2028, China's in 2030."

11. Kyle Rempfer, "Northern Border Along Arctic, Not Southern, Is What Worries NORAD Leaders," Military Times, 28 February 2019.

12. James Stavridis, "China Is Joining the Rush for Arctic Riches: Why Is a Nation with No Polar Shoreline Building Nuclear Icebreakers? Hydrocarbons and Trade Routes," Bloomberg, 16 April 2019.

13. Simon Johnson, "Pompeo: Russia Is 'Aggressive' in Arctic, China's Work There Also Needs Watching," Reuters, 6 May 2019.

14. Report to Congress on Resourcing the Arctic Strategy (Washington, DC: Department of Defense, 2016), 3; and National Strategy for the Arctic Region (Washington, DC: White House, 2013), 2.

15. "Unified Command Plan," Department of Defense, 28 October 2011.

16. "NATO Press Fact Sheets and Backgrounders," NATO, last modified 20 November 2017.

17. Thad W. Allen et al., Arctic Imperatives: Reinforcing U.S. Strategy on America's Fourth Coast, Independent Task Force Report No. 75 (New York: Council on Foreign Relations, 2017), 20.

18. John S. McCain National Defense Authorization Act for Fiscal Year 2019, S. 1247, H. R. 5515, 115th Cong. (2018).

19. "Alaskan Command," Joint Base Elmendorf-Richardson, accessed 21 November 2018; and Ryan Browne, "US to Double Number of Marines in Norway amid Russia Tensions," CNN, 12 June 2018.

20. "Alaskan Command"; and Dr. Richard D. Newton, former Arctic Planner, J5/US Special Operations Command-North, email message to author elaborating the construct of U.S. Air Force Reserve forces in Alaska, 25 February 2019.

21. The United States Navy Arctic Roadmap for 2014 to 2030 (Washington, DC: Department of the Navy, 2014), 18.

22. Arctic Imperatives, 21-43; Report to Congress on Resourcing the Arctic Strategy, 4; and Changes in the Arctic: Background and Issues for Congress (Washington, DC: Congressional Research Service, 2019), 97.

23. Nicole Bauke, "Restoration of U.S. Air Base in Iceland Does Not Mean Troops Will Follow, Navy Says," Navy Times, 10 January 2018.

24. Andrew Feickert, The Unified Command Plan and Combatant Commands: Background and Issues for Congress (Washington, DC: Congressional Research Service, 2013), 65; and Arctic Imperatives, 20.

25. Former senior military planner, future operations (J35), EUCOM, conversation with author regarding combined operations between EUCOM, Service components, and allied/partnered nations, 28 February 2019.

26. Ariel Cohen et al., EUCOM Should Lead U.S. Combatant Commands in Defense of National Interests in the Arctic (Washington, DC: Heritage Foundation, 2011), 8.

27. Cohen et al., EUCOM Should Lead U.S. Combatant Commands in Defense of National Interests in the Arctic, 9. 
28. Finland and Sweden are members of the Euro-Atlantic Partnership Council, the Partnership for Peace, and maintain a national delegation to NATO. They are also part of the Enhanced Opportunities Partnership in NATO, which allows for increased cooperation and intelligence sharing. Russia is also a member of the Partnership for Peace and the NATO-Russia Council; however, meetings are only at the ambassadorial level and have taken place less frequently since 2014.

29. European Deterrence Initiative (Washington, DC: Department of Defense, 2018), 1.

30. Muyin Wang and James E. Overland, "A Sea Ice Free Summer Arctic Within 30 Years: An Update from CMIP5 Models," Geophysical Research Letters 39, no. 18 (September 2012): 1, https://doi.org/10.1029/2012GL052868.

31. Wesley Morgan, "Navy Re-Establishes Atlantic Fleet to Check Russia," Politico, 24 August 2018. 


\title{
The Weaponization of Information Social Media, Commercial Search, and the Changing Character of War
}

\author{
Captain Daniel J. Vigeant, U.S. Army
}

Algorithms of Oppression: How Search Engines Reinforce Racism. By Safiya Umoja Noble. New York: New York University Press, 2019. Pp. 256. \$89 (hardcover); \$28 (paperback).

Like War: The Weaponization of Social Media. By P. W. Singer and Emerson T. Brooking. New York: Eamon Dolan Books, 2018. Pp. 416. \$28.00 (hardcover); \$15.99 (paperback).

In the span of only a few short decades, the internet has become "the most consequential communications development since the advent of the written word" (Singer and Brooking, p. 52). For the first time in written history, anyone with an agenda can promote their message to the global masses with near-instantaneous results. However, the goal of such messaging is not always positive and oftentimes has rippling, real-world effects. In short, information has become a globally recognized currency with intense value; through it, users have the ability to build international communities, influence targeted audiences, and spread misconception on a global scale. This current construct is fostering an environment of misuse, deception, and manipulation that has ultimately weaponized information and altered the character of war.

Two recently published books, P. W. Singer and Emerson T. Brooking's Like War and Safiya Umoja Noble's Algorithms of Oppression, argue, either directly or indirectly, that the globalization of the internet has forever changed the character of war. The internet, as a global depository for accessing information and simultaneous gateway for sharing that information, has the power to sway global opinion, change the outcome of a particular conflict, and even shift political alignments. In Like War, Singer and Brooking argue that the methods by 
which information is being "accessed, manipulated, and spread [has] taken on a new power" and changed the dynamics of conflict (Singer and Brooking, p. 11). Conversely, in Algorithms of Oppression, Noble tackles the bias of information accessibility via commercialized search engines. She argues that complex algorithms prioritize the accessibility of user search results for commercial gain (Noble, p. 25). Both books reach very similar conclusions through the dissection of two relatively dissimilar internet mediums: information access has become commercialized, globally accessible, and dangerously weaponized.

LikeWar is a stunningly well-written analysis of the methods by which social media has weaponized information. The analysis is woven into five core principles that continuously intersect throughout the book. These core principles provide a foundation for understanding social media misuse and manipulation. First, the internet has matured and stabilized. As of 2018, it has become "the preeminent communications medium in the world [and] will remain so for the foreseeable future" (Singer and Brooking, p. 261). Because the internet has become the world's primary communications medium, it has also become a battlefield. Information wars are waged daily, targeting not just individuals but entire populations, and are quickly becoming an "integral part of global conflict" (Singer and Brooking, p. 184). This battlefield is changing how conflicts are fought. Simply stated, the internet has become "a platform for achieving the goals of whichever actor manipulates it most effectively" (Singer and Brooking, p. 261). As a result, the character of war has changed. Internet actors have the ability to accomplish incredible good, but they can equally "foment violence, stoke hate, sow falsehoods, incite wars, and . . . erode the pillars of democracy itself" (Singer and Brooking, p. 23). Finally, everyone is now a participant in this new kind of war. Anyone can be a purveyor of this innovative weapon, but more importantly, anyone can be a target.

Social media has ushered in a new era of low-intensity conflict propagation and resolution. An amalgamation of history, current events, and future predictions reinforce the author's argument that the invention of social media created-largely by accident - an entirely new means of tactical and strategic warfare. Stated another way, it has altered the methods by which wars are waged and won:

Attacking an adversary's most important center of gravity- the spirit of its people-no longer requires massive bombing runs or reams of propaganda. All it takes is a smartphone and a few idle seconds. And anyone can do it. (Singer and Brooking, p. 18)

The pages of LikeWar, just as in the pages of modern history, are littered with examples of social media's weaponization. Semisophisticated Russian interference of the 2016 U.S. presidential election, the Islamic State's effective use 
of hashtags to shape an objective prior to seizure, and China's strategic censorship of state-sponsored social media are just several of the numerous examples the authors cite to support their argument. Viewing these effects as an extension of warfare reinforces one simple truth: members of the profession of arms, both as warfighters and citizen users of social media, must have a baseline knowledge of the influential power of social media within the context of information operations.

Commercial search engines are the primary means by which users access information in the twenty-first century. In Algorithms of Oppression, Noble claims that these search engines are inherently biased and predominantly controlled by paid advertising and commercial interests. Google's search engine, the primary target of her book, "is in fact an advertising platform, not intended to solely serve as a public information resource in the way that . . . a library might" (Noble, p. 38). However, users of search engines predominantly accept the information accessed as reliable and free of error. This presumption must be acknowledged:

We must trouble the notion of [search engines] as a public resource, particularly as institutions become more reliant on [them] when looking for high-quality, contextualized, and credible information. This shift from public institutions such as libraries and schools as brokers of information to the private sector . . . is placing previously public assets in the hands of a multinational corporation for private exploitation. Information is a new commodity, and search engines can function as private information enclosures. (Noble, p. 50)

Substantiating the often-ignored notion that commercial search engines control information access and are owned by private corporations is a notion that cannot be ignored. These companies have replaced public institutions as the chief curators of information with very little legal or intellectual oversight. They have been permitted to write the rules on information access to cater to their primary clients_-the advertisers_-for monetary gain (Noble, p. 162).

Algorithms of Oppression is an in-depth and analytical study of the discriminatory decision-making algorithms inherent in commercial search engines. The author's chief argument is that biases, coded into the artificial intelligence of search algorithms, discriminate against people, especially women of color (Noble, p. 13). Search engines such as Google and Yahoo! are often regarded as a public service. However, the programmers who code these programs are employed by public companies and disconnected from the people and communities that they service. To correct this deficiency, Algorithms of Oppression pleas for "experts in the social sciences and digital humanities to engage in dialogue with . . . engineers, designers, information technologists, and public- 
policy makers before blunt artificial-intelligence decision making trumps nuanced human decision making" (Noble, p. 13). The processes that drive search engine algorithms and control information access are created by programmers but are nonetheless monetarily driven. The author cedes that changes to programming continuously occur, but must continually be monitored, revised, and updated to keep pace with the ever-changing information environment.

Nearly one-half of the world's population is online (Singer and Brooking, p. 51). Unfortunately, the vast majority of this population remains blissfully unaware of the ways and means by which social media and commercial search engines influence decisions and alter behaviors. Both books find success in their primary goal: educating the population on the perils and pitfalls present within these two internet mediums. LikeWar succeeds in reaching a wide audience through relatable anecdotes and an easy-to-read narrative. Algorithms of $O_{p}$ pression targets a more specific audience with a baseline understanding of how internet algorithms and computer coding work. Both books fill a much-needed void in knowledge on the topic of information operations in the twenty-first century. Education on this topic increases awareness and allows for informed decision making concerning the use of social media and commercial search engines.

Both books admittedly suffer from the exponential speed at which the internet is evolving. Literature focusing on internet studies is outdated before it has a chance to be published because of the rapid pace of change. In Algorithms of Oppression, the author admits, "by the time readers engage with [the book], it will be a historical rather than contemporary study" (Noble, p. 16). Many of the arguments, valid between 2009 and 2015 when the book was researched, are now obsolete or nonexistent. The same is true for LikeWar. The internet is constantly evolving and its users are adapting with the ebbs and flows of its change. Ultimately, both books are a snapshot of the internet and social media at a given point in history; understanding them as such provides a frame of reference for their intake and fosters future study of these two mediums. 


\title{
A Riddle Unwrapped North Korea and the World
}

\author{
Leo J. Daugherty III, PhD
}

\begin{abstract}
North Korean Military Proliferation in the Middle East and Africa: Enabling Violence and Instability. By Bruce E. Bechtol Jr. Lexington: University Press of Kentucky, 2018. Pp. 274. $\$ 80.00$ (hardcover).
\end{abstract}

North Korea and the World: Human Rights, Arms Control, and Strategies for Negotiations. By Walter C. Clemens Jr. Lexington: University Press of Kentucky, 2016. Pp. 464. \$39.95 (hardcover).

The recent summit meeting between President Donald J. Trump and North Korean leader Kim Jong-un in Hanoi, Vietnam, has once again placed the spotlight not only on North Korea but on its off again/on again relationships with the outside world, most importantly the United States. This relationship has been one of both open hostility and deep suspicion, leaving one to describe Pyongyang's worldview, to paraphrase the late British prime minister Winston Churchill's description of the Soviet Union as "a riddle, wrapped in a mystery, inside an enigma." Bruce E. Bechtol's North Korean Military Proliferation in the Middle East and Africa: Violence and Instability and Walter C. Clemens's North Korea and the World: Human Rights, Arms Control, and Strategies for Negotiations shed important light on a country, a people, and a regime that since 1945 have been at the epicenter of tension in northern Asia and the world and dominated the agendas of U.S. administrations for more than seven decades. Both Bechtol and Clemens provide a scholarly though highly readable account of how North Korea has benefited politically, militarily, and profited monetarily from its position as perhaps one of the last of the neo-Stalinist regimes left from the Cold War. 
Bechtol's North Korean Military Proliferation in the Middle East and Africa is a careful, concise look at how Pyongyang, since the end of the Cold War in the early 1990s has, over the years, developed a vast arms market that stretches from the Bashar al-Assad regime in Syria to the ayatollahs in Iran as well as its proliferation and sale of weapons of mass destruction (WMD) to rogue regimes such as Cuba and nonstate actors that include various terrorist groups in the Middle East (Hezbollah and Hamas) and rogue regimes in Africa. Acting as a proxy for the former Soviet Union until the latter's demise in 1991, Pyongyang now serves as the main supplier of illegal arms to regimes and groups hostile to the West. Furthermore, as Bechtol wrote, North Korean agents, acting in unison with policy objectives set forth by Kim Jong-un (as well as his grandfather and father, respectively), have carved out a lucrative though very dangerous arms trade that has been able to avoid international sanctions from the West as well as pressure from the People's Republic of China, North Korea's northern neighbor. This vast proliferation of arms by Pyongyang has not only proven financially lucrative but it has elevated its status as a major source of illicit arms for rogue regimes. More important is the fact that "the [arms] proliferation that North Korea engages in presents a number of foreign policy challenges to the United States." Through careful research and analysis, Bechtol outlines how Pyongyang emerged as a major arms supplier in areas of geostrategic importance to the United States, which is a critical theme of this well-researched book.

Indeed, prior to the end of the Cold War, North Korea's activities received very little attention as the focus on its sponsor, the Soviet Union, diverted attention away from Pyongyang. When the Soviet regime collapsed in 1991, North Korea, by that time, had established a network of client states that enabled it to replace the Soviet Union as the main suppliers of both conventional arms (e.g., tanks, small arms, and explosives), as well as a limited though growing arsenal of WMDs to include nuclear and biological weapons, which it sold to several rogue regimes worldwide, most noticeably Syria and Iran. Bechtol wrote that despite the "crippling" international sanctions levied on Pyongyang by several American presidential administrations, North Korea has somehow managed, through deceit and a change in tactics and techniques, to hamper the West's efforts to stop or at the minimum to slow the proliferation of arms by this rogue nation.

Bechtol's book is broken down into seven well-organized and wellresearched chapters that discuss Pyongyang's efforts in the Middle East with the Assad regime and the ayatollahs in Tehran. The author rightfully asserts that both regimes have come to depend on Pyongyang's willingness to sell WMDs as well as conventional arms despite the ongoing efforts by the United States and its allies to halt such arms transfers. As a result of the West's inability to stop such arms transfers, North Korea has only become emboldened in its efforts to 
sell arms to circumvent the sanctions that have left the country bankrupt and unable to feed itself.

Walter E. Clemens's North Korea and the World is a detailed analysis of North Korea since its founding in 1946. As the author of this fine book asserts, North Korea and its leadership, beginning with Kim Il-sung, were "born in a mystery," more oligarchic than Communist in nature, and one that conformed to centralization rather than democracy or pluralism in the Western sense. Starting with an examination of the origins of the North Korean state and of its ruling dynasty, the author successfully illustrated that the modern North Korea is a product of its past history-one formed by political struggles and the neglect by its ruling elite of its economic development. In short, North Korea has failed where its cousin to the south has succeeded-in accepting modernity and economic diversification. While South Korea prospered and slowly democratized after 1953, North Korea became increasingly isolationist and dependent on the two Communist giants that today have either thrown off Communism (the Soviet Union) or has become more capitalistic (the People's Republic of China or PRC), but remains today as one of two regimes (Cuba being the other) embracing a neo-Stalinist, totalitarian form of government.

The strength of Clemens's book lies in his ability to tell the whole story of why North Korea acts the way it does at home and abroad, beginning with the rise of Kim Il-sung and the post-World War II struggle between the Soviet Union and the United States. As Clemens maintained, North Korea's identity has been shaped by its history and culture, two important factors that have allowed it to survive and grow during the 1950s and 1960s. Pyongyang's emergence as a modern nation-state came at a time when the Soviet Union and the People's Republic of China (to a limited degree) found a very willing partner in Pyongyang to carry out its bidding on the Korean Peninsula, throughout Asia, and the world. Both Bechtol and Clemens agree that when the Soviet Union collapsed and the PRC became more interested in pursuing capitalism, Pyongyang set out on a course of nuclear proliferation and economic development meant to establish its own identity. The establishment of its own identity as a source of arms for rogue regimes, however, has served only to further tensions on the world scene, most noticeably with that of the United States and Japan in northern Asia and the Middle East.

One of the strongest points of Clemens's book revolves around his discussion of Washington's attempts to negotiate with Pyongyang-attempts that have either ended in stalemate or disappointment-as President Trump has most recently discovered in his latest attempt to negotiate an end to North Korea's missile testing and its proliferation of WMDs. These disappointments have occurred, Clemens argues, due largely in part to the naivety and inability of the American leadership to understand North Korea's history and culture that have 
shaped its view of the outside world. In short, as Clemens argues, Washington has approached its relations with Pyongyang through the prism of the Cold War and not from a historical perspective that takes into consideration North Korea's long history and culture.

While both books are well-written and well-researched, there is one major omission in both books that is quite obvious. Both books discuss Pyongyang's relationship with the PRC, Japan, and the United States; the major omission is that of any serious discussion of its relations with the Soviet Union and its successor state, the Russian Federation. In fact, this is a serious omission. Since 1945, the Soviet Union from Joseph Stalin through Vladimir Putin's Russian Federation — and not the PRC_-has held the key in our dealings with the regime in Pyongyang as has been highlighted with Kim Jong-un's April 2019 summit with Russian leader Vladimir Putin. While both Bechtol and Clemens discuss Russia as a source of arms and financial support, both authors would have been better served to include a separate chapter on how the Soviet Union and Russia have influenced Pyongyang since the end of World War II through today.

Despite this shortcoming, however, both Bechtol's North Korean Military Proliferation and Clemens's North Korea: A World View are two books that are timely, important, and relevant. While Bechtol's book is pricey, both books fill an important gap in the literature on North Korea, and as such should be read to gain a better understanding of the motivation of North Koreas leadership and its relationship with the international community. These two books highlight the difficulties the West faces in its dealing with Pyongyang, a regime that to this day remains "a riddle, wrapped in a mystery, inside an enigma." 
Exceptional America: What Divides Americans from the World and from Each Other. By Mugambi Jouet. Berkeley: University of California Press, 2017. Pp. 376. \$29.95 (hardcover); \$29.95 (e-book).

Mugambi Jouet is an accomplished lawyer and Stanford University law professor who, in Exceptional America, dives into cultural critique. His analysis of the American culture wars derives from his prior experiences in the legal realm, his cosmopolitan background, and his exceptional educational career. On the last, this first book from Jouet uses skills learned during his bachelor's degree in history, master's in public policy, and Juris Doctorate. Few authors bring this kind of interdisciplinary approach to culture wars topics.

In Exceptional America, Jouet argues that "American exceptionalism is not only what divides Americans from the world [but] it also ... divides Americans from each other" (pp. 6-7). The nation's "acute social conflicts and injustices" are "part of a historical cycle" with "old roots even as they take on new forms" (p. 6). Jouet warns that these conflicts have resulted in a polarization that might foretell America's decline (p. 5). Indeed, on the world stage, he argues that "conservative America has become an outlier in the Western world because of its growing radicalization over the past three decades" (p. ix). In an increasingly globalized world, the United States has become exceptional for its insularity and myopia (pp. 12, 169, 238-39, 268). American exceptionalism is, in Jouet's view, entirely negative both at home and abroad.

Key mind-sets or "interrelated ideologies" for Jouet include "profound anti-intellectualism, fervent Christian fundamentalism, a visceral suspicion of government, and racial resentment" (pp. ix, 78). These are covered in eight chapters that address history (deep and/or recent) and present developments. The coverage of major historical and recent political figures and commentators is excellent. They include Alexis de Tocqueville, Richard Hofstadter, and nearly every president from Franklin D. Roosevelt to Donald J. Trump, along with many politicians and political commentators from the last three decades. Indeed, Exceptional America's history, or historical analysis, deals primarily with the last 30 years. 
In identifying the "old roots" of cyclical conflicts and injustices, Jouet's analysis mirrors past historians and critics who have written on anti-intellectualism and America's culture wars. On the former, the author follows the lead of Richard Hofstadter. In his seminal 1963 book on the topic, Anti-Intellectualism in American Life, the entire first historical section focuses on the Protestant and evangelical roots of anti-intellectual tendencies in American culture, from John Winthrop to Dwight L. Moody and Billy Sunday and early twentieth-century fundamentalism. Others, such as Susan Jacoby in Age of American Unreason: Dumbing Down and the Future of Democracy (2008), have followed suit. Jouet modifies his thesis in relation to Christian fundamentalism by the end of chapter three, where he states that it has influenced "other aspects of modern America, from attitudes toward economics to social policy, criminal justice, and foreign affairs" (p. 112). He particularly laments religion's influence on the Republican Party since the 1980s (pp. 112, 262). That Jouet sees religion as the major culprit is clear when he adds that Christian "fundamentalism may lead to American decline" because it "fosters a purist, uncompromising, far-right ideology that impedes rational decision-making and problem-solving" (p. 112). Christian fundamentalism is the causal agent in Jouet's narrative, and its pernicious fostering of irrationalism and anti-intellectualism are the main elements of its influence on American insularity (p. 109).

One of the strengths of this book is its insider/outsider perspective. This aspect of the work is both personal for Jouet and formally part of his analysis. Jouet's family roots are in Kenya and France, but he was educated in the latter and clearly identifies more with his French heritage-hence that country's dominance in the comparative aspects of the book (pp. 14-15). When Jouet makes international comparisons beyond France, his primary objects are generally northern and western European nations-Sweden, Denmark, Germany, Spain, and Ireland - with a few references to Italy, Norway, Poland, and Portugal. Great Britain is curiously absent. China and Japan are present, as is Australia. Even when subjective and qualitative, this comparative analysis makes Jouet's work a valuable contribution to the literature on American culture wars and exceptionalism.

This book is particularly strong in its second half, where Jouet covers economic inequality, race, mass incarceration, and gun violence. The thesis of chapter 6, echoing Thomas Frank's famous 2004 work What's the Matter with Kansas?: How Conservatives Won the Heart of America, is that "millions of common people stand against their own economic interest by defending policies that heavily benefit the richest of the rich" (pp. 168, 169, 173). Jouet, however, argues against hot-button culture wars issues, such as abortion, as decisive, favoring instead the decisiveness of an overlapping ideology of market and re- 
ligious fundamentalism (p. 175). In favoring market fundamentalism, Joet's analysis mirrors, somewhat, Daniel T. Rodgers's Age of Fracture (2011).

Feeding this confluence, Jouet argues, is unbridled individualism. That manifests in the American dream of obtaining affluence, he continues, making it easier to downplay systemic injustices (pp. 179-80). Conservatives and Republicans, Jouet says, make the American dream a "factual proposition" and possibility, even when structured economic inequality makes it implausible (p. 183). The Republicans maintain that the government is an obstacle to your success and have worked to dismantle it—even while blaming victims of systemic inequality for their own failures (pp. 182-83). The victim blaming has enabled dog-whistle politics, used by Republicans, that claims people of color do not want to work. If the country has economic problems, they say, it is because too many want handouts from the welfare state (pp. 186-89).

All of this obfuscates systemic injustices, in education and the workplace, and enables political claims about the unwillingness to work to result in crime, either through the sedation of drug use or outright theft. Jouet brings this together in chapter 7, on mass incarceration and gun violence. The "U.S. criminal justice system," he argues, has become, since the 1960s, "a microcosm of American exceptionalism" (p. 194). The key theme is its emphasis on "offenders as little more than evildoers," resulting in "harsh retribution, not rehabilitation or prevention" (p. 195). To religious fundamentalists, this is "divine retribution" (pp. 214-17). This has become a shared, cross-party ethic, and it makes us an international outlier in terms of executions and draconian prison terms (p. 195). Jouet astutely observes that criminal justice systems often reflect economic systems and a "society's overarching values" (pp. 207, 213). By punishing the poor, our system overwhelming incarcerates people of color and minorities. But this is based on a faulty calculation of the costs of the death penalty (highly expensive) versus life without parole, which is "far less expensive" (pp. 215, 222-23). In general, Jouet notes, "killing seems more socially acceptable" in the United States than in most of the Western world, and this converges with executions, gun violence, and gun toting. It is indicative of "a broader subculture of violence" (p. 220). The language of righteousness and force also characterize America's dealings with the world, as outlined in chapter 8 on international relations and the War on Terrorism.

While the second half of the Exceptional America displays Jouet's strengths, there are systemic issues that weaken his overall argument. Tone is something of a problem in the book. If you have read this far into the review, it will come as no surprise that Jouet harbors what some might call a liberal worldview or anticonservative bias. While the narrative is informed with facts and contains no major errors, the book sometimes reads as a checklist of liberal stereotypi- 
cal views of recent and current events. President Barack H. Obama is a hero, and conservative politicians, as well as Presidents George W. Bush and Donald Trump, are the villains. While Jouet's French background gives the book an outsider perspective, or at least the veneer of one, it comes with a bit of stereotypical French, secular contempt for the lowbrow, apparently retrograde aspects of American life, especially religion. Apart from that, the overall tone means this book will not challenge those who see themselves as liberals.

Even though Jouet does not pretend to be a historian, his use of history in building the book's argument opens him to concerns about its misuse. This reviewer's chief concern is the error, or fallacy, of presentism in that the book feels like a diagnosis based on the circumstances of the patient's immediate presentation: the patient is America, and the primary symptom is Trump's election. Jouet is aware that he might be charged with this fallacy because the third sentence of his preface declares that he had been writing this book for "several years before" the November 2016 election (p. ix). If that is true, Jouet was not shy about retrofitting his thesis with citations and references related to Trump. Roughly one-quarter of the book refers to the current president, and the index entry for him is one of the most extensive in the book. In Jouet's teleological telling, the only question might be why it has taken so long to elect a political character like Trump.

Given that anti-intellectualism is a central, foundational theme in Exceptional America, and given that "ignorance" receives explicit attention in the text and index, it is surprising that Jouet does not avail himself of the scholarly literature on the topic. Known as agnotology in academic circles, the study of ignorance received increased attention in 2008 with the publication of Robert N. Proctor and Londa Schiebinger's edited collection, Agnotology: The Making and Unmaking of Ignorance (2008). That work has been followed by others using the agnotological principles, including Naomi Oreskes and Erik M. Conway's Merchants of Doubt: How a Handful of Scientists Obscured the Truth on Issues from Tobacco Smoke to Global Warming (2010) and a collection edited by A. J. Angulo, titled Miseducation: A History of Ignorance-Making in America and Abroad (2016). All of these works outline how ignorance is accidentally and purposely structured into certain areas of thought, including science, schools, colleges, history, medicine, and politics. These studies do not absolve American citizens from thinking and taking responsibility for their votes and inaction. But they do help explain how certain areas of anti-intellectualism persist in a society that values the free, uncontrolled exchange of information and knowledge.

Despite these criticisms, Jouet's Exceptional America adds value to the existing literature on the culture wars in America. His comparative perspective, even if slanted toward certain Western countries, helps interject baseline norms and values into an American context that has shifted right over the years. That drift 
explains, in part, how the United States has become divisive on the world stage. Of course, some American nationalists will argue that any comparative endeavor is "liberal" at base, given the exceptional nature of America's founding and apparent global mission. But Jouet's ambitious first book was created, explicitly, to counter that perspective and is therefore a needed perspective.

Tim Lacy, PhD

Educator, instructor, independent historian, and author of The Dream of a Democratic Culture: Mortimer J. Adler and the Great Books Idea (2013).

Ioutou: Kokusaku ni Honrō Sareta 130 Nen (Iwo Jima: 130 Years at the Mercy of National Policy). By Ishihara Shun. Tokyo: Chūkō Shinsho, 2019. Pp. 221. $¥ 886$ (paperback).

The island of Iwo To, more commonly known as Iwo Jima until 2007, was one of the harshest battlegrounds of World War II. As such, it remains transfixed in the memories of both Americans and Japanese alike for the sacrifices made during the monthlong fight there in early 1945. It is also the subject of numerous military history books and memoirs. One recent book is the translated memoirs of Horie Yoshitaka, who served on Lieutenant General Kuribayashi Tadao's staff, coedited by this reviewer and Iwo veteran Charles Tatum, entitled Fighting Spirit (2011). Another is Iwo Jima and the Bonin Islands in U.S.-Japan Relations: American Strategy, Japanese Territory, and the Islanders In-Between (2014), which is the English version of this reviewer's 2008 book published in Japanese. The story of Iwo Jima as political and diplomatic history, however, is less known. The aforementioned Iwo Jima and the Bonin Islands was probably the first book to bring its full history — prewar, wartime, and postwar — to light. Nevertheless, a much more detailed look at the 50-year period following reversion of the islands on 26 June 1968 was necessary.

Ioutou was written by Ishihara Shun, a professor at Meiji Gakuin University in Tokyo who specializes in sociology and history with a focus on island studies, to provide a more comprehensive study of Iwo Jima as a whole. He wanted to show that the island was more than just a battle, especially for its original residents, who remain unable to return to live there since being evacuated to mainland Japan in 1944 prior to the Battle of Iwo Jima (p. vi). Their inability to return to their home was not only true during the years of U.S. occupation and administration between 1945 and 1968 but also during the post-reversion period, which is one of the main subjects of chapter 6 , the book's secondlongest chapter. 
Another reason Ishihara wrote this easily readable book was to place Iwo Jima in a larger international history of Japan's colonial expansion in the Pacific islands (p. vi). It was in this latter context that this reviewer first met Ishihara at the second of a series of multidisciplinary conferences on Chichi Jima, one of Iwo Jima's two inhabited neighboring islands. Scholars and students came from many countries in the region and possessed different academic backgrounds and interests. The result was the first-ever edited book on Ogasawaragaku Koto Hajime (An Introduction to Ogasawara Studies) (2002). Ishihara attended the second biennial conference in the summer of 2002.

At that time, Ishihara was a graduate student with an intense interest and focus, and his passion for the subject remains as strong today as it was then. During the past decade-plus, he has published several Japanese-language books and articles related to Ogasawara and Iwo Jima. Ioutou draws from these previous works, including several articles rewritten for this book (pp. 209-10).

The book is 221 pages in length and organized into six chronological chapters, not including an introduction, a conclusion, and an afterword. While the volume lacks an index, as many Japanese-language books do, Ioutou does include a helpful eight-page bibliography. Because the book is written from a Japanese perspective for Japanese readers, all but four entries are Japanese-language sources. The book also includes 25 photos, including some taken by Ishihara during a visit to Iwo Jima or of interviews he conducted as well as 6 charts and 2 maps.

Chapter 1, which covers the period from the sixteenth century through the 1920s, looks at the discovery of the island group, its inclusion as Japanese territory, and its settlement by Japanese citizens. Chapter 2 details life on Iwo Jima as a plantation, focusing on the early 1930s to 1944 . This chapter will help those with an interest in the Battle of Iwo Jima who wish to fill in some of the history of the island before the battle that tends to dominate most books on the subject.

Chapter 3 examines the forced removal of islanders in 1944 and the mobilization of some of them for military detail. This chapter, too, will be of interest to those seeking to learn about the preparations for the battle from the Japanese perspective and how noncombatants were relocated to other areas. Chapter 4 looks at the Battle of Iwo Jima from the Japanese side and the islanders involved, including the testimony of one resident, Sudō Akira. Chapter 5 covers the U.S. occupation period and the islanders' permanent loss of their home.

Finally, chapter 6 discusses the post-reversion period and the introduction of Japan Self-Defense Forces to the island, the modifications of existing military facilities on the island, accommodation of field carrier landing practice by the U.S. Navy and other jets, training exercises on the island, and the ongoing search for remains of those lost in the battle. 
Currently, this book is only available in Japanese. Nearly 300 new titles are published every day in Japan, but almost all of them never reach foreign markets due to not being available in English or other languages. This lack of access is a problem for non-Japanese language readers, but it also a problem for Japan in that it is unable to share the products of its research literature, or other writings abroad.

In any case, Dr. Ishihara's book provides an important Japanese perspective on a topic that remains of great interest to Americans, particularly with the 75th anniversary of the end of World War II around the corner.

Robert D. Eldridge, PhD

President, The Eldridge Think Tank

American Power \& Liberal Order: A Conservative Internationalist Grand Strategy. By Paul D. Miller. Washington, DC: Georgetown University Press, 2018. Pp. 323. \$64.95 (hardcover); \$32.95 (paperback and ebook).

Ahead of the 2016 U.S. presidential elections, a Pew Research Center poll found that 57 percent of Americans agreed with the statement: the United States should "deal with its own problems and let others deal with theirs the best they can." Compounded by America's post-9/11 protracted wars and congressional bipartisanship on America's role in the world coming under strain, the intent for lesser American activism abroad has borne existential questions for U.S. grand strategy.

In his book American Power \& Liberal Order: A Conservative Internationalist Grand Strategy, Paul D. Miller offers conservative internationalism as an American grand strategy best suited for addressing the dichotomy presented by an increasingly inward-looking, conflict-fatigued U.S. electorate and a world imperiled by nuclear autocracies being "more confident than ever"; armed nonstate actors having "access to ever-greater resources"; and the transnational jihadist movement having "yet to be dealt a definitive blow" (p. xiv).

Miller makes an emphatic case for sustaining the liberal order because it is "mutually constitutive" with American security. Given the declining popularity of liberal internationalism, only accentuated by an "America First" worldview, conservative internationalism as a grand strategy is argued to be superior to restraint as being "more farsighted and morally defensible." It is also deemed superior to liberal internationalism given its emphasis on being "realistic and achievable" (p. 279). In many ways, it attempts to "blend the strengths of realism and liberal internationalism" (p. 26). 
In their seminal work U.S. Defense Politics: The Origins of Security Policy (2017), Caitlin Talmadge, Eugene Gholz, and Harvey M. Sapolsky define four grand strategies in U.S. foreign and security policy decision making: primacy, liberal internationalism, selective engagement, and restraint. If these four strategies were to be marked by their degree of activism, they represent a scale of extremes reflecting high to low U.S. stewardship, broad to narrow conception of U.S. interests, and more to less employment of U.S. force.

Given conservative internationalism's emphasis on the liberal order being the "outer perimeter" of U.S. security and constituting a "cost-effective" approach short of retrenchment, it may be marked around selective engagement, albeit its position would be tilting toward liberal internationalism on the scale.

One may construe the same as perceptive selective engagement, given Miller's derision of restraint's "short-sighted" prescription of "narrowly focusing on the territorial security of the United States while neglecting the nature of the world order" (p. 13). Instead, it perceptively views sustaining U.S.-led alliances and institutions of the liberal order as "a form of 'insurance' against the uncertainties of the future" (p. 17).

In further distinguishing conservative internationalism from restraint, much like Barry R. Posen in his book Restraint: A New Foundation for U.S. Grand Strategy (2014), Miller goes beyond mere descriptive assessments. The same is done via distinguishing regions as frontline (Europe and East Asia), opportunity (South Asia), quagmire (the Middle East), and periphery (Latin America and Africa). In doing so, however, conservative internationalism's bent toward liberal internationalism's instincts is most apparent in the case of the "frontlines" of Europe and East Asia.

Miller deems Europe to be the "most important geopolitical theater for the United States." In underscoring the criticality of its stability, Miller points out that Europe, including Russia, hones "about a quarter of global power, more than a third of U.S. trade, and three of the world's nine nuclear weapon states. Europe is the largest concentration of liberal democracies in the world, the headquarters for many of the world's most important international institutions, and collectively constitutes a primary pillar of support for liberal order" (p. 159).

In contrast, Posen argues Europe is the "easiest region" to implement a strategy of restraint since the region's economies "have been rebuilt and democracies have flourished." Restraint thus advocates for the United States to disengage from the region "to accustom Europeans to managing their own security affairs" (Posen, p. 67).

Miller's case for Europe's criticality holds water in light of recent developments such as Russia's annexation of Crimea, the rise of populist strongman leaders like Victor Orban in Hungary, the weakening of regional bulwarks of 
liberal ideals like Germany's Angela Merkel, and continued anxieties over a no-deal Brexit. Hence, conservative internationalism rightly dictates for the United States to largely stay the course with its prescribed role: "Stay in NATO, maintain the alliance, resist Russia's attempts to expand its influence through illegitimate means, and keep the peace" (p. 159).

On East Asia and China, Miller underscores its criticality as the "second most important geopolitical theater for U.S. interests, accounting for a third of U.S. trade and a slightly smaller proportion of world GDP, two nuclear-weapon states (and perhaps two more near-nuclear states), though only a fifth of global power" (p. 164). On China challenging the United States, conservative internationalism underscores the U.S.-China security dynamic to "not mirror the Cold War or fall easily into the conventional categories of analysis, such as hegemony, competition, or cooperation, but evolve into something distinctive" (p. 166). Miller argues for confronting China's use of coercion to rewrite the balance of power in the region. Recognizing that as a "threat to liberal order," Miller clarifies the response to not necessarily be belligerent, but to be firm (p. 167).

Restraint, too, advocates for the abandonment of a "Cold War model" of containing China's rise. However, it rests the argument on the premise of the United States recognizing its inherent secure geopolitical position. Posen argues that China's economic power is highly enmeshed in global trade, making it susceptible to a naval blockade, and highlights its geographic encirclement by two nuclear weapon states, Russia and India, and two near-nuclear weapon states, Japan and South Korea.

However, one may argue that such a realization of America's inherent security may spur complacency on China pushing the envelope on post-Second World War dictums and norms, causing a slow erosion of the rules-based liberal order via setting untoward precedents. Recent developments, such as China's militarization of the South China Sea and use of debt-trap diplomacy to attain strategic vassals add credence to Miller's call for a "firm" response-certainly short of war.

Miller's prescriptions, however, stand reminiscent of the last most-vocal liberal internationalist U.S. administration. The William J. "Bill” Clinton administration is often recounted as a touchstone of America's Asia policy, given the "pertinence" of then deputy secretary of state Robert B. Zoellick's idea to pursue China's integration into the liberal order as a "responsible stakeholder."

Similarly, Miller advocates emphasizing the upsides of China's integration into the liberal order. For example, since joining the World Trade Organization in 2001, China has lifted about 300 million people out of poverty and received increased voting rights at the International Monetary Fund and World Bank. In touting these developments, Miller argues for a balanced approach of not starting a war or "humiliat[ing] the People's Republic but . . . counter[ing] China's 
coercive diplomacy in kind and forcibly socializ[ing] China into responsible great power behavior" (p. 167).

Thus, with regards to Europe and Asia, conservative internationalism seems proactive, much like the activist grand strategies of liberal internationalism. However, the same stands distinguished as being warranted against pressing near-term challenges in Europe and Asia. Moreover, the same is advocated in recognition of America's relative decline as an axiom of the prevailing multipolar world.

In denouncing liberal internationalism's advocacy of American stewardship stemming out of romantic conceptions of American Exceptionalism-à la an "indispensable nation" or a "shining city upon a hill" — conservative internationalism underscores a rising "incentive to invest in liberal order as an extension of American influence" in the face of a declining ability for the United States to "rely on its raw power advantage" (pp. 13-15).

The limited parallels with liberal internationalism aside, Miller's sense of a "conservative" internationalism is most apparent in his approach to the tension between protecting America and advancing liberal ideals (p. 24).

In conceding stability operations or "nation-building," as derided by advocates of restraint, to be highly "unpopular" with the American public, Miller argues for a more "coherent doctrine" in envisioning a conservative internationalist grand strategy (pp. 140-45). Miller decries liberal internationalists' argument of the United States having a "moral obligation to fix every failed state" (p. 133). Instead, he advocates for the essential ones to be framed as "essential preventive exercises of hard power against defined threats" (p. 144).

Furthermore, in tacit recognition of the downsides of an overtly militarized approach, Miller rightly advocates for a more sustained employment of foreign aid and an increase in civilian operations to compliment tactical aims of the military. The author also urges the acceptance of the fact that "different states fail in different ways" (p. 146). To that end, he offers a typology of failed states - anarchic, illegitimate, incompetent, unproductive, and barbaric-as requiring different prescriptions.

In offering these distinctions, Miller not only furthers scholarship on the nontraditional challenges to the Westphalian system but also opens the door to increased nuance on the decision-making level. With regards to this point specifically, it is apparent that his prescriptions are well-grounded in practice, given his extensive experience in deliberative roles at the National Security Council, the Central Intelligence Agency (CIA), and the U.S. Army. Fundamentally, Miller's astute recommendations add credence to the oft-dismissed yet highly relevant view of encouraging more practitioners to compliment theoreticians' scholarship. 
Miller's book also makes it particularly relevant with regards to another contemporary debate. In his work The Hell of Good Intentions: America's Foreign Policy Elite and the Decline of U.S. Primacy (2018), Stephen M. Walt derides the "foreign policy community" for institutionalizing liberal internationalism as a standard preset of the U.S. worldview. Disparaged as "the Blob," this group of professionals are alleged to have seen "liberal hegemony and unceasing global activism" as constituting "a full-employment strategy for the entire foreign policy community" (Walt, p. 112).

Miller, however, advocates for a clear-eyed conception of American interests, amounting to a cost-effective approach while falling short of espousing restraint advocates' "misunderstanding of the relationship between American security and world order" (p. 10). Miller notes recent failures of encouraging liberalism in Iraq and Afghanistan have "given new life to advocates of restraint who believe there is no meaningful connection between American security and liberal order and that efforts to build liberal order are expensive ways of proving its futility" (p. 53).

In surely accepting a certain degree of overreach of liberalism in U.S. activism abroad, Miller defends internationalism from "scholars or policymakers," allowing "previous failures" to delegitimize "future efforts" (p. 60).

Such a case for internationalism does not stem from heady optimism or "great delusion," as John J. Mearsheimer refers to liberal aspirations in The Great Delusion: Liberal Dreams and International Realities (2018), but from an understanding of the liberal order being "an extension of American-and other democracies'-power" (Mearsheimer, p. 15). This nuance by a former U.S. national security official on the mutual dependency of American security and liberal order, while recognizing hegemonic excesses and liberal fallacies, only disproves Walt's reductionist, broad-stroked idea of the prevalence of giddyheaded liberal activism among America's foreign and security policy community.

In summation, American Power and Liberal Order offers a much-needed deliberation over a conservative, yet internationalist, American grand strategy in face of the "bipartisan internationalist consensus" on America's promotion of liberal ideals crumbling in recent times (p. ix). This book is a must-have for all watchers of U.S. foreign policy at this pivotal juncture in time marked by a decline in the currency of liberal internationalism.

\section{Kashish Parpiani}

Research fellow at the Observer Research Foundation's centre in Mumbai, India 
All Measures Short of War: The Contest for the 21st Century and the Future of American Power. By Thomas J. Wright. New Haven, CT: Yale University Press, 2017. Pp. 288. \$27.50 (hardcover); \$20.00 (paperback).

Currently, few world affairs watchers doubt that global politics, and American participation in it, is badly challenged. In All Measures Short of War, Thomas J. Wright tries to make sense of it. Though he does so successfully, his conclusion is less than optimistic. And since his book's publication, things have only gotten worse. American foreign policy faces more and more difficulty on a regular basis. In addition, discord seems to reign at all levels as the Trump administration muddles about inconsistently.

In his first few chapters, Wright tries to explain and diagnose issues. In the last three, he proposes policies to adjust, considering the Trump administration appears to have flipped policy on a variety of issues. For instance, Trump declared commitment to a policy of "America First" during the 2016 election campaign, and he has leaned toward isolationism and personal diplomacy as president, replacing almost seven decades of internationalism and American leadership protocol.

Altogether, All Measures Short of War is concise yet incisive. It should appeal to those who seek to understand the complexity and challenges of current geopolitical affairs. Appropriately, Wright begins his narrative with the premise that after the Soviet Union's collapse, American foreign policy vision turned to the idea of convergence. Accordingly, this basically optimistic view held that the "liberal international order" could now carry on independent of American powers. With ideology essentially out of the picture, worldwide democratization might prevail.

Wright holds that this was wishful thinking. Globalization appealed to many but could not stand on its own because nationalism, religious divergence, and cultural divides stood in the way. U.S. policy makers and Western allies hoped that the new liberal international order would encourage old Cold War rivals, particularly Russia and China, to democratize and liberalize. Actually, Wright observes, America's two old adversaries felt their systems threatened. He asserts that the United States and the European Union sought to once again surround Russia as former client states, now independent nations, sought Western allegiance. In a United Nations speech in 2014, Russian president Vladimir Putin accused the American and European allies of disregarding international law. In effect, he declared a new Cold War. Meanwhile, China, after three decades of double-digit economic expansion thanks to its transformation to a free economy, held to its rigid Communist government system. At the same time, the nation initiated a policy of geographic influence expansion. This activity eventually alarmed U.S. officials, for the United States had heretofore enjoyed 
almost complete unabashed and unhindered influence in the Western Pacific region.

Next, Wright turns to other dominant U.S. geopolitical topics. First among those comes Europe, the keystone of America's post-World War II policy that epitomized U.S. world leadership in the Cold War's liberal international order. Henceforth, America's policy of "convergence" took hold. It persisted, Wright notes, until European unity began to falter in the face of "revisionism," which appeared in the early 2000s. Nations sought to revise the status quo to suit individual national interests regarding the economy, immigration, and more. Chief concerns among U.S. policy makers were Russia; China; and the Muslim world, including North Africa.

Russian revisionism manifested itself most visibly in 2014 when Putin, now firmly in power, asserted traditional Russian "defensive" and national interests by occupying Crimea. He surmised that the U.S./NATO/EU bloc would unlikely do anything aggressive about it —and he was correct. Then came events in Eastern Ukraine, which, it seems, moved Wright to make his thoughts known. Things looked ominous. Next, Trump took the stage in 2016 with talk of "America First," representing a clear threat to the liberal international order. This worried Wright, as it did like-minded policy advocates, prompting him to begin his book.

Wright then proceeds to other U.S. concerns such as nuclear proliferation in Iran and North Korea and the double-edged role of interdependence. It appears that American foreign policy had found itself in almost constant diplomatic crisis. Consequently, Wright, apparently thinking of Trump's "America First" attitude, foresaw serious problems. In response, he proposes his idea of "responsible competition" to deal with current diverse national policies, especially the ongoing turmoil in Russia, China, and the Middle East. This principle calls for recognizing the challenges and dangers of ill-advised responses to events as nations struggle with their own brands of revisionism. History is full of illustrations that prove that liberal internationalism has succeeded, however awkwardly, since the end of World War II. Consequently, Wright holds that Trump's tilt toward isolationism and "America First" is inevitably dangerous.

Supporting Wright's opinion is that isolationism has never worked in the American experience. George Washington's farewell address in 1796 called for a policy of avoiding "entangling alliances" —in other words, advocating for isolationism. Many decades of attempting to implement that sort of policy along with tariffs and immigration restrictions has invariably led to economic, diplomatic, and political discord. To some extent, it may be happening in the United States again right now. Indeed, considering the current state of affairs, it is manifestly important to remember that America's rejection of the League of Nations 
played a large part in the organization's ineffectiveness and the coming of World War II. It is little wonder that Wright subscribes to competitive responsibility versus the prospect of Trump's proposed agenda since the 2016 primaries. In the meantime, Wright surely cringes as he watches foreign policy developments since the new president took office.

This reviewer believes that Wright has accurately appraised the current U.S. foreign policy dilemma. Further, his proposal for responsible competition is probably the best we can do for now. In the meantime, Wright likely feels increased angst watching the Trump administration's foreign affairs to date. Discouragingly, hope for the better is in short supply. For those to whom it matters, Wright's credentials make his words carry weight. He holds a prestigious position with the Brookings Institution and has degrees or affiliations with Cambridge, Harvard, Princeton, Yale, and the University of Chicago. He is also a native of Ireland and began his academic career at the University of Dublin, which gives him unique insight into the geopolitics of Europe.

Wright's message prompts recollection of the often-quoted observation that "those who do not know history are doomed to repeat it." Wise counsel for sure, but in contrast to such wisdom, and in looking at world affairs over the last two years, it seems that today's upside-down world dictates an unhappier corollary, such as "those who know history and ignore it are destined to repeat it anyway." Additionally, the reader should ponder the origin of liberal globalism and that, however precariously, it has kept the world from self-destruction.

Lastly, All Measures Short of War manifests one glaring omission-the ArabIsraeli conflict. Persisting since the post-World War I period, this is certainly among the most vexing of American policy issues. Since 1948, the United States has steadfastly supported Israel. However, in the years after the Six-Day War in 1967, Israel's assertive and aggressive defensive posture has endlessly complicated things. One can only speculate why Wright avoids this vastly important issue, but it certainly belongs in his book. After all, several U.S. presidents have tried and failed to ameliorate this conundrum. Nevertheless, Wright's book is still a major contribution to comprehension of the world we live in, where it is headed, and how to cope with the inevitable.

Frank X. Kozlowski, PhD

Independent historian

Coercion: The Power to Hurt in International Politics. Edited by Kelly M. Greenhill and Peter Krause. New York: Oxford University Press, 2018. Pp. 384. $\$ 105.00$ (hardcover); \$41.95 (paperback). 
Coercion: The Power to Hurt in International Politics, edited by Kelly M. Greenhill and Peter Krause, takes on the daunting task of reexamining and applying anew the fundamental concept of coercion. Coercion, as most readers will know, is "the ability to get an actor - a state, the leader of a state, a terrorist group, a transnational or international organization, a private actor-to do something it does not want to do" (p. 4). Coercion thus includes both deterrence and compellence. The essays in this volume address well-established, if not fully understood, concepts and theories on coercion as well as more contemporary topics, such as migration, that push those concepts into new areas. In these pages, readers will find ample assertions, conclusions, data, and approaches to ponder and debate.

The book is divided into 5 parts across 15 chapters, with an introduction and conclusion penned by the editors and contributions from 16 scholars. The heart of the book is laid out on page xi: "Although contemporary coercion frequently features multiple coercers targeting state and nonstate adversaries with non-military instruments of persuasion, most literature on coercion focuses primarily on cases wherein a single state is trying to coerce another single state via traditional military means." Much of the literature on deterrence and compellence emerged out of a then-familiar bipolar, Cold War era-but that era is long gone. The introduction does an excellent job of summarizing three major themes explored in the volume: 1) that coercion in the twenty-first century involves different tools, actors, and mechanisms; 2) that "traditional" coercion can be examined in new ways today; and 3) that there are varieties of methods and viewpoints that can be brought to bear on coercion.

The organization of the book is logical and clear. The collection introduces the concepts of coercion in chapters 1 and 2; examines the asymmetric world in chapters 3-5; discusses nonstate actors in chapters 6-8; studies new domains and instruments in chapters 9-13; and reexamines continuing problems, such as coercion involving nuclear technology or weapons, in chapters 14 and 15 .

The rationale for the book, as laid out by the editors in the introductory chapter, is to move beyond "traditional premises" of the original literature and capture "fresh theoretical and policy-related developments" (p. xi). They also note that the extant literature is still applicable and useful. The editors write that the book "is intended to connect and synergize scholarship on a broad array of exciting and timely topics and, in the process, help reinvigorate a crucial subfield of security studies and foreign policy" (p. xix). In concluding chapter 1, authors Robert J. Art and Greenhill note three benefits of the collection: applying traditional concepts to new areas, refining coercion-related concepts, and adding new insights (p. 31). One could argue that this ambitious objective is fodder for three separate books, but other research explores coercion in specific ways, so this volume's breadth is rightly a positive. 
Part I consists of two chapters: a review of coercion and an interesting effort to bring "intelligence" into coercive strategies. Chapter 1, by Art and Greenhill, is a fine review of the concept of coercion. Pages 30-31, especially, present a summary of findings of previous literature and some gaps. Moreover, the chapter is well sourced and the footnotes reference many well-known works and ought to be on a reading list for anyone looking for a solid grounding in this topic.

This reviewer identified a missed opportunity to add a subsequent chapter that compares the primary characteristics of the world as it existed when the theories of deterrence and compellence originally blossomed with the world as it exists today. While it is fine to say that international politics in the twentyfirst century is dramatically different, it would be interesting to know how the editors thought that was so. Topics like the information revolution, globalization, and the decentralization of power, along with new ways to think about "power" could have been presented. One could then hypothesize about the mechanisms by which coercion would be effective and ask whether those mechanisms are now different. Signaling, for example, is very important for coercive strategies, both in the past and the present. Is it possible that it was easier in the past? Consider how information was transmitted during the Cuban missile crisis, such as in John F. Kennedy's televised address to the United States or Nikita Khrushchev's letters to Kennedy. Today, there is much more noise and potentially multiple messengers and messages moving in many directions. Perhaps signaling is signaling, however, and it is the content that is important rather than the method of transmission. Likewise, public attitudes toward war or globalization may affect how much risk leaders are willing to take. Thus, a comparison of the Cold War world and the world at present might frame some of the questions or causes of successful coercion raised in the subsequent essays.

In addition, a framework might explain case selection. Although the chapters are organized well, the reasons why certain topics were included in the collection while others were not is not obvious to this reviewer. One of the unexplored topics is information operations-also known as information warfare or influence operations - other than cyber activities, which is the subject of chapter 9. A second is antisatellite weapons. For decades, a country's space assets, including surveillance or communications satellites, were mostly endangered by malfunction or degradation over time. Now, states such as China, which destroyed a satellite in January 2007, or India, which did so more recently in March 2019, can threaten other nations' military and civilian capabilities. Space may be a new domain where coercion might occur.

Chapter 2, by Austin Long, is an engaging attempt to explore the relevance of intelligence in coercion. He argues that accurate intelligence can help a coercer understand its target, consider how the target might react to coercion, 
identify target assets, evaluate the effects of its coercion strategy, and support covert action. There are at least two challenges to studying the role intelligence plays in coercion attempts. First, in some countries, such as the United States, there is a separation between analysts who produce intelligence and decision makers. In this model, the intelligence community does not recommend policy solutions, which are the purview of decision makers who are free to use, misuse, or ignore intelligence, irrespective of the accuracy of it. Therefore, one should examine what the intelligence community knows, what is disseminated to decision makers, and how they use that intelligence. This means breaking open, to some extent, the black box notion of an actor. Second, anyone studying the role of intelligence will invariably run into classification issues with the availability of actual intelligence, especially for events that are more current. The idea of talking about intelligence in the context of coercion is quite interesting and, in this reviewer's opinion, there is more material about the role of intelligence than the author allows. This would be a fruitful area for collaboration between those interested in international politics and those who work in intelligence studies, especially if one could bring together academics and practitioners.

Part II focuses on asymmetry and coercion. In chapter 3, Todd S. Sechser presents a basic model of coercion to examine coercive diplomacy, specifically how coercers choose their demand and the influence of military power on the probability of success. In chapter 4, Phil M. Haun uses a formal model applied to the case of the U.S. response to the 1994 buildup of Iraqi forces along the Kuwaiti border to look at what happens to a powerful actor choosing between a coercing and a brute force strategy. Finally, Alexander B. Downes studies the outcome of efforts to compel foreign leaders to give up power in chapter 6 . All three essays are instructive. An interesting point observed in part II concerns treating actors as unitary. Sechser studies the actions of a coercer and a target, while Haun and Downes examine a challenger and a target. Of course, many analyses do this and produce interesting results, but it would be interesting to break open one of these coercers and their targets to examine the decision makers, the information they used, and their risk calculus. Perhaps this would be neither necessary nor possible in terms of available data in countries such as North Korea, but in other countries such as the United States, this dimension of coercion would seem to be both interesting and instructive. One example in this book that moves in that direction is a chapter by Krause on the Eritrean insurgency, which looks at the impact of intergroup dynamics within the overall national movement.

Part III focuses on nonstate actors. Chapter 6 by Keren E. Fraiman examines the challenge that actors have when trying to coerce a host state to deal with a violent nonstate actor using that state as a base of operations, which the author terms "transitive compellence" (p. 117). Fraiman notes that there have 
been 152 cases of violent nonstate actors using base states from which to stage operations. The author draws on Turkey's efforts to coerce Iraq and Syria to reign in the Kurdistan People's Party to explain the strategy and important characteristics. Chapter 7, by Krause, examines the history of the Eritrean insurgency between 1960 and 1993 to examine how the relative power of groups within the overall movement affects the movement. Finally, returning to the theme of states using coercive strategies against nonstate actors, James Igoe Walsh explores the role of new weapons technologies — specifically armed drones-as a coercive tool. Walsh begins with the assertion that the purpose of drone campaigns "are to compel and deter insurgent and terrorist organizations" (p. 160). This is done by punishing violent organizations, deterring them from committing additional violent acts, and discouraging others from joining or supporting those organizations. The question examined, with reference to the United States' use of drones against insurgents in Pakistan, is whether drones are effective or not. Each of these three chapters deals with topics that are of enduring interest and contemporary relevance and provide much material for discussion.

Part IV examines coercion in new areas aside from the use of overt military force. As seems to be de rigueur in discussions of international relations or security topics, cyber is the theme of chapter 9, written by Jon R. Lindsay and Erik Gartzke. The authors explore an interesting point of whether the stabilityinstability paradox and its logic_— where the threat of mutually assured destruction can deter a full-scale nuclear war but not lower levels of conflict-can also be applied to the cyber realm. In the next chapter, Greenhill examines the fascinating use of migration as a coercion tool. Here, Libya is the case study. Following that, Timothy R. Crawford looks at the idea of "coercive isolation," or the notion of using coercive diplomacy "that reduces a target's expectations of support in a fight” (p. 230). Here, the coercer is after a target state's actual or potential allies. Crawford develops a model of this concept and applies it to six case studies in Europe and Asia, spanning from 1908, when AustriaHungary attempted to coerce Serbia to accept its annexation of Bosnia, to 1989, when China worked to get Vietnam to withdraw from Cambodia. In chapter 12, Daniel W. Drezner tackles a newer topic in the economic sanctions literature-the use of smart sanctions such as financial sanctions against banks doing business with unsavory characters-and delves into the issue of their effectiveness. Finally, Jonathan N. Markowitz looks at the use of coercion over natural resources. These chapters, among others in the book, apply a number of cases that are not about the United States. While the United States is an obvious candidate for initiative coercion against others, and while this book contains several examples of U.S. efforts, the fact that the essays offer cases focusing on other states to apply the logic of coercion to a broad set of actors offers a positive quality. 
Finally, part V, consisting of two chapters, returns to a historical focus of coercion studies: nuclear weapons. Jasen J. Castillo looks at how weak states' acquisition and threats to use nuclear weapons might deter stronger states, while Tristan Volpe looks at how states try to compel concessions from the United States by threatening to proliferate nuclear technology. Castillo examines nuclear weapons states that are outside the U.S. security umbrella: China, India, North Korea, Pakistan, and Russia. Volpe, meanwhile, examines the trajectory of nuclear proliferation, from starting a program to building a weapon. That state can then ask, what is the right amount of nuclear technology to possess? Not too little or too much to credibly threaten to join the nuclear club and coerce states that would prefer that not happen. Examples explored are Saudi Arabia, Iran, North Korea, and Japan.

In sum, the editors sought to speak to "scholars, practitioners, and instructors," and in this they have succeeded (p. xix). The collection is well-organized and well-written. For those interested in coercion in general, the book offers an effective overview of coercion-related topics that scholars are currently dealing with. Readers with specialized interests would also benefit from selected chapters. Like many books, some of the source material is already becoming dated, considering the speed at which some of these topics — such as drone use, cyber, or even efforts to remove foreign leaders-evolve. Fortunately, the essays will provide a solid foundation for scholars seeking to consider additional cases, such as efforts to coerce Venezuelan president Nicolas Maduro to step down. The book, which hopes to reenergize the discussion on coercion, has certainly achieved its goal.

John Sislin, PhD

Teaches intelligence studies with an emphasis on intelligence analysis and collection at the National Intelligence University.

Confronting Torture: Essays on the Ethics, Legality, History, and Psychology of Torture Today. Edited by Scott A. Anderson and Martha C. Nussbaum. Chicago: University of Chicago Press, 2018. Pp. 384. \$105.00 (hardcover); \$35.00 (paperback).

Torture is evil, what ethics and legal scholars call malum in se, or "a wrong in itself." So, why might officials or soldiers torture and think it could serve a good cause? Some in uniform observe that torture arises as retaliation after seeing those beside you killed or abused by the enemy. Interrogations are often a necessity during war, and some individuals go so far as to claim that torture 
during questioning may be required to save lives. Confronting Torture names American officials who approved of and advanced torture in the drive for information about an elusive new enemy capable of mass destruction: al-Qaeda. This book concerns itself with these and further questions. In the best chapter, Christopher J. Einolf makes several fresh observations: "American soldiers have used torture only in counterinsurgency conflicts. . . The nature of counterinsurgency conflict increases the perceived usefulness of torture.... Soldiers often regard insurgent combatants as engaging in illegitimate war tactics, thus apparently providing a moral justification for the use of torture in response" (p. 121).

It seems Einolf is right about the Philippines, where there are accounts of abuse of numerous Filipinos during the American counterinsurgency campaign that began in 1899 . As one example, torture by variants of waterboarding was recognized in theater and was reported in U.S. newspapers, pictorial magazines, and Senate testimony. The Ohio State University owns a 1901 photograph showing the technique. It is also documented in credible histories, such as that by Stuart Creighton Miller. Since the American public saw glimmers of those examples of torture in school or in books at universities, it is remarkable that new mistreatment of prisoners by U.S. agents could surface and be debated after 9/11. That, of course, occurred after the Philippine-American War; after the Geneva Conventions; after the well-known damage France did to itself in Algeria in the 1950s; and after the United Nations Convention Against Torture, which the United States signed in 1988.

The editors and authors of Confronting Torture have a clear position, as their title illustrates. The book's introduction and 14 chapters unfold from that point, discoursing on the history, foreign case studies, legality, ethics, and psychology of torture in a way that is both sober and thought-provoking. It is true that better editing would have yielded a book shorter by a hundred pages, as by cuts within chapters 2,5 , and 9. An additional editing problem is that "torture" is not even defined until chapter 6 .

The virtues of this essay collection start with showing why the committing of torture is an awful idea for any nation in general-even when it seems promising at the moment to an interrogator or their boss. Several authors, especially Marcia Baron, a philosopher at Indiana University, dismantle the misleading, quirky "ticking bomb" hypothesis that took over television shows and too many public discussions. This author made his own list of that scenario's logical problems in Terrorism Today (2008) and finds it good to be considering these authors' fresh angles now. The references and footnotes are of use for anyone wanting a listing of recent law journal articles on the question of torture. A further, somewhat unique virtue of the book may be its section on U.S. police history and a long-past era in which an imaginative range of 
physical techniques of "the third degree" were deployed to "soften up" suspects and loosen their tongues.

That last essay on American police work, written by two Californian professors, is akin to few others in the book in that it will cause some readers to push back, resist generalizations, or seek additional views from practiced police officials, experienced judge advocate generals, or intelligence officers, whether serving or retired. None of those groups have serious representation in these chapters, and their perspectives are missed. This author recalls how, in a National Defense University seminar, several officers sought to say something they thought difficult but honest- that "whatever one hopes for in any classroom, out there in the field, it's common, they torture." Hearing that a second or third time, a Nepalese brigadier spoke up in a voice that had come to have quiet authority during our semester. He advised: "I've found that captives will talk to me. I give them the chance. You'd be surprised how much they talk, when I just sit with them and pour tea." There is encouraging literature, some of it by expert interrogators, who can show the real art in that business when a professional is handling it. Of course, no one pretends to have all the answers, and no one pretends that subjects_-comfortable or not—-may not lie.

Confronting Torture offers some good lines of ethical thinking and ultimately argues that torture is wrong, illegal, and a blunder at the strategic level of war. Such a short summary is not cause to forego the work of thinking, especially when our public forum features such voices as Alan Dershowitz of Harvard University who openly defend torture. Since this debate is as old as man, citizens have to be moral and smart about the matter.

Christopher C. Harmon, PhD

Lead author or editor of six books. Harmon began teaching at Marine Corps University in 1993. Today, he holds the Bren Chair of Great Power Competition.

Dare to Lead: Brave Work, Tough Conversations, Whole Hearts. By Brené Brown. New York: Penguin Random House, 2014. Pp. 320. \$28.00 (hardcover); $\$ 30.00$ (paperback).

"I want live in a world with braver, bolder leaders, and I want to pass that kind of world on to my children. I define a leader as anyone who takes responsibility for finding the potential in people and processes, and who has the courage to develop that potential . . . we desperately need more leaders who are committed to courageous, wholehearted leadership and who are self-aware 
enough to lead from their hearts, rather than unevolved leaders who lead from hurt and fear" (p. 4).

In Dare to Lead, Brené Brown provides engaging descriptions of how leaders can learn the skills to be courageous enough to lead from the heart. Such leaders can brave vulnerability, build trust across their organizations, live up to their values, and have tough conversations that make their organizations and the people therein more resilient. Brown also offers a downloadable workbook to readers that can be used for leader development programs in their own organizations.

As the above excerpt intones, leadership is about maximizing potential. Brown combines research with engaging stories that help leaders gain an understanding of how to maximize the potential of the people and processes in their organizations. This book is for any leader or aspiring leader who wishes to instill in those they lead the ability to overcome shame and reach out to others developing their potential. Dare to Lead may especially interest military professionals who find the pace and magnitude of change in our world increasing exponentially and requiring innovation to meet new challenges. According to Brown, the only way to increase the creativity to adapt to our ever-changing world is to embrace vulnerability. Readers, beware: in Dare to Lead, Brown presents case studies that fly in the face of conventional wisdom regarding how best to lead.

In the book's first section, Brown immediately challenges conventional leadership wisdom by discussing what she calls "rumbling with vulnerability." If asked to describe the classic characteristics of leaders, many readers might include words or phrases such as "aggressive," "take charge," "go getter." Few would include "vulnerable." Brown, however, claims that much of the dysfunction existing in organizations stems from an unwillingness to address feelings of shame, guilt, and inadequacy with which many struggle. To address such challenges, leaders must be willing to become vulnerable enough to have tough conversations that could suggest the idea that they may not have all the answers. Yet, such vulnerable interactions can not only build trust between people but also instill within participants the willingness to take risks, try new things, and recover from failure. In short, embracing vulnerability can assist leaders in developing resilience within the people in their organization, which can further enable creativity, innovation, and adaptation.

The author illustrates the importance of a leader's vulnerability when adapting to new surroundings in a note at the beginning of Dare to Lead that describes her experience speaking to a large group of high-powered business leaders. Feeling intimidated and inadequate, Brown wondered if her discussion of "shame and the dangers of not believing we're enough" would resonate with her audience. To appear more relatable to the audience, she considered inserting business terms into her presentation. Her husband and another presenter, how- 
ever, encouraged her to realize that the audience comprised people like her who, like everyone, deal with shame and feelings of inadequacy. Brown's presentation went very well and provided the inspiration to write Dare to Lead and begin her business, Brave Leaders Inc. Like so many successful leaders, Brown had to overcome feelings of shame and the belief that she might not be enough to step out into something new.

Readers may wonder if they could instill such abilities in people within their organizations. If a leader could increase resiliency within their organization, why wouldn't they? Reading Dare to Lead and using the downloadable curriculum provided offers an outstanding starting point.

Dare to Lead provides a paradigm-breaking view into the world of trust building and resilience that is well-supported by case studies, anecdotes, and research. Although Brown draws from scholarly research, Dare to Lead was written for readers interested in learning how leaders can unlock not only their own potential but also the potential of those around them. This book would definitely serve as a great selection for military professionals who wish to hone leader development skills. An outstanding selection for civilian and military readers alike, Dare to Lead engagingly points the way to innovative resilience by building relationships through trust and vulnerability.

\section{LtCol Richard A. McConnell (Ret)}

Associate Professor, Department of Army Tactics

U.S. Army Command and General Staff College

How NATO Adapts: Strategy and Organization in the Atlantic Alliance since 1950. By Seth A. Johnston. Baltimore: Johns Hopkins University Press, 2016. Pp. 272. \$29.95 (paperback and ebook).

Hastings Ismay, NATO's first secretary general, famously described its tripartite purpose as the ability to "keep the Americans in, the Russians out, and the Germans down" (p. 1). Yet, West Germany became a member a mere six years after the alliance's founding and NATO has survived more than a quarter century since the demise of the Soviet Union (USSR). Of the myriad international organizations established in the wake of World War II, none have proven as nimble.

Seth Johnston, a U.S. Army intelligence officer with an Oxford international relations doctorate, seeks with this volume to explain how. His central argument is that NATO quickly evolved into a true institution whose actors, structures, and processes have ensured its survival and adaptation-sometimes in direct contravention of the desires of its member states. 
While the book is organized chronologically, Johnston is quick to caution that it is not "an exhaustive history of the Alliance, of which there are already several" (p. 5). Still, it contains enough detail for all but the most knowledgeable students of NATO to learn something, going into substantial depth on more than a dozen controversies that sprung up over the first six-plus decades of its history. Special emphasis is given to three inflection points: the Berlin crises, the French withdrawal from the command structure, and the end of the Cold War.

The creation of an integrated military command structure, with World War II hero Dwight Eisenhower as the first Supreme Allied Commander, and the standing up of a permanent staff were the beginnings of institutionalization. Rather than acting simply as a forum where delegates from member states would convene to discuss defense issues, NATO quickly became a missioncentric organization, driven by Eisenhower's vision of actively preparing for the defense of Western Europe. Shortly thereafter, the creation of a civilian secretary general gave the organization an independent political voice as well.

Very early in its existence, NATO had a life of its own as a permanent institution with an instinct for self-preservation quite apart from momentary political considerations in even its most important constituent states. This provided continuity that survived major strains among key member nations, notably the bitter disputes over the Suez Crisis and the Iraq War. Similarly, it was able to endure critical challenges such as Germany's Ostpolitik and even France's withdrawal from the military command structure.

Indeed, most of these fissures forced NATO to address key critiques and often issue revisions to the strategic concept that renewed the alliance to new political and strategic realities. The French departure, for example, forced the sudden exodus of the headquarters from Paris and called into question the very purpose of NATO, but it yielded bigger and better facilities in Belgium and a Future Tasks of the Alliance report that added the diplomatic mission of pursuing détente to the existing military defense mission. This not only set the institution up well for the cooler days of the Cold War that would follow the Cuban Missile Crisis - and, indeed, the eventual end of the Cold War-but also helped cement France's continuing commitment to Article 5.

The fall of the Berlin Wall and the evaporation of the USSR could well have ended NATO. Most member states, and certainly the citizenry thereof, saw its mission as complete. But the existing institutional structures and relationships proved quite useful in dealing with the transition and quickly adapted to new challenges in Europe and beyond.

NATO quickly adopted a new strategic concept that added conflict prevention, crisis management, and cooperation with former rivals to its mission set. Johnston highlights a related development, the Combined Joint Task Force 
concept, which is now so embedded in military doctrine that we might be forgiven for thinking it has always been there. It created a flexible institution that allowed NATO members to fight as coalitions of the willing to deal with security challenges that could not gain universal support, let alone participation, among the ever-expanding membership. It also retained the advantages of NATO's command structure, common operating procedures, and working relationships.

In the short term, NATO became the security institution of choice for dealing with the Yugoslav Wars and the conflict resolution mechanism of choice for crises in the former Soviet space, including in Nagorno-Karabakh, South Ossetia, and Chechnya. Moreover, this period offers the most vivid illustration of Johnston's thesis, as two successive secretaries general facilitated NATO's entry into conflicts despite the reluctance of key allies including the United States, the United Kingdom, France, and Germany. Manfred Wörner engaged in substantial public diplomacy about the United Nations' inadequacy in handling the crisis in Bosnia and continually steered North Atlantic Council (NAC) discussions toward NATO's responsibility to act. He positioned the alliance as the United Nations' (UN) enforcement arm, and the February 1994 shoot down of four Bosnian Serb aircraft in enforcement of the UN's no-fly zone became NATO's first-ever use of force. Two months later, Wörner literally rose from his deathbed to address the NAC, intravenous feeding tubes on full display, and successfully implored them to take an even more active role. Whereas Wörner stepped beyond the customary role of the secretary general in aggressively driving action, his successor, Willy Claes, "used delaying tactics and deliberately withheld his convening powers in order to allow the military campaign to unfold without further political discussion in the NAC" (p. 145). In both cases, NATO manipulated its member states to take actions in the best interest of the organization even though they were politically unpopular.

Beyond that main argument, there are two recurring themes in the book. First, as presaged by Ismay's goal to "keep America in," there has been constant fear by European leaders - and an occasional hint by U.S. leaders - that the United States might decrease its commitment to European security. Johnston notes that during NATO's early years, U.S. strategy required basing substantial numbers of forces in Europe in order to be able to reach the USSR with its bomber fleet. Coupled with the lack of a reciprocal Soviet capability to hit the American homeland, this led to a credible U.S. commitment to European defense. The Soviet development of ICBMs changed that equation drastically, with both superpowers able to hit one another from their own soil and putting the American homeland at risk if it took action against an invasion of Western Europe. NATO dealt with that threat head-on, emphasizing a strategy of forward conventional deterrence with nuclear retaliation a fallback of last resort. 
Second, there has been a constant rise of competing institutions, particularly intra-European alternatives to the trans-Atlantic NATO. Winston Churchill, between terms as prime minister, advocated a unified European Army in 1950. While the idea was far too radical for its time-and remains so even today - variants of the idea have never gone away. Moreover, whereas Churchill saw the move as one that would strengthen the security relationship with the United States by making the military force on his side of the Atlantic more attractive, others, backed by a succession of French presidents, saw it as a hedge against American fecklessness or overreach. As detailed at length by Johnston, these ideas were either defeated outright or substantially neutered not only by the sovereignty concerns of state actors that most international relations scholars have highlighted but also by the deft maneuvering of NATO's leaders and institutions. In some instances, as with the European Defence Council and Western European Union, NATO co-opted its competitors. In others, as with the Common Foreign and Security Policy and its successors, NATO leveraged its first-mover advantage to relegate them to minor players.

How NATO Adapts is the outgrowth of the author's dissertation under the legendary Hew Strachan. As such, it is well-researched and documented, including 34 pages of endnotes. The author relies primarily on official NATO and member state documents, speeches and public statements from NATO and member state officials, interviews and correspondence with NATO bureaucrats and military staff, and a wealth of secondary source material.

There are, alas, pitfalls in publishing a dissertation essentially as-is as a book, given their different purposes. The former is, first and foremost, an exercise in impressing a committee of scholars of one's mastery of independent research skills, which, invariably, comes at the expense of readability. Even though the work is qualitative, there is far more discussion of methodology and research design than necessary, requiring slogging through 35 pages of discursive material before getting on with the topic at hand. Readers unfamiliar with the "congruence method" may be baffled with its mention, which frankly seemed superfluous to understanding the evidence (p. 5).

Similarly, readers are told that the "framework draws on the concept of 'critical junctures' from the literature on historical institutionalism" and assured that this theory has "not been used previously in a major study of NATO, so their use here contributes to knowledge" (p. 11). This is not only irrelevant to most readers but untrue in all but the technical sense. While the keyword "critical juncture" doubtless fails to appear in other studies, it would be next to impossible to write a history or analysis of the alliance without looking at key instances in which leaders faced uncertainty in making major decisions.

Indeed, the obligatory methodological discussion that comprises the second 
chapter concludes with a diagram showing the "possible outcomes" of "NATO critical juncture process" (p. 19). Apparently, when faced with a contingency, there can either be NATO alternatives or non-NATO alternatives. And among the NATO alternatives, NATO can either adapt or remain stable. It's hard to conceive of the reader who did not know that going in.

There are also minor analytic stumbles, such as Johnston's assertion that "in tracing the adaptation of NATO strategy after the Cold War, a prominent feature was NATO's early resistance to change" (p. 135). Literally everything in Johnston's analysis contradicts this. As he superbly documents, NATO's various working groups were feverishly studying the problem by 1989; issued its London Declaration, which recognized fundamental changes in strategy and force structure, in July 1990; and had a new Strategic Concept, completely revamping its mission set, ratified by November 1991. All of this happened before the Soviet Union's demise. Similarly, as Johnston himself points out, the Strategic Concept was revised, in a matter of months after the breakout of the Yugoslav crises, to acknowledge that "the adverse consequences of instabilities" was a greater threat to NATO than "calculated aggression against the territory of Allies" (p. 141). This is a bold embrace, not a resistance, to change.

Still, these are quibbles. Readers who make it through—or better yet, simply skip - the dissertation committee-servicing second and third chapters are rewarded with a cohesive account of the perseverance of the transatlantic alliance. Despite its authorship by a serving officer, the focus on organizational maneuvering and staff processes will likely not appeal to most readers of this journal, who will tend to be more interested in operations, manpower, and the like. But it is essential reading for those of us who study NATO and national security bureaucracy.

James H. Joyner Jr., PhD

Associate professor of strategic studies at the Command and Staff College, Marine Corps University.

State-Building in Kazakbstan: Continuity and Transformation of Informal Institutions. By Dina Sharipova. New York: Lexington Books, 2018. Pp. 190. $\$ 90.00$ (hardcover); $\$ 85.50$ (ebook).

With the creation of the Commonwealth of Independent States in the wake of the collapse of the Soviet Union in 1991, one of the great certainties of Western policy makers was that new Eurasian states would transform into copies 
of democratic-capitalist countries. It was to be a natural, organic process that needed no guidance or assistance. That transformation would be marked by the development of formal structures and institutions establishing rules for the structuring of the social, political, and economic life of the state. The informal rules that bypassed the Soviet system — which author Dina Sharipova describes in her book State-Building in Kazakhstan as clientelism, clans, patronage, informal payments and help, and corruption-were to be abandoned.

However, despite market reforms in Kazakhstan-one of those newly independent states — many old, established, and informal networks remain essential to gaining access to health care, public housing, good paying jobs, and education-all of which the state is unable to provide. Because those networks are so important in the everyday lives of people of Kazakhstan, Sharipova explores the nature and processes of informal reciprocal relationships that are at the heart of them.

Sharipova explains that during the post-Soviet Union period, goods and services became highly decentralized. That, along with state retrenchment, "brought about a more fragmented society and inequality of access to scarce resources" that led to the revival of informal networks (p. xvi). The author explores this condition in three parts. The first provides an examination of informal networks and their function. The second offers a collection of survey data and statistical analysis. The third examines how informal networks function. Sharipova uses health care as a case study, examining conditions that give rise to informal networks and illustrating the process of informal reciprocal exchange that characterizes much of life in Kazakhstan.

"In the context of Kazakhstan, informal institutions are not solely the product of cultural legacies of the pre-Soviet or Soviet periods," the author explains. "Rather, they are also a result of struggles for access to scarce resources in the post-Soviet era" (p. 7). State retrenchment from the social sphere and the decentralization of administrative and financial functions ultimately created the conditions for informal exchanges to develop in Kazakhstan as well as elsewhere in the world. When state capacity is low, informal institutions fill in. Patterns of informality vary greatly depending on what level of social support the state either provides or does not provide. Sharipova's data indicates that "almost every citizen in the country is involved in informal reciprocal exchanges," but not all in the same way (p. 24). Different social groups, economic sectors, and regions all display different patterns and relationships.

Sharipova's closer examination of health care services supports her thesis. Because Kazakhstan endured severe cuts in health care expenditures, informal reciprocal relations developed to compensate for state retrenchment. These alternatives have taken the form of making informal payments or relying on family ties to obtain access to medical care, while health care administrators 
and providers decide how to provide services in a way that financially benefits themselves. That informal structure is supported by entrenched habits of the Soviet era, such as exerting influence, making under-the-table payments, giving gifts, bartering, and falsifying records to gain more resources from the central government as well as to receive rewards and promotions. Sharipova has found that in the post-Soviet period, monetary payments drive informal exchange networks and are perceived as the norm (p. 66). The author's research also indicates that the same informal networks exist for education and housing, as well.

Because the breakdown of government systems has led to widespread corruption and distrust of government, citizens in Kazakhstan are far more willing to use informal systems to get things done, allowing the system to function in a way that benefits the most people. Likewise, informal networks with state employees can open access to state-subsidized housing, largely through monetary exchanges. These networks are dynamic and adapt to changing political and economic conditions. Although there is no longer the issue of scarcity in food and clothing that was common during the Soviet period, Sharipova indicates that, today, "people resort to informal channels to gain quality public goods and services that became scarce in the post-independence period" (p. 127). Goods and services that had been supplied under the Soviet system, such as health care, housing, and education, are now being acquired through monetary payments via informal network exchanges. While the system functions adequately, the state's authority and legitimacy suffers and democratic institutions become harder to develop.

This book offers a model of research and analysis to support a thesis. Although greater comparative analysis with other Central Asian states is needed to confirm her conclusions, Sharipova has introduced an important perspective on the key factors influencing Kazakhstan's political and economic development. Unfortunately, the book reads like an academic report and lacks the stylistic touches that would make it more engaging. Although there is some valuable background information on Soviet structures pertaining to health care, education, and housing, there is no background or summary of the social, political, and economic dynamics of Kazakhstan in the post-Soviet era that help to explain what truly happened in Kazakhstan during its years of transformation. A chapter that offered that kind of background information would help orient the reader to the research problem and thesis as well as provide more context to guide the reader through the analysis.

Nevertheless, Sharipova has accomplished something quite remarkable with State-Building in Kazakhstan. Her well-researched analysis and thoughtful conclusions should widen the perspectives of scholars and diplomats focused on Central Asia and regions formerly belonging to the Soviet Union. The U.S. ambassador to Kazakhstan, as well as the entire country team in the embassy, 
should read this book carefully, for much of the American strategic plan for Kazakhstan — and indeed, all of Central Asia—might be influenced by Sharipova's findings.

Keith D. Dickson, PhD

Professor of military studies at the Joint and Advanced Warfighting School, Joint Forces Staff College, National Defense University. His most recent book is No Surrender: Asymmetric Warfare in the Reconstruction South (2017).

Strategic Challenges in the Baltic Sea Region: Russia, Deterrence, and Reassurance. Edited by Ann-Sofie Dahl. Washington, DC: Georgetown University Press, 2018. Pp. 181. \$98.95 (hardcover); \$32.95 (paperback and ebook).

Political scientist Ann-Sofie Dahl and about a dozen expert academics and seasoned practitioners of national security and defense have offered a comprehensive review of the political and military situation in the Baltic Sea today. This volume presents the North Atlantic Treaty Organization (NATO) and its Nordic partners' concerns about the Putin regime's behavior while offering policy-relevant conclusions and advice. To summarize it in three points: 1) The Russian government's increasingly aggressive moves in the region have destabilized the once-peaceful area of maritime commerce and heightened tensions; 2) NATO remains unprepared for this transformation, especially if it escalates; and 3) the alliance and its partners must develop a long-term strategy to deter further provocations while reassuring Estonia, Latvia, and Lithuania and other European countries, as well.

Dahl has organized the book into three topical parts. The first, "The West, Russia, and Baltic Sea Security" broadly covers the big picture. The second, "NATO Allies and Baltic Sea Security" discusses Baltic, German, Norwegian, and other European perspectives. The third, "NATO's Nordic Partners" highlights Sweden and Finland's points of view. All contributors agree on the nature of the Russian threat. It remains the responses of American and European governments that differ.

Dahl and Anders Fogh Rasmussen, the former secretary general of NATO from 2009 to 2014, summarize the Russian threat in the book's foreword and introduction. Other contributors confirm and further elaborate on that threat in subsequent chapters. Moscow's interests in the Baltic Sea remain political, military, and commercial. The region represents a potential choke point for Russian exports and has thus become vital to the Kremlin's energy policy. The Putin regime has become ever more menacing there, deploying, for example, 
Iskander-M short-range ballistic missiles in Kaliningrad; breaching Finnish and Swedish airspace to simulate nuclear attacks; and occupying part of Eastern Ukraine in 2014.

All this and more-including Russian interference in the American presidential election in 2016 and cyberattacks in the United States and elsewherehas happened within a larger context. Dahl describes it as "a grand-scale challenge to the existing world order as we know it." Moscow's objective remains "to undermine the role of the United States - in Europe and globally - in order to bring American global power and what remains of the unipolar system to a definite end" (p. 2). As Gudrun Persson, a specialist in Russian strategy, phrases it, Vladimir Putin has rejected the post-Cold War liberal international order while moving very purposefully "to create a global order run by the great powers" (p. 27). The alternative international system Putin appears to have in mind remains an authoritarian one with the division of the world into separate spheres of influence. It has much in common with the Peace of Westphalia of 1648; the Vienna Congress of 1815; and the Yalta conference in 1945, where U.S. president Franklin Roosevelt envisioned the United States, Britain, the Soviet Union (USSR), and China as the world's four policemen.

Putin's objectives derive from his take on post-Cold War international affairs. His government has interpreted events from the collapse of Communism in Eastern Europe and the fall of the USSR to the demise of Colonel Muammar Gaddafi in Libya quite cynically. For instance, Russia perceived the Arab uprisings against Gaddafi and other authoritarian governments in the Middle East as part of a carefully planned and well-implemented Western campaign that manipulated news information and social media while using mass protests, backed by military intervention when necessary, to bring about regime change. Thus, from Moscow's perspective, Russia's cyber and hybrid warfare operations; its use of propaganda; and its actions in Ukraine, Syria, and elsewhere merely respond to the ongoing campaign against it and other authoritarian regimes. Putin seems to believe that he is fighting fire with fire, which seems likely to continue into the foreseeable future.

NATO members' responses have varied. Fogh Rasmussen, NATO deputy assistant secretary-general Jamie Shea, and Georgetown University professor Robert Lieber all highlight the importance of the United States' commitment to the alliance, particularly collective defense, as articulated in Article 5. But Washington's support has wavered since the inauguration of Trump, whose nationalism and unfriendliness, at least in rhetoric, toward NATO and the European Union partly reflect a larger public that remains unaware of the alliance's role in transatlantic affairs and its relevance to American security interests in such places as the Middle East.

Across the Atlantic, the Norwegian government's defense posture has 
evolved from focusing on potential conventional crises along its Arctic coast and regarding the Baltic Sea as peripheral, as it did in the 1990s and early 2000s, to a revised strategy that prioritizes supporting the Baltic nations while sending a clear and unequivocal message to the Putin regime that Estonia, Latvia, and Lithuania are under NATO's protection. German policy makers did not pay much attention to the Baltic Sea before Ukraine, either. Although Berlin has started to incorporate the region into its defense posture, it is doing so rather slowly while hoping to balance both détente and deterrence. Germans, like their Swedish and Finnish neighbors, appear to be dealing with a classic security dilemma and would like to avoid escalation. Indeed, Moscow has explicitly warned Stockholm that should Sweden join NATO, Russia would regard it as "a threat" that it "would need to eliminate" (p. 131).

Notwithstanding these varying responses and problems, NATO has begun to change its strategic posture while improving its capabilities on a number of fronts. Most members of the alliance reduced their defense budgets and contributions, particularly with respect to conventional forces, in the 1990s. Many subsequently refocused their efforts on counterterrorism and special operations in out-of-area theaters after 2001.

The Russian incursion into Ukraine in 2014 served as a wake-up call. The Baltic republics have increased their military readiness and lobbied for an enhanced NATO presence in their region since 2014. While NATO has deployed some forces there on a rotating basis, it declined to establish permanent bases there. NATO, Sweden, and Finland have also cultivated close, cooperative relations in anticipation of a possible Russian military incursion in the region and developed a joint response to it. The alliance has also formed a new intelligence capability aimed at analyzing and countering Moscow's cyber and hybrid warfare operations.

Danish political scientist Mikkel Vedby Rasmussen urges NATO to do even more than this. He writes that the alliance has given too much attention to cybersecurity and hybrid warfare and has consequently failed to address the conventional issues the situation raises, particularly with respect to naval operations in the Baltic Sea. Russia, with its geographical advantages and its apparent high state of readiness, has an ability to deny access to NATO forces in the Baltic Sea region, thus complicating not only the alliance's ability to fight there but also its capacity to maintain communications and supply lines, as well. This would ultimately weaken NATO's effectiveness in Estonia, Latvia, and Lithuania in the event of war. Vedby Rasmussen suggests that NATO create a standing naval command in the region, one sufficient to impose a blockade and make the sea hostile to Moscow's aircraft and warships. All contributors agree that the alliance remains in a relatively weak position vis-à-vis Russia in the Baltic Sea region today. 
This Kennan-esque book should be required reading for policy makers; military officers; those who study politics and security in the North Atlantic; and the informed public in the United States, Canada, and Europe. It nicely surveys the threat that Russia poses to the Baltic Sea region and the larger liberal international order and thoroughly discusses NATO's varying responses. For the American public, it would help answer questions about NATO's importance while featuring a range of non-American voices that remain concerned about Moscow's behavior. The book, however, may have a short shelf life, since it remains centered on the post-Ukrainian situation and national strategies and defense postures published through 2017. As a result, it could become less relevant as events continue to unfold, especially after whatever it may be that Putin does next. But this does not detract from its value today.

This reviewer sees only one minor issue. Some contributors refer to a "new Cold War." But the Putin regime, no matter how we characterize its worldview, policies, and actions, represents a problem of considerably less magnitude than the Soviet Union, whose armies controlled Eastern Europe all the way to Berlin. Putin lacks his Communist predecessors' messianic, Marxist-Leninist zeal, not to mention scores of Communist parties and revolutionary movements that answered to the Comintern all over the world. His politics will not likely appeal to anyone other than his fellow authoritarians and his home audience. We should discuss Russia in its twenty-first century, not its twentieth-century framework. Terms like "new Cold War" hinder our ability to do this.

James Lockhart, PhD

Assistant professor of history at Zayad University in the United Arab Emirates. His first book, Chile, the CIA and the Cold War (2019), reevaluates Chile's Cold War experience from a multiarchival, transatlantic perspective. 
